UNIVERSIDADE DE SÃO PAULO

ESCOLA DE ENGENHARIA DE SÃO CARLOS

DEPARTAMENTO DE TRANSPORTES

\title{
UM MODELO PARA ANÁLISE DA COMPATIBILIDADE DE TRÁFEGO ENTRE UM CAMINHÃO OU UMA COMBINAÇÃO DE VEÍCULOS DE CARGA E UM TRECHO DE RODOVIA
}

LEANDRO PUGLIESI DE SOUZA

Dissertação apresentada à Escola de Engenharia de São Carlos da Universidade de São Paulo, como parte dos requisitos para obtenção do título de mestre em Engenharia de Transportes.

ORIENTADOR: Prof. Dr. João Alexandre Widmer

São Carlos

2009 
AUTORIZO A REPRODUÇÃO E DIVULGAÇÃO TOTAL OU PARCIAL DESTE TRABALHO, POR QUALQUER MEIO CONVENCIONAL OU ELETRÔNICO, PARA FINS DE ESTUDO E PESQUISA, DESDE QUE CITADA A FONTE.

Ficha catalográfica preparada pela Seção de Tratamento da Informação do Serviço de Biblioteca - EESC/USP

Souza, Leandro Pugliesi

Um modelo para análise da compatibilidade de tráfego entre um caminhão ou uma combinação de veículos de carga e um trecho de rodovia / Leandro Pugliesi Souza; orientador João Alexandre Widmer. -- São Carlos, 2009.

Dissertação (Mestrado-Programa de Pós-Graduação em Engenharia de Transportes e Área de Concentração em Planejamento e Operação de Sistemas de Transporte) - Escola de Engenharia de São Carlos da Universidade de São Paulo, 2009.

1. Caminhões. 2. Combinação de veículos de carga. 3. CVC. 4. Compatibilidade de tráfego. 5. Rodovia. 6. Simulação. 7. Título. 
FOLHA DE JULGAMENTO

Candidato: Engenheiro LEANDRO PUGLIESI DE SOUZA

Dissertação defendida e julgada em 28.8.2009 perante a Comissão Julgadora:

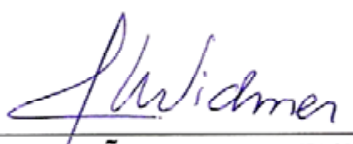

Prof. Titular JOÃO ALEXANDRE WIDMER (Orientador) (Escola de Engenharia de São Carlos/USP)

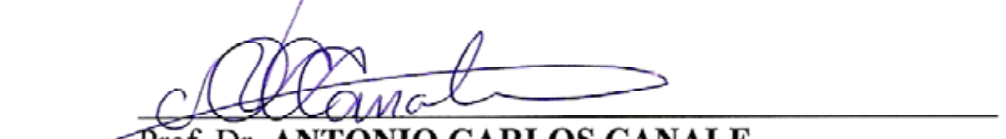

Prof. Dr. ANTONIO CARLOS CANALE (Escola de Engenharia de São Carlos/USP)

Ana Paula ל. Larouca

Prof $^{\mathrm{a}}$. Dr ${ }^{\mathrm{a}}$. ANA PAULA CAMARGO LAROCCA (Escola Politécnica/USP)
Aprovado

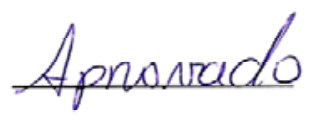

Aprovodo

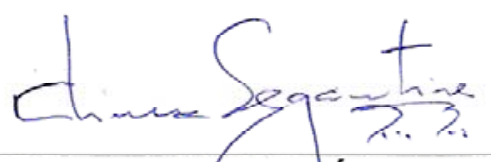

Prof. Associado PAULO CÉSAR LIMA SEGANTINE

Coordenador do Programa de Pós-Graduação em Engenharia de Transportes

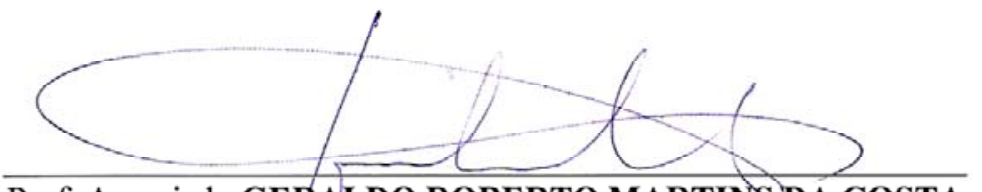

Prof. Associado GERALDO ROBERTO MARTINS DA COSTA Presidente da Comissão da Pós-Graduação da EESC 


\section{DEDICATÓRIA}




\section{AGRADECIMENTOS}

Aos meus pais, Sergio e Sirlene, minha irmã Ligia, pela paciência, amor, dedicação e cooperação durante toda minha vida e formação acadêmica.

Ao Prof. Widmer, pela confiança, incentivo e entusiasmo com que encoraja seus alunos e orientados do departamento de transportes da Escola de Engenharia de São Carlos.

Aos professores Schaal, Leomar, Eiji, Manoel, Parreira, Coca e Setti, pelo incentivo, conhecimento e lições transmitidas a nós alunos e pesquisadores do STT.

Aos amigos e alunos do STT, pelo acolhimento e amizade, fundamentais para o desenvolvimento deste trabalho, em especial: André, Bruno, Caio, Cynthia, Diogo, Jorge, Leonardo, Matheus, Vanessa e Waldemiro. A Sra. Magali, que transforma o departamento em verdadeiro lar para nós alunos.

Aos amigos de outras tantas jornadas, Saulo, Diego, Diego Luiz, Fernanda e Beatriz, responsáveis por transformar momentos de incertezas em boas conversas e descontração, restituindo a força para várias retomadas ao trabalho e conclusão desta dissertação. 


\section{SUMÁRIO}

DEDICATÓRIA

AGRADECIMENTOS

SUMÁRIO

LISTA DE FIGURAS

LISTA DE TABELAS

LISTA DE ABREVIATURAS E SIGLAS

LISTA DE SÍMBOLOS

RESUMO

ABSTRACT xiv

1. INTRODUÇÃO

1.1. Justificativa 4

1.2. Objetivo 6

1.3. Estrutura do trabalho 7

2. REVISÃO BIBLIOGRÁFICA

2.1. Tração 10

2.2. Frenagem motora 22

2.3. Frenagem de emergência 27

2.4. Sobrelargura 35

2.5. Estabilidade e controle 44

2.6. Comportamento do condutor 52

2.7. Consumo de combustível e emissões de poluentes 54

3. MÉTODO

3.1. Construção do simulador SimVC 66

3.2. Verificação do algoritmo 71

3.3. Análise complementar 85

4. ANÁLISES DE COMPATIBILIDADE

4.1. Veículos compatíveis com um trecho de rodovia 88

4.2. Outros estudos de compatibilidade 98

5. CONCLUSÃO 
6. REFERÊNCIAS BIBLIOGRÁFICAS 106

ANEXO A - Lista de variáveis do simulador 118

ANEXO B - Algoritmos das macros 119

ANEXO C - Manual do usuário 130

ANEXO D - Verificação da acurácia do algoritmo 140

APÊNDICE I - Tabelas 145 


\section{LISTA DE FIGURAS}

Figura 1: Distribuição da relação potência/massa para caminhões (Adaptado de Cunha, 2007). 2

Figura 2: Quantidade de AETs expedidas - SIAET (DNIT, 2007) ............................... 5

Figura 3: Áreas de aplicação dos modelos de desempenho veicular. ............................. 7

Figura 4: Curvas de desempenho para veículos com $200 \mathrm{lb} / \mathrm{hp}$, aproximadamente 11cv/t

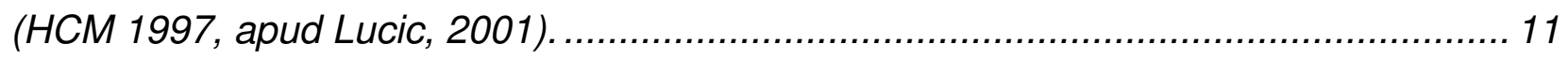

Figura 5: Esquema de forças agindo sobre um veículo em movimento. ...................... 12

Figura 6: Curvas de potência máxima, torque e consumo específico contra rotação do

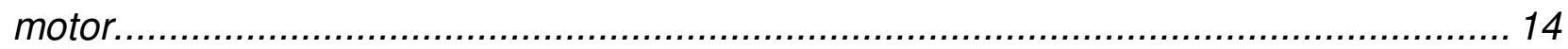

Figura 7: Curvas de tração e resistência ao movimento............................................. 17

Figura 8: Estrutura do simulador de tração............................................................ 18

Figura 9: Exemplo de Carta de Retardação (Canale et al, 2005)................................ 26

Figura 10: Escorregamento em função da força de frenagem (Viana (2006), apud

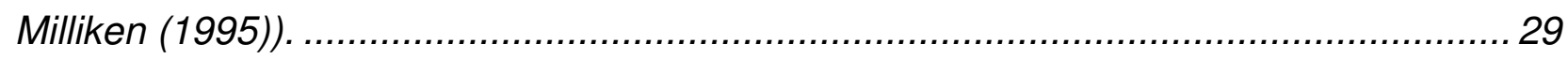

Figura 11: Elipse de Aderência (Canale, 1998). ................................................... 30

Figura 12: Coeficiente de atrito em função do escorregamento parcial na frenagem

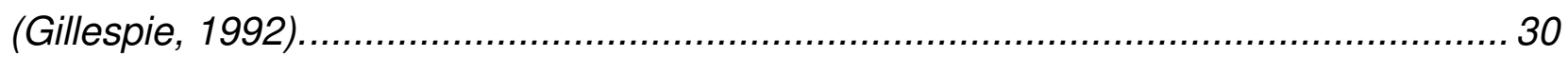

Figura 13: Distâncias de visibilidade e parada $\left(t_{r}=2,5 s ; h_{f}=0,60 ; f=0,30\right)$.................... 33

Figura 14: Articulações A, B e C-Dolly, entre veículos de carga.................................. 36

Figura 15: Trajetória em regime permanente (adaptado de Fancher \& Mathew, 1987) . 37

Figura 16: Arraste em função do raio da curva $(W B=5 m ; H T=1,25 m)$......................... 39

Figura 17: Construção da curva tractrix............................................................... 40

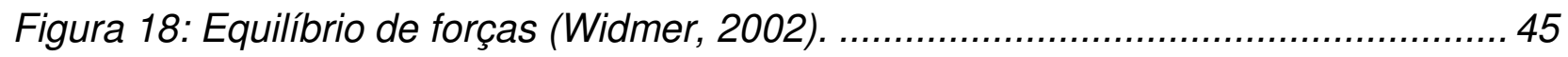

Figura 19: Passeio do c.g. longitudinal de um semi-reboque (adaptado de FERNANDES, 1994)

Figura 20: Modelo da bicicleta para estabilidade (Horta Gutierrez, 1999)..................... 48

Figura 21: Modelo com três graus de liberdade para estabilidade (adaptado de Segel,

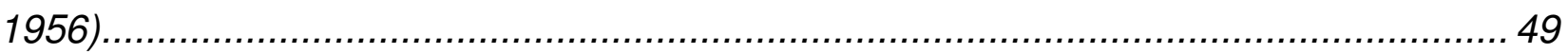

Figura 22: Taxa de emissão de poluentes e consumo de combustível (Ahn, 1998).......62

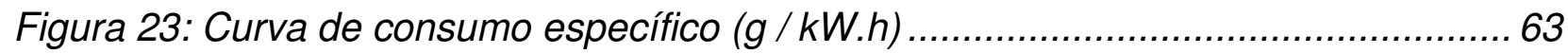

Figura 24: Mapa de consumo específico de um motor (Ahn, 1998) ............................. 64 
Figura 25: Relações de dependência entre modelos

Figura 26: Fluxograma do funcionamento de SimVC................................................. 70

Figura 27: Erro Médio Absoluto (EMA) por categoria de veículo (Cunha, 2007)............ 72

Figura 28: Curvas de aceleração e desaceleração de SimVC para veículo com 11cv/t .74

Figura 29: Comparação entre perfil de velocidades: Truper $x$ SimVC..........................77

Figura 30: Perfis de velocidade coletados ao longo de rodovia de pista dupla ................ 79

Figura 31: Perfis de velocidades obtidos nas simulações ..........................................80

Figura 32: Simulações com limitação de velocidade de $90 \mathrm{~km} / \mathrm{h}$.................................. 80

Figura 33: Simulações com interferência do condutor ............................................. 81

Figura 34: Inclinações do perfil vertical ao longo do trecho (Lucic, 2001) .......................82

Figura 35: Dados coletados e curva simulada (PBTC 25t)...........................................83

Figura 36: Dados coletados e curva simulada (PBTC 44t)...................................... 83

Figura 37: Perfil de velocidades para veículos sem carga ….....................................90

Figura 38: Perfil de velocidades para veículos com carga …......................................91

Figura 39: Índice de acidentes e variação da diferença de velocidade média [mph] de automóveis e caminhões (Melo, 2002 apud. Solomon, 1964)...................................93

Figura 40: Trecho crítico: veículos sem carga (a) e com carga (b) ...............................94

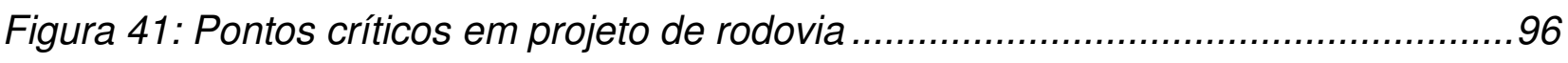

Figura 42: Exemplo de curva gerada pelo AutoTurn (Freitas, 2009)............................99

Figura 43: Fluxograma do algoritmo de tração.....................................................119

Figura 44: Fluxograma do algoritmo de cálculos estáticos........................................126

Figura 45: Interface - SimVC (Simulador de Veículos de Carga) .............................. 133

Figura 46: Caixa de edição - caminhão/CVC ........................................................... 134

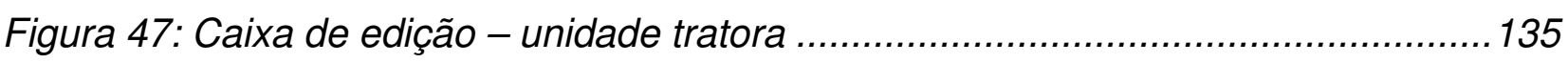

Figura 48: Caixa de edição - pneumáticos e sistema de freios .................................. 135

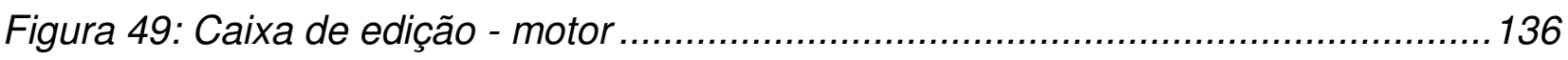

Figura 50: Caixa de edição - caixa de mudanças................................................ 136

Figura 51: Caixa de edição - diferencial ............................................................... 137

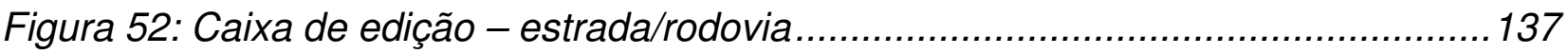

Figura 53: Caixa de edição - condutor/motorista.................................................. 138

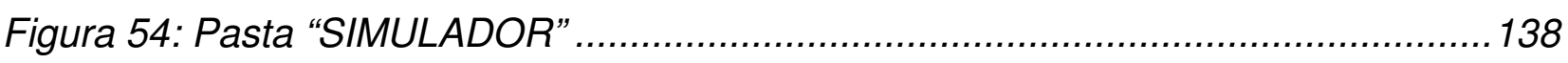

Figura 55: Perfil de velocidades: curvas de aceleração e desaceleração ......................141

Figura 56: Perfil de velocidades: SimVC e Truper .................................................... 142 
Figura 57: Perfil de velocidades: simulação (SP-310) 143

Figura 58: Perfil de rotações: simulação (SP-310) 144

Figura 59: Diâmetro dinâmico do pneumático .... 148

Figura 60: Freio motor e retarders (CANALE \& GUTIÉRREZ, 2005) 149 


\section{LISTA DE TABELAS}

Tabela 1: Pesos e dimensões permitidos em alguns países (Nagl (2007) e Resolução 210 do CONTRAN (BRASIL, 2006a)).

Tabela 2: Compatibilidade das sobrelarguras em curvas horizontais considerando as simulações de alguns veículos de projeto (Pereira Neto, 2007) ..................................42

Tabela 3: Exemplos de combinações de veículos de carga (Widmer, 2008)..................44

Tabela 4: Poluentes e suas implicações ..............................................................54

Tabela 5: Fatores que afetam consumo de combustível.............................................57

Tabela 6: Parâmetros usados no modelo de desempenho (Melo, 2002)........................71

Tabela 7: Características dos veículos simulados....................................................... 76

Tabela 8: Característica dos veículos utilizados na coleta de dados ........................... 78

Tabela 9: Características dos veículos simulados................................................... 79

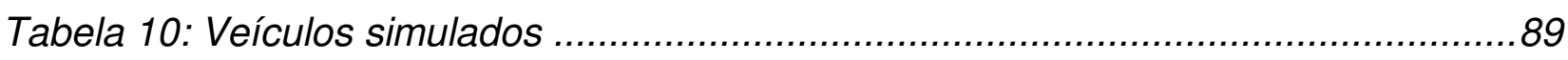

Tabela 11: Potência de frenagem motora requerida pela Resolução no $777 / 93$ …...........98

Tabela 12: Lista de variáveis do simulador ..............................................................118

Tabela 13: Dados armazenados na pasta MCVC ……........................................130

Tabela 14: Dados armazenados na pasta MCAM................................................131

Tabela 15: Parâmetros utilizados nas simulações feitas por Lucic, 2001 .................... 140

Tabela 16: Coeficientes de atrito (Cr) para superfícies de rodovias (Fith, 1994) ..........145

Tabela 17: Coeficientes de atrito (C2 e C3) para pneumáticos (Fith, 1994)..................145

Tabela 18: Coeficientes de atrito em função da velocidade ...................................... 146

Tabela 19: Fator de atrito lateral $f_{\text {máx }}$ adotado no projeto de curvas horizontais (Pereira

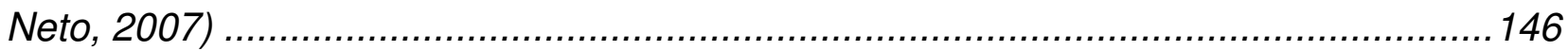

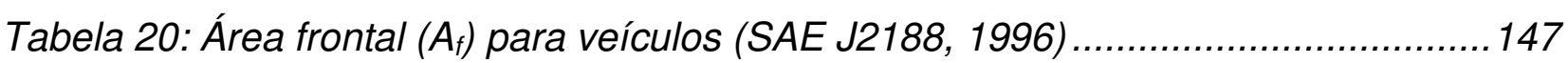

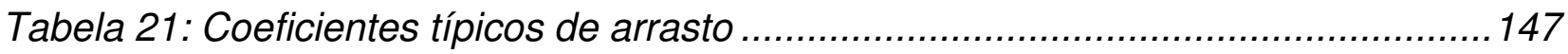

Tabela 22: Nomenclatura para pneumáticos........................................................ 148 


\section{LISTA DE ABREVIATURAS E SIGLAS}

\begin{tabular}{|c|c|}
\hline AASHTO & - American Association on Highway Transportation \\
\hline ABNT & - Associação Brasileira de Normas Técnicas \\
\hline ABS & - Antilock Brake System \\
\hline AET & - Autorização Especial de Trânsito \\
\hline AUSTROADS & - Australian and New Zealand Road Transport and Traffic Authorities \\
\hline c.g. & - Centro de gravidade \\
\hline CMT & - Capacidade Máxima de Tração \\
\hline CNT & - Confederação Nacional de Trânsito \\
\hline CONTRAN & - Conselho Nacional de Trânsito \\
\hline CVC & - Combinação de Veículos de Carga \\
\hline DENATRAN & - Departamento Nacional de Trânsito \\
\hline DNER & - Departamento Nacional de Estradas de Rodagem \\
\hline DNIT & - Departamento Nacional de Infra-Estrutura em Transportes \\
\hline ECE & - Economics Community European \\
\hline EEC & - European Economic Community \\
\hline GPS & - Global Positioning System \\
\hline $\mathrm{HCM}$ & - Highway Capacity Manual \\
\hline INMETRO & - Instituto Nacional de Metrologia \\
\hline ITS & - Inteligent Transportation System \\
\hline NBR & - Norma Brasileira \\
\hline PBT & - Peso Bruto Total \\
\hline PBTC & - Peso Bruto Total Combinado \\
\hline SAE & - Society of Automotive Engineers \\
\hline TAC & - Transportation Association of Canada \\
\hline
\end{tabular}




\section{LISTA DE SÍMBOLOS}

$\mathrm{a}=$ aceleração $\left(\mathrm{m} / \mathrm{s}^{2}\right)$

$\mathrm{ac}_{\max }=$ aceleração lateral limite de tombamento $\left(\mathrm{m} / \mathrm{s}^{2}\right)$

$\alpha=$ consumo inerente ao movimento $(\mathrm{ml} / \mathrm{s})$

$\alpha_{i}=$ aceleração ao redor do eixo i $\left(\mathrm{m} / \mathrm{s}^{2}\right)$

$A_{f}=$ área frontal do veículo $\left(\mathrm{m}^{2}\right)$

$\mathrm{b}=$ distância entre eixos do veículo $(\mathrm{m})$

$\beta=$ parâmetro dependente dos tempos de ignição, bloqueios na entrada de ar, e outros

parâmetros $(\mathrm{ml} / \mathrm{s} . \mathrm{kW})$

$\mathrm{C}=$ calor específico do material das panelas de freio $\left(\mathrm{J} / \mathrm{kg}^{\star}\right.$ Kelvin$)$

$\mathrm{C}_{1}=$ densidade do ar ao nível do mar e temperatura de $15 \stackrel{\circ}{ } \mathrm{C}$

$\mathrm{C}_{2}=$ coeficiente para 0 tipo de pneumático

$\mathrm{C}_{3}=$ coeficiente para o tipo de pneumático e outros fatores

$\mathrm{C}_{\mathrm{d}}=$ coeficiente de arrasto

$\mathrm{C}_{\mathrm{r}}=$ coeficiente para condições da superfície de rolamento

$\mathrm{C}_{\mathrm{h}}=$ coeficiente para altitude

Consumo Instantâneo $=$ taxa de consumo instantânea $(\mathrm{g} / \mathrm{h})$

Consumo $_{\text {específico }}=$ consumo específico do motor do veículo $(\mathrm{g} / \mathrm{kW} . \mathrm{h})$

$\mathrm{D}=$ distância de visibilidade e parada $(\mathrm{m})$

$\mathrm{D} 1$ = distância percorrida durante o tempo de reação $(\mathrm{m})$

$\mathrm{D} 2$ = distância de frenagem $(\mathrm{m})$

$\Delta \mathrm{t}=$ incremento de tempo $(\mathrm{h})$

$\Delta T=$ variação da temperatura no conjunto de freio ( ${ }^{\circ} \mathrm{C}$ ou Kelvin)

$E_{i}=i$-ésima distância entre pontos notáveis do veículo $(m)$

$e_{\max }=$ superelevação máxima da curva (\%)

$f=$ coeficiente de atrito pneu-pavimento

$f_{\text {lateral }}=$ fator de atrito lateral máximo admissível

$f_{\text {vel }}=$ fator de atrito, estabelecido para velocidade considerada

$\mathrm{F}=$ consumo instantâneo $(\mathrm{ml} / \mathrm{s})$

$\mathrm{F}_{\mathrm{t}}=$ força de tração nos pneumáticos $(\mathrm{N})$

$\mathrm{F}_{\text {tração,atrito }}=$ força máxima de tração devida ao atrito $(\mathrm{N})$ 
$\mathrm{F}_{\text {tração,motor }}=$ força máxima de tração devida ao motor $(\mathrm{N})$

$F_{r}=$ força na roda $(\mathrm{kgf})$

$\phi_{\mathrm{d}}=$ diâmetro dinâmico do pneumático $(\mathrm{m})$

$\mathrm{g}=$ aceleração da gravidade $\left(\mathrm{m} / \mathrm{s}^{2}\right)$

$g_{d}=$ relação de redução no diferencial

$\mathrm{g}_{\mathrm{t}}=$ relação de redução na caixa de mudanças

$\mathrm{G}=$ peso bruto total combinado $(\mathrm{t})$

$\mathrm{G}_{\mathrm{C}}=$ gabarito estático do veículo de projeto em curva $(\mathrm{m})$

$\eta$ = eficiência da transmissão da força gerada no motor aos eixos tratores

$\eta_{\mathfrak{f}}=$ rendimento do sistema de freios do veículo

$\mathrm{h}=$ altura do centro de gravidade do veículo $(\mathrm{m})$

$\mathrm{H}=$ altitude $(\mathrm{m})$

HL1 = excentricidade do pino rei, distância entre a suspensão traseira do cavalo mecâ-

nico e a articulação $(m)$

$\mathrm{HT}=$ metade da medida da bitola do eixo dianteiro $(\mathrm{m})$

$\mathrm{I}=$ momento de inércia $\left(\mathrm{m}^{4}\right)$

$\mathrm{i}=$ inclinação da pista $(\mathrm{m} / \mathrm{m}$ ou \%)

$\mathrm{i}_{\max }=$ inclinação máxima de pista $(\mathrm{m} / \mathrm{m}$ ou \%)

ic $=$ maior relação de redução na caixa de câmbio, $1^{\text {a }}$ marcha

id = relação de redução no eixo traseiro

$\mathrm{L}=$ deslocamento ou espaço percorrido pelo veículo $(\mathrm{m})$

$L_{v}=$ largura física do veículo de projeto $(\mathrm{m})$

$L_{i, j}^{e}, M_{i, j}^{e}=$ coeficiente para velocidade "i" e aceleração " $\mathrm{j}$ "

$M O E_{e}=$ emissão instantânea $(\mathrm{mg} / \mathrm{s})$

$\mu$ ou $u$ = coeficiente de atrito longitudinal ( $u$ é a notação adotada pelo DNIT)

$\mathrm{M}=$ massa do veículo $(\mathrm{kg})$

$\mathrm{n}=$ número de segmentos notáveis da composição

$\mathrm{n}_{\text {faixas }}=$ número de faixas de tráfego

$\mathrm{N}$ = número de rotações por minuto no vira-brequim (rpm)

$\mathrm{OT}_{\text {máx }}=$ arraste máximo constante $(\mathrm{m})$

$\mathrm{P}=$ potência fornecida pelo motor $(\mathrm{kW})$

$P_{B}=$ potência dissipada pelo sistema de freios (watts) 
$\mathrm{P}_{\mathrm{BM}}=$ potência dissipada pelo freio motor (watts)

$\mathrm{P}_{\mathrm{c}}=$ potência total durante viagem com velocidade constante $(\mathrm{kW})$

$\mathrm{P}_{\mathrm{a}}=$ potência relativa à inércia do veículo $(\mathrm{kW})$

$P_{D}, P_{I}=$ potências associadas à inércia $(k W)$

$\mathrm{P}_{\mathrm{ec}}, \mathrm{P}_{\mathrm{ea}}=$ potências associadas às resistências internas durante movimento uniforme $\mathrm{e}$ acelerado $(\mathrm{kW})$

$\mathrm{Q}_{\mathrm{B}}=$ quantidade de calor armazenada nos tambores de freios $(\mathrm{J})$

$Q_{M B}=$ quantidade de calor armazenada no freio motor $(\mathrm{J})$

$R$ = soma das forças de resistência ao movimento, $R_{a}, R_{r}, R_{g}(N)$

$\mathrm{R}_{\mathrm{a}}=$ resistência aerodinâmica $(\mathrm{N})$

$\mathrm{R}_{\mathrm{g}}=$ resistência de rampa $(\mathrm{kN})$

$\mathrm{R}_{\mathrm{r}}=$ resistência ao rolamento $(\mathrm{N})$

$R_{c}=$ raio da curva em relação ao centro do eixo dianteiro $(m)$

$\mathrm{R}_{\min }=$ raio mínimo para curva circular $(\mathrm{m})$

$\mathrm{R} 1$ = raio referente ao eixo dianteiro do cavalo mecânico $(\mathrm{m})$

$\mathrm{R} 2$ = raio referente ao eixo traseiro do cavalo mecânico $(\mathrm{m})$

$\mathrm{R} 3$ = raio referente ao eixo traseiro do semireboque $(\mathrm{m})$

$\mathrm{RH} 1$ = raio referente ao pino rei da quinta-roda $(\mathrm{m})$

$\rho=$ densidade do combustível $(0,74 \mathrm{~g} / \mathrm{l}$ a $0,82 \mathrm{~g} / \mathrm{l})$

$\mathrm{s}=$ sobrelargura $(\mathrm{m})$

$\mathrm{t}=$ tempo de utilização do sistema de freios (s)

$\mathrm{t}_{\mathrm{b}}=$ bitola do veículo $(\mathrm{m})$

$\mathrm{T}=$ torque ao redor do eixo (N.m)

$\mathrm{Tm}=$ torque máximo (kgf.m)

$\mathrm{TR}=$ raio da curva em relação à roda dianteira externa $(\mathrm{m})$

$t_{r}=$ tempo de percepção e reação do condutor (s)

$\mathrm{V}=$ velocidade do veículo $(\mathrm{km} / \mathrm{h})$

$\mathrm{W}=$ peso do veículo $(\mathrm{kN})$

WB = distância entre eixos (m)

WB1 = distância entre eixos do cavalo mecânico (m)

WB2 = distância entre eixos do semi-reboque $(\mathrm{m})$

$\mathrm{W}_{\mathrm{dr}}=$ peso do tambor ou disco $(\mathrm{kg})$

$\mathrm{W}_{\mathrm{ta}}=$ força peso aplicada sobre os eixos tratores $(\mathrm{N})$ 


\section{RESUMO}

SOUZA, L.P. Um modelo para análise da compatibilidade de tráfego entre um caminhão ou uma combinação de veículos de carga e um trecho de rodovia. 2009. 148p. Dissertação (Mestrado) - Escola de Engenharia de São Carlos, Universidade de São Paulo, São Carlos, 2009.

Esta pesquisa avalia a aplicabilidade de modelos matemáticos para analisar a compatibilidade de tráfego de caminhões e combinações de veículos de carga com trechos de rodovias. Os modelos avaliados permitiram a elaboração de um simulador de tráfego de veículos rodoviários de carga em trechos de rodovias, permitindo determinar o perfil de velocidades com base nas características mecânicas do veículo e o perfil da rodovia. O método permite ainda obter os valores de aceleração, potência utilizada, e consumo de combustível. Os resultados obtidos mostraram-se consistentes com observações de campo e recomendações de manuais de projeto de rodovias. Outros fatores associados à compatibilidade entre veículos e rodovias, como capacidade de frenagem motora, capacidade de frenagem de emergência, requisitos de sobrelargura, estabilidade veicular, influência do comportamento do condutor sobre as simulações, consumo de combustíveis e emissões de poluentes são discutidos. Conclui-se que o simulador tem utilidade tanto como ferramenta de análise da compatibilidade de tráfego de veículos de carga em trechos de rodovias, como para identificar deficiências de projeto geométrico de rodovias para autorizar o tráfego de determinadas configurações veiculares.

Palavras-chave: caminhões; combinação de veículos de carga; CVC; compatibilidade de tráfego; projeto de rodovia; consistência de projetos; rodovia; simulação 


\begin{abstract}
SOUZA, L.P. A model to analyze the traffic compatibility of trucks or cargo combination vehicles with road segments. 2009. 148p. Dissertação (Mestrado) - Escola de Engenharia de São Carlos, Universidade de São Paulo, São Carlos, 2009.

This research evaluates the applicability of mathematical models to analyze the traffic compatibility of trucks or cargo combination vehicles with road segments. The evaluated models led to a cargo vehicle locomotion simulator along a road segment, that calculates the speed profile of the vehicle as a function of its mechanical characteristics and the road profile. The method also calculates values of acceleration, used power, and fuel consumption. The results obtained are consistent with field observations and recommendations of road design manuals. Others factors associated with the traffic compatibility of cargo vehicles with geometric characteristics of a road segment like engine braking capability, emergency braking capability, overwidht requirements, vehicle stability, conductor influence, fuel consumption, and emissions rates are also discussed. The conclusion is that the simulator can be used as a tool for traffic compatibility analysis of cargo vehicles with road sections or to identify road design deficiencies to certify traffic of certain vehicle configurations.
\end{abstract}

Keywords: trucks; load combination vehicle, LCV; traffic compatibility; road design; consistency design; road; simulation. 


\section{INTRODUÇÃO}

A movimentação de cargas no Brasil é forte dependente do sistema rodoviário de transporte, sendo que dos quase 1.634.071 quilômetros de rodovias no país, apenas $12,95 \%$ são pavimentadas. As rodovias brasileiras são responsáveis por $61,1 \%$ do total de cargas transportadas (CNT, 2009), sendo que a frota de caminhões, conforme pesquisa do DENATRAN ${ }^{1}$ (BRASIL, 2009), em operação sobre esta malha viária é de 2.301.661 caminhões.

Países em desenvolvimento convivem com acelerada evolução tecnológica dos veículos de carga e necessitam de investimentos em infra-estrutura para comportar o advento das novas tecnologias. Esta evolução tecnológica está invariavelmente associada a aumentos na capacidade de carga, no número de eixos, no comprimento das composições, nas velocidades de operação, e em modificações das características mecânicas e estruturais desses veículos. O investimento na malha rodoviária almeja promover acessibilidade e desenvolvimento a regiões com acesso restrito ou limitado a grandes centros urbanos e produtivos. Para que surta o efeito desejado, novos projetos de ampliação e meIhorias da malha devem ser condizentes com os veículos que nela trafegarão.

São variados os tipos de veículos rodoviários de carga em operação no Brasil. Para caracterizar a composição da frota de caminhões e CVCs ${ }^{2}$ Cunha (2007) fez observações em rodovias paulistas de pista dupla e propôs uma classificação para veículos de carga baseada no número de eixos dos veículos, dividindo-os em quatro categorias: leves (2 eixos), médios (3 e 4 eixos), pesados (5 e 6 eixos) e extra-pesados (7 ou mais eixos). A Figura 1 apresenta a freqüência relativa acumulada de cada categoria, em função da relação entre a potência motora e a massa total do veículo.

${ }^{1}$ DENATRAN - Departamento Nacional de Trânsito

${ }^{2}$ CVC - Combinação de Veículos de Carga 


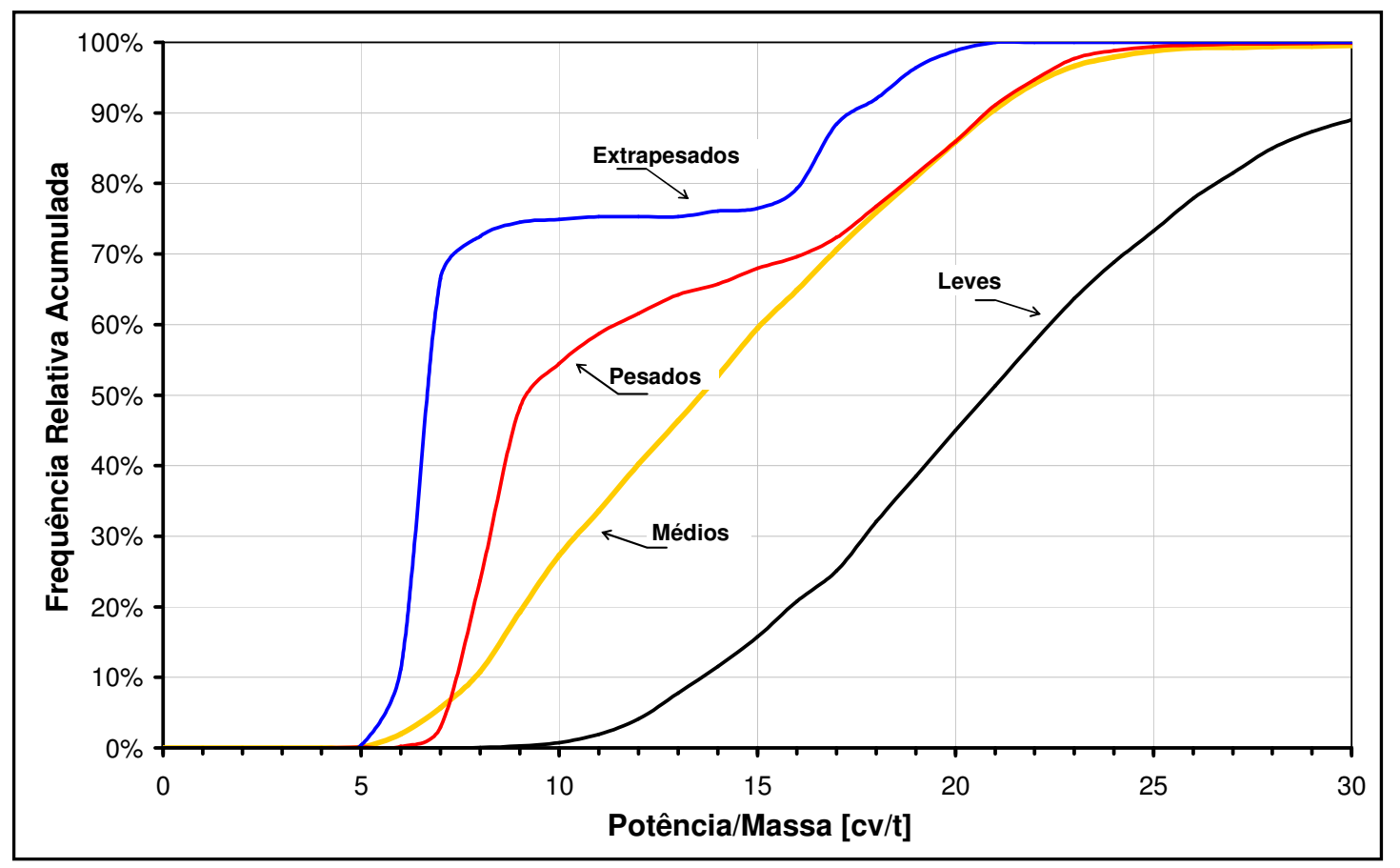

Figura 1: Distribuição da relação potência/massa para caminhões (Adaptado de Cunha, 2007).

Os manuais de projeto de rodovia propostos pelos órgãos governamentais freqüentemente são incompatíveis com as necessidades de veículos pesados e extra-pesados. Não obstante, as rodovias brasileiras apresentam grande heterogeneidade em suas características geométricas, seja devido a diferenças topográficas entre as regiões, a distintas condições naturais de terreno ou a capacidade diferenciada de investimento de cada estado. Uma das conseqüências destas diferenças é a ocorrência de níveis diferentes de restrições que veículos complexos necessitam enfrentar em suas operações.

Tendo em vista a evolução tecnológica acelerada dos veículos rodoviários de carga, a necessidade de expansão da malha rodoviária brasileira, o crescimento do número de veículos pesados e extra-pesados na composição do tráfego, e as diferenças de níveis de restrições ao tráfego para veículos complexos, fica evidente a demanda por estudos de compatibilidade de tráfego entre caminhões, CVCs e rodovias. Da mesma forma, órgãos governamentais necessitam de ferramentas para avaliar tecnicamente se veículos que venham a entrar em 
operação terão condições de trafegar sem causar prejuízos a segurança e fluidez do tráfego (PEREIRA NETO, 2007).

Desta forma, analisar a compatibilidade de tráfego de um veículo pode ser entendido como determinar seu desempenho e interação com a via e demais veículos. É possível classificar os trabalhos desenvolvidos sobre esse tema em quatro grupos, a saber:

1) Desempenho veicular (micro-simulação): considera o veículo numa situação de fluxo livre, cujas restrições ao tráfego são impostas pela via, pelas características mecânicas do próprio veículo e sua condição de carregamento, e pela estratégia de condução.

2) Interferência com o tráfego (macro-simulação): o desempenho do veículo é afetado pelo desempenho e estratégia de condução dos outros veículos e condutores que trafegam na mesma corrente de tráfego (DEMARCHI, 2000; CUNHA, 2007);

3) Danos causados ao pavimento: estuda a deterioração dos pavimentos causada por veículos com diferentes configurações de carga e de eixo. Os danos dependem basicamente do tipo de pneu e calibração, tipo de suspensão, configuração dos eixos, peso por eixo, e composição das camadas do pavimento. (FABBRI et al., 1990; FERNANDES JÚNIOR, 1994);

4) Danos causados à estrutura de pontes e viadutos: avalia o impacto de um veículo sobre a estrutura de obras de arte construídas com diferentes vãos, materiais e sistemas construtivos (DEBS et al, 2004; FERREIRA et al., 2007).

O primeiro grupo apresentado, desempenho veicular, é o foco desse estudo, que avalia a compatibilidade de tráfego entre um caminhão ou uma Combinação de Veículos de Carga e um trecho de rodovia, utilizando para isto modelos matemáticos de micro-simulação desenvolvidos e calibrados por outros pesquisadores. 


\subsection{Justificativa}

A evolução dos veículos não ocorre da mesma forma em todos os países, seja devido a diferenças topográficas, de carga transportada, ou de regulamentação existente. A Tabela 1 apresenta dimensões e pesos máximos permitidos por alguns países.

Tabela 1: Pesos e dimensões permitidos em alguns países (Nagl (2007) e Resolução 210 do CONTRAN (BRASIL, 2006a)).

\begin{tabular}{|c|c|c|c|c|c|}
\hline \multirow{2}{*}{ País } & \multirow{2}{*}{$\begin{array}{l}\text { Peso máx. } \\
\text { por eixo } \\
\text { simples [t] }\end{array}$} & \multirow{2}{*}{$\begin{array}{l}\text { PBTC máxi- } \\
\text { mo [t] }\end{array}$} & \multicolumn{3}{|c|}{ Dimensões máximas [m] } \\
\hline & & & Comprimento & Altura & Largura \\
\hline Austrália & 9,0 & $45,5(125,2)$ & $19,0(53,5)$ & 4,3 & 2,5 \\
\hline Brasil & 10,0 & $57,0(74,0)$ & $19,80(30,0)$ & 4,40 & 2,6 \\
\hline Canadá & 9,1 & 62,5 & $25,0(38,1)$ & 4,12 & 2,6 \\
\hline China & 10,0 & 40,0 & 18,0 & 4,2 & 2,5 \\
\hline Alemanha & 10,0 & 44,0 & 18,75 & 4,0 & 2,6 \\
\hline Índia & 10,2 & 44,0 & 18,0 & 4,2 & 2,7 \\
\hline Japão & 10,0 & 36,0 & 18,0 & 3,8 & 2,5 \\
\hline Rússia & 10,0 & 44,0 & 20,0 & 4,0 & 2,55 \\
\hline Suécia & 10,0 & $44,0(60,0)$ & $18,72(25,25)$ & 4,0 & 2,55 \\
\hline Tailândia & 9,1 & 37,4 & 10,0 & 4,0 & 2,5 \\
\hline Reino Unido & 10,0 & 44,0 & 18,75 & 4,0 & 2,55 \\
\hline EUA & 9,1 & $36,3(59,45)$ & $19,80(35,20)$ & 4,1 & 2,6 \\
\hline
\end{tabular}

( ) os valores entre parênteses são permitidos mediante emissão de $\mathrm{AET}^{3}$

Um dos sinais desta evolução é a crescente demanda por Autorização Especial de Trânsito registrada pelo $\mathrm{DNIT}^{4}$, como mostra a Figura 2, uma vez que é possível alterar dimensões e características mecânicas dos veículos mantendo-os certificados para o tráfego.

\footnotetext{
${ }^{3}$ AET - Autorização Especial de Trânsito

${ }^{4}$ DNIT - Departamento Nacional de Infra-Estrutura em Transportes, antigo DNER - Departamento Nacional de Estradas de Rodagem
} 


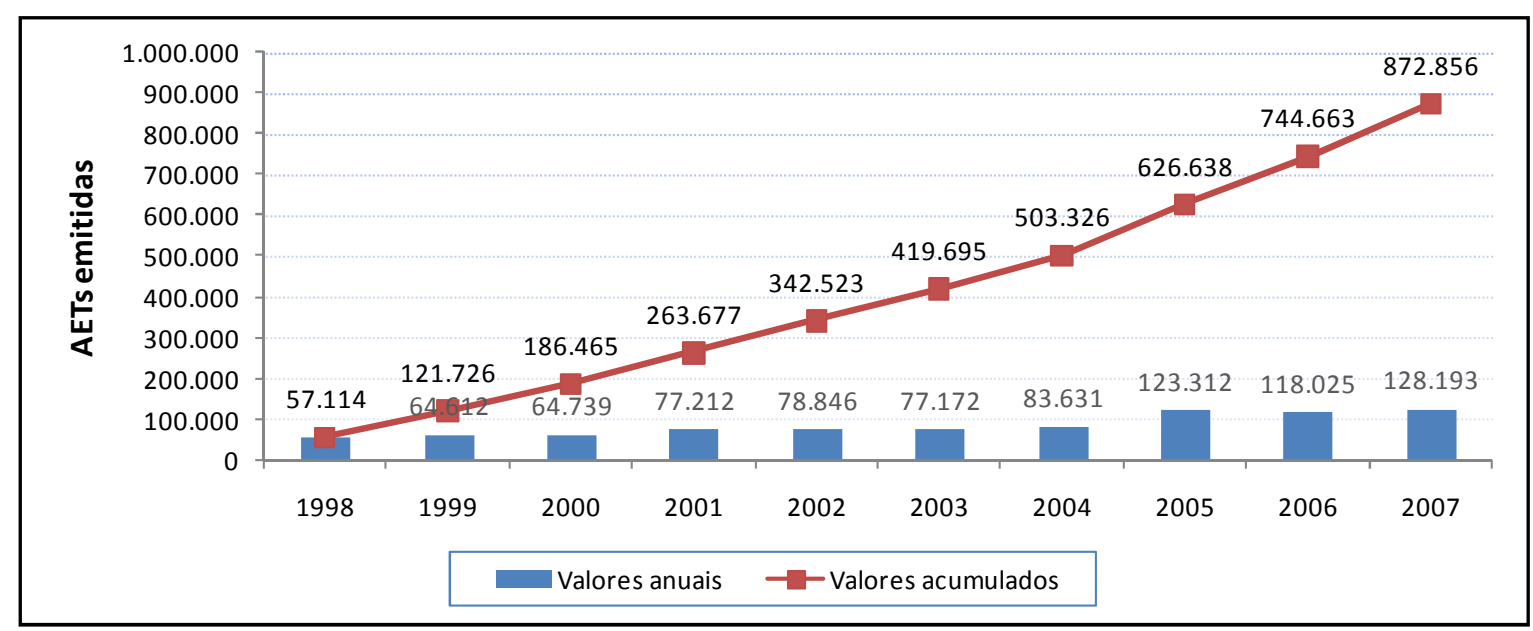

Figura 2: Quantidade de AETs expedidas - SIAET (DNIT, 2007).

As resoluções 210, 211 e 256 do CONTRAN $^{5}$ (BRASIL, 2006a, 2006b e 2007) liberaram o tráfego de CVCs com até sete eixos, sem necessidade de AET. A homologação de novas tecnologias rodoviárias afeta o tráfego nas rodovias e carece de estudos que permitam prever o comportamento destes veículos, além de indicar intervenções necessárias no sistema viário, visando garantir a segurança aos demais usuários do sistema de transporte rodoviário.

Com a finalidade de prever o comportamento de caminhões e CVCs, pesquisadores têm desenvolvido diversos modelos matemáticos. Algers et al. (1997) identificaram 58 modelos de micro-simulação.

No cenário apresentado, fica clara a necessidade de estudar modelos dessa natureza e desenvolver ferramentas eficazes e eficientes para avaliar o comportamento de caminhões e CVCs novos ou que já estão em operação, estando estes ou não com suas características originais de fábrica, para que apenas veículos com condições de tráfego compatíveis com a infra-estrutura sejam certificados, ou ainda, que sejam identificadas as mudanças necessárias no sistema viário para nortear ações preventivas e permitir que veículos considerados críticos possam trafegar sem comprometer a segurança e fluidez do tráfego.

\footnotetext{
${ }^{5}$ CONTRAN - Conselho Nacional de Trânsito
} 


\subsection{Objetivo}

Analisar de forma expedita a compatibilidade de tráfego de caminhões e CVCs com trechos de rodovias através de um método baseado em modelos matemáticos já desenvolvidos por outros autores. Além da agilidade das análises, o método aqui desenvolvido possui vantagens como baixo custo das análises, por dispensar ensaios de campo, e alcance a diferentes usuários do sistema rodoviário de transportes (pesquisadores, órgãos governamentais, e operadores de transporte).

Como objetivo secundário, este trabalho complementa a pesquisa de Pereira Neto (2007), questionando a eficácia dos manuais de projeto de rodovias por difundirem métodos que não consideram a evolução dos veículos, seja quanto às dimensões ou ao desempenho veicular. Como exemplos de manuais de projeto de rodovias que não consideram a variabilidade de desempenho de veículos pesados, temos: DNER (1999), TAC (1999), AUSTROADS (2002), AASHTO (2004). 


\subsection{Estrutura do trabalho}

Com o uso extensivo dos computadores diversos modelos matemáticos para determinar o desempenho de veículos foram desenvolvidos. É possível classificar estes modelos segundo áreas de aplicação, como mostra a Figura 3.

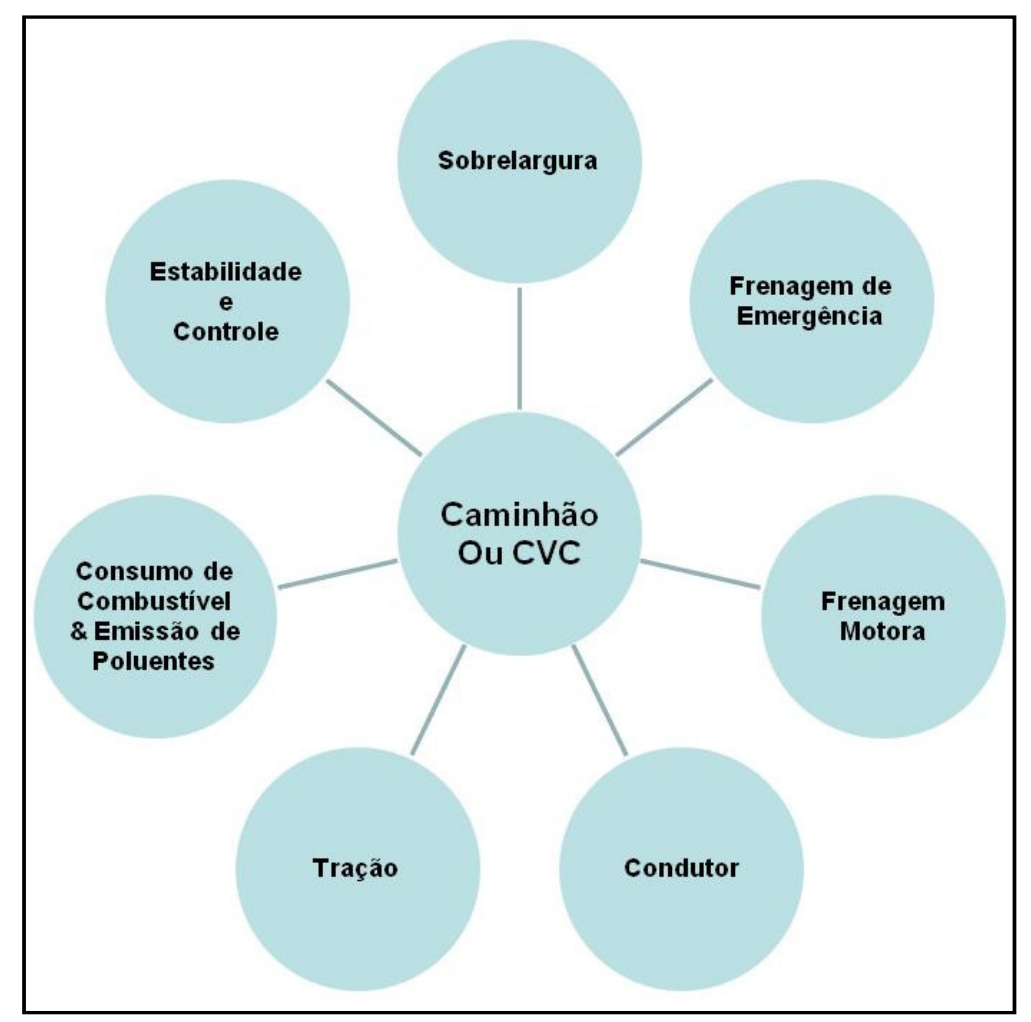

Figura 3: Áreas de aplicação dos modelos de desempenho veicular.

O Capítulo 2 apresenta uma revisão da bibliografia sobre os modelos de micro-simulação segundo as áreas de aplicação apresentadas na Figura 3, bem como uma discussão sobre a aplicabilidade dos modelos em estudos de compatibilidade de tráfego.

O Capítulo 3 propõe um simulador de tráfego para estudar o comportamento de veículos de carga. O simulador é baseado nos modelos estudados no Capítulo 2, e sua acurácia é verificada pela comparação com dados de campo e curvas propostas por manuais de projeto de rodovias. 
O Capítulo 4 apresenta exemplos de análise de compatibilidade de tráfego utilizando o simulador proposto no Capítulo 3.

O Capítulo 5 contém as conclusões alcançadas neste trabalho e sugestões para futuras investigações sobre o tema.

O Capítulo 6 apresenta as referências bibliográficas citadas neste texto.

Nos Anexos A, B e C o leitor encontra respectivamente: a lista completa de variáveis utilizadas pelo simulador, os algoritmos implementados, e o manual do usuário para configurar cenários de simulação.

No Anexo D são apresentados os resultados das simulações realizadas no Capítulo 3, para verificação de consistência do simulador.

O Apêndice I apresenta tabelas encontradas na literatura que auxiliam na escolha e determinação de parâmetros necessários aos modelos apresentados. 


\section{REVISÃO BIBLIOGRÁFICA}

Este capítulo apresenta uma revisão sobre os modelos matemáticos de microsimulação desenvolvidos e validados por outros pesquisadores. $O$ estudo dos modelos foi realizado de acordo com cada área de aplicação apresentada na Figura 3 da página 7 :

\subsection{Tração}

2.2 Frenagem motora

2.3 Frenagem de emergência

2.4 Sobrelargura

2.5 Estabilidade e controle

2.6 Comportamento do condutor

2.7 Consumo de combustível e emissão de poluentes.

Após a análise dos modelos em cada área de aplicação, é realizada uma discussão sobre as limitações e aplicabilidade desses em análises de compatibilidade de tráfego. Também são discutidas as regulamentações pertinentes a cada área. 


\subsection{Tração}

Os modelos de tração são a base para os trabalhos com micro-simulação de veículos, pois é através deles que a potência desenvolvida pelo motor relacionase matematicamente com as resistências ao movimento para determinar o perfil de velocidades desenvolvidas ao longo de um trecho de rodovia, bem como as acelerações e o tempo total de percurso. Os modelos de tração podem ser classificados em: empíricos, analíticos, ou de micro-simulação.

Modelos empíricos são aqueles obtidos pela observação e coleta de dados de perfis de velocidade de veículos em rodovias, o que pode ser feito equipando um veículo com aparelhos que registrem sua velocidade ao longo do tempo ou acoplando um aparelho GPS de navegação, que fornece exatidão suficiente para esse fim. Após a coleta dos dados, equações para representar o fenômeno são propostas, e através de estudos de regressão numérica os dados coletados são utilizados para calibrar os coeficientes dessas equações.

Modelos analíticos baseiam-se na mecânica de locomoção de veículos, e podem ser representados por um conjunto de forças atuando em um veículo em movimento. Através dos modelos analíticos é possível criar curvas de desempenho para operações em condições pré-definidas.

Modelos de micro-simulação podem ser entendidos como uma aplicação dos modelos analíticos, cujos resultados são válidos durante um intervalo incremental de tempo e servem como parâmetros de entrada de um processo iterativo.

O Highway Capacity Manual - HCM, referência em estudos de cálculo de equivalente veicular para projeto de rodovias, utiliza curvas de aceleração e desaceleração baseadas em modelos analíticos, como as exibidas na Figura 4. 


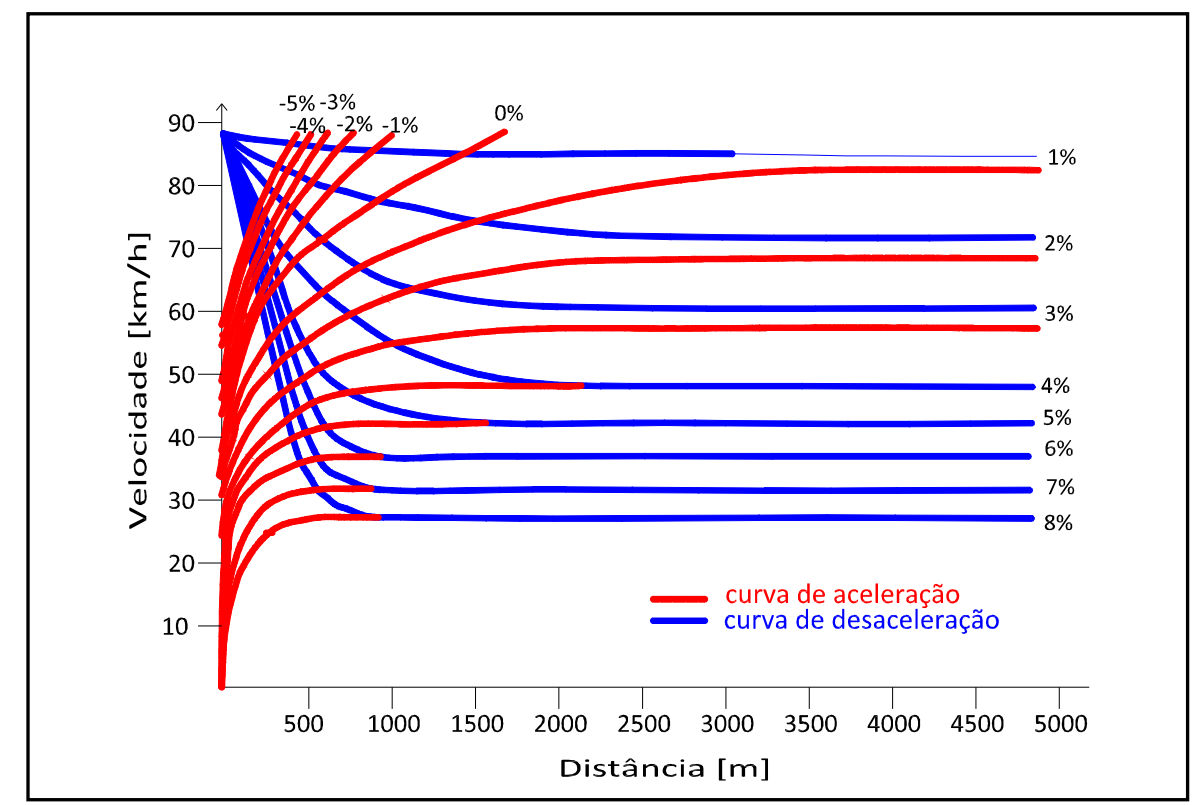

Figura 4: Curvas de desempenho para veículos com 200 lb/hp, aproximadamente 11cv/t (HCM 1997, apud Lucic, 2001).

A utilização de curvas relacionando velocidade e distância percorrida é fundamental para determinar comprimento de rampas de aceleração e desaceleração, além de auxiliar na definição da posição de início e comprimento de faixas de ultrapassagem em aclives, necessitando para isso conhecer a velocidade inicial do veículo no trecho.

Pesquisadores do Departamento de Transportes da EESC/USP (Demarchi \& Setti, 1998; Demarchi, 2000) desenvolveram um modelo analítico simplificado, baseado na mecânica de locomoção de veículos, cujo princípio é a aplicação da segunda Lei de Newton, como ilustra a Figura 5. 


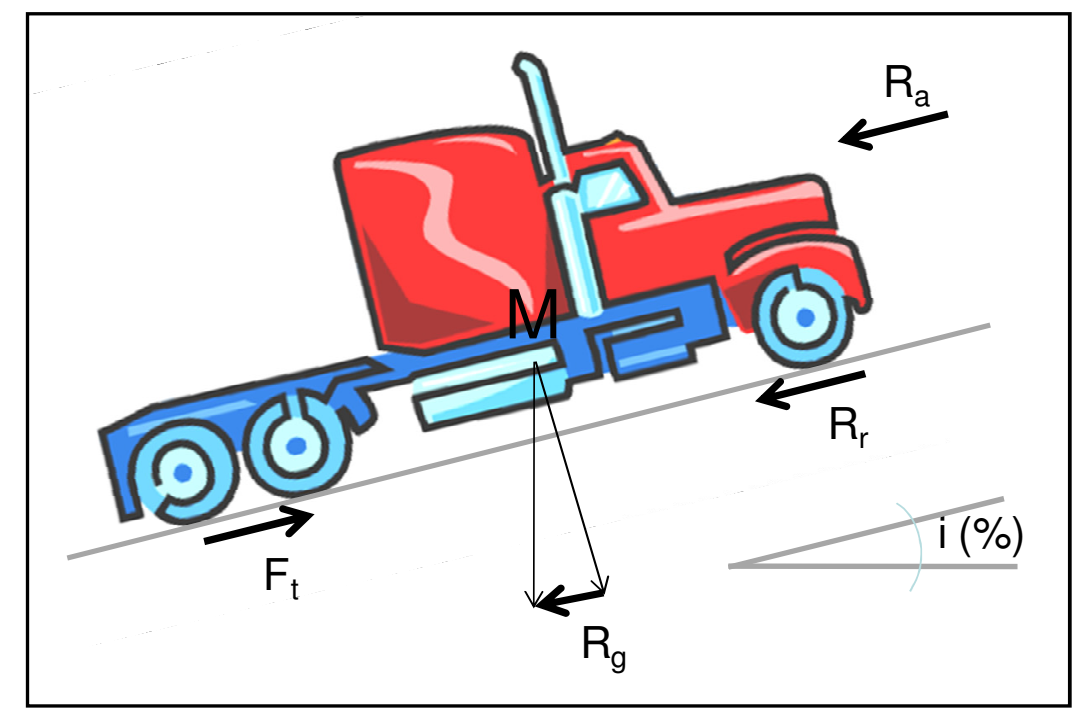

Figura 5: Esquema de forças agindo sobre um veículo em movimento.

Admitindo o veículo como um corpo rígido, temos a equação de equilíbrio de forças que agem sobre o veículo em movimento, dada pela Equação 1.

$a=\frac{F_{t}-\sum R}{M}$

(Equação 1)

em que:

$a=$ aceleração $\left(\mathrm{m} / \mathrm{s}^{2}\right)$

$F_{t}=$ força de tração nos pneumáticos $(\mathrm{N})$

$R=$ soma das forças de resistência ao movimento, $R_{a}, R_{r}, R_{g}(N)$

$\mathrm{M}=$ massa do veículo $(\mathrm{kg})$

A força de tração nos pneumáticos pode ser obtida da relação entre potência, força e velocidade, dada pela Equação 2.

$F_{\text {tração, }, \text { motor }}=3600 * \eta * \frac{P}{V}$

(Equação 2)

em que:

$F_{\text {tração,motor }}=$ força máxima de tração devida ao motor $(\mathrm{N})$

$\mathrm{P}=$ potência fornecida pelo motor $(\mathrm{kW})$

$\eta$ = eficiência da transmissão da força gerada no motor aos eixos tratores

$\mathrm{V}=$ velocidade do veículo $(\mathrm{km} / \mathrm{h})$

O parâmetro 3600 refere-se à conversão de unidades 
No entanto, a força de tração é limitada pelo atrito máximo existente entre os pneumáticos e a superfície da rodovia, como mostra a Equação 3.

$F_{\text {tração,atrito }} \leq W_{t a} * \mu$

em que:

$\mathrm{F}_{\text {tração,atrito }}=$ força máxima de tração devida ao atrito $(\mathrm{N})$

$\mathrm{W}_{\mathrm{ta}}=$ força peso aplicada sobre os eixos tratores $(\mathrm{N})^{6}$

$\mu$ ou $\mathrm{u}=$ coeficiente de atrito longitudinal

Assim, a força de tração nos pneumáticos da Equação 1 será a menor entre a força gerada no motor e transmitida aos eixos tratores e a força de atrito máxima permitida.

$F_{t}=\min \left(F_{\text {trasăoo,motor }}, F_{\text {traşăo,atrito }}\right)$

A energia liberada na queima do combustível no motor é convertida em um movimento de rotação no vira-brequim ${ }^{7}$. Os motores são caracterizados por seus fabricantes por curvas que relacionam a potência fornecida com a queima do combustível com a rotação motora, como exemplifica a Figura 6 . As curvas apresentadas nesta figura são importantes, pois a partir delas é possível determinar a força de tração nos eixos motrizes. Analogamente é possível relacionar o consumo específico de combustível e o torque do motor com a rotação do mesmo.

A potência utilizada para o cálculo da Equação 2 é fornecida pelos fabricantes de motores. Comumente estes divulgam em seus catálogos a curva de potência máxima fornecida em função da rotação do motor. Contudo, para uma mesma rotação é possível obter potências inferiores à potência máxima, sendo que o conjunto dos pontos formados pelas potências máximas e intermediárias compõe o mapa de desempenho do motor, que atualmente não é disponibilizada

\footnotetext{
${ }^{6}$ No caso de veículos com dois ou mais eixos tratores, deve ser considerada a soma dos pesos em todos os eixos que tracionam o veículo. Exemplo: Unidades Tratoras 6x4.

${ }^{7}$ Vira-brequim: eixo conectado aos pistões do motor que transforma o movimento oscilatório dos pistões em movimento rotacional.
} 
pelos fabricantes. Para modelos mais elaborados de tração recomenda-se a utilização do mapa de desempenho.

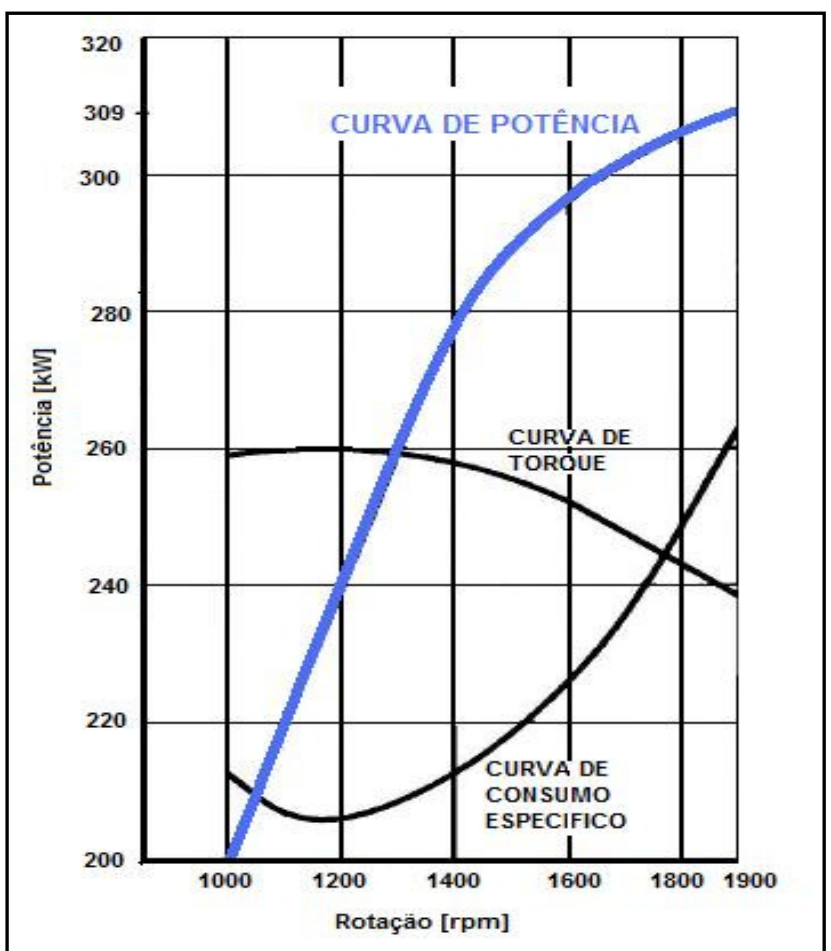

Figura 6: Curvas de potência máxima, torque e consumo específico contra rotação do motor.

O movimento de rotação no vira-brequim do motor, em veículos pesados e extra-pesados, varia tipicamente de 1000 a 3000 rotações por minuto (rpm). Para compatibilizar o movimento de rotação desse com a rotação dos pneumáticos existem a caixa de mudanças e o diferencial, que através de engrenagens mecânicas tornam isto possível, de tal forma que o número de rotações no vira-brequim tenha uma equivalência com o número de rotações do pneumático, o que pode ser expresso pela Equação 5.

$$
V=3,6 \cdot 0,06 \cdot \pi \cdot \phi_{d} \cdot \frac{N}{g_{t} \cdot g_{d}}
$$

em que:

$$
\begin{aligned}
& V=\text { velocidade do veículo }(\mathrm{km} / \mathrm{h}) \\
& \phi_{d}=\text { diâmetro dinâmico do pneumático }(\mathrm{m}) \\
& \mathrm{N}=\text { número de rotações por minuto no vira-brequim (rpm) }
\end{aligned}
$$


$g_{d}=$ relação de redução no diferencial

$\mathrm{g}_{\mathrm{t}}=$ relação de redução na caixa de mudanças

Os parâmetros 3,6 e 0,06 referem-se à conversão de unidades.

As forças de resistência ao movimento da Equação 1 podem ser divididas em três tipos: rolamento, aerodinâmica e rampa (Mannering \& Kilareski, 1990; Fitch, 1994; Archilla \& De Cieza, 1996) ${ }^{8}$.

$R=R_{r}+R_{a}+R_{g}$ (Equação 6)

em que:

$\mathrm{R}$ = soma das forças de resistência ao movimento $(\mathrm{N})$

$\mathrm{R}_{\mathrm{r}}=$ resistência ao rolamento $(\mathrm{N})$

$\mathrm{R}_{\mathrm{a}}=$ resistência aerodinâmica $(\mathrm{N})$

$\mathrm{R}_{\mathrm{g}}=$ resistência de rampa $(\mathrm{N})$

A resistência de rolamento leva em conta a energia necessária para vencer o atrito existente entre as partes mecânicas do motor, caixa de mudanças, eixo cardan, diferencial, semi-eixo trator, rodas, pneumático e pavimento, e pode ser calculada pela Equação 7 .

$R_{r}=C_{r} .\left(C_{2}+V \cdot C_{3}\right) * W$

(Equação 7)

em que:

$\mathrm{R}_{\mathrm{r}}=$ resistência ao rolamento $(\mathrm{N})$

$\mathrm{C}_{\mathrm{r}}=$ coeficiente para condições da superfície de rolamento

$\mathrm{C}_{2}=$ coeficiente para o tipo de pneumático

$\mathrm{C}_{3}=$ coeficiente para o tipo de pneumático e outros fatores

$\mathrm{V}=$ velocidade do veículo $(\mathrm{km} / \mathrm{h})$

$\mathrm{W}=$ peso do veículo $(\mathrm{kN})$

${ }^{8}$ A Resistência de Curva é desprezada, por admitir o tráfego dos veículos em velocidades baixas. 
A resistência aerodinâmica é a força de arraste a que todo objeto que se movimenta em um fluído está submetido; é função da área frontal do veículo, da altitude, do coeficiente de arrasto do veículo, e da velocidade de operação.

Em elevadas altitudes o ar se torna mais rarefeito, o que diminui sua viscosidade e, portanto, a resistência aerodinâmica. A Equação 8 representa o fenômeno.

$R_{a}=C_{1} \cdot C_{d} \cdot C_{h} \cdot A_{f} \cdot V^{2}$ (Equação 8)

em que:

$\mathrm{R}_{\mathrm{a}}=$ resistência aerodinâmica $(\mathrm{N})$

$A_{f}=$ área frontal do veículo $\left(\mathrm{m}^{2}\right)$

$\mathrm{C}_{1}=$ densidade do ar ao nível do mar e temperatura de $15^{\circ} \mathrm{C}$

$\mathrm{C}_{\mathrm{d}}=$ coeficiente de arrasto

$C_{h}=1-8,5 \times 10^{-5} \times H$, para $\mathrm{H}$ a altitude em metros (Watanatada et al, 1987)

$\mathrm{V}=$ velocidade do veículo $(\mathrm{km} / \mathrm{h})$

A resistência de rampa é a força necessária para o veículo vencer determinado aclive, ou a força adicional que acelera o veículo em declives. É obtida diretamente pela componente vetorial da força peso na direção do movimento, sendo que para baixas declividades como usualmente ocorre em rodovias (inferiores a $12 \%$ ), permite a simplificação $\operatorname{sen}(\Phi)=\operatorname{tg}(\Phi)=\mathrm{i}$, como ilustra a Figura 5. A Equação 9 permite quantificar o valor destas forças.

$R_{g}=1000 \cdot W \cdot i$ (Equação 9)

em que:

$\mathrm{R}_{\mathrm{g}}=$ resistência de rampa $(\mathrm{N})$

$\mathrm{W}=$ peso do veículo $(\mathrm{kN})$

$\mathrm{i}$ = inclinação da pista, positiva no sentido ascentende e negativa no sentido descendente $(\mathrm{m} / \mathrm{m}$ ou \%)

Estabelecidos os conceitos de força de tração e resistência ao movimento para veículos rodoviários de carga, é possível traçar um gráfico de velocidade 
contra força que resume as situações possíveis de operação de um veículo cujas características mecânicas foram previamente definidas, mediante a aplicação das equações apresentadas, como mostra a Figura 7.

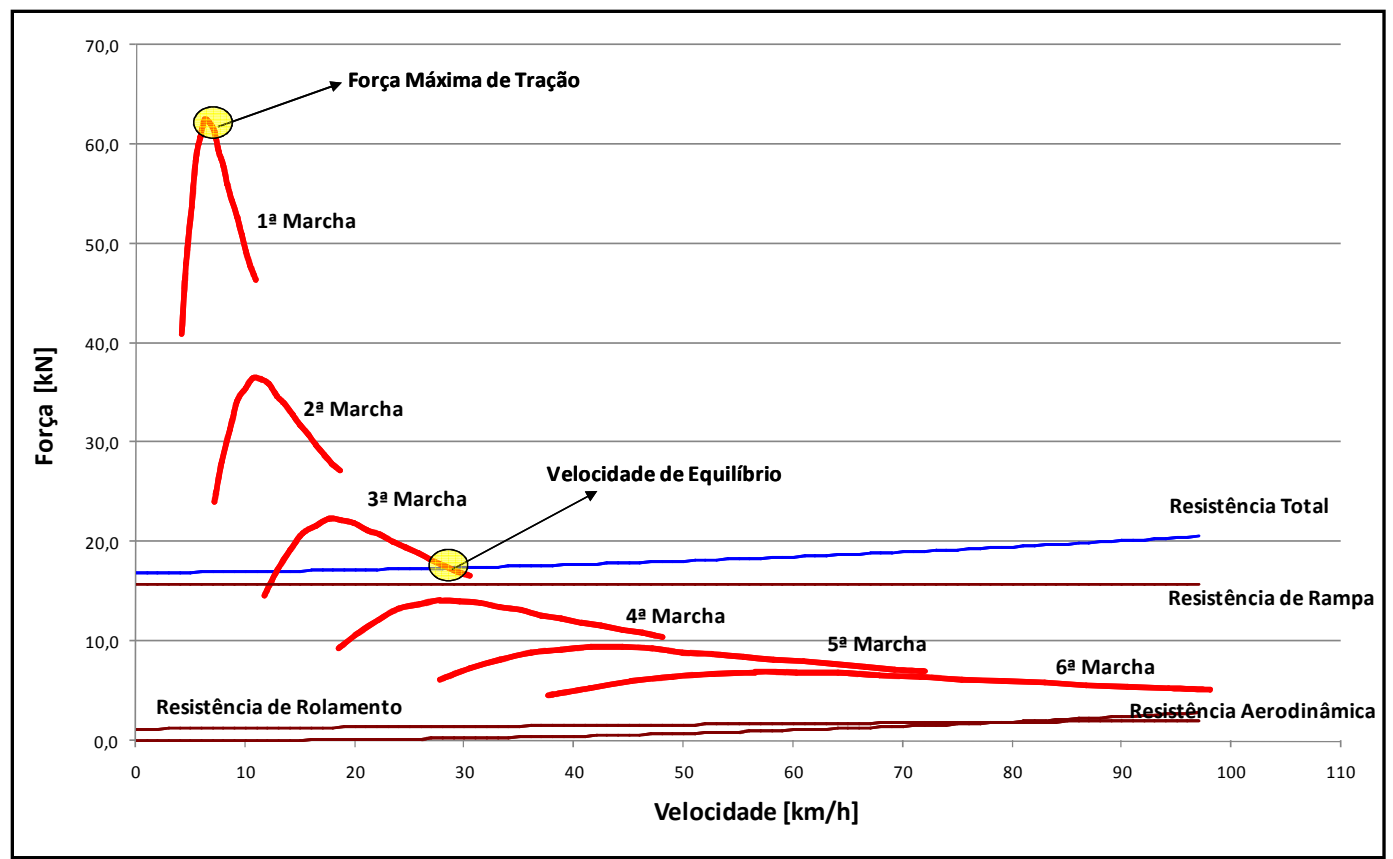

Figura 7: Curvas de tração e resistência ao movimento.

Algumas conclusões podem ser tiradas da análise do gráfico da Figura 7, como:

1) Velocidade máxima operacional: é o valor da extrema direita da curva de tração da última marcha (menor valor de $g_{t}$ ), que representa o ponto de maior rotação do motor e a marcha de menor valor de redução

2) Velocidade de equilíbrio: é a velocidade em que as forças de tração e resistência ao movimento assumem o mesmo valor, de modo que a velocidade não pode aumentar pois não há potência motora suficiente para vencer a resistência ao movimento.

3) Aceleração máxima: é a maior distância, no eixo das ordenadas, entre uma curva de tração e a curva de resistência ao movimento, dividida pela massa do veículo. 
Os conceitos discutidos até agora estão associados aos modelos analíticos até então desenvolvidos. O modelo de simulação utiliza esses conceitos da seguinte forma: após o incremento de tempo de 0,01 segundo (tempo suficiente para um veículo a $100 \mathrm{~km} / \mathrm{h}(27,7 \mathrm{~m} / \mathrm{s})$ percorrer $0,27 \mathrm{~m}$, distância adotada pelo autor como suficiente para a precisão dos resultados desejados ${ }^{9}$ ) o veículo desloca-se e altera sua posição no espaço e no tempo, permitindo assim que outros parâmetros sejam atualizados, como inclinação da pista, velocidade, rotação, potência do motor, etc. Então uma nova iteração é iniciada e o processo repetese até que o veículo percorra todo o trecho. A estrutura do algoritmo de simulação pode ser representada pela Figura 8.

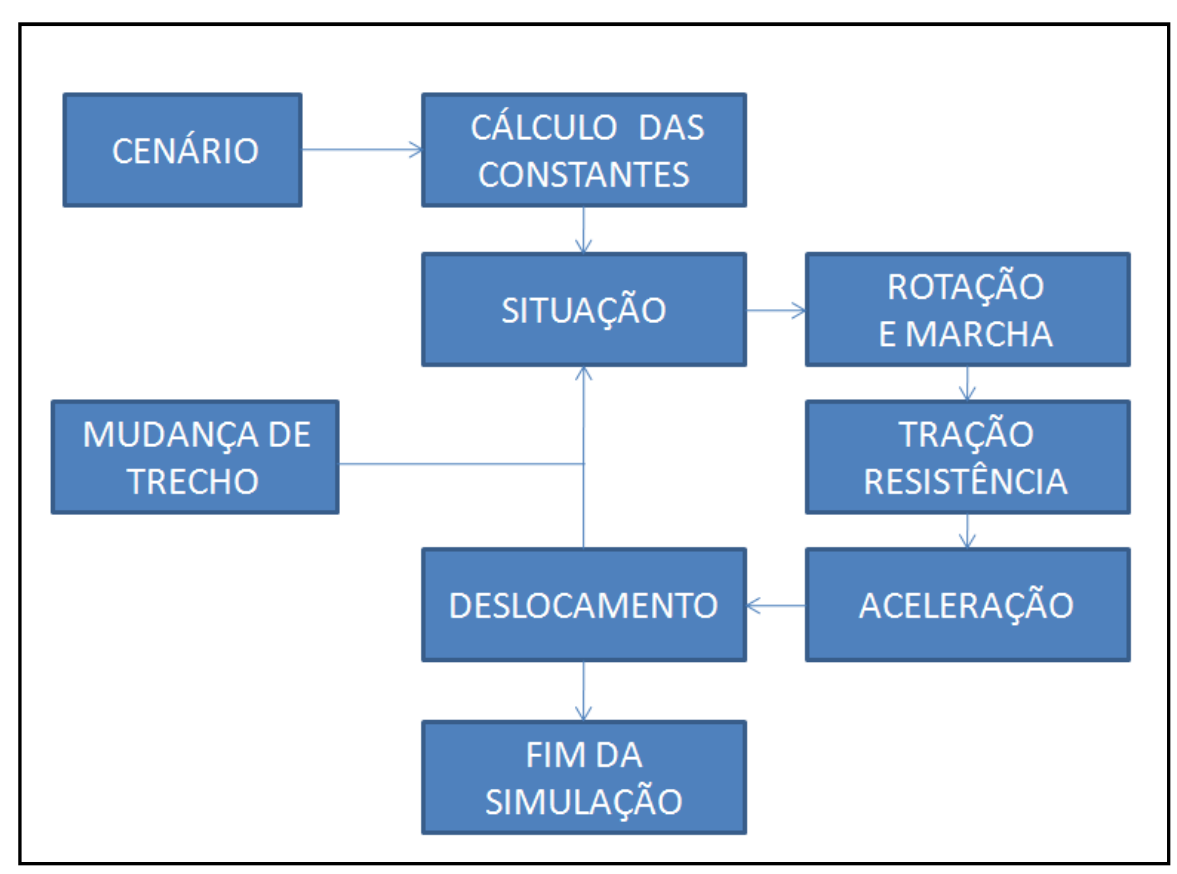

Figura 8: Estrutura do simulador de tração.

O modelo analítico apresentado foi validado por Melo (2002), e é adotado também pela Society of Automotive Engineering - SAE em seu procedimento J2188 (SAE, 1996) para cálculo de curvas de aceleração e desaceleração.

\footnotetext{
${ }^{9} \mathrm{O}$ incremento de tempo utilizado para o cálculo iterativo não é necessariamente o incremento de tempo entre os resultados apresentados, uma vez que para estes é possível exibi-los por incrementos de tempo, espaço, velocidade, aceleração ou outra variável desejada (ver Anexo C - Manual do Usuário)
} 
As regulamentações brasileiras explicitadas a seguir tratam da capacidade que uma unidade tratora deve ter para tracionar uma ou mais unidades, estando diretamente relacionadas aos conceitos envolvidos nos modelos de tração.

\section{Portaria no 1 do INMETRO de 10/04/89 (INMETRO, 1989)}

"Art.1ํ - Estabelecer os valores limites de Peso Bruto Total (PBT) e a Capacidade Máxima de Tração $\left(\mathrm{CMT}^{10}\right)$ dos veículos de transporte de carga e de transportes coletivos de pessoas.

I - "Os veículos de transporte de carga, deverão observar provisoriamente o limite mínimo fixado para relação potência/peso de $4,2 \mathrm{~kW} / \mathrm{t}(\sim 5,71 \mathrm{cv} / \mathrm{t})$, considerando a potência máxima efetiva líquida apurada no ensaio do motor utilizado, ensaio esse realizado conforme as NBR no 5 5477/82 e 5484/85"."

\section{Resolução № 210 DE 13/11/2006 (BRASIL, 2006a)}

"Estabelece os limites de peso e dimensões para veículos que transitem por vias terrestres e dá outras providências."

Determina as dimensões e peso máximos para veículos com PBTC até 57t e comprimento máximo de 19,80m circularem. Faz referência a norma NBR NM ISO 1726 que trata do balanço dianteiro de semi-reboques, e NBR NM ISO337, sobre acoplamento de unidades. Estabelece que deve haver compatibilidade entre CMT da unidade tratora e PBTC do veículo.

\section{Resolução № 211 DE 13/11/2006 (BRASIL, 2006b)}

"Requisitos necessários à circulação de Combinações de Veículos de Carga - CVC, a que se referem os arts. 97, 99 e 314 do Código de Trânsito Brasileiro-CTB."

\footnotetext{
${ }^{10}$ CMT - Capacidade Máxima de Tração: valor em toneladas atribuído à unidade tratora como o valor máximo de Peso Bruto Total Combinado - PBTC que esta é capaz de tracionar. A eficácia deste parâmetro como medida de desempenho é questionada em SOUZA (2007).
} 
Determina que veículos com PBTC superior a $57 \mathrm{t}$ e inferior a $74 \mathrm{t}$, comprimento superior a 19,80m e inferior a 30,00m, necessitam de AET para circular, documento emitido por órgãos executivos rodoviários. Devem cumprir a Resolução n․ 777/93 do Contran, sobre sistemas de freios; e as NBR 11410/11411 e NBR NM/ISO 337, sobre acoplamento de unidades.

Estabelece requisitos técnicos mínimos para o tráfego de veículos com AET, assim como medidas complementares, horários de circulação, velocidade máxima, projeto do veículo e laudo técnico da capacidade de desempenho do veículo. Apresenta a Equação 10 para cálculo da capacidade de rampa.

$$
i_{\max }=\frac{F_{t}}{10 \cdot G}-\frac{R_{r}}{10}
$$

em que:

$$
\begin{aligned}
& \mathrm{I}_{\max }=\text { inclinação máxima de pista }(\mathrm{m} / \mathrm{m} \text { ou \%) } \\
& \mathrm{F}_{\mathrm{t}}=\min \left(\mathrm{F}_{\mathrm{r}}, \mathrm{F}_{\text {tração,atrito }}\right) \\
& \mathrm{G}=\text { peso bruto total combinado }(\mathrm{t}) \\
& \mathrm{R}_{\mathrm{r}}=\text { resistência ao rolamento }
\end{aligned}
$$

Apresenta ainda a Equação 11 para cálculo da força de tração motora máxima possível, limitada pela força máxima de aderência (Equação 3).

$$
F_{r}=\frac{T m \cdot i c \cdot i d \cdot 0,9}{\phi_{d} / 2}
$$

em que:

$$
\begin{aligned}
& F_{r}=\text { força na roda }(\mathrm{kgf}) \\
& T m=\text { torque máximo do motor }(\mathrm{kgf} . \mathrm{m}) \\
& \text { ic = maior relação de redução da caixa de câmbio (1a marcha) } \\
& \text { id = relação de redução no eixo traseiro (diferencial) } \\
& \Phi_{\mathrm{d}}=\text { diâmetro dinâmico do pneumático }(\mathrm{m})
\end{aligned}
$$


Resolução № 256 DE 30/11/2007 (BRASIL, 2007)

"Altera o $\S 2^{\circ}$, do art. $2^{\circ}$ da Resolução ํㅜ 211, de 13 de novembro de 2006,

do CONTRAN". Permite que unidades tratoras 4x2 tracionem CVCs com até 57 toneladas. 


\subsection{Frenagem motora}

Os motores de unidades tratoras podem ser utilizados não só como fonte de energia para tração mas também para reduzir a velocidade dos veículos em declives, em situações cuja magnitude da força de resistência de rampa seja superior a soma das resistências de rolamento $\left(R_{g}\right)$ e aerodinâmica $\left(R_{a}\right)$.

Quando isto acontece e o veículo não é acelerado pelo condutor, ocorre uma inversão no funcionamento do motor, que ao invés de gerar energia para movimentar o veículo passa a atuar como um compressor de ar, que absorve a energia cinética que o veículo tenta adquirir ao percorrer o declive (Fernandes, 1994)

Ao trafegar por uma rodovia o condutor deve controlar a velocidade do veículo em trechos com inclinações positivas ou negativas, e ainda ser capaz de realizar uma frenagem de emergência para desviar de um obstáculo ou evitar um acidente. Executar frenagens de emergência só é possível caso o sistema de freios auxiliares do veículo assim permita, o que não ocorre quando os freios auxiliares são utilizados constantemente e superaquecem, ocorrendo o fenômeno conhecido por "fading".

O fenômeno "fading" pode ser entendido como uma diminuição acentuada do desempenho do sistema de freios de serviço pelo aumento excessivo da temperatura de seus componentes (Canale et al, 2005).

Conseqüentemente, quando o condutor opta por não utilizar o freio motor e manter velocidade constante em longos declives utilizando para isso os freios de serviço, compromete sua segurança e dos demais usuários da rodovia, uma vez que a dissipação de energia nos freios auxiliares ocorre pela conversão da energia cinética em calor e ruído (condução, convecção e radiação), por atrito entre os componentes desse sistema, cuja capacidade de dissipação de energia é limitada pela capacidade térmica dos conjuntos de freio (tambor e lona). A seção 2.3 apresenta uma discussão aprofundada sobre o sistema de freios de serviço de veículos de carga. 
Em suma, ao utilizar constantemente os freios de serviço, o condutor promove o aquecimento desse sistema, que perde sua eficiência, fenômeno conhecido como Fading, que inevitavelmente ocorre em longos percursos de descida.

Para trafegar com segurança em longos declives é desejável que o condutor mantenha a velocidade utilizando o freio motor. No entanto, muitas vezes a energia cinética que um caminhão ou CVC adquire ao percorrer um declive pode estar acima da capacidade de dissipação do freio motor, para isto foram criados mecanismos que geram uma potência adicional de frenagem motora, conhecidos como retardadores de velocidade ou retarders.

Para evitar a perda de dirigibilidade e controle do veículo os próprios motoristas baseados na experiência acumulada ao longo dos anos se impõem critérios - na maioria das vezes subjetivos - para percorrer longos trechos com segurança. Via de regra esses critérios resumem-se a reduzir a velocidade de deslocamento do veículo, às vezes a valores muito inferiores ao que poderia ser praticado. É possível determinar para cada declividade e comprimento de rampa conhecidos, a maior velocidade teórica que um veículo pode utilizar para vencer um declive utilizando apenas o freio motor e mantendo os freios auxiliares em temperatura aceitável para realizar com segurança, após a descida, uma frenagem de emergência (Lucas, 2004).

Considerando que deva haver equilíbrio entre a energia adquirida ao percorrer um declive e a energia dissipada pelos sistemas de freio motor e freio auxiliar, Lucas (2004) modelou o fenômeno possibilitando assim calcular a temperatura do sistema de freios e a máxima velocidade de segurança com que um veículo pode percorrer um trecho com inclinação definida. O modelo desenvolvido parte da condição de equilíbrio semelhante a do modelo de tração, porém aplicando o conceito de equilíbrio de potência, produto da força pela velocidade. 
$P_{B}+P_{B M}=V *\left(R_{G}-R_{R}-R_{A}\right)$ (Equação 12)

em que:

$P_{B}=$ potência dissipada pelo sistema de freios (watts)

$\mathrm{P}_{\mathrm{BM}}=$ potência dissipada pelo freio motor (watts)

$\mathrm{V}=$ velocidade do veículo $(\mathrm{m} / \mathrm{s})$

Integrando a Potência em relação ao tempo (t) de utilização do sistema de freios, em segundos, temos:

$P_{B}+P_{B M} * t=V * t *\left(R_{G}-R_{R}-R_{A}\right)$

Sabendo que o produto da potência pelo tempo é a energia, e que o deslocamento ou espaço percorrido pelo veículo (L) é o produto da velocidade (V) pelo tempo (t) temos:

$Q_{B}+Q_{B M} * \frac{L}{V}=L *\left(R_{G}-R_{R}-R_{A}\right)$ (Equação 14)

em que:

$\mathrm{Q}_{\mathrm{B}}=$ quantidade de calor armazenada nos tambores de freios $(\mathrm{J})$

$\mathrm{Q}_{\mathrm{MB}}=$ quantidade de calor armazenada no freio motor $(\mathrm{J})$

$\mathrm{L}=$ deslocamento ou espaço percorrido pelo veículo $(\mathrm{m})$

O calor gerado promove o aquecimento das partes mecânicas do sistema de freios, cuja variação de temperatura é dada pela Equação 15, conhecida por "Equação Fundamental da Calorimetria".

$\Delta T=\frac{Q_{B}}{c * W_{d r}}$ (Equação 15)

em que:

$\Delta \mathbf{T}=$ variação da temperatura no conjunto de freio ( ${ }^{\circ} \mathrm{C}$ ou Kelvin)

$\mathrm{C}=$ calor específico do material das panelas $\left(\mathrm{J} / \mathrm{kg}^{*} \mathrm{Kelvin}\right)^{11}$

$\mathrm{W}_{\mathrm{dr}}=$ Peso do tambor ou disco $(\mathrm{kg})^{12}$

\footnotetext{
${ }^{11}$ Material das panelas de freio: $419 \mathrm{~J} / \mathrm{kg}$.Kelvin

${ }^{12}$ Conjunto de freio: peso varia tipicamente de 40 a $90 \mathrm{~kg}$.
} 
Segundo Lucas (2004) a temperatura normal de operação do sistema de freios de serviço a tambor é da ordem de $50 \stackrel{\circ}{\circ}$, e a temperatura para ocorrência de "fade" é aproximadamente $350^{\circ} \mathrm{C}$, o que resulta em uma capacidade limite de dissipação de energia pelos freios auxiliares de $300^{\circ} \mathrm{C}$ por conjunto de freio.

A modelagem apresentada é válida para o sistema de freios a tambor, pois considera que toda a energia é absorvida pelo sistema. Para o sistema de freios a discos faz-se necessária uma adaptação do modelo para representar a dissipação de calor pela passagem de ar nas laterais do disco de freio, princípio fundamental de funcionamento desta tecnologia e desprezado nos cálculos matemáticos apresentados.

\subsubsection{Normas e regulamentações}

\section{Resolução № 777 DE 17/12/1993 (BRASIL, 1993)}

"Dispõe sobre os procedimentos para avaliação dos sistemas de freios de veículos."

Estabelece normas da ABNT (NB 1253, NB 1254, NB 1255, MB 3160 (atual NBR10967) e MB 3161) como método para ensaio e requisitos mínimos para avaliação do sistema de freios. Estas normas são baseadas nos regulamentos da Comunidade Européia - ECE - R13.

\section{Norma européia ECE-R13}

Em seu ensaio Tipo II, para caminhões pesados (categoria $\mathrm{M}_{3}$ e $\mathrm{N}_{3}$ ), estabelece que para os ensaios de desempenho, o freio motor em descidas de rampas longas, com ou sem auxílio de retardadores de potência ${ }^{13}$, deve ser capaz de absorver energia equivalente a produzida ao percorrer um declive de $6,0 \mathrm{~km}$, com inclinação de $6 \%$, a $30 \mathrm{~km} / \mathrm{h}$, com a marcha apropriada engrenada.

\footnotetext{
${ }^{13}$ Retardadores de Potência ou Retarders: dispositvos acoplados ao veículo que geram potência adicional de frenagem motora.
} 
NBR 10967 (anterior MB-3160) (ABNT, 1999)

Faz referência a norma européia ECE-R13. Canale (2005) apresenta uma descrição mais detalhada sobre estas e outras normas em vigor no Brasil e no mundo, e conclui que as sucessivas emendas e adaptações às normas ECE-R13 e EEC-Directive 71/320 dão como resultado que as diferenças entre elas na atualidade são insignificantes. Em seu trabalho propõe normas específicas para caminhões que pretendem percorrer a rodovia SP 160 (Nova Imigrantes), principal via de acesso de São Paulo à Baixada Santista, e possui grande trecho em declive.

Canale et al (2005) apresentam um exemplo de carta de retardação, que relaciona a potência de retardação necessária para o veículo operar em variadas inclinações de pista e velocidades de operação.

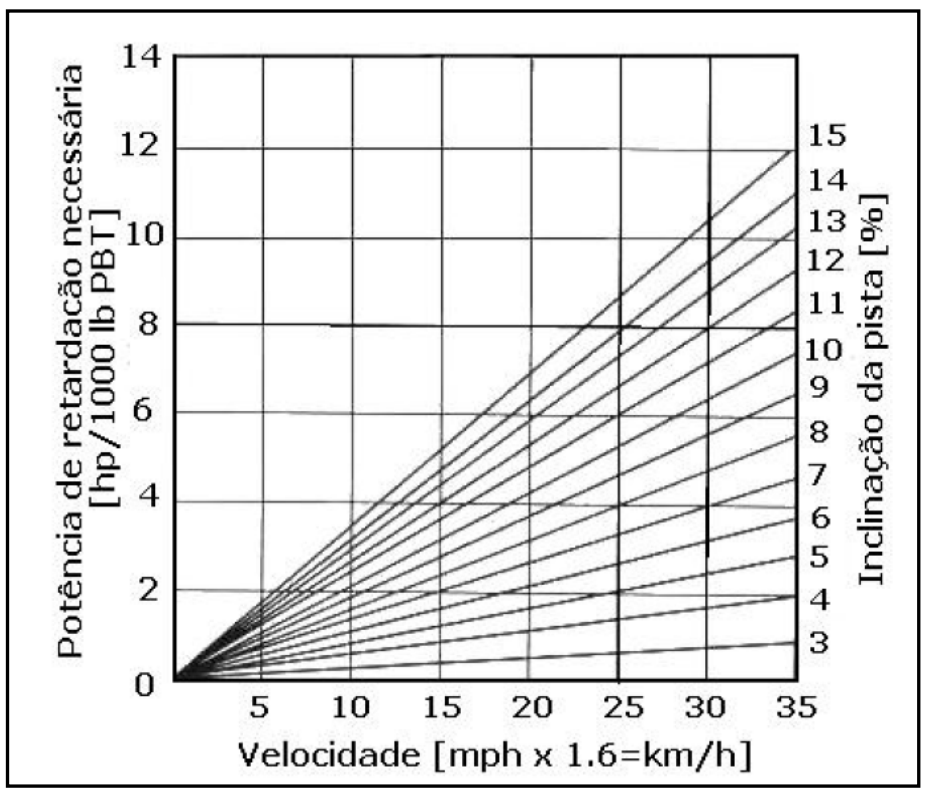

Figura 9: Exemplo de Carta de Retardação (Canale et al, 2005).

A carta de retardação estabelece uma relação direta entre a potência mínima de frenagem motora, com ou sem uso de dispositivos retardadores de potência, que um veículo deve possuir para operar em um trecho de rodovia com geometria conhecida. Observa-se que com o aumento da inclinação da pista (declive) e/ou aumento da velocidade, faz-se necessária uma maior potência disponível para frenagem. 


\subsection{Frenagem de emergência}

O sistema de frenagem é fator relevante no desempenho de veículos rodoviários em relação à segurança nas estradas (VIANA, 2006), uma vez que determina como e com que eficiência o veículo é capaz de reduzir sua velocidade para desviar de um obstáculo, evitar um acidente, ou parar completamente. Para realizar uma frenagem o veículo utiliza seu sistema de freios, que tem por objetivo desacelerar o veículo sem fazer com que esse perca sua estabilidade e dirigibilidade (LIMPERT, 1992). O veículo deve ser capaz de reduzir sua velocidade de forma segura, dentro do menor espaço e tempo possíveis (CANALE, 1991). Em suma, durante a frenagem, o veículo deve:

Conservar a dirigibilidade e estabilidade com qualquer tipo de carregamento permitido pelo seu fabricante;

$\checkmark$ O fenômeno deve ser repetível;

$\checkmark$ Não ter perda significativa de eficiência com temperatura, umidade, água, poeira ou desgaste;

$\checkmark$ Requerer pouca manutenção e ajustes ao longo do tempo;

$\checkmark$ Curto tempo de resposta após o acionamento dos freios;

$\checkmark$ Evitar a ocorrência de fade.

A elevação das relações peso/potência nos veículos de carga em operação no Brasil permite que esses trafeguem pelas rodovias em velocidades superiores às quais as vias foram projetadas, especialmente quanto aos critérios até então adotados para cálculo da distância de frenagem. Uma compensação pode ser feita para veículos que se utilizam do sistema $A B S$ de freios, contudo os manuais de projeto ainda não incorporaram estas considerações. Pereira Neto (2007) faz crítica a adoção em projeto de um valor médio para a relação potência/massa para a frota de veículos, e sugere que condições seguras para frenagem de caminhões e CVCs sejam adotadas em projeto.

Distância de frenagem é definida como sendo a mínima distância que um veículo consegue parar antes de um obstáculo (LUCAS 2004). 
Para o cálculo da distância de frenagem deve ser considerado o tempo de percepção, que é o tempo entre o motorista avistar o obstáculo e o momento em que decide frear.

Para determinar o modo com que veículos rodoviários executam manobras de frenagem, a literatura apresenta os principais fatores que a influenciam:

$\checkmark$ Tipo de sistema de freios

$\checkmark$ Fator de atrito: condições do pavimento e estrutura dos pneumáticos

$\checkmark$ Existência de sistema ABS

$\checkmark$ Condições de carregamento

É possível dividir o sistema de freios em: freio a tambor e freio a disco. $\mathrm{O}$ primeiro consiste de uma campana metálica com uma sapata interna, que quando os freios são acionados expande-se e por atrito (transformação de energia mecânica em calor e ruído) reduz a velocidade do veículo. O segundo sistema, freio a disco, consiste de um disco com duas ou mais sapatas que pressionam o disco quando os freios são solicitados, e também por atrito reduzem a velocidade do veículo.

Toda a força gerada pelo sistema de freio é transmitida ao pavimento pelos pneumáticos, sendo estes também responsáveis pela força máxima que o veículo pode utilizar para reduzir sua velocidade. Os pneumáticos possuem uma estrutura anisotrópica, ou seja, apresentam diferentes comportamentos elásticos nos três planos dimensionais. O projeto do pneumático adequado para cada veículo depende ainda da força normal aplicada e da velocidade que o veículo atuará. Assim sendo, conhecer o comportamento dos pneumáticos em manobras de frenagem é fundamental para determinar a capacidade do veículo de reduzir sua velocidade.

Durante a frenagem o fator de atrito varia de acordo com a porcentagem de escorregamento do pneumático em relação ao pavimento. Segundo Miliken (1995), em um trecho retilíneo (ângulo de deriva do veículo igual a zero) o apro- 
veitamento do atrito é máximo quando o escorregamento relativo situa-se entre 15 e 25\%, como mostra a Figura 10.

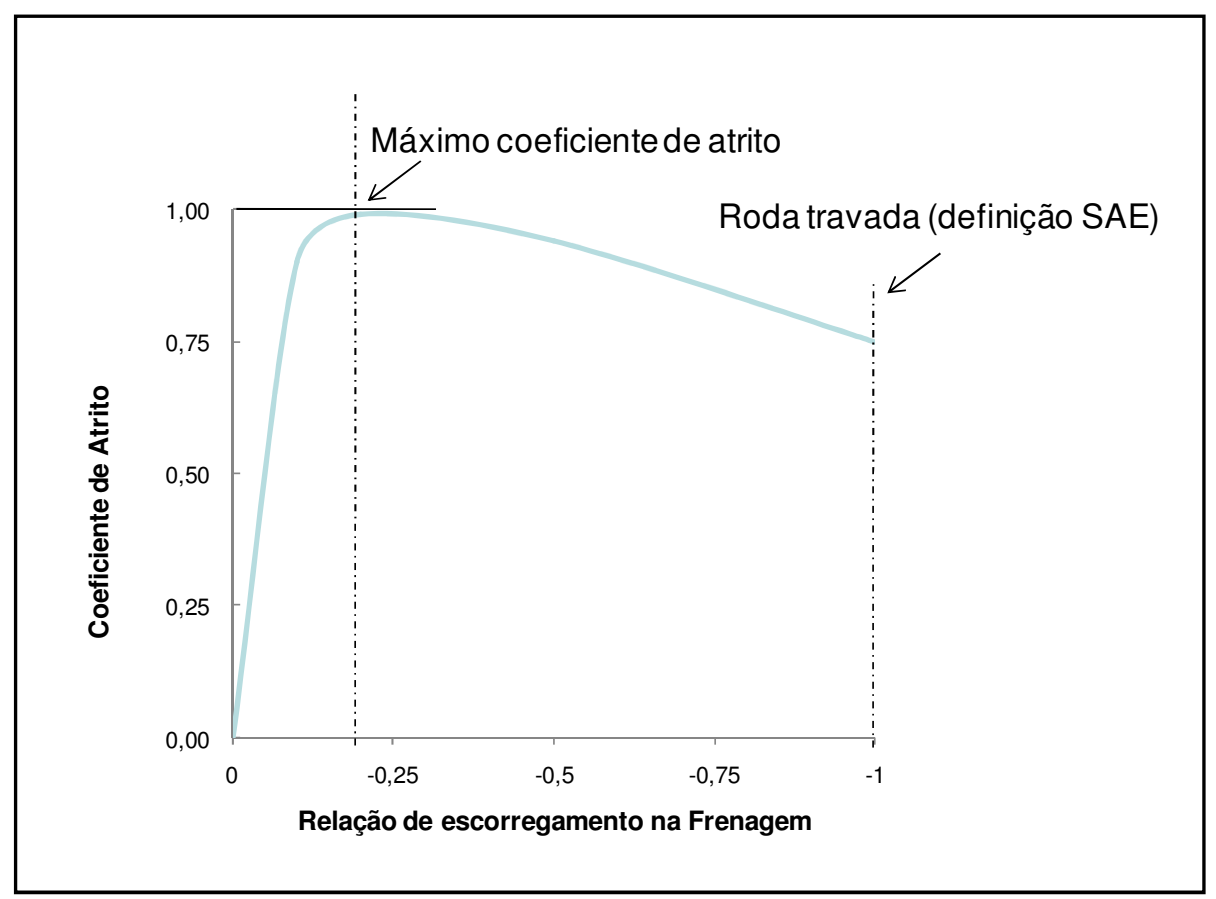

Figura 10: Escorregamento em função da força de frenagem (Viana (2006), apud Milliken (1995)).

A força máxima passível de ser aplicada ao pavimento é reduzida quando o véiculo está em uma manobra de curva. Ao realizar uma curva de raio constante o veículo transmite ao pavimento uma força conhecida por força centrífuga, que mobiliza uma parcela do atrito lateral disponível na superfície de contato pneumático-pavimento. Quando isto acontece ocorre uma redução no coeficiente de atrito máximo que o veículo pode utilizar na direção do movimento, cuja relação pode ser expressa por uma representação matemática conhecida por elipse de aderência, que estabelece a força máxima longitudinal disponível para cada valor de força lateral aplicada, como mostra a Figura 11. 


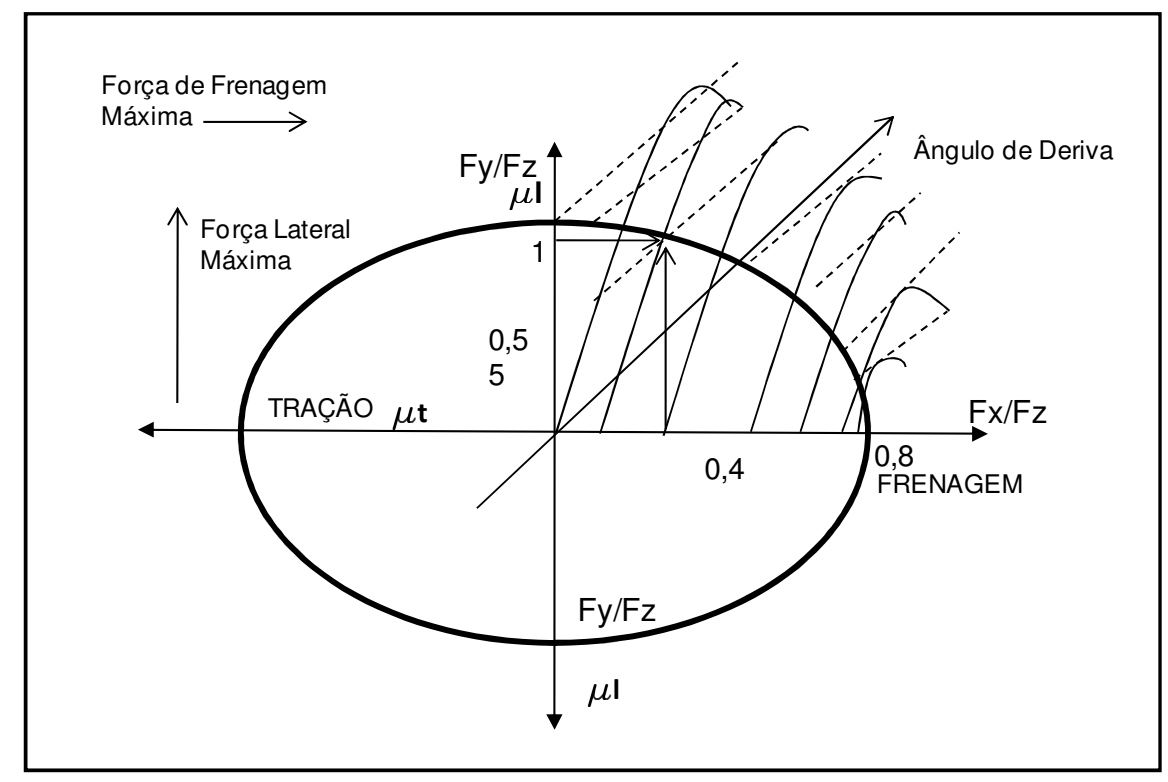

Figura 11: Elipse de Aderência (Canale, 1998).

Superfícies de rolamento possuem diferentes níveis de aderência, seja pelas diferenças entre os materiais que a constituem ou pelas condições em que se dá o tráfego, com presença de óleo ou lâmina d'água. Como dito anteriormente, a força máxima de atrito depende das condições de carga sobre o eixo que executa a frenagem, sendo assim diferentes também as situações de frenagem de um veículo vazio ou carregado.

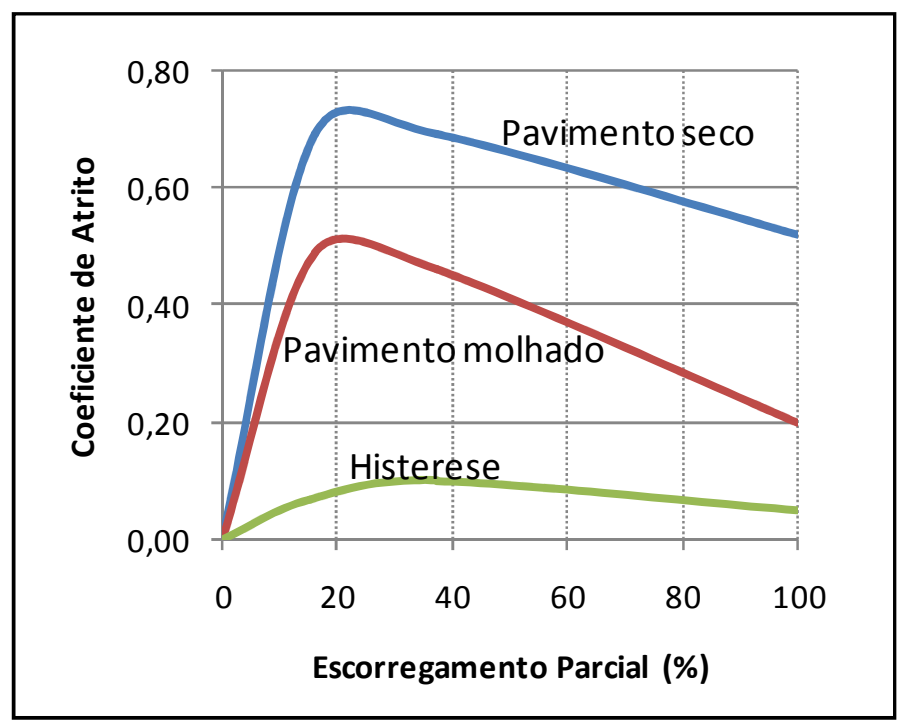

Figura 12: Coeficiente de atrito em função do escorregamento parcial na frenagem (Gillespie, 1992). 
Vista a importância da correta determinação do coeficiente de atrito disponível para realizar uma operação de frenagem de emergência, faz-se necessário abordar a capacidade que o veículo possui de mobilizar o atrito disponível. Outro conceito associado é o de "passeio do centro de gravidade", que em linhas gerais considera as variações de carga aplicada sobre os eixos devido a dinâmica do movimento. Canale (1991) estudou este fenômeno, que é discutido na seção 2.5 sobre estabilidade e controle veicular.

O sistema de freios "Antilock brake system" ou ABS impede o travamento prematuro das rodas em um manobra de frenagem, pois os pneus quando solicitados longitudinalmente perdem coeficiente de atrito lateral, e qualquer tentativa de manobra lateral pode travá-los. Se as rodas da frente, responsáveis pela dirigibilidade do veículo travarem, o veículo fica desgovernado. Se as rodas traseiras travarem o veículo perderá sua estabilidade direcional, podendo rodar na pista. Desta forma o projeto dos freios deve evitar o travamento das rodas, o que é mais difícil de ser evitado em veículos comerciais que possuem grande variedade de carregamento.

Faz-se necessário inserir neste momento o contexto de Distância de Visibilidade e Parada, adotado pelos manuais de projeto da AASHTO, AUSTROADS, DNER e TAC. Compreende a distância percorrida pelo veículos durante o tempo de percepção e reação do condutor, tempo de acionamento efetivo do sistema de freios (pressurização do sistema hidráulico ou pneumático) e tempo de frenagem até a parada completa do veículo.

A ASSHTO (2004) propõe a Equação 16 para cálculo da Distância de Visiblidade e Parada:

$$
D=0,078 \cdot V \cdot t_{r}+\frac{V^{2}}{254 *\left[\left(\frac{a}{9,81} \pm 0,01 * G\right)\right]}
$$

em que:

$\mathrm{D}=$ distância de visibilidade e parada $(\mathrm{m})$

$V=$ velocidade do veículo $(\mathrm{km} / \mathrm{h})$ 
$\mathrm{t}_{\mathrm{r}}=$ tempo de percepção e reação do condutor (s)

$\mathrm{a}=$ aceleração $\left(\mathrm{m} / \mathrm{s}^{2}\right)$

$\mathrm{i}$ = inclinação da pista ( $\mathrm{m} / \mathrm{m}$ ou \%)

Os parâmetros 0,078, 254 e 0,01 referem-se à conversão de unidades; o parâmetro 9,81 à aceleração da gravidade.

O Manual do DNER (1999), assim como os da TAC (1999) e AUSTROADS (2002), utiliza equações equivalentes, semelhante ao proposto pela AASHTO até o Manual de 1994, utilizando o parâmetro $f$, referente ao fator de atrito e admitindo um tempo de percepção e reação de 2,5 segundos $^{14}$, conforme mostra a Equação 17 (PEREIRA NETO, 2007).

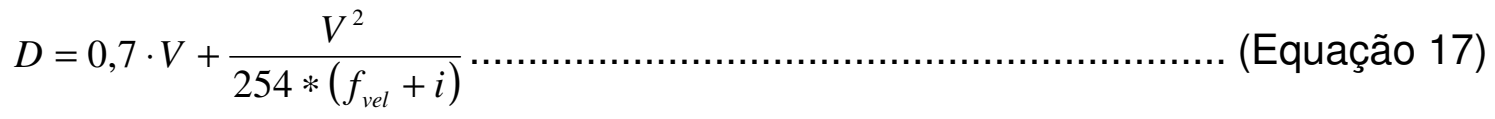

em que:

$$
\begin{aligned}
& D=\text { distância de visibilidade e parada }(\mathrm{m}) \\
& \mathrm{V}=\text { velocidade do veículo }(\mathrm{km} / \mathrm{h}) \\
& \mathrm{f}_{\text {vel }}=\text { fator de atrito, estabelecido para velocidade considerada } \\
& \mathrm{i}=\text { inclinação da pista }(\mathrm{m} / \mathrm{m} \text { ou \%) }
\end{aligned}
$$

Os parâmetros 0,7 e 254 referem-se à conversão de unidades.

Widmer (2002) sugere que o modelo da AASHTO de 1994 e atualmente adotado pelo DNIT deve ser complementado com um fator de eficiência de rendimento do sistema de freios $\left(\eta_{\mathfrak{f}}\right)$, cujo valor sugerido é $0,60^{15}$, para que a geometria da estrada associada a uma determinada velocidade de projeto ofereça condições seguras de tráfego às CVCs, o que leva à formulação da Equação 18.

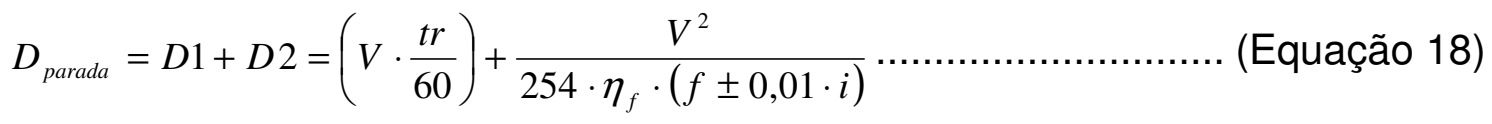

em que:

\footnotetext{
${ }^{14}$ Além do tempo de percepção e reação, para veículos longos, também deve ser analisado o tempo para resposta do sistema de freios, devido à pressurização do sistema até o acionamento de todos os conjuntos de freio.

${ }^{15}$ Canale et al (2005) reforçam a necessidade da aplicação de um fator de eficiência análogo.
} 
$D$ = distância de visibilidade e parada $(m)$

D1 = distância percorrida durante o tempo de reação $(m)$

D2 = distância de frenagem $(m)$

$\mathrm{V}=$ velocidade do veículo $(\mathrm{km} / \mathrm{h})$

$\eta_{f}=$ rendimento do sistema de freios do veículo

$f=$ coeficiente de atrito pneu-pavimento

$\mathrm{i}$ = inclinação da pista $(\mathrm{m} / \mathrm{m}$ ou \%)

$t_{r}=$ tempo de percepção e reação do condutor (s)

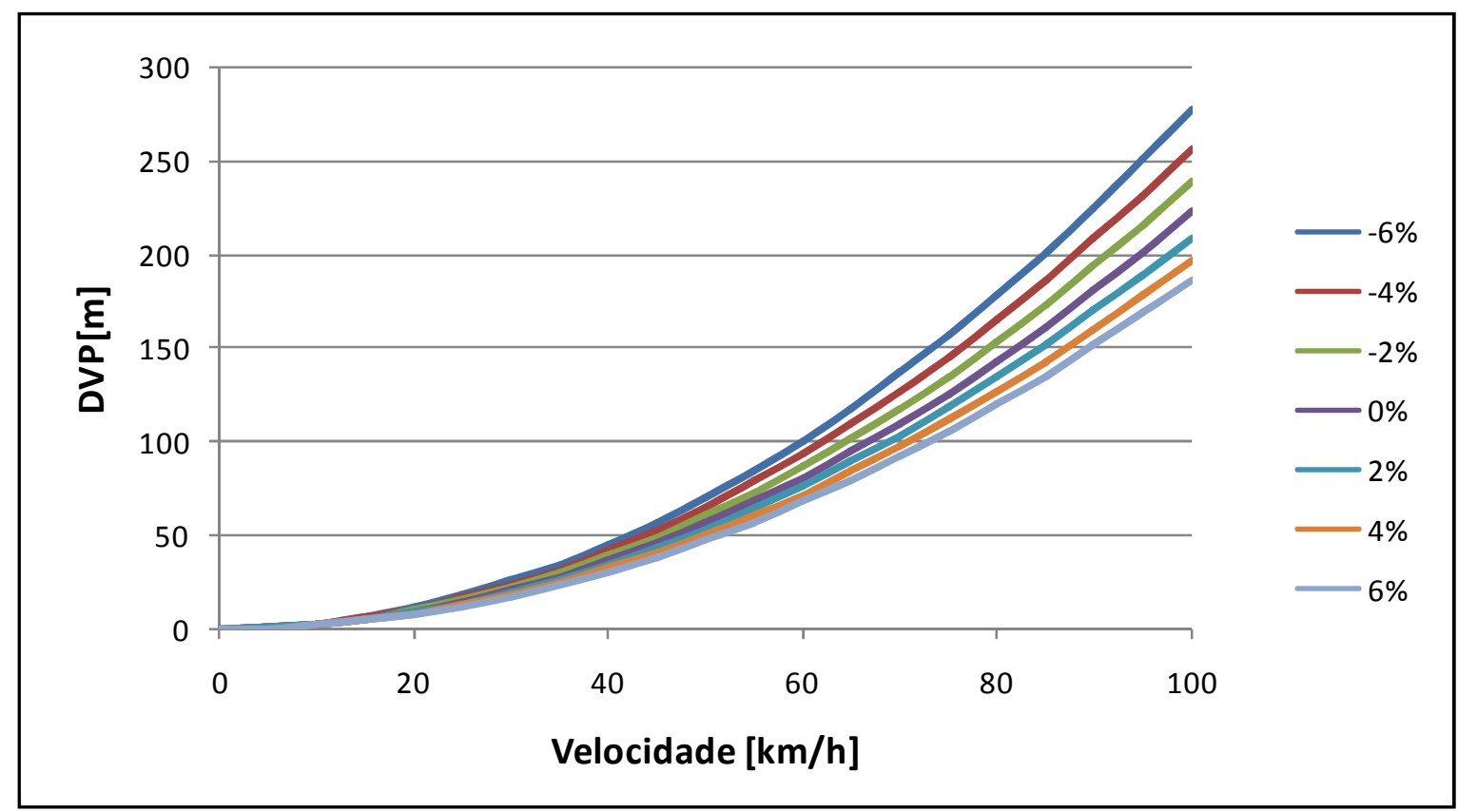

Figura 13: Distâncias de visibilidade e parada $\left(t_{r}=2,5 s ; \eta_{f}=0,60 ; f=0,30\right)$.

\subsubsection{Normas e regulamentações}

A certificação do sistema de freios é realizada atualmente para o sistema de freio, e não para a composição veicular. Como uma mesma combinação de veículos de carga pode utilizar diferentes tipos de sistemas de freios, a certificação deveria ocorrer para a composição (CVC) e não para os freios.

Devido à complexidade que envolve a operação de frenagem de caminhões e CVCs, por possuírem grande variabilidade em seus sistemas de freio, trafegarem por vias com as mais variadas qualidades de revestimento e pavimento, possuírem pneumáticos com características diferentes em uma mesma compo- 
sição, podendo ou não utilizar o sistema ABS em um ou mais conjunto de freio, e ainda transportar cargas com densidades variáveis e em alguns casos permitir o levantamento de eixos, recomenda-se que a certificação de veículos de carga seja feita mediante normas regulamentadoras, como especificam as NBR 14353 e NBR 14354, que estabelecem requisitos mínimos para espaço de parada, desaceleração média, seqüência de travamento de eixos, eficiência de frenagem, força e estabilidade no pedal de freio e controle de "fading".

Outro ponto importante para garantir a segurança da operação de veículos pesados seria a obrigatoriedade da utilização do sistema de freios ABS, que impedem o travamento prematuro dos pneumáticos.

Considerando todas as variáveis que influem na frenagem de emergência de veículos de carga, a evolução dos manuais de projeto, e as normas regulamentadoras apresentadas, sugere-se a obrigação de ensaios de frenagem para certificação de tráfego de combinações de veículos de carga e a revisão dos manuais de projeto para considerarem a heterogeneidade dos veículos em suas diretrizes de projeto geométrico de rodovias.

\section{NBR14353 (01/08/1999)}

"Veículos rodoviários - Veículos motorizados equipados com sistema antibloqueio de frenagem - Medida do desempenho do freio". Estabelece exigências de desempenho para sistemas de freio $A B S$ instalados em veículos rodoviários, e determina que unidades tratoras e reboques (carregados) com sistema de freio a ar comprimido devem satisfazer as exigências da NBR 14354.

\section{NBR14354 (01/08/1999)}

"Veículos rodoviários - Distribuição de frenagem entre os eixos veiculares e requisitos para compatibilidade entre veículos rebocadores e reboques". Especifica a distribuição de frenagem entre os eixos veiculares e os requisitos para compatibilidade entre os veículos de tração e os rebocados. 


\subsection{Sobrelargura}

Veículos combinados possuem manobrabilidade inferior e restrições de gabarito maiores que automóveis. As restrições de gabarito são as incompatibilidades geométricas da via com as manobras dos veículos, como área disponível de manobra em interseções, sobrelargura em trechos curvos de rodovias e altura de pontes e viadutos. Tais incompatibilidades aparecem devido à complexidade do modo como veículos de carga executam suas manobras em relação aos automóveis e ao gabarito utilizado no projeto de interseções e rodovias.

O longo comprimento das composições provoca efeitos operacionais indesejáveis, como 0 arraste $^{16}$, que limita a capacidade de conversão em interseções, avançando sobre faixas contíguas ou sobre guias e sarjetas. Em ambos os casos o veículo interfere na capacidade das vias, tornando-se freqüentemente uma obstrução ao tráfego (Russo, 1995). As manobras são complexas devido à variabilidade de dimensões, articulações (posição e tipo) e tipos de conjuntos de eixos permitidos pela legislação vigente.

Veículos mais pesados, por possuírem mais eixos e articulações, apresentam normalmente piores condições de manobrabilidade, devendo, portanto, orientar projetos de sobrelarguras.

Para definir o modo como veículos complexos realizam suas manobras, foram desenvolvidos modelos para representar e prever essas operações. Os modelos permitem estimar a área ocupada pelos veículos nas conversões e a folga lateral demandada em trechos curvos de rodovias.

Para que ocorra o fenômeno de arraste positivo, tendência da traseira do veículo se mover para dentro da curva, a literatura recomenda que a velocidade do veículo seja inferior a $16 \mathrm{~km} / \mathrm{h}$. Para velocidades mais altas e mesmo raio de curva a aceleração lateral é mais alta, o que diminui o efeito de arraste. (Winkler

\footnotetext{
${ }^{16}$ Arraste: deslocamento dos eixos traseiros de uma composição em direção ao centro da curva de raio restrito. Aumenta para veículos com maior distância entre eixos e para curvas com raios menores (Pereira Neto, 2007)
} 
et al. 1987, apud Russo 1995). Este fenômeno, chamado arraste negativo, ocorre em trechos curvos de rodovias, em que a aceleração lateral tende a mover a traseira do veículo para fora da curva.

Os tipos de articulação mais utilizados pelos fabricantes são: A-dolly, Bdolly, C-dolly.

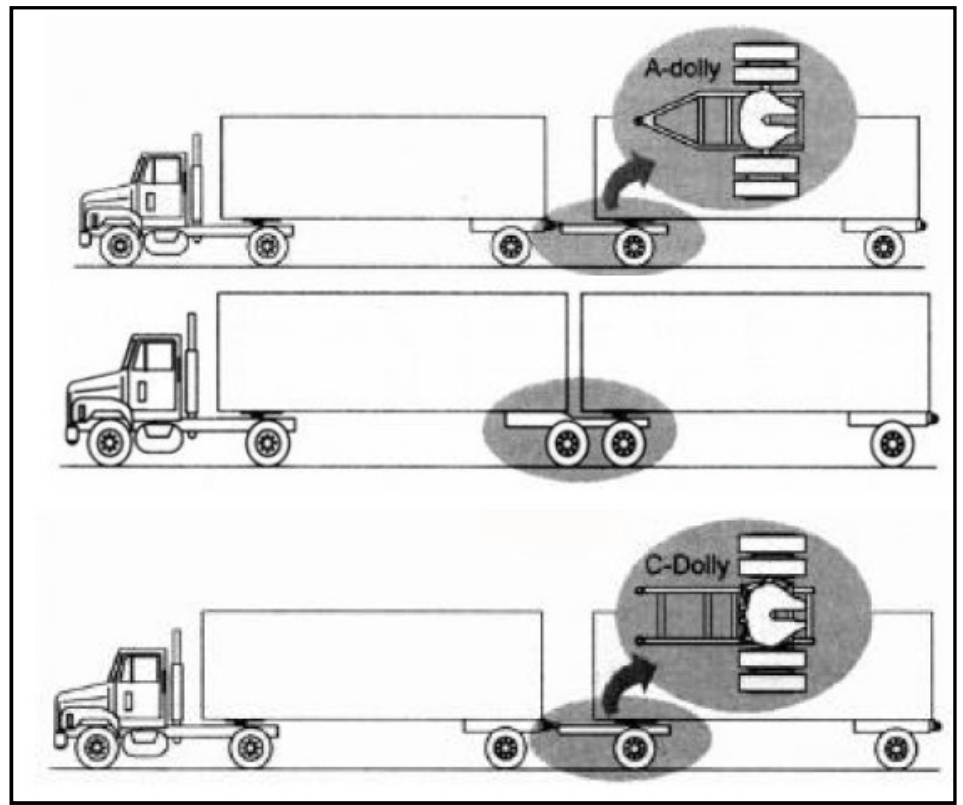

Figura 14: Articulações A, B e C-Dolly, entre veículos de carga

\subsubsection{Arraste em condições de regime permanente}

Descreve a trajetória de um veículo em estado de arraste permanente, ou seja, o centro do eixo traseiro da unidade tratora e os demais eixos da configuração passam a percorrer trajetórias circulares concêntricas ao raio da curva percorrida pelo centro do eixo dianteiro (Fancher \& Mathew, 1997).

Como ilustra a Figura 15, a área ocupada pelo veículo pode ser determinada com o auxílio da Equação 22. 


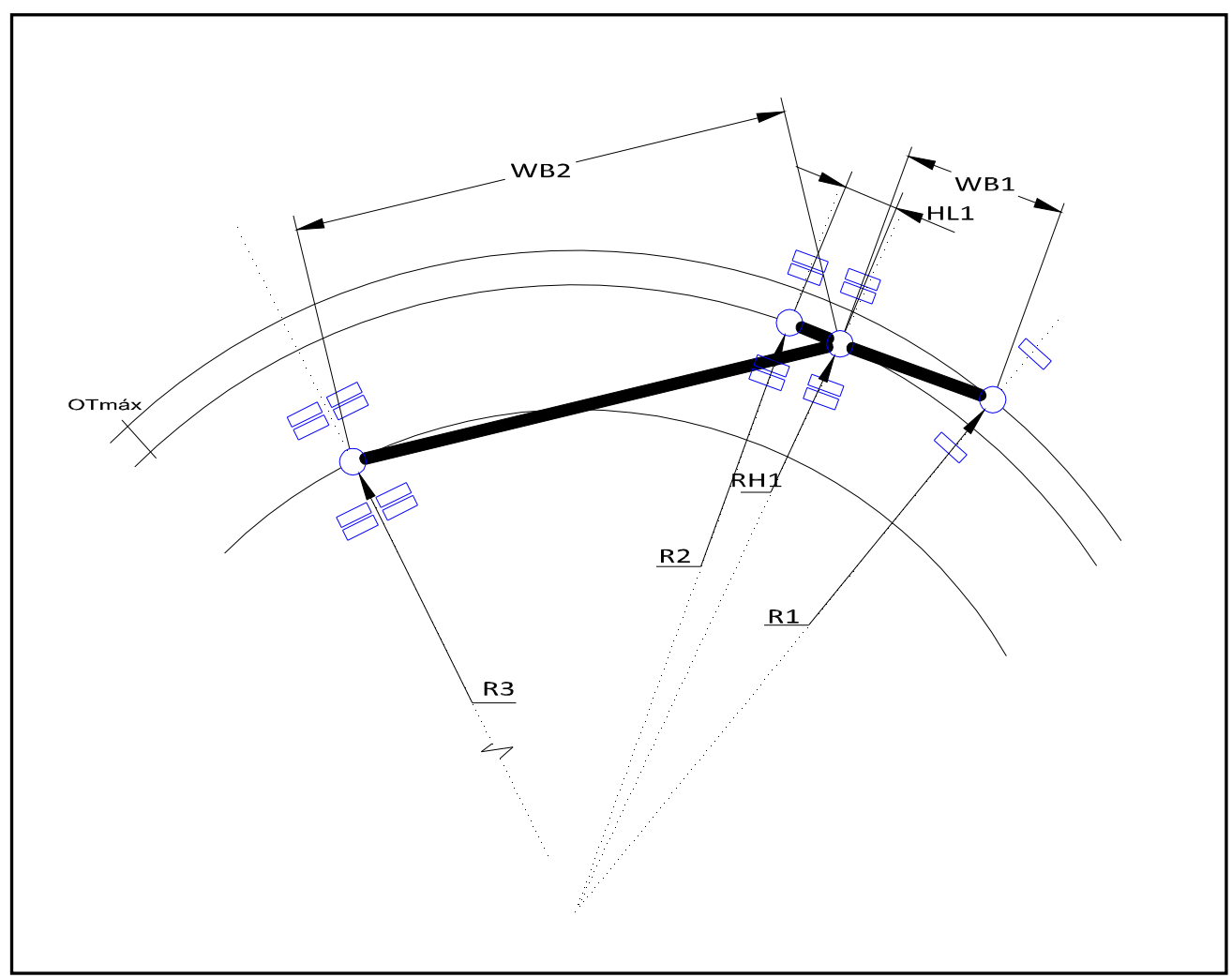

Figura 15: Trajetória em regime permanente (adaptado de Fancher \& Mathew, 1987)

$$
\begin{aligned}
& R 2^{2}=R H 1^{2}-W B 1^{2} \\
& R H 1^{2}=R 2^{2}+H L 1^{2} \\
& R 3^{2}=R H 1^{2}-W B 2^{2} \\
& O T_{\text {máx }}=R 1-R 3 \ldots \ldots .
\end{aligned}
$$

em que:

R1 = raio referente ao eixo dianteiro do cavalo mecânico $(\mathrm{m})$

$\mathrm{R} 2$ = raio referente ao eixo traseiro do cavalo mecânico $(\mathrm{m})$

$\mathrm{R} 3$ = raio referente ao eixo traseiro do semi-reboque $(\mathrm{m})$

$\mathrm{RH} 1$ = raio referente ao pino rei da quinta-roda $(\mathrm{m})$

HL1 = excentricidade do pino rei, distância entre a suspensão traseira da unidade tratora e a articulação $(\mathrm{m})$

WB1 = distância entre eixos do cavalo mecânico $(\mathrm{m})$

WB2 = distância entre eixos do semi-reboque (m)

$\mathrm{OT}_{\text {máx }}=$ arraste máximo constante $(\mathrm{m})$ 


\subsubsection{Western Highway Institute - WHI}

O Manual do DNER (1999), que segue as orientações propostas pela AASHTO, determina equações para o cálculo do arraste negativo em trechos curvos. No caso do estudo de CVCs, o WHI-SAE, assim como o método do arraste em estado uniforme, admite a condição de curva em regime estacionário (permanente) e propõe a utilização da Equação 23 para cálculo da sobrelargura máxima, que substitui a formulação proposta no referido manual (WIDMER, 2002).

$$
G_{C}=L_{V}+\left(R-\sqrt{R^{2} \pm \sum_{i-1}^{n} E_{i}^{2}}\right)
$$

em que:

$\mathrm{G}_{\mathrm{C}}=$ gabarito estático do veículo de projeto em curva $(\mathrm{m})$

$L_{v}=$ largura física do veículo de projeto $(\mathrm{m})$

$\mathrm{R}=$ raio da curva em relação ao centro do eixo dianteiro $(\mathrm{m})$

$E_{i}=$ i-ésima distância entre pontos notáveis do veículo $(m)$, medida a partir do ponto médio do eixo dianteiro do veículo trator e formando segmentos de reta que afetam a curva de arraste. $O$ termo $E_{i}^{2}$ recebe sinal positivo quando o i-ésimo segmento contribui para o aumento da sobrelargura, e negativo caso contrário.

$\mathrm{n}$ = número de segmentos notáveis da composição

Segundo HEALD (1986), esta é a formulação mais simples e a mais utilizada, pois pode ser aplicada a veículos simples e combinados. Para veículos unitários, a Equação 23 permite a formulação da Equação 24, fórmula também adotada pela SAE.

$$
O T_{\max }=\sqrt{W B^{2}+\left(\sqrt{T R^{2}-W B^{2}}-H T\right)^{2}}-\sqrt{T R^{2}-W B^{2}}+H T
$$

em que:

$\mathrm{TR}=$ raio da curva em relação à roda dianteira externa $(\mathrm{m})$

WB = distância entre eixos $(m)$ 
$\mathrm{HT}$ = metade da medida da bitola do eixo dianteiro $(\mathrm{m})$

$\mathrm{OT}_{\text {máx }}=$ arraste máximo constante $(\mathrm{m})$

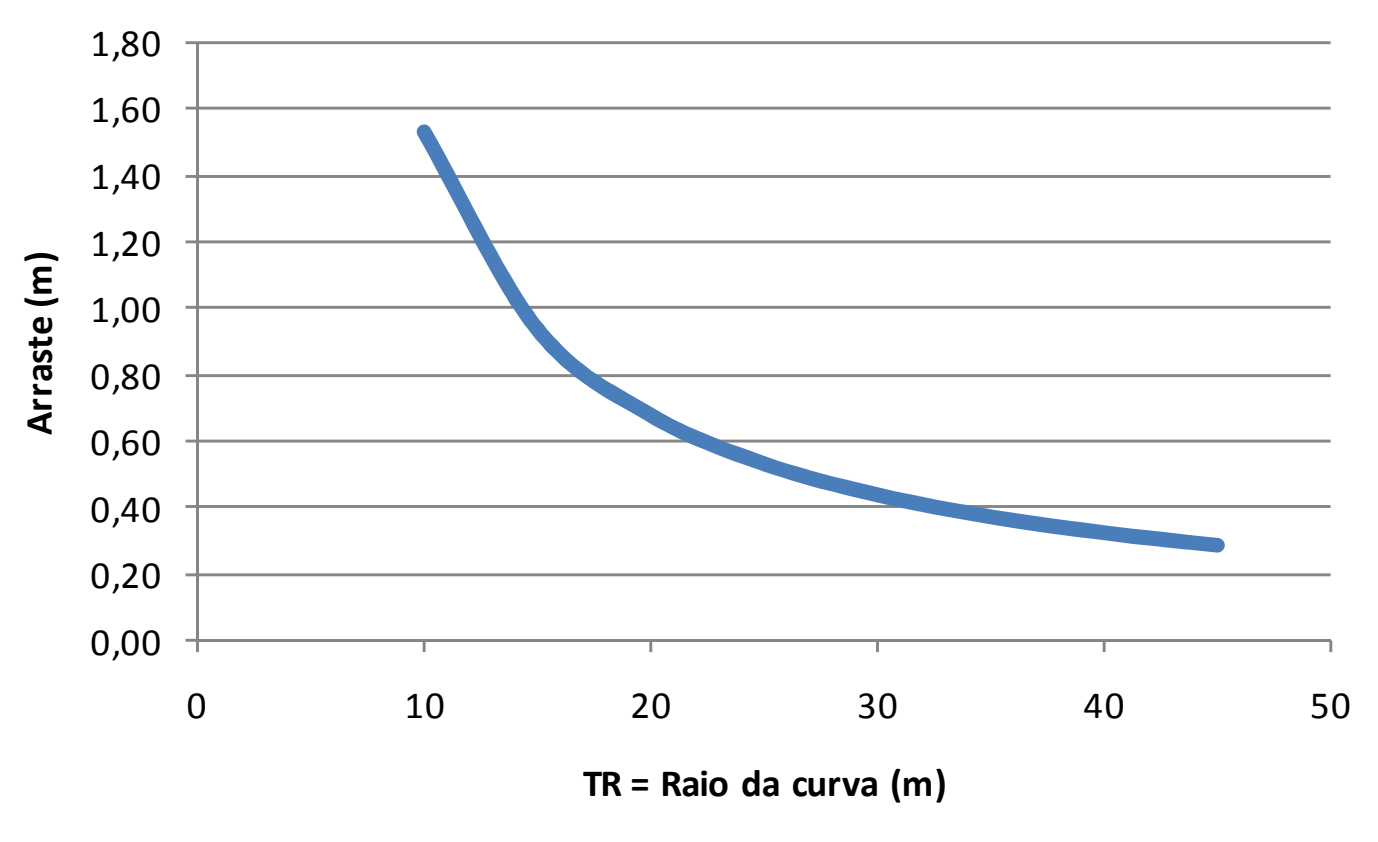

Figura 16: Arraste em função do raio da curva (WB=5m; $H T=1,25 m)$.

A Figura 16 apresenta o resultado gráfico da aplicação da Equação 24 a um veículo unitário hipotético. Observa-se que ao aumentar o raio das curvas o arraste diminui, o que significa que curvas com raios menores são mais restritivas.

Existem simuladores computacionais que permitem determinar a área ocupada por um veículo em uma conversão, uma relação de softwares é apresentada em Russo (1995), sendo o AutoTurn um dos recomendados para esse tipo de aplicação e também por estar disponível aos pesquisadores do Departamento de Transportes da Escola de Engenharia de São Carlos. 


\subsection{3. "Simulação por curva tractrix" e software AutoTurn}

Admite que a trajetória do centro do eixo dianteiro da unidade tratora segue uma trajetória circular pré-definida, e a trajetória do centro do eixo traseiro da unidade tratora é a tractrix à primeira curva. A trajetória da quinta-roda é usada para determinar a tractrix do centro do eixo traseiro do semi-reboque, que é função das condições físicas geradas a partir do movimento do eixo do semi-reboque em direção ao ponto de articulação do cavalo mecânico, sendo que a distância entre ambos permanece constante. Com esse raciocínio, por iteração, resolve-se o restante. Resumidamente, é a condição da cinemática física, que assume que o ponto rebocado se move em direção ao ponto que o reboca (GARLICK et al, 1993).

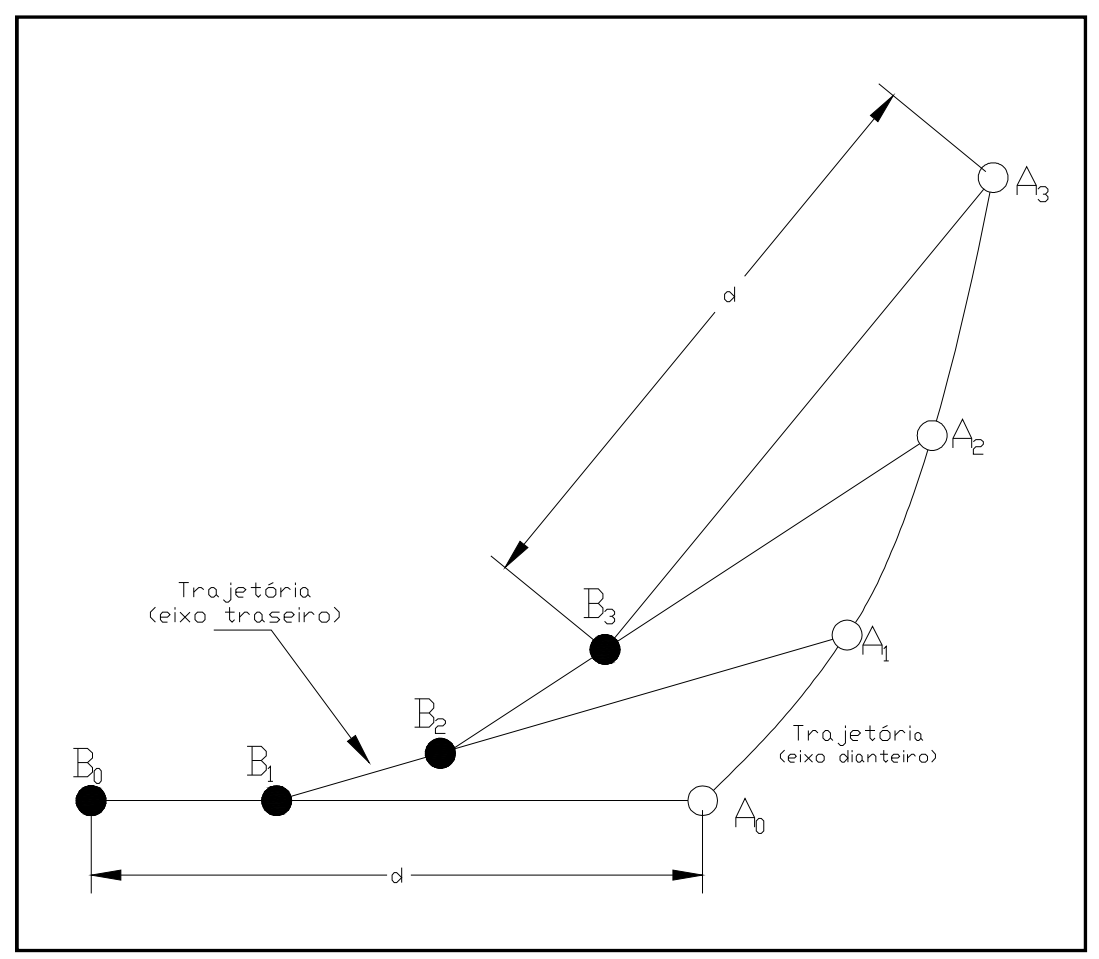

Figura 17: Construção da curva tractrix.

O algoritmo para cálculo da curva tractrix pode ser resumido nos seis passos descritos a seguir. 
1) Definir o ponto que reboca $(A)$, o ponto rebocado $(B)$ e a trajetória. $A$ trajetória do veículo será os pontos $A 0, A 1, A 2$, etc... e B0, B1, B2, etc. $A$ distância (d) entre A e B é duas articulações consecutivas do veículo

2) Dividir a trajetória do ponto que reboca $(A)$ em passos idênticos

3) Desenhar uma linha reta entre A e B, e determina-se A0 e B0

4) Dar um passo na trajetória e marcar A1

5) A interseção do círculo de raio "d" e centro A1 com a linha A0B0 define B1

6) Iteração das seções 4 e 5 até fim da trajetória.

Pereira Neto (2007) estudou a compatibilidade das sobrelarguras entre os veículos de projeto propostos pelo DNER, as classes de rodovia e o tipo de terreno. Entre outras conclusões, os resultados por ele obtidos indicam que:

1) Os veículos mais complexos enfrentam restrições maiores à medida que o padrão técnico da rodovia diminui, uma vez que são permitidos raios de curvas menores e faixas de tráfego mais estreitas;

2) Veículos com maiores comprimentos totais não implicam necessariamente maiores valores de sobrelarguras requeridas. De modo geral, veículos com mais pontos de articulação e menores distâncias entre eixos da unidade tratora e das unidades rebocadas exigem menores sobrelarguras;

3) Combinações tipo cavalo mecânico e semi-reboque(s) requerem sobrelarguras maiores do que combinações tipo caminhão-plataforma mais reboque (romeu-e-julieta) de mesmo comprimento.

Concluiu que há condições restritivas ao tráfego tanto de veículos comerciais unitários como de CVCs, sendo importante uma mudança no critério de escoIha do veículo de projeto para determinação de sobrelarguras. A Tabela 2 apresenta o registro de ocorrências de uso de acostamento e incompatibilidades com as vias estudadas por Pereira Neto (2007). 
Tabela 2: Compatibilidade das sobrelarguras em curvas horizontais considerando as simulações de alguns veículos de projeto (Pereira Neto, 2007)

\begin{tabular}{|c|c|c|}
\hline \multirow{2}{*}{$\begin{array}{c}\text { VEÍCULO DE PROJETO } \\
\text { SIMULADO' }\end{array}$} & \multicolumn{2}{|c|}{ COMPORTAMENTO DOS DEMAIS VEÍCULOS } \\
\hline CO (DNER) & $\begin{array}{c}\text { Número de Ocorrências de Uso } \\
\text { de Acostamento }\end{array}$ & $\begin{array}{c}\text { Número de Ocorrências de In- } \\
\text { compatibilidade }\end{array}$ \\
\hline O (DNER) & 77 & 13 \\
\hline SR (DNER) & 50 & 7 \\
\hline 12S3B3 & 31 & 6 \\
\hline 11S1 & 19 & 2 \\
\hline 12S2B2 (26m) & 10 & 1 \\
\hline 11S2 (20m) & 9 & 1 \\
\hline 12S2A2S2 & 7 & 0 \\
\hline 11S2 (22,4m) & 2 & 0 \\
\hline
\end{tabular}

2.4.4. Normas e regulamentações

Resolução № 213 DE 13/11/2006 (BRASIL, 2006c)

Autoriza o trânsito de veículos transportadores de contêineres, com altura superior a 4,40m e inferior a 4,60m, mediante Autorização Especial de Trânsito AET. No caso de combinação de veículos a AET é fornecida somente à(s) unidade(s) rebocada (s).

Resolução № 68 DE 23/09/1998 (BRASIL, 1998)

"Requisitos de segurança necessários à circulação de Combinações de Veículos de Carga- CVC"

Em linhas gerais, a resolução estabelece:

1) necessidade de AET para CVCs com os limites de PBTCmáx = 74t e comprimento máximo de $30 \mathrm{~m}$

${ }^{17}$ Para a nomenclatura de caminhões e CVCs, foi utilizada a proposta por Widmer (2008) 
2) limites de peso por eixo, CMT e PBTC

3) sistema de freios conjugados entre as unidades rebocadas e a unidade tratora

4) sinalização apropriada

5) indicação do trecho e quilometragem da operação

6) unidade tratora com tração dupla (liberação com tração simples somente com estudo técnico específico)

7) faixa adicional nos seguimentos em rampa com aclive e comprimento superiores a $5 \%$ e $500 \mathrm{~m}$ respectivamente.

8) horário de circulação: 06:00 e às 18:00 hs

9) Velocidade máxima de $60 \mathrm{Km} / \mathrm{h}$

O Artigo 32 do DNER (1973) trata do problema da sobrelargura e propõe a Equação 25 como diretriz de projeto.

$$
s=n\left(R-\sqrt{R^{2}-b^{2}}\right)+\frac{V}{10 \sqrt{R}}
$$

em que:

$$
\begin{aligned}
& \mathrm{s}=\text { sobrelargura }(\mathrm{m}) \\
& \mathrm{n}_{\text {faixas }}=\text { número de faixas de tráfego } \\
& \mathrm{R}=\text { raio de curva }(\mathrm{m}) \\
& \mathrm{V}=\text { velocidade do veículo }(\mathrm{km} / \mathrm{h}) \\
& \mathrm{b}=\text { distância entre eixos do veículo }(\mathrm{m})
\end{aligned}
$$

\section{Diretiva 85/3/EEC}

Conhecida como restrição do "Círculo europeu", determina que o veículo seja capaz de executar uma conversão com características geométricas definidas, raio interno $5,3 \mathrm{~m}$ e raio externo $12,5 \mathrm{~m}$. (Schurrman, 1989) 


\subsection{Estabilidade e controle}

As CVCs possuem comportamento dinâmico lateral mais complexo que os veículos simples. Esses veículos possuem grande variabilidade nas condições de carregamento, massa transportada, momento de inércia, posição do centro de gravidade, e constantes mudanças na transferência de carga entre eixos e pneumáticos. Os pontos de conexão entre as unidades de um conjunto são os responsáveis pela transmissão das forças associadas a acelerações laterais e longitudinais. Desta forma, veículos articulados possuem problemas adicionais de estabilidade e movimentos instáveis característicos, razão pela qual demandam modelos mais complexos para representarem seu comportamento e permitirem estudos acurados de estabilidade.

Tabela 3: Exemplos de combinações de veículos de carga (Widmer, 2008)

\begin{tabular}{|c|c|c|}
\hline TIPO & PBTC & Representação Pictográfica \\
\hline U11 & 16 & \\
\hline U12 & 23 & \\
\hline 11S1 & 36 & \\
\hline 11S1B1 & 36 & \\
\hline 11S1A1S1 & 45 & \\
\hline $\begin{array}{c}11 S 2 \\
(20 \mathrm{~m} \text { e } \\
22,4 \mathrm{~m})\end{array}$ & 33 & 010 \\
\hline $11 S 3$ & 41,5 & চাচাত \\
\hline 12S2 & 40 & \\
\hline $12 \mathrm{S3}$ & 48,5 & \\
\hline $\begin{array}{c}12 \mathrm{~S} 2 \mathrm{~B} 2 \\
(20 \mathrm{~m} \text { e } 26 \mathrm{~m})\end{array}$ & 57 & \\
\hline
\end{tabular}


Horta Gutiérrez (1999) apresenta extensa revisão bibliográfica sobre estudos de estabilidade de veículos articulados e estende a metodologia do equilíbrio estático de forças, também utilizada no modelo de tração apresentado na seção 2.1, aos movimentos laterais e rotacionais do veículo. Desta forma, a Equação 1 pode ser reescrita para representar os movimentos longitudinais, laterais e verticais, como mostra a Equação 26.

$\sum F_{i}=M \cdot a_{i}$ .(Equação 26)

em que:

$$
\begin{aligned}
& F_{i}=\text { força aplicada na direção } i(N) \\
& M=\text { massa do veículo }(k g) \\
& a_{i}=\text { aceleração resultante na direção } i\left(\mathrm{~m} / \mathrm{s}^{2}\right)
\end{aligned}
$$

A Figura 18 ilustra a aplicação da Equação 26 a um veículo unitário com um reboque acoplado (U12A1S1).

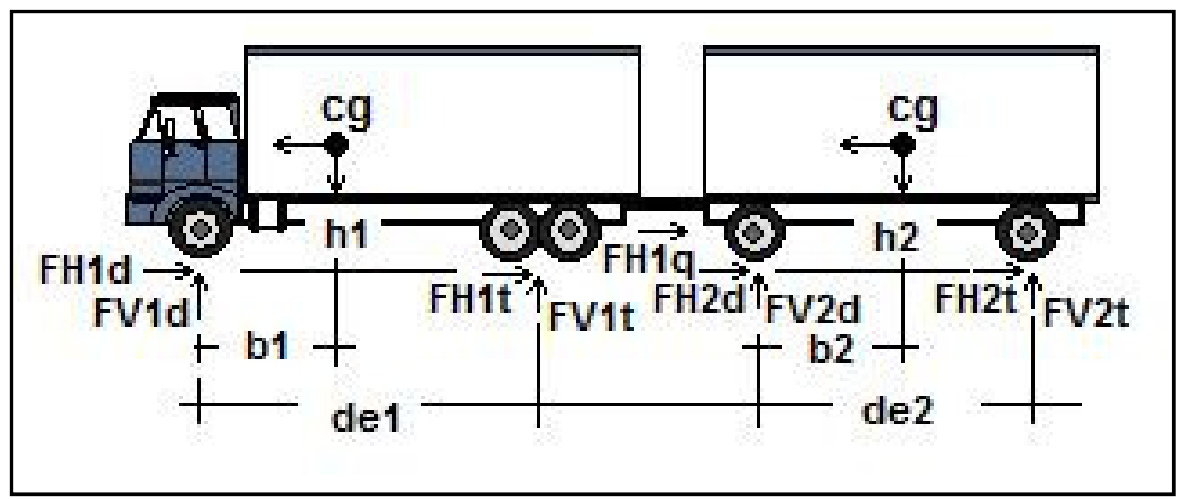

Figura 18: Equilíbrio de forças (Widmer, 2002).

Widmer (2002) desenvolveu a Equação 26 para um veículo com engate tipo quinta roda, com transferência de cargas verticais de uma unidade para a outra, e obteve as Equações 27 e 28. 
FV1t. de1 + M1 a.h1 $-\mathrm{FH} 1 \mathrm{q} \cdot \mathrm{hq} 1=\mathrm{FV} 1 \mathrm{q}(\mathrm{de} 1-\mathrm{dq} 1)+\mathrm{W} 1 \cdot \mathrm{b1}$ (Equação 27)

$F V 2 t \cdot d e 2+M 2 \cdot a(h 2-h q 1)+F H 1 q \cdot h q 1=W 2 \cdot b 2$ (Equação 28)

Para um engate tipo pino articulado ("boca de bagre") onde não ocorre transferência de cargas verticais de uma unidade para a outra, obteve a Equação 29, em que i é o número de cada veículo da CVC.

FVit. dei + Mi. a $\cdot$ hi + FHiq $\cdot$ hqi $=$ Wi. bi (Equação 29)

Analogamente, no sistema rotacional é possível estabelecer o equilíbrio entre a soma dos torques que atuam no veículo ao redor de um de seus eixos e o produto dos momentos de inércia rotacional pela aceleração rotacional ao redor do eixo de referência adotado, como mostra a Equação 30.

$\sum T_{i}=I_{i i} \cdot \alpha_{i}$ (Equação 30)

em que:

$$
\begin{aligned}
& T_{i}=\text { torque ao redor do eixo i }(N . m) \\
& \mathrm{l}_{i i}=\text { momento de inércia ao redor do eixo i }\left(\mathrm{m}^{4}\right) \\
& \alpha_{i}=\text { aceleração ao redor do eixo i }\left(\mathrm{m} / \mathrm{s}^{2}\right)
\end{aligned}
$$

A massa e os momentos de inércia ao redor de qualquer eixo podem ser determinados se conhecidas as condições de carregamento do veículo e suas dimensões. Uma vez conhecidas as forças e torques que atuam no veículo, torna-se possível calcular as acelerações resultantes.

O carregamento em veículos comerciais tem grande relevância na massa total do veículo e nas propriedades de inércia. A carga influi em toda a dinâmica veicular, e sua distribuição entre os eixos da composição está associada à capacidade do pneumático de desenvolver forças laterais e/ou longitudinais, estrutura que define as condições de estabilidade do veículo. 
A seção 2.3 discute a interação entre pneumático e pavimento, e deixa evidente a importância da força vertical aplicada em cada pneumático para definir a capacidade do mesmo mobilizar atrito.

A técnica do "balanço estático" ou "passeio do centro de gravidade" pode ser aplicada a cada unidade de uma CVC para representar a variação da posição do centro de gravidade com a condição de carregamento do veículo. Canale (1991) utiliza esta técnica para avaliar o desempenho de um veículo de passeio. Fernandes (1994) aplica o mesmo conceito ao estudo da frenagem de uma CVC tipo 11S3 (cavalo mecânico de dois eixos e semi-reboque com três eixos em tandem). O resultado da aplicação desta técnica é um mapa de desempenho que mostra as possíveis distribuições de massa no veículo e a variação da posição do c.g. correspondente, como ilustra a Figura 19.

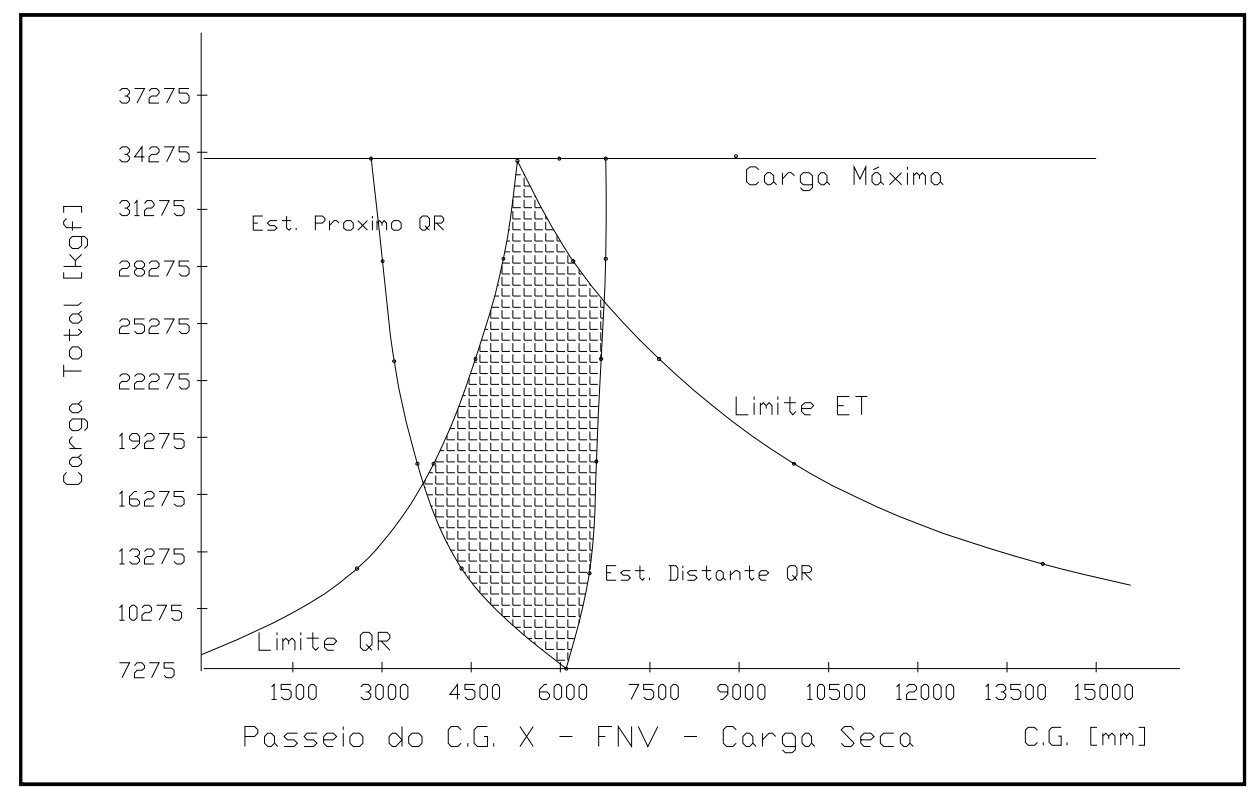

Figura 19: Passeio do c.g. longitudinal de um semi-reboque (adaptado de FERNANDES, 1994)

Desta forma, a posição do c.g. em cada operação irá definir os momentos de inércia para os eixos principais do veículo ${ }^{18}$, o que altera as condições de estabilidade do veículo. Outros fatores como alteração na distância entre eixos do veículo, permitida pela legislação e realizada após a fabricação do veículo, e le-

\footnotetext{
${ }^{18}$ Canale (1989) apresenta um método para definir a posição do c.g. baseado em pesagens diferenciais. Este método adota o sistema de coordenadas da norma SAE J670e (1976).
} 
vantamento de eixos, na tentativa de reduzir custos com desgaste de pneumático ou cobrança de pedágio ${ }^{19}$, também interferem na estabilidade do veículo.

Na prática, os veículos devem oferecer condições para trafegar com segurança com qualquer carregamento permitido pelo fabricante, mantendo a dirigibilidade do veículo ou handing, a estabilidade direcional e responder aos comandos efetuados pelo motorista, apresentando para isto sensibilidade suficiente na direção.

Na tentativa de prever o desempenho de veículos quanto a sua estabilidade, modelos mais simplificados foram desenvolvidos, com dois e três graus de liberdade.

O modelo com dois graus de liberdade (modelo da bicicleta) não considera a transferência de força vertical das rodas internas para as rodas do lado externo à curva do veículo em um movimento circular, a transferência de carga lateral e longitudinal, e os movimentos de rolagem e arfagem do veículo em relação a suspensão. Os pneus trabalham na região linear, com velocidade longitudinal constante, não considera também os efeitos aerodinâmicos e as influências do chassi e da suspensão.

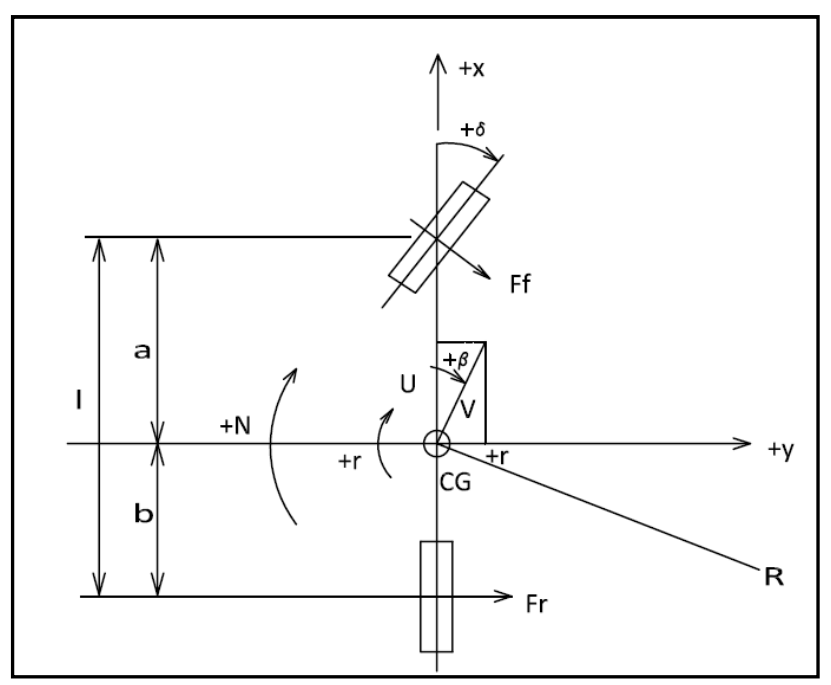

Figura 20: Modelo da bicicleta para estabilidade (Horta Gutierrez, 1999).

\footnotetext{
${ }^{19}$ A economia pode ser aparente, uma vez que o eixo que permanece apoiado trafegará com sobrecarga. Em alguns países a tarifação é efetuada segundo a categoria do veículo, e não pelo número de eixos em contato com o pavimento.
} 
O modelo com três graus de liberdade (Leonard Segel, 1956) considera o efeito da transferência de carga lateral, permitindo assim a redistribuição do peso do veículo, que por alterar a força normal em cada pneu altera as condições de estabilidade.

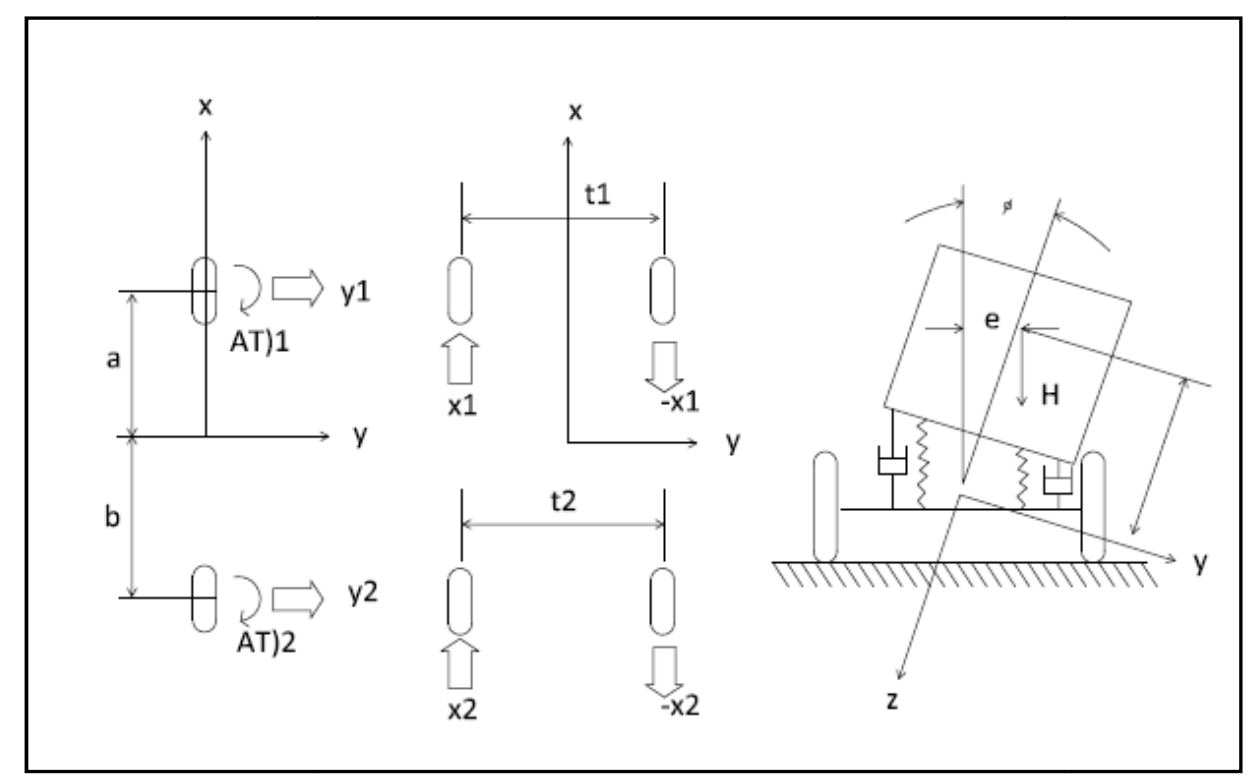

Figura 21: Modelo com três graus de liberdade para estabilidade (adaptado de Segel, 1956).

Existem ainda modelos de "regimes transitórios", que estudam 0 comportamento do veículo após um distúrbio (efeitos do amortecimento), para saber se os movimentos são amortecidos ou amplificados. Após o distúrbio o desempenho pode ser classificado em: estável, instável ou indiferente. A formulação matemática do amortecimento é extensa, complexa e foge ao escopo deste trabalho, assim serão discutidos apenas os fundamentos teóricos do problema. Perseguim (2005) pesquisou o tema em seu estudo sobre ride $e^{20}$ de veículos.

Estudos simplificados podem ser realizados para avaliar a estabilidade de veículos quanto ao tombamento e ao escorregamento em trechos curvos. A ASSHTO (2004) e o DNER - Departamento Nacional de Estradas e Rodagem

\footnotetext{
${ }^{20}$ Ride: comportamento da suspensão do veículo frente a perturbações.
} 
(atual DNIT) estabelecem a Equação 31 como critério de projeto para curvas horizontais, considerando para isso o limiar de escorregamento lateral do veículo.

$$
R_{\min }=\frac{V^{2}}{\left.127 \cdot\left(e_{\max }+f_{\text {lateral }}\right)\right)}
$$

em que:

$$
\begin{aligned}
& R_{\min }=\text { raio mínimo para curva circular }(\mathrm{m}) \\
& V=\text { velocidade do veículo }(\mathrm{km} / \mathrm{h}) \\
& \mathrm{e}_{\max }=\text { superelevação máxima da curva }(\%) \\
& \mathrm{f}_{\text {lateral }}=\text { fator de atrito lateral máximo admissível }
\end{aligned}
$$

O Apêndice I apresenta uma tabela com fatores de atrito lateral recomendados pelos manuais de projeto AASHTO (2004), TAC (1999), DNER (1999) e AUSTROADS (2002).

É possível expressar o limiar de tombamento em termos da aceleração lateral limite de tombamento, paralela à superfície da via, no princípio do tombamento do veículo (PEREIRA NETO, 2007).

$$
a c_{\text {max }}=\frac{t}{2 h} g
$$

em que:

$$
\begin{aligned}
& \mathrm{ac}_{\max }=\text { aceleração lateral limite de tombamento }\left(\mathrm{m} / \mathrm{s}^{2}\right) \\
& \mathrm{t}_{\mathrm{b}}=\text { bitola do veículo }(\mathrm{m}) \\
& \mathrm{h}=\text { altura do centro de gravidade do veículo }(\mathrm{m}) \\
& \mathrm{g}=\text { aceleração da gravidade }\left(\mathrm{m} / \mathrm{s}^{2}\right)
\end{aligned}
$$

A estabilidade lateral dos veículos está limitada então pelo escorregamento lateral para fora da curva e pelo tombamento. O primeiro caso apresenta-se mais restritivo para automóveis, que possuem centro de gravidade baixo e limiares de 
tombamento elevados. Veículos de carga tendem a tombar antes de escorregar, devido a altura do centro de gravidade.

O veículo, independentemente de categoria ou finalidade, deve transmitir ao condutor a sensibilidade necessária para evitar situações de tombamento. Da mesma forma, as unidades rebocadas por apresentarem condições de estabilidade diferentes e por se conectarem umas as outras por articulações, não transmitem ao condutor a mesma sensibilidade que veículos unitários.

Estudos mais elaborados sobre estabilidade de veículos de carga, que consideram o efeito da carga transportada e transmissão de esforços pelas articulações das unidades de veículos combinados, são desenvolvidos no UMTRI - University of Michigan Transportation Research Institute. (Winkler, 2000). 


\subsection{Comportamento do condutor}

O desempenho de um caminhão ou uma CVC depende não só da capacidade mecânica que o veículo tem para percorrer um trecho de rodovia, mas também da capacidade do operador de extrair do veículo o melhor desempenho possível.

O treinamento e a formação de condutores capacitados para correta utilização e melhor aproveitamento dos equipamentos torna-se vital para o sucesso de uma operação, e para a realização em campo de situações de compatibilidade de tráfego previstas em estudos como o proposto neste trabalho.

Jornadas de trabalho compatíveis com as distâncias a serem percorridas é outro fator importante para garantir a segurança das operações. Após longos intervalos de tempo em operação, os condutores têm sua capacidade de operar debilitada pela fadiga, o que pode impedir que extraiam de seus veículos o desempenho esperado.

Neste contexto é esperado que condutores profissionais conheçam e dominem os limites operacionais de seus veículos. Como visto nos capítulos anteriores os veículos possuem limitações variáveis, que dependem da sua geometria, tipo e posição das articulações entre unidades, e das características mecânicas, exigindo que cada operador conheça as particularidades do veículo que opera.

Em suma, os limites operacionais que devem ser conhecidos pelos operadores são:

1) Potência para tracionar a composição, retomar a velocidade, perda de velocidade em aclives, etc

2) Frenagem motora: correta utilização do freio motor e retarders, inclusive quando o acionamento destes é feito manualmente 
3) Frenagem de emergência: evitar a queda de eficiência do sistema de freios auxiliares pela ocorrência de fading, reduzir o travamento prematuro dos pneumáticos (pode ser auxiliado com uso de freios $A B S$ ), evitar situações de instabilidade (jacknife, por exemplo). (Canale, 2007).

4) Sobrelargura: conhecer os movimentos do veículo para otimizar as manobras em interseções e pátios de manobras

5) Estabilidade: evitar acelerações laterais e situações de instabilidade, principalmente próximas aos limites de escorregamento e tombamento (sensibilidade do operador)

Os operadores podem ainda adotar diferentes estratégias de condução, como: reduzir o tempo de viagem, reduzir o consumo de combustível, não ultrapassar a velocidade máxima permitida, manter-se em determinada faixa de rotação, etc. Podem ainda adotar estratégias de condução mistas, como reduzir o consumo de combustível e ao mesmo tempo não ultrapassar a velocidade máxima, estratégias estas que podem ou não ser conflitantes entre si.

Os modelos estudados nos capítulos anteriores não contemplam a variabilidade de desempenho frente à estratégia de condução adotada pelo operador. Consideram que o operador seja sempre capaz de extrair o desempenho máximo do veículo. Tal consideração pode implicar em discrepâncias entre dados coletados em campo de dados gerados em ambiente de simulação, como será evidenciado na seção 3.1 .

Fatores como o tempo entre troca de marchas, a rotação adotada para troca de marchas, a utilização parcial da potência motora disponível para acelerações (limitações da turbina) e o tempo de reação em frenagens de emergência são exemplos de como os operadores podem influir no desempenho do veículo. Vale ressaltar que esses fatores não limitam nem esgotam as possibilidades de divergências entre resultados de simulações e dados coletados em campo, sendo uma área com grande possibilidade para novos estudos. 


\subsection{Consumo de combustível e emissões de poluentes}

Os veículos rodoviários podem ser considerados fontes móveis de emissão de poluentes, pois durante sua operação ocorre a queima do combustível nos cilindros do motor, que fornece energia para movimentar o veículo. Após uma combustão perfeita o combustível (hidrocarboneto) é convertido em gás carbônico ( $\mathrm{CO}_{2}$ e água).

No entanto não se observa a combustão perfeita em veículos automotores, e a combustão imperfeita libera além de $\mathrm{CO}_{2}$ e água, subprodutos como monóxido de carbono $(\mathrm{CO})$, hidrocarbonetos $(\mathrm{HC})$, óxidos de nitrogênio $\left(\mathrm{NO}_{\mathrm{x}}\right)$ e material particulado. Os veículos aumentam a poluição atmosférica não só pela queima imperfeita, mas também pela evaporação de combustível, que ocorrem durante a operação do veículo, após seu desligamento, diariamente no tanque de combustível e no reabastecimento (Jacondino, 2005). Esses subprodutos da combustão imperfeita do combustível são nocivos ao meio ambiente, como mostra a Tabela 4.

\section{Tabela 4: Poluentes e suas implicações}

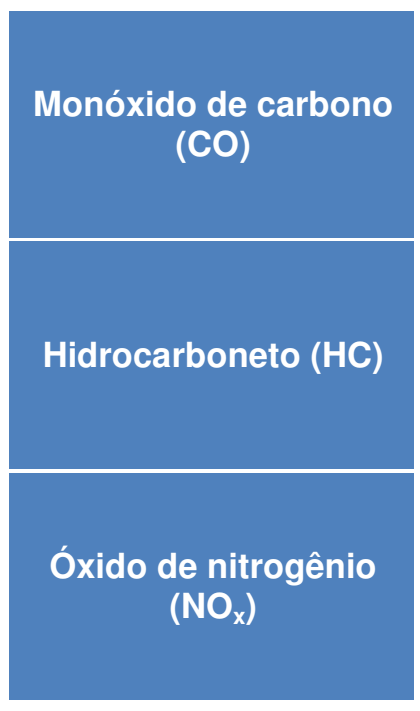

Produto da combustão incompleta do combustível, é um gás incolor, inodoro e tóxico, que reduz o fluxo de oxigênio no sangue e é prejudicial a todos os organismos vivos.

Produto da combustão incompleta do combustível, que se exposto a radiação solar reage com óxidos de nitrogênio e contribui para a formação da camada de ozônio. Causa irritação nos olhos e nas pregas vocais, além de afetar o bom funcionamento do sistema respiratório. É uma substância tóxica e pode causar câncer.

Formado durante a combustão pela reação do nitrogênio com o oxigênio sob alta pressão e temperatura. Contribui para a formação da camada de ozônio e ocorrência de chuva ácida.

Outro fator importante a considerar é a relação da mistura ar/combustível, que afeta o funcionamento dos catalisadores. Misturas pobres em combustível favorecem a formação $\mathrm{NO}_{x}$, comum em rodovias congestionadas, enquanto mis- 
turas ricas em combustível favorecem a formação de $\mathrm{CO}$ e HC (comum em partidas a frio, acelerações rápidas até altas velocidades e trechos de aclive).

Exposto os riscos e danos ao meio ambiente que os poluentes emitidos pelos veículos causam, toma importância o estudo de modelos que permitam prever tanto o consumo de combustível como a emissão de poluentes. O tema foi objeto de estudo de muitas pesquisas, e uma série de modelos matemáticos foi desenvolvida nesse intuito.

O domínio desta tecnologia viabiliza o estudo de rodovias sustentáveis, que consideram em projeto a emissão de poluentes nos trechos, assim como medidas para reduzir a emissão total, maximizando o benefício social do projeto e diminuindo assim seu custo global. Outra possibilidade é a quantificação de benefícios derivados de solução ITS (Intelligent Transportation System). Por parte dos operadores, a modelagem do fenômeno permite estimar o custo com combustível em determinada operação, assim como os pontos de maior e menor consumo.

Os modelos encontrados na literatura podem ser classificados em dois tipos, macroscópicos e microscópicos. O primeiro tipo apresenta equações simplificadas que estimam o consumo de combustível e a taxa de emissão de poluentes de uma via a partir da velocidade média do veículo, sem considerar as variações de velocidade e acelerações. O segundo tipo determina o consumo de combustível e a taxa de emissão de poluentes em função da potência motora utilizada e da rotação do motor, permitindo assim caracterizar diferenças devido à características mecânicas dos veículos.

Modelos macroscópicos:

Calculam taxas de emissão com base: no tipo de veículo, na corrente de tráfego, na idade do veículo, velocidade média, temperatura, altitude, carga transportada, uso de ar condicionado, e modo de operação do veículo. Esta taxa de emissão é multiplicada pela distância viajada e pelo número de veículos, e então se determina a quantidade de poluentes emitidos. São exemplos de modelos macroscó- 
picos o MOBILE6 (EPA, 2007), que fornece a emissão de $\mathrm{HC}, \mathrm{CO}$ e $\mathrm{NO}_{\mathrm{x}}$, e o modelo EMFAC desenvolvido pela CARB - California Air Resources Board (Ahn, 1998), que fornece também a quantidade de material particulado.

Modelos microscópicos:

Consumo de combustível e emissão de poluentes são calculados com base em taxas de consumo e emissão relacionadas com a potência veicular, força tratora, aceleração, velocidade, etc. Os cálculos são revistos a cada incremento de tempo, observando a modificação das condições da via e do tráfego. Os modelos microscópicos assumem o princípio da conservação de energia, assim, toda a energia gerada para a movimentação do veículo provém da queima do combustível.

Este trabalho irá utilizar um modelo microscópico para calcular o consumo de combustível do veículo em operação, considerando as características mecânicas e de operação dos veículos, como: potência e rotação instantâneas, velocidade e aceleração. Os principais fatores que afetam o consumo de combustível e a emissão de poluentes estão associados e podem ser classificados em quatro grupos (AHN, 1998):

1) Viagem: quantidade de viagens, distância viajada, porcentagem de caminhões, etc.

2) Condutor: estratégia de condução

3) Via: inclinações longitudinais, superfície do pavimento

4) Veículo: eficiência mecânica, estado de conservação, equipamentos acoplados, etc.

A Tabela 5 apresenta exemplos de fatores que afetam o consumo de combustível e a taxa de emissão de poluentes. 


\begin{tabular}{|c|c|}
\hline Fator & Efeito \\
\hline Aceleração & $\begin{array}{l}\text { Taxas elevadas de aceleração representam aumento na potência utilizada } \\
\text { pelo motor, e assim na energia necessária para produzir esta potência, ou } \\
\text { seja, aumento no consumo de combustível. }\end{array}$ \\
\hline Acessórios & $\begin{array}{l}\text { Acessórios como ar condicionado, transmissão automática, direção hidráu- } \\
\text { lica, bancos com regulagem eletrônica, vidros elétricos e outros sistemas } \\
\text { movidos direta ou indiretamente pela energia gerada no motor fazem com } \\
\text { que parte da energia produzida com a queima de combustível não seja } \\
\text { convertida em deslocamento. }\end{array}$ \\
\hline Aclives & $\begin{array}{l}\text { Aumentam a resistência de rampa e assim a energia necessária para per- } \\
\text { correr uma mesma distância. }\end{array}$ \\
\hline $\begin{array}{l}\text { Atrito interno } \\
\text { (motor e trans- } \\
\text { missão) }\end{array}$ & $\begin{array}{l}\text { Transmissões ineficientes fazem com que parte do consumo de combustí- } \\
\text { vel não seja convertida em torque nos eixos tratores. Similarmente ocorre } \\
\text { com veículos que não tem manutenção regular. }\end{array}$ \\
\hline $\begin{array}{l}\text { Carga transporta- } \\
\qquad \text { da }\end{array}$ & $\begin{array}{l}\text { Transportar mais carga significa necessitar de mais energia para percorrer } \\
\text { a mesma distância, o que aumenta o consumo de combustível. }\end{array}$ \\
\hline $\begin{array}{l}\text { Condições climá- } \\
\text { ticas }\end{array}$ & $\begin{array}{l}\text { Baixas temperaturas (combustão ineficiente), ventos fortes (aumento da } \\
\text { resistência aerodinâmica), altas temperaturas (aumento da evaporação) }\end{array}$ \\
\hline $\begin{array}{l}\text { Estratégia de } \\
\text { condução }\end{array}$ & Acelerações bruscas tendem aumentar o consumo de combustível. \\
\hline $\begin{array}{l}\text { Evaporação de } \\
\text { combustível }\end{array}$ & $\begin{array}{l}\text { Durante uma viagem ou mesmo quando o veículo está parado ocorre eva- } \\
\text { poração do combustível antes que esse chegue ao motor para combustão. } \\
\text { Esta evaporação varia com a temperatura e as condições de manutenção } \\
\text { do veículo. Motor afogado. }\end{array}$ \\
\hline Geometria da via & $\begin{array}{l}\text { Interseções e obstáculos que aumentem as necessidades de variação da } \\
\text { velocidade contribuem para o aumento da emissão, similarmente os aclives } \\
\text { também contribuem para emissão, pois exigem maior energia para manter } \\
\text { a mesma velocidade }\end{array}$ \\
\hline Partidas a frio & $\begin{array}{l}\text { A combustão incompleta do combustível ocorre quando o motor opera em } \\
\text { temperaturas abaixo da qual foi dimensionado, desta forma, parte do con- } \\
\text { sumo não é convertida em energia para deslocar o veículo. As partidas a } \\
\text { frio dependem do tempo que o veículo ficou desligado antes da viagem e } \\
\text { de quanto tempo o veículo viajou. Motores consomem mais no início da } \\
\text { operação, até atingir a temperatura ideal de funcionamento. Motor afogado. }\end{array}$ \\
\hline Pneus & $\begin{array}{l}\text { Quando mal calibrados, aumentam a resistência ao rolamento, uma vez } \\
\text { que aumentam a superfície de contato pneu-pavimento e assim o consumo } \\
\text { de combustível. }\end{array}$ \\
\hline $\begin{array}{l}\text { Superfície irregu- } \\
\text { lar }\end{array}$ & $\begin{array}{l}\text { Aumenta a resistência ao rolamento e conseqüentemente o consumo de } \\
\text { combustível. }\end{array}$ \\
\hline
\end{tabular}




\begin{tabular}{|l|l|}
\hline Fator & \multicolumn{1}{c}{ Efeito } \\
\hline Tráfego & $\begin{array}{l}\text { A interação entre veículos faz com que frenagens e retomadas de veloci- } \\
\text { dade não necessárias numa situação de fluxo livre ocorram, ou seja, mais } \\
\text { acelerações e aumento no consumo. }\end{array}$ \\
\hline Veículo & Motores com cilindros maiores tendem a consumir mais combustível. \\
\hline Velocidade & $\begin{array}{l}\text { O de rolamento da velocidade provoca aumento nas resistências aerodinâmica } \\
\text { correr o mesmo trecho. Velocidades muito baixas, como ocorre em situa- } \\
\text { ções de fluxo congestionado também ocorre aumento do consumo, uma } \\
\text { vez que o veículo gasta energia apenas para manter o motor em funcio- } \\
\text { namento. }\end{array}$
\end{tabular}

Para minimizar os impactos indesejáveis da emissão de poluentes, algumas medidas são sugeridas pela literatura.

1) Criação de órgãos fiscalizadores como o Environmental Protection Agency EPA, criado nos EUA em 1970 pelo CAAA - Clean Air Act Amendments.

2) Definição de níveis máximos de emissão por poluente e por via ou rodovia

3) Incentivos ao desenvolvimento de tecnologias veiculares menos poluentes ou que reduzam a poluição, como catalisadores.

4) Incentivos ao desenvolvimento de combustíveis "limpos".

5) Soluções de gerenciamento de tráfego e regulamentações próprias para o setor, restrições ao tráfego de veículos com baixo fator de ocupação (carga ou passageiro).

6) Restrições de tráfego para veículos poluidores em vias: classificação de vias, metas para controle da emissão, sansões e multas, valorização de veículos não poluentes.

7) Análise de impacto ambiental em projetos de rodovias.

8) Incentivos fiscais para empresas que apresentem soluções para a redução do consumo e emissão (carona, vale transporte, bicicleta, etc).

9) Cobrança de sobretaxa em rodovias e parques de estacionamento.

10) Redução no número de viagens e conseqüentemente no consumo e emissão, com o aumento da capacidade de veículos. 
Assim, a emissão de poluentes está associada ao consumo de combustível e à eficiência da combustão deste. As seções 2.7.1 a 2.7.5 apresentam modelos microscópicos desenvolvidos para quantificar o consumo de combustível.

\subsection{1. "Modelo de Post"}

O modelo calcula o consumo de combustível como função da potência instantânea desenvolvida pelo veículo. Para construção do modelo o autor coletou dados de um dinamômetro acoplado ao chassi de um veículo-teste, que registrava a força instantânea produzida. Com os registros de força instantânea calculou a potência desenvolvida pelo motor (Post et al, 1984).

$$
\begin{aligned}
& F=\alpha+\beta . P \\
& F=\alpha
\end{aligned}
$$

em que:

$\mathrm{F}=$ consumo instantâneo $(\mathrm{ml} / \mathrm{s})$

$\alpha$ = consumo inerente ao movimento, dependente da estabilidade do motor em marcha lenta e da taxa de mistura ar/combustível $(\mathrm{ml} / \mathrm{s})$ $\beta=$ parâmetro dependente dos tempos de ignição, bloqueios na entrada de ar, e outros parâmetros ( $\mathrm{ml} / \mathrm{s} . \mathrm{kW})$ $\mathrm{P}=$ potência fornecida pelo motor $(\mathrm{kW})$

\subsection{2. "Modelo ARRB"}

O modelo da ARRB - Australian Road Research Board, desenvolvido por Akcelic (1989), difere do Modelo de Post pelo tratamento dado ao parâmetro $\beta$. Segundo Akcelic a adoção de um valor constante para esse parâmetro não gera resultados acurados, uma vez que o mesmo varia com velocidade e aceleração instantâneas. Sugere como solução a adoção de dois parâmetros de eficiência, $\beta_{1}$ e 
$\beta_{2}$, e uma potência referente à inércia do próprio veículo, conforme equações abaixo apresentadas.

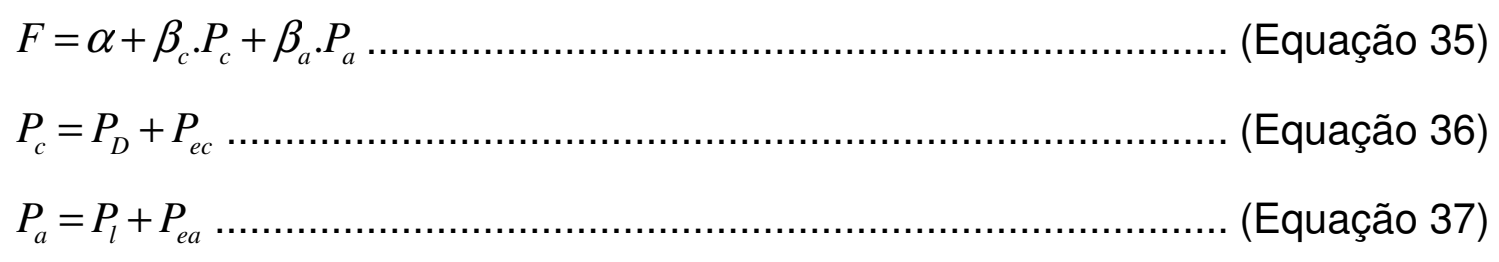

em que:

$\mathrm{F}=$ consumo instantâneo $(\mathrm{ml} / \mathrm{s})$

$\alpha=$ consumo inerente ao movimento $(\mathrm{ml} / \mathrm{s})$

$\beta_{\mathrm{c}}$ e $\beta_{\mathrm{a}}=$ parâmetros veiculares (ml/s.kW)

$P_{c}=$ potência total durante viagem com velocidade constante $(\mathrm{kW})$

$\mathrm{P}_{\mathrm{a}}=$ potência relativa à inércia do veículo $(\mathrm{kW})$

$P_{D}, P_{I}=$ potências associadas à inércia $(k W)$

$\mathrm{P}_{\mathrm{ec}}, \mathrm{P}_{\mathrm{ea}}=$ potências associadas às resistências internas durante movimento uniforme e acelerado (kW)

Ahn (1998) apresenta uma ressalva quanto a aplicação dos modelos de Post e da ARRB durante desacelerações. A explicação deve-se ao fato de que durante a frenagem esses modelos consideram o consumo e a emissão quando a força no chassi é nula (taxa $\alpha$ ). Em linhas gerais o consumo de combustível é mais alto quando em velocidades altas, inclusive em desacelerações, o que foi verificado em sua pesquisa com dados do ORNL - Oak Ridge National Lab.

\subsection{3. "CMEM"}

O modelo CMEM - Comprehensive Modal Emissions Model (Barth et al., 2000), estima as emissões de poluentes de veículos leves e pesados (LDV - Light-duty Vehicle e LDT - Light-duty Trucks), como função do modo de operação desses veículos, especialmente no que se refere ao estado de funcionamento dos veículos. É um modelo parametrizado que busca representar todo o processo de e- 
missão associado à operação do veículo. Adota como parâmetros de entrada: velocidade, aceleração, inclinação da pista, coeficiente de partida a frio, e atrito nas partes internas do veículo. Os veículos são categorizados segundo sua contribuição na emissão de poluentes. As variáveis para definir a categoria do veículo incluem: controle tecnológico de combustível e emissão (catalisador, injeção eletrônica), quilometragem acumulada, relação potência/massa, certificado do nível de emissão e categoria da emissão (alta, baixa).

2.7.4. "VT-Micro" - Virginia Tech Microscopic energy and emissions model

Modelo de regressão híbrido que considera a velocidade e a aceleração instantâneas como parâmetros de entrada, estima o consumo de combustível e a taxa de emissão de poluentes de veículos leves e pesados, operando com temperatura estável.

$$
\begin{gathered}
M O E_{e}=e^{\sum_{i=0}^{3} \sum_{j=0}^{3}\left(L_{i, j}^{e} \cdot V^{i} \cdot a^{j}\right)}, \text { para } \mathrm{a} \geq 0 \\
M O E_{e}=e^{\sum_{i=0}^{3} \sum_{j=0}^{3}\left(M_{i, j}^{e} \cdot V^{i} \cdot a^{j}\right)}, \text { para } \mathrm{a}<0
\end{gathered}
$$

em que:

$$
\begin{aligned}
& \mathrm{MOE}_{\mathrm{e}}=\text { emissão instantânea }(\mathrm{mg} / \mathrm{s}) \\
& L_{i, j} e_{i, j} M_{i, j}=\text { coeficiente para velocidade "i " e aceleração " } j \text { " } \\
& \mathrm{V}=\text { velocidade do veículo }(\mathrm{km} / \mathrm{h}) \\
& \mathrm{a}=\text { aceleração }\left(\mathrm{m} / \mathrm{s}^{2}\right)
\end{aligned}
$$

O modelo foi validado por Ahn (1998), com dados do ORNK - Oak Ridge Nacional Laboratory, que implementou em seu trabalho esse modelo no software INTEGRATION. Os gráficos da Figura 22 apresentam a comparação dos dados coletados na pesquisa de Ahn com o modelo VT-Micro. 

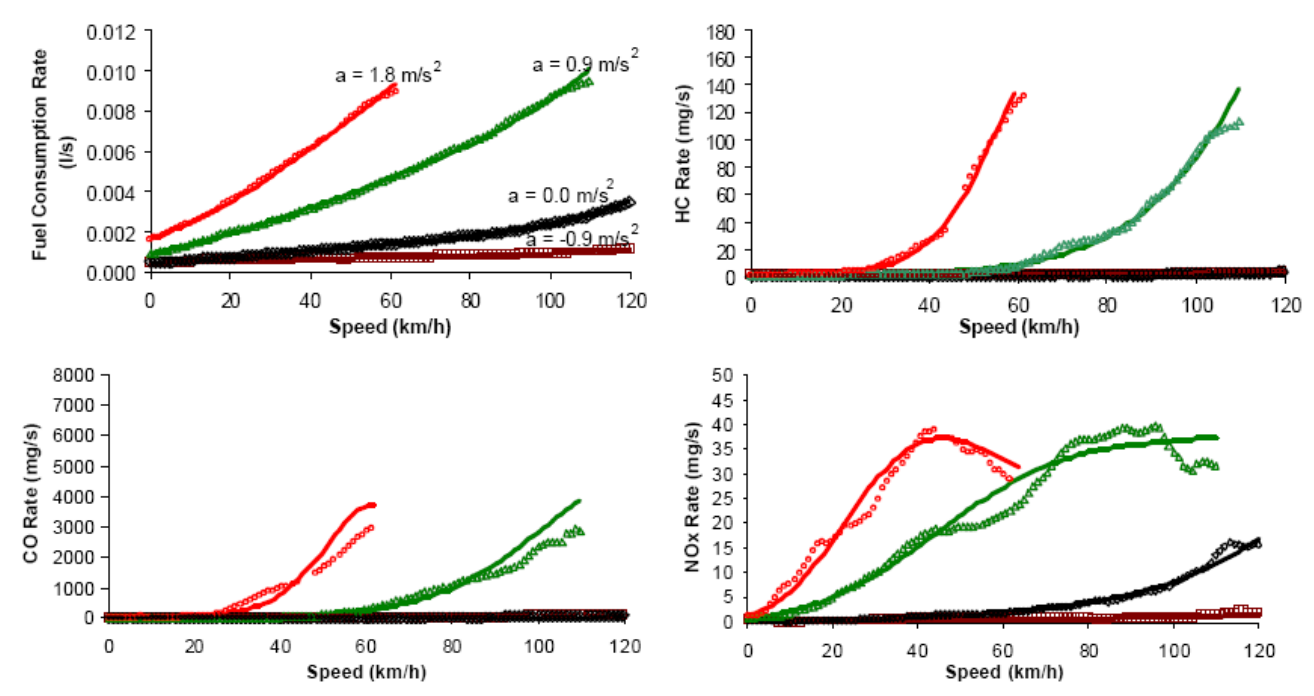

Figura 22: Taxa de emissão de poluentes e consumo de combustível (Ahn, 1998)

A Figura 22 mostra que também é possível estabelecer modelos correlacionando velocidade, aceleração e tipo de poluente emitido $\left(\mathrm{HC}, \mathrm{CO}, \mathrm{NO}_{\mathrm{x}}\right)$, bastando para isso calibrar os coeficientes das Equações 39 e 40.

Segundo Bartholomeu (2006), dadas as características médias do diesel fornecido no Brasil, é possível adotar a taxa de emissão média de 2,75 kg de gás carbônico $\left(\mathrm{CO}_{2}\right)$ por litro de combustível consumido.

\subsection{5. "Curva de Consumo específico"}

É possível, ao longo de um trecho, desde que sejam conhecidos a curva de consumo específico do motor do veículo, a rotação instantânea ( $\mathrm{rpm})$, a potência instantânea $(\mathrm{kW})$, e o intervalo incremental de tempo, calcular o consumo instantâneo de combustível. A curva de consumo específico é fornecida pelos fabricantes de motores, como ilustrada a Figura 23. Similarmente ao modelo de tração, os fabricantes fornecem a curva de consumo para utilização da potência máxima do motor. 


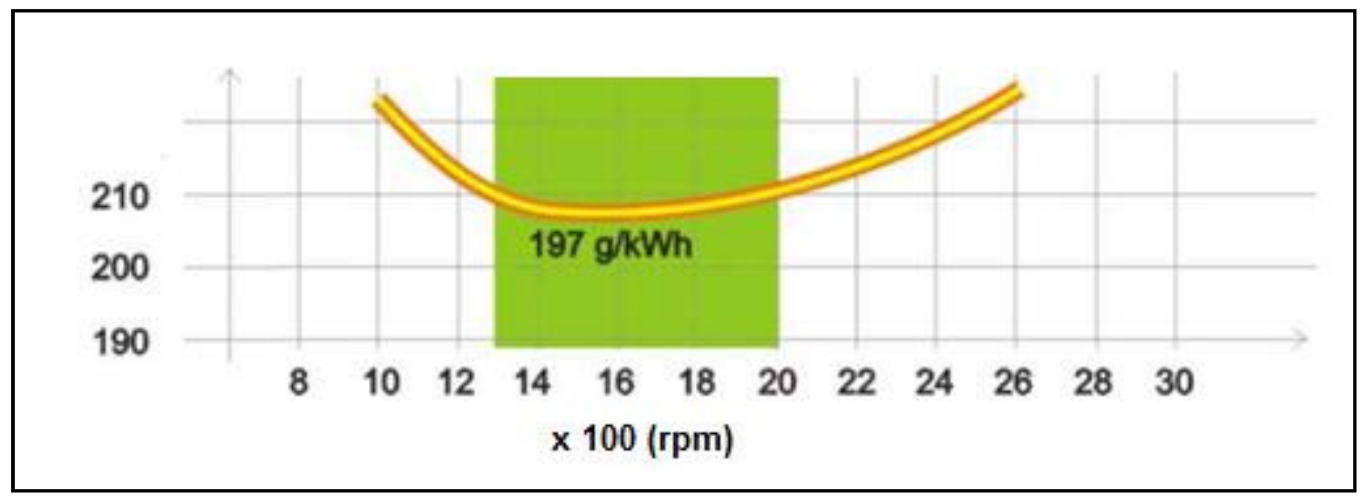

Figura 23: Curva de consumo específico (g / kW.h)

A Equação 40 permite o cálculo do consumo instantâneo a partir da curva de consumo específico.

Consumo $_{\text {Ins tan taneo }}=P \times$ Consumo $_{e}$ .(Equação 40)

em que:

Consumo $_{\text {Instantâneo }}=$ taxa de consumo instantânea $(\mathrm{g} / \mathrm{h})$

$\mathrm{P}=$ potência fornecida pelo motor $(\mathrm{kW})$

Consumo $_{\text {especifico }}=$ consumo específico do motor do veículo $(\mathrm{g} / \mathrm{kW} . \mathrm{h})$

A taxa de consumo instantâneo, aplicada durante um intervalo incremental de tempo, fornece o consumo instantâneo, que pode ainda ser convertido em litros, desde que conhecida a densidade do combustível. A Equação 41 apresenta o cálculo do consumo instantâneo em litros.

Consumo $=\frac{\text { Consumo }_{\text {ins tan tâneo }} \times \Delta t}{\rho}$ .(Equação 41)

em que:

Consumo $=$ consumo durante $\mathrm{o}$ incremento de tempo (I)

Consumo $_{\text {Instantâneo }}=$ taxa de consumo instantânea $(g / h)$

$\Delta t=$ incremento de tempo $(h)$

$\rho=$ densidade do combustível $(0,74 \mathrm{~g} / \mathrm{l}$ a $0,82 \mathrm{~g} / \mathrm{l})$ 
Alterações na composição do combustível alteram a curva de consumo específico. Para uma rotação e potência determinada, o mesmo motor pode apresentar taxas de consumo de combustível diferentes para misturas de combustíveis distintas.

O conceito de cálculo de consumo de combustível pela curva de consumo específico pode ser estendido para o cálculo do consumo com utilização do mapa de consumo específico do motor, em que o consumo varia não só com a rotação, mas com a potência que o motor desenvolve em cada rotação. Outra forma de exibir o mapa de consumo específico do motor é em um gráfico tridimensional, em função da aceleração e da velocidade, como o mostrado na Figura 24.

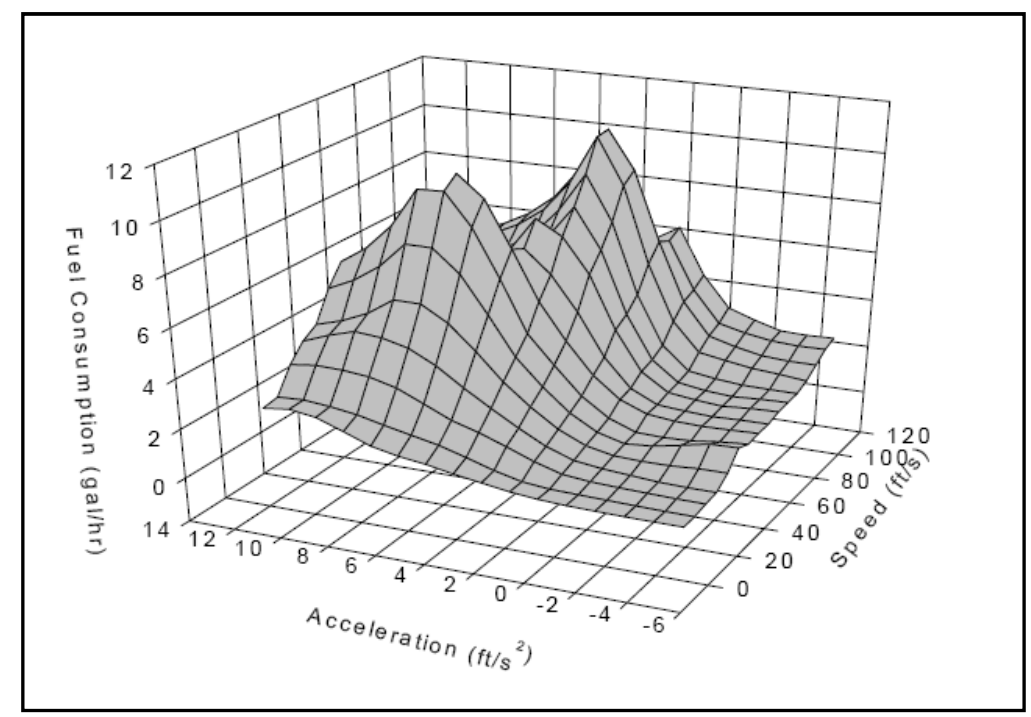

Figura 24: Mapa de consumo específico de um motor (Ahn, 1998) 


\section{MÉTODO}

A revisão bibliográfica apresentada no Capítulo 2 mostra a abrangência e dispersão das frentes de pesquisa sobre caminhões pesados, deixando aberto campo para este trabalho, que visa agregar estudos e criar ferramentas que auxiliem operadores do transporte rodoviário de carga a certificar operações e otimizar a utilização de sua frota.

Para agregar estes estudos e criar ferramentas que permitam a manipulação dos dados e geração de resultados com acurácia satisfatória para operadores e órgãos fiscalizadores de rodovias, definiu-se como método a construção de um simulador para prever o desempenho de caminhões e CVCs em rodovias. $O$ simulador, deste ponto em diante denominado SimVC, é formado por modelos estudados no Capítulo 2, sendo que os resultados gerados nas simulações permitem a comparação de desempenho entre tecnologias rodoviárias de transporte.

Construído o simulador, verificou-se a consistência dos dados por ele gerados comparando com dados obtidos de curvas de aceleração propostas no manual da AASHTO e perfis de velocidade em função da distância percorrida e perfil geométrico da rodovia, coletados e modelados em outras pesquisas desenvolvidas no Brasil.

A seção 3.1, Construção do Simulador, apresenta a forma como foram estruturados os bancos de dados para configuração de cenários de simulação e o desenvolvimento dos algoritmos utilizados no SimVC.

A seção 3.2 mostra as verificações de consistência realizadas e demonstra possíveis divergências encontradas. 


\subsection{Construção do simulador SimVC}

Como visto no Capítulo 2, veículos pesados possuem diferentes restrições ao tráfego. Para estruturar o simulador, as restrições foram divididas em estáticas e dinâmicas, descritas a seguir:

1) Restrições estáticas são aquelas que não dependem da capacidade motora do veículo. São exemplos de restrições estáticas: gabaritos horizontal e vertical das vias, gabaritos de conversões, limiares de tombamento e escorregamento, distância de visibilidade e parada, etc.

2) Restrições dinâmicas são aquelas que dependem da potência motora acoplada à unidade tratora, como: velocidades mínima ou máxima ao longo de um trecho, consumo de combustível, emissão de poluentes, aclive e declive máximos que o veículo é capaz de vencer, etc.

Desta forma, é possível analisar a compatibilidade de tráfego de duas maneiras independentes. Nas análises estáticas, predomina o conhecimento e estudo das dimensões e articulações dos veículos, enquanto que na análise dinâmica é necessário o conhecimento da capacidade motora da composição. A condição de carregamento influi em ambos os casos, pois altera o centro de gravidade da composição, interferindo nos limiares de tombamento e escorregamento, na estabilidade da composição, e na massa a ser acelerada pelo motor acoplado.

As características de veículos e vias podem ser entendidas como os parâmetros ou condições de contorno necessárias para caracterizar uma operação de carga em uma simulação. A definição de cada um desses parâmetros resulta em um cenário de simulação, que possibilita executar os algoritmos e dos resultados obtidos identificar restrições estáticas e/ou dinâmicas existentes.

O estudo dos modelos permite relacioná-los aos tipos de restrições, como mostra a Figura 25. 


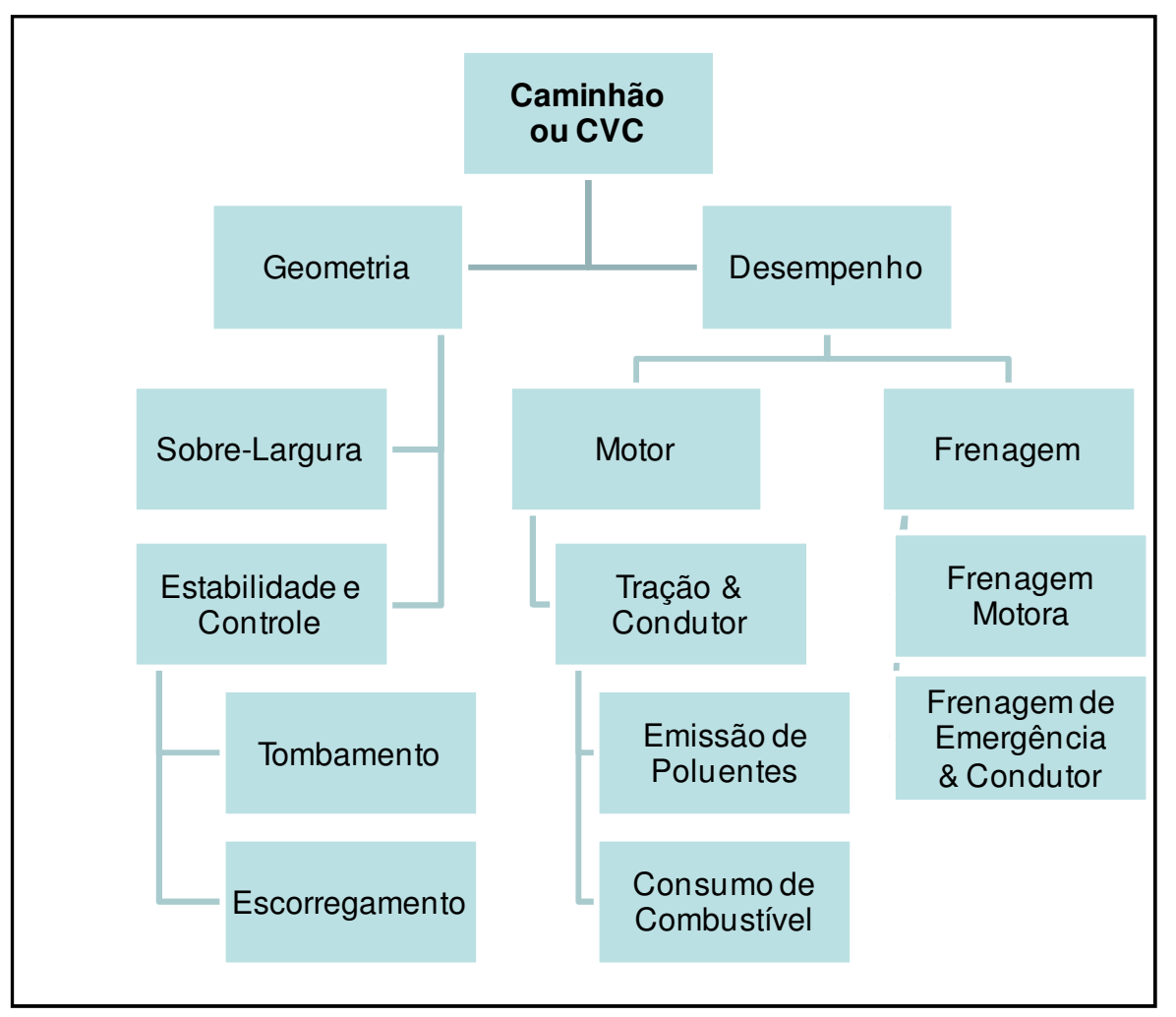

Figura 25: Relações de dependência entre modelos

Os modelos para cálculo de sobrelargura, tombamento, escorregamento são amplamente aceitos e utilizados na elaboração de projetos de rodovias e interseções. Já os modelos de desempenho não são utilizados em projetos e apesar de sua modelagem matemática ser relativamente simples seu uso não possui larga abrangência. Com a diversificação do uso dos computadores nas últimas décadas tornou-se possível a divulgação e aplicação em projeto de modelos desenvolvidos e validados em pesquisas recentes, agregando qualidade técnica ao trabalho dos operadores de transporte.

Assim, foram selecionados os modelos mais utilizados e aceitos pela comunidade científica, sendo implementados na forma de um algoritmo, segundo as áreas de aplicação abaixo:

1) Tração: modelo de micro-simulação validado por Melo (2002), conforme estrutura apresentada na Figura 8, complementado pelo autor com variáveis que podem, sob controle do usuário, intervir ou não na simulação, como: tempo entre troca de marchas, rotação para a troca de marcha, velocidade máxima de operação. Considera o motor operando a plena carga. 
2) Frenagem motora: modelo proposto por Lucas (2004), que considera o equilíbrio entre as potências adquiridas ao percorrer um declive longo e dissipadas pelo motor do veículo com ou sem o auxílio de retardador. Calcula também a elevação da temperatura dos freios auxiliares quando utilizados de forma constante.

3) Frenagem de emergência: cálculo da distância de visibilidade e parada pelo modelo proposto pela AASHTO (2004) e adotado pelo DNIT (DNER, 1999). Não é um modelo validado, mas um critério de projeto admitido como satisfatório, que o veículo deve atender, mediante teste de campo.

4) Sobrelargura: simulação de conversões por curva tractrix com o auxílio do software AutoTurn (2003). A implementação desse modelo não foi possível em ambiente Excel, contudo o banco de dados permite o armazenamento das dimensões dos veículos e posterior utilização do software.

5) Estabilidade e controle: cálculo dos limiares de tombamento e escorregamento segundo a metodologia da AASHTO (2004), ou seja, a determinação das acelerações limites que um veículo pode submeter-se quando definido o carregamento (altura do centro de gravidade) e a distância entre eixos do veículo (bitola). O cálculo da estabilidade para toda a composição, considerando a transferência de esforços entre elas, exige modelos mais elaborados, como os propostos por Winkler (2000), cuja complexidade ultrapassa o escopo deste trabalho.

6) Comportamento do condutor: foi adicionado um fator de utilização da potência motora disponível, o que significa que o operador não busca a aceleração máxima disponível, mas uma parcela desta aceleração, assumindo assim que a potência varia linearmente de zero à potência máxima, de acordo com o fator de utilização da potência adotado.

7) Consumo de combustível: calculado através da curva de consumo específico à plena carga do motor, em função da rotação, fornecida pelo fabricante do 
motor. Desta forma o cálculo fica associado aos modelos de tração e do condutor, que fornecem a potência utilizada.

8) Emissão de poluentes: cálculo da taxa de emissão média de $\mathrm{CO}_{2}$ em função do consumo instantâneo de combustível, e conseqüentemente em função dos resultados gerados pelos modelos de tração e do condutor.

Os modelos acima citados permitiram criar uma lista de variáveis de entrada e saída dos modelos e relacioná-los em uma seqüência lógica de execução. Relacionadas as variáveis, o simulador foi desenvolvido em três etapas: banco de dados, algoritmo e interface.

A primeira caracterizada pela estruturação de um banco de dados para armazenamento das características de veículos e trechos de rodovias (parâmetros de entrada). Os dados foram armazenados em seis pastas, a saber: CVC, Caminhão, Motor, Caixa de Mudanças, Diferencial e Rodovia. O Anexo C, Manual do usuário, apresenta a relação dos dados armazenados em cada banco de dados, a lista dos parâmetros ajustáveis para configurar um cenário de simulação, ilustrações da interface e detalhes de sua utilização.

A segunda etapa consistiu em desenvolver uma interface para configuração de cenários de simulação, em que é possível definir outras condições de contorno necessárias para a execução das macros, como coeficientes de atrito e PBTC. Esta forma de armazenar dados e rotinas de cálculo permite que futuros trabalhos agreguem outros modelos para estudos semelhantes, aproveitando a estrutura aqui desenvolvida.

Por fim, foram construídos os algoritmos de SimVC, implementando-se os modelos em rotinas de cálculo (macros), que lêem as configurações determinadas pelo usuário no cenário de simulação, buscam os dados necessários nos bancos de dados desenvolvidos na primeira etapa, executam os cálculos pertinentes e imprimem os resultados em uma pasta de trabalho do Excel. O Anexo $\mathrm{B}$, Algoritmos das macros, apresenta as rotinas de cálculos implementadas. 


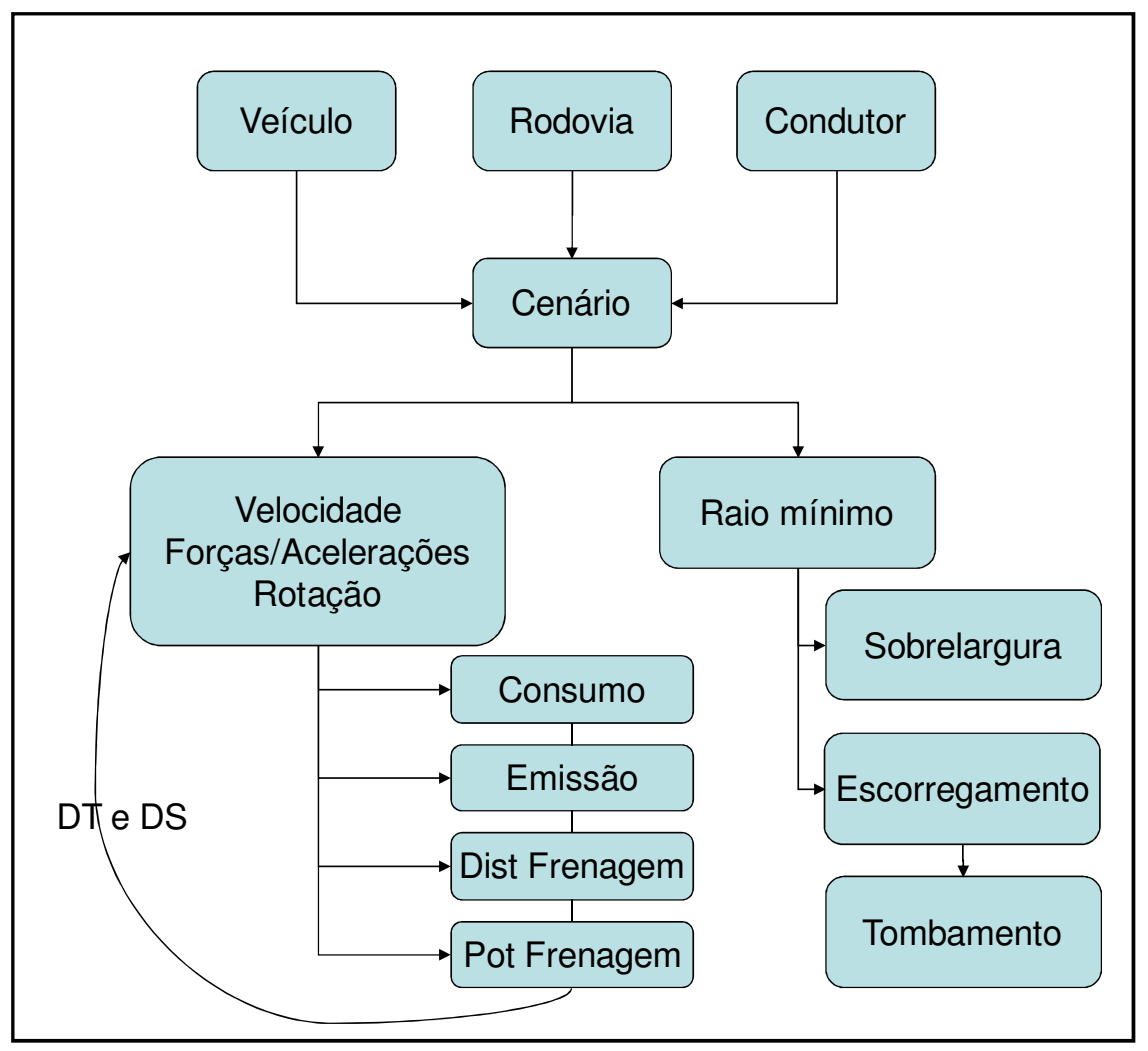

Figura 26: Fluxograma do funcionamento de SimVC

A Figura 26 apresenta o fluxograma para execução de uma simulação. Inicialmente são definidos todos os parâmetros de entrada, configurando assim um cenário. Em seguida opta-se por simular o desempenho de um caminhão ou CVC em um trecho de rodovia ou calcular seus limites operacionais em trechos com restrições geométricas.

Na seção 3.2 são verificados os algoritmos de desempenho. Os resultados gerados para os limites operacionais como sobrelargura, limiares de tombamento e escorregamento não foram verificados, pois constituem na aplicação direta de equações amplamente difundidas na literatura técnica.

Na seção 3.3 discute-se a consistência dos resultados da verificação e fatores pouco abordados na literatura técnica, como particularidades do algoritmo de simulação e a influência do condutor. 


\subsection{Verificação do algoritmo}

O algoritmo de tração implementados na planilha SimVC já foram utilizados e calibrados em outras pesquisas. Archilla (1996) calibrou o modelo para relações massa/potência típicas da Rodovia Nacional 7 da Argentina. Melo (2002) calibrou e validou o modelo através da comparação dos valores teóricos de velocidade gerados pelo modelo e velocidades reais medidas em aclives, utilizando o procedimento de Willey (1949) para validação; como resultado sugere a utilização dos parâmetros de calibração segundo a categoria do veículo, como mostra a Tabela 6.

Tabela 6: Parâmetros usados no modelo de desempenho (Melo, 2002)

\begin{tabular}{|c|c|c|c|c|}
\hline Parâmetro & $\begin{array}{l}\text { Rígido leve } \\
(100 \mathrm{~kg} / \mathrm{kW})\end{array}$ & $\begin{array}{l}\text { Rígido pesado } \\
(200 \mathrm{~kg} / \mathrm{kW})\end{array}$ & $\begin{array}{c}\text { Articulado leve } \\
(140 \mathrm{~kg} / \mathrm{kW})\end{array}$ & $\begin{array}{c}\text { Articulado pesado } \\
(180 \mathrm{~kg} / \mathrm{kW})\end{array}$ \\
\hline m (kg) & 10.469 & 21.850 & 27.831 & 42.120 \\
\hline $\mathrm{m}_{\mathrm{ta}}(\mathrm{kg})$ & 6.965 & 8.565 & 9.271 & 10.370 \\
\hline$\mu$ & 0,6 & 0,6 & 0,6 & 0,6 \\
\hline$P(k W)$ & 103,3 & 111,2 & 196,7 & 242,7 \\
\hline$\eta$ & 0,87 & 0,87 & 0,87 & 0,87 \\
\hline$C_{d}$ & 0,8 & 0,7 & 0,9 & 0,8 \\
\hline $\mathrm{C}_{\mathrm{h}}$ & 1,0 & 1,0 & 1,0 & 1,0 \\
\hline$A\left(m^{2}\right)$ & 7,7 & 6,5 & 9,0 & 7,5 \\
\hline$\overline{C_{r}}$ & 1,2 & 1,2 & 1,2 & 1,2 \\
\hline $\mathrm{C}_{2}$ & 0,0125 & 0,0125 & 0,0125 & 0,0125 \\
\hline$\overline{C_{3}}$ & 7,6 & 7,6 & 7,6 & 7,6 \\
\hline$L(m)$ & 7,0 & 9,0 & 17,0 & 17,0 \\
\hline
\end{tabular}


Lucic (2001) calibrou o mesmo modelo para um caminhão teste, tipo 12S3, com 10 combinações de carregamento. Nessa calibração, o veículo parte do repouso e acelera livremente em um trecho de geometria conhecida.

Cunha (2007) coletou perfis de velocidade de caminhões e CVCs em um trecho da rodovia SP-310. Com o auxilio de um algoritmo genético, calibrou o software CORSIM, que utiliza curvas de aceleração similares às de tração e resistência ao movimento para simular o desempenho desses veículos. A Figura 27 ilustra as aproximações obtidas, utilizando o parâmetro EMA (Erro Médio Absoluto) na calibração.

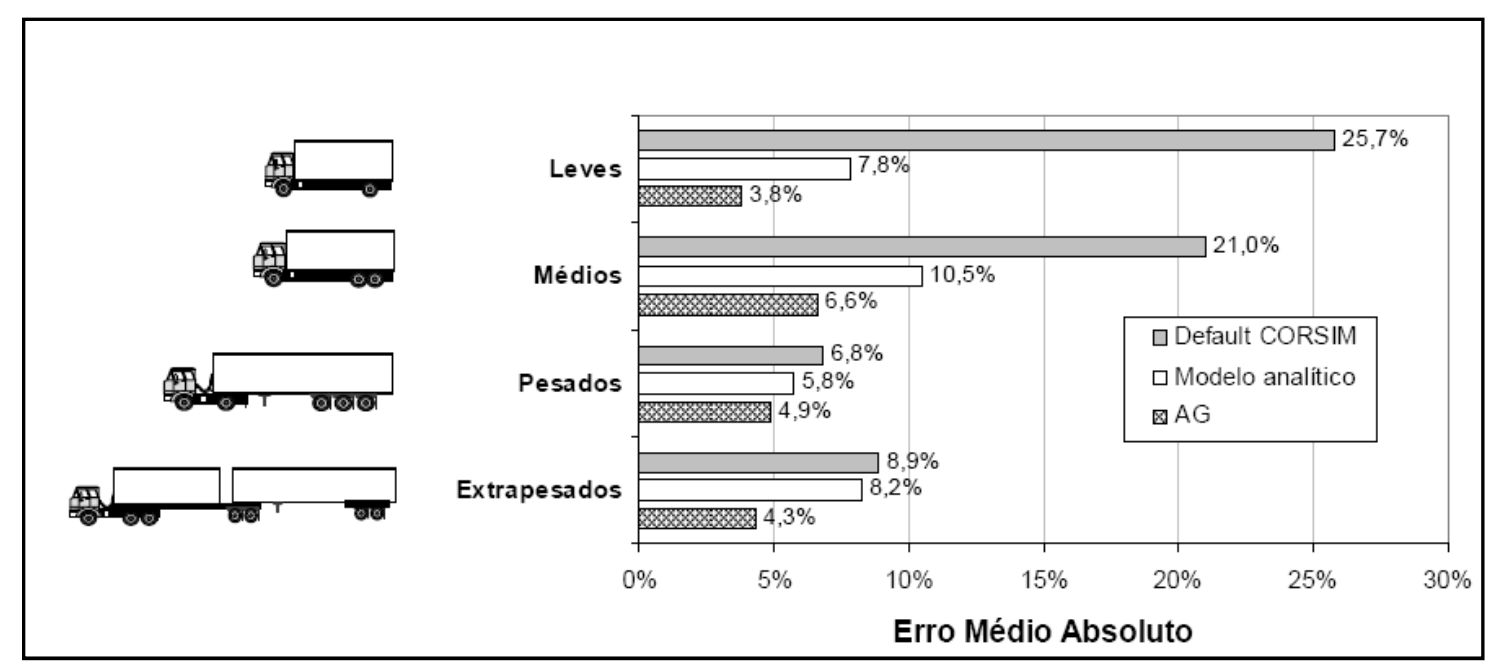

Figura 27: Erro Médio Absoluto (EMA) por categoria de veículo (Cunha, 2007)

Na Figura 27, o parâmetro EMA corresponde à divergência percentual entre os valores de velocidade instantânea coletados e os valores gerados pelo simulador CORSIM (curvas de aceleração default), por um modelo analítico de simulação (Truper), e pelo simulador CORSIM calibrado com o auxílio de um algoritmo genético, que reconstituiu as curvas de aceleração com base nos dados coletados.

Para verificar a consistência dos dados gerados pelo simulador SimVC, optou-se pela verificação dos resultados de simulações e coletas de dados dos trabalhos de Lucic, Cunha, comparações com os resultados gerados pelo modelo Truper e reprodução das curvas de aceleração e desaceleração do HCM. 
Neste trabalho não foi realizada a calibração do simulador para uma situação específica. Por considerar um número de variáveis maior que os demais simuladores, a calibração exigiria um experimento de campo controlado, com medidas da potência instantânea, força no eixo trator, pesagem diferencial dos eixos, levantamento topográfico de uma rodovia teste, e levantamento do perfil de velocidades com GPS diferencial, sendo a prioridade deste trabalho representar com acurácia um maior número de situações possíveis de tráfego, para veículos com configurações variadas.

Nas subseções 3.2.1 a 3.2.4 são descritas as verificações realizadas. $\mathrm{Na}$ subseção 3.2.5 se apresenta um resumo das verificações realizadas e conclui-se pela aceitação dos resultados gerados pelo algoritmo de SimVC. 


\subsubsection{Curvas do HCM}

As curvas de aceleração e desaceleração propostas pelo Highway Capacity Manual - HCM são utilizadas na definição de comprimentos de faixas de aceleração e desaceleração em projetos de rodovias americanas. Na falta de referências nacionais, o DNIT recomenda a utilização dessas curvas em seu manual de projeto de rodovias.

Neste contexto, buscou-se com o simulador SimVC reproduzir as mesmas curvas, adotando um veículo com características semelhantes às do veículo tipo proposto no HCM, com relação potência massa de $11 \mathrm{cv} / \mathrm{t}$ (200lb/hp), um trecho de rodovia hipotético de 5.000 metros com inclinações variando de 0 a $8 \%$, e velocidades iniciais de 0 e $89 \mathrm{~km} / \mathrm{h}(55 \mathrm{mi} / \mathrm{h})$.

Os resultados das simulações são apresentados na Figura 28, cuja divergência máxima observada entre as curvas do HCM (Figura 4) e as geradas pelo simulador foi de $5 \mathrm{~km} / \mathrm{h}$.

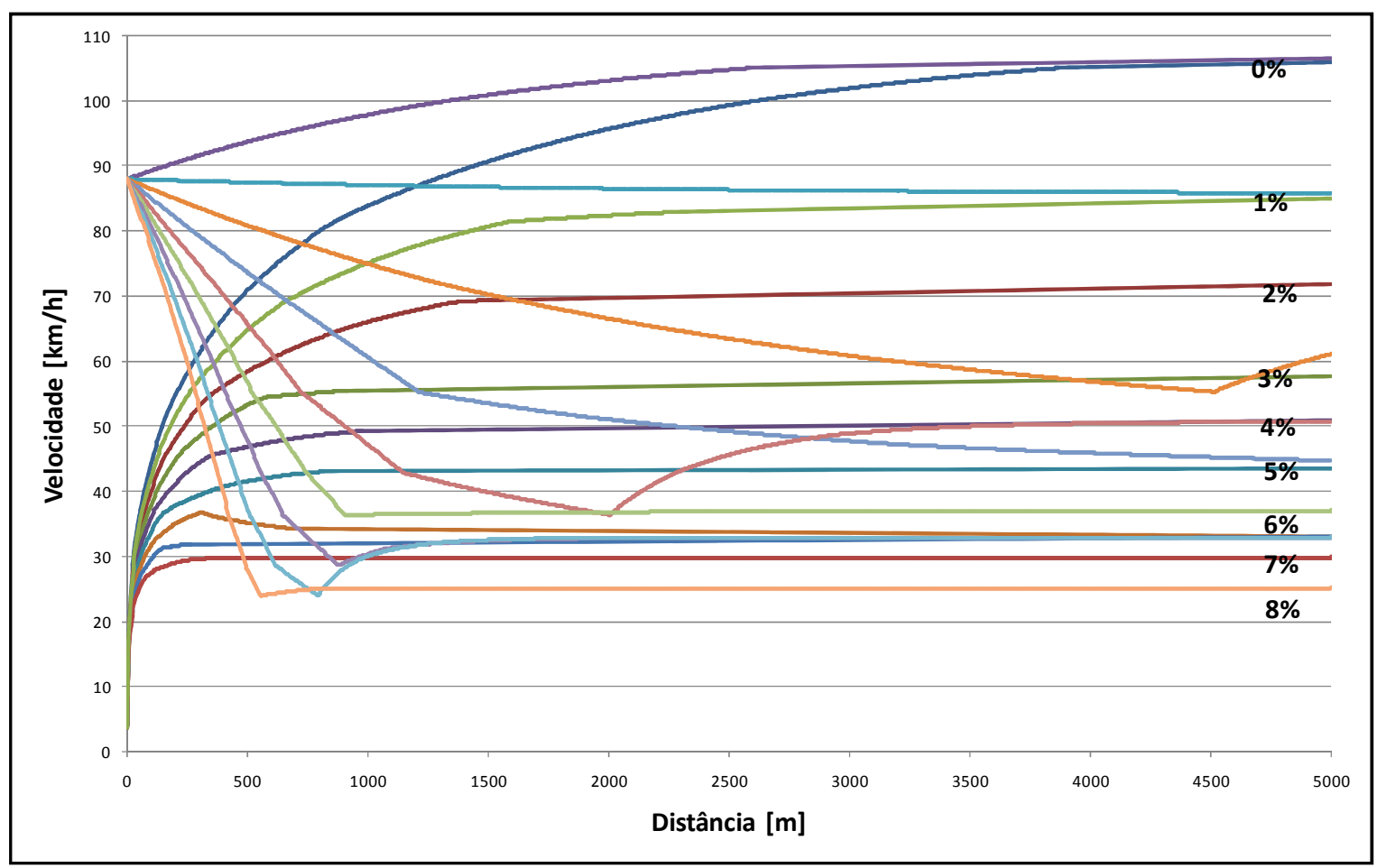

Figura 28: Curvas de aceleração e desaceleração de SimVC para veículo com 
Os resultados alcançados permitem identificar flutuações nas velocidades antes de atingir a velocidade de equilíbrio para cada greide, tanto nas curvas de aceleração quanto de desaceleração, devido à necessidade de mudança de marcha, o que evidencia a possibilidade do condutor obter em campo curvas de aceleração semelhantes às simuladas, devido à escolha do momento (rotação) em que efetua a troca de marcha.

A similaridade das curvas propostas pelo manual de projeto e as curvas simuladas também deve ser vista com a ressalva de que o condutor utiliza a potência máxima disponível, o que em situações reais de tráfego nem sempre ocorre. A conseqüência disto é o projeto de pistas de aceleração e desaceleração menores que as necessárias para atender diferentes veículos.

Outro ponto a ser observado é a relação potência/massa utilizada. De acordo com a distribuição dessa para caminhões observados por Cunha (2007), como mostra a Figura 1,75\% dos veículos extra-pesados (7 ou mais eixos) e $60 \%$ dos veículos pesados ( 5 e 6 eixos) possuem valores inferiores a $11 \mathrm{cv} / \mathrm{t}$. 


\subsubsection{SimVC x Truper}

A segunda verificação foi comparar os resultados gerados pelo simulador Truck Performance - Truper, com os resultados de SimVC, em um trecho plano de $1.500 \mathrm{~m}$, para veículos que partem do repouso e buscam a velocidade máxima, semelhante às curvas de aceleração do HCM.

Para o simulador Truper foi adotado o modelo com troca de marchas, com incrementos de tempo entre iterações de 0,10s e incrementos de velocidade de $0,50 \mathrm{~km} / \mathrm{h}$ para exibição dos resultados. Foram realizadas comparações para aceleração de quatro veículos, descritos na Tabela 7.

\section{Tabela 7: Características dos veículos simulados}

\begin{tabular}{|c|c|c|c|c|}
\hline Veículo & 1 & 2 & 3 & 4 \\
\hline Configuração & U12 & 11 S2 & 12S3B3 & U12A1S1 \\
\hline PBTC (t) & 23 & 33 & 74 & 43 \\
\hline Pot (cv) & 218 & 206 & 370 & 136 \\
\hline № marchas & 6 & 6 & 16 & 6 \\
\hline
\end{tabular}

Apesar de o simulador Truper utilizar as curvas de potência do motor dos veículos para prever seu desempenho, difere do algoritmo de SimVC quanto a determinação da rotação para troca de marchas. O primeiro efetua a troca de acordo com uma relação entre os valores das reduções das marchas, conhecida por slipt ratio. O segundo permite ao usuário fixar as rotações máxima e mínima de operação, escolhendo assim a rotação em que é efetuada a mudança de marcha.

A Figura 29 exibe o resultado das simulações. 


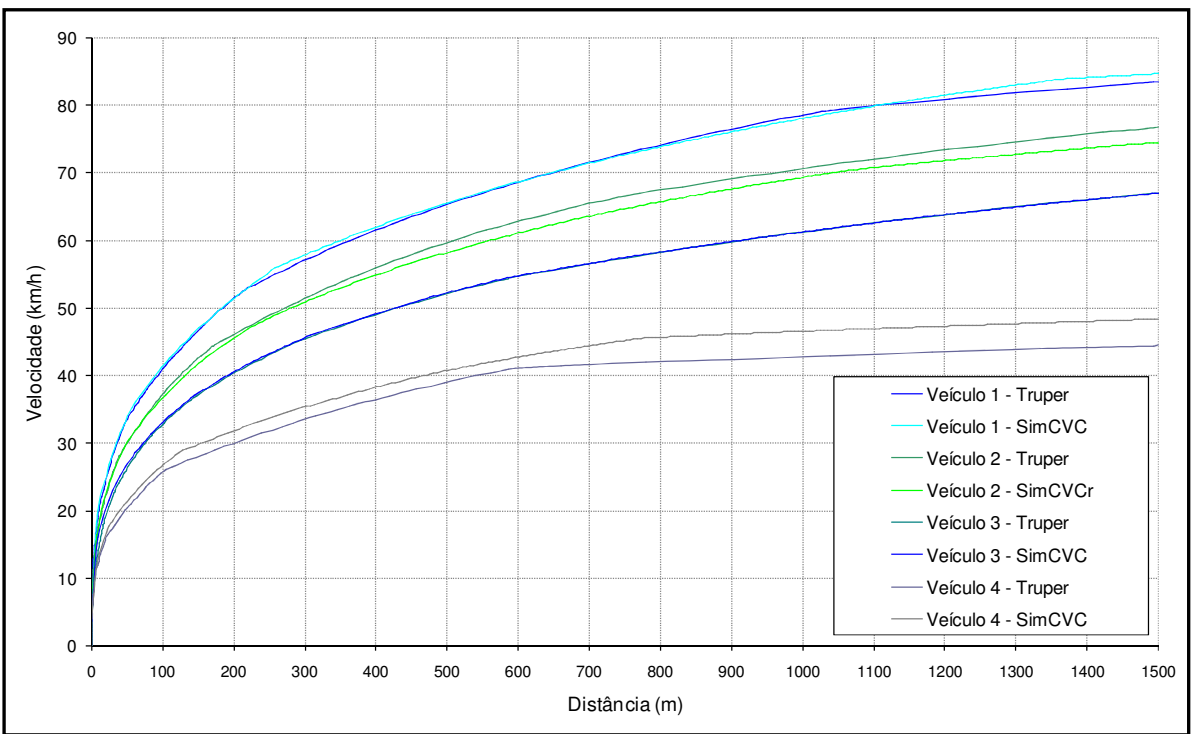

Figura 29: Comparação entre perfil de velocidades: Truper x SimVC

Os resultados gerados por ambos os simuladores são praticamente coincidentes, sendo a maior diferença de velocidade observada para o Veículo 4, ao final do trecho, de $4 \mathrm{~km} / \mathrm{h}$.

A escolha do trecho plano para comparação dos resultados foi feita de com o objetivo de minimizar o impacto da resistência de rampa $\left(R_{g}\right)$, sendo esta uma das principais determinantes sobre o desempenho dos veículos. Desta forma, a proximidade dos resultados sem o efeito da resistência de rampa, indica a coerência do algoritmo desenvolvido com o do software já aceito nos trabalhos científicos. 


\subsubsection{SimVC x Dados coletados}

Cunha (2007) coletou, com auxílio de um aparelho GPS, dados de veículos de carga que transitavam em rodovias paulistas, determinando a velocidade instantânea e posição com que trafegavam por um trecho de rodovia. O PBTC foi registrado em um posto de pesagem (balança) da rodovia, sendo também anotados número de eixos, modelo da unidade tratora e potência motora nominal acoplada.

A terceira verificação consistiu em reproduzir esses perfis de velocidade com o auxílio do SimVC. Características mecânicas de catálogo compatíveis com os modelos de unidades tratoras dos veículos estudados foram utilizadas na geração dos cenários de simulação.

As características dos seis veículos cujos perfis de velocidade foram coletados são apresentadas na Tabela 8.

Tabela 8: Característica dos veículos utilizados na coleta de dados

\begin{tabular}{|c|c|c|c|c|c|c|}
\hline Parâmetro & Coleta 1 & Coleta 2 & Coleta 3 & Coleta 4 & Coleta 5 & Coleta 6 \\
\hline Motor (cv) & 420 & 400 & 380 & 380 & 380 & 360 \\
\hline PBTC (t) & 58,8 & 59,8 & 60,0 & 58,5 & 58,7 & 58,2 \\
\hline $\begin{array}{c}\text { Pot/Massa } \\
\text { (cv/t) }\end{array}$ & 7,14 & 6,69 & 6,32 & 6,50 & 6,47 & 6,18 \\
\hline
\end{tabular}

A Figura 30 apresenta os perfis de velocidade coletados com auxílio de um GPS topográfico. 


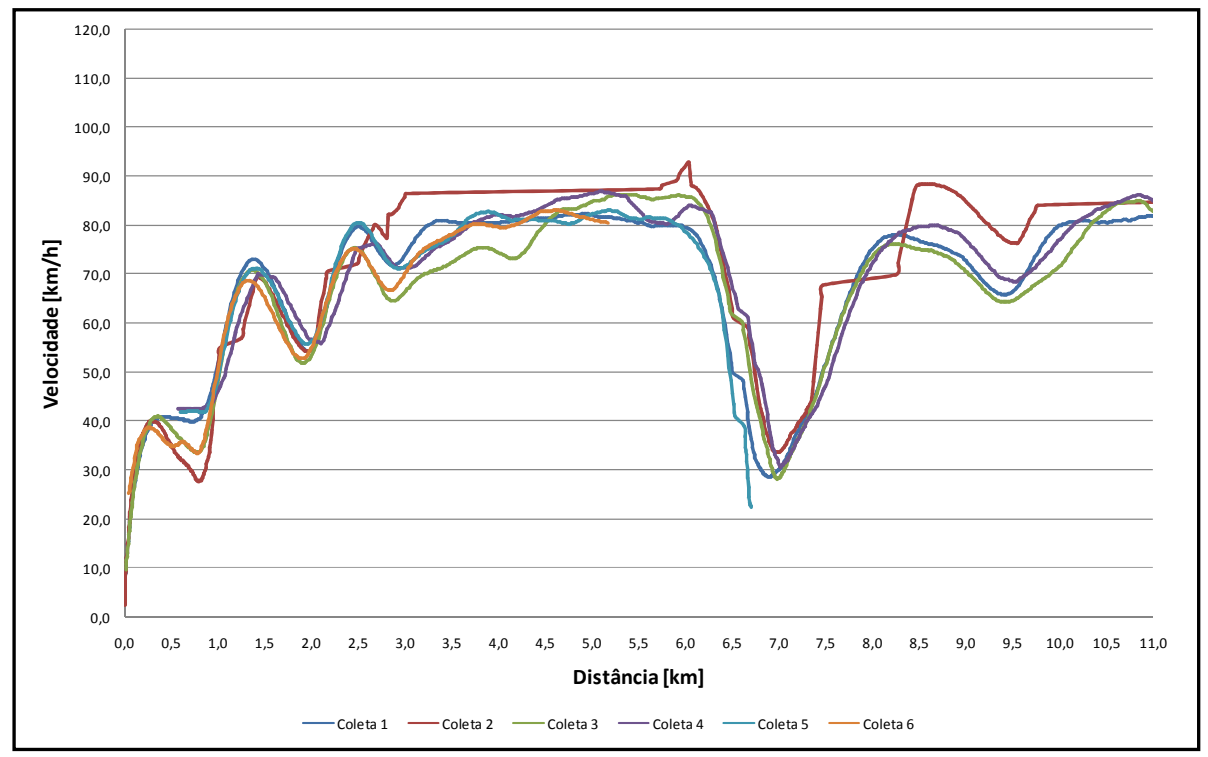

Figura 30: Perfis de velocidade coletados ao longo de rodovia de pista dupla

Adotando-se o perfil geométrico do trecho de rodovia onde a coleta foi efetuada (SP-310), realizou-se simulações com veículos e características operacionais semelhantes aos dos dados coletados, como mostra a Tabela 9.

Tabela 9: Características dos veículos simulados

\begin{tabular}{|c|c|c|c|c|}
\hline Parâmetro & Sim 1 & Sim 2 & Sim 3 & Sim 4 \\
\hline Motor (cv) & 230 & 310 & 360 & 420 \\
\hline PBTC (t) & 60 & 60 & 60 & 60 \\
\hline Pot/Massa (cv/t) & 3,84 & 5,17 & 6,01 & 7,01 \\
\hline Perfil do & $100 \%$ & $100 \%$ & $100 \%$ & $100 \%$ \\
\hline Condutor (\%) & & & & \\
\hline
\end{tabular}

A Figura 31 mostra os perfis de velocidades das quatro simulações, que admitem o veículo trafegando livremente, sem qualquer outra limitação de desempenho senão suas limitações mecânicas e as impostas pela geometria (perfil vertical) da via. 


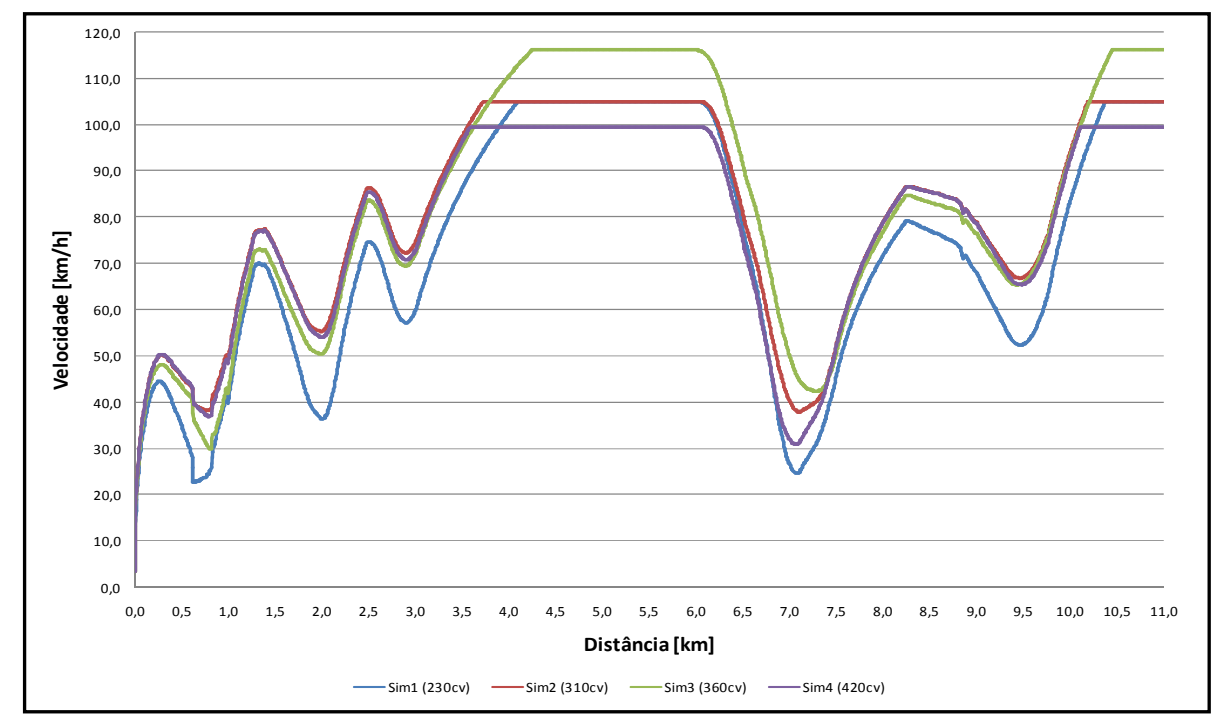

Figura 31: Perfis de velocidades obtidos nas simulações

Entretanto, como nos dados apresentados na Figura 30 os veículos concentram suas velocidades máximas entre $80 \mathrm{~km} / \mathrm{h}$ e $90 \mathrm{~km} / \mathrm{h}$, patamar de velocidade factível de ser alcançado, repetimos as simulações acrescentando um limite de velocidade de $90 \mathrm{~km} / \mathrm{h}$. Os resultados são apresentados na Figura 32.

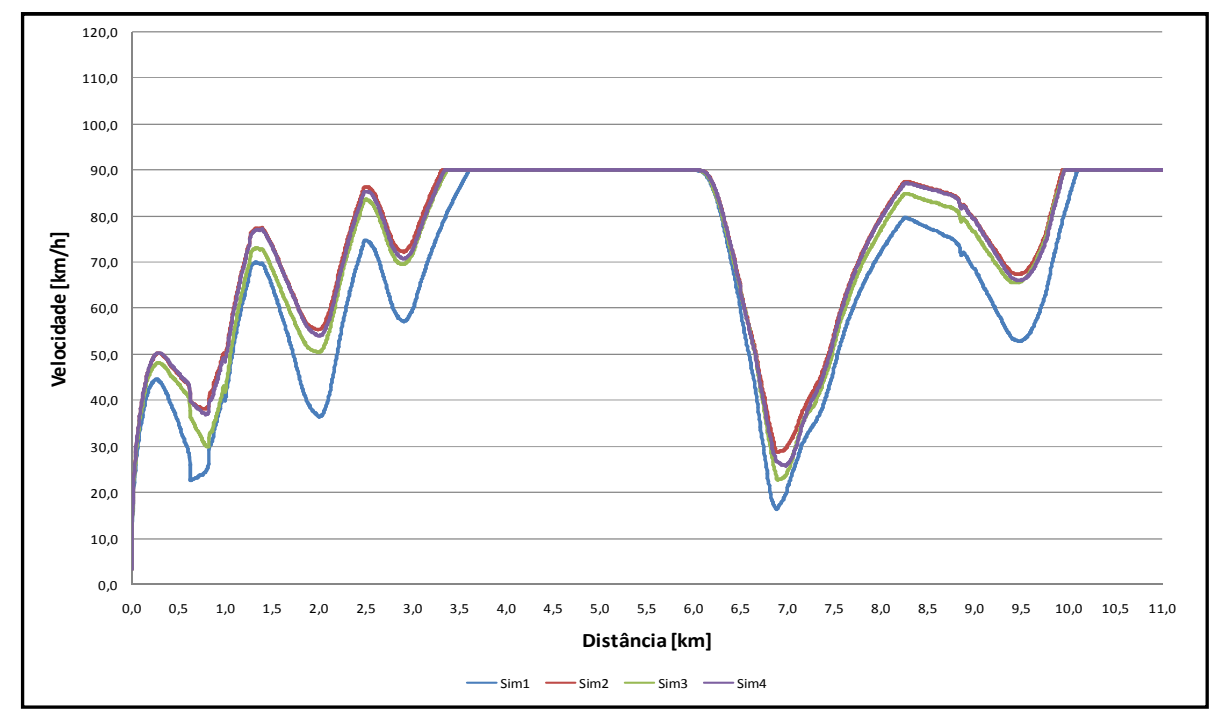

Figura 32: Simulações com limitação de velocidade de $90 \mathrm{~km} / \mathrm{h}$

Observa-se que a imposição do limite de velocidade leva a uma representação compatível com os dados apresentados na Figura 30. Foram realizadas simulações adicionais, variando o perifl do condutor, admitindo a utilização de $100 \%, 90 \%$ e $80 \%$ da potência disponível. Os resultados são apresentados na Figura 33. 


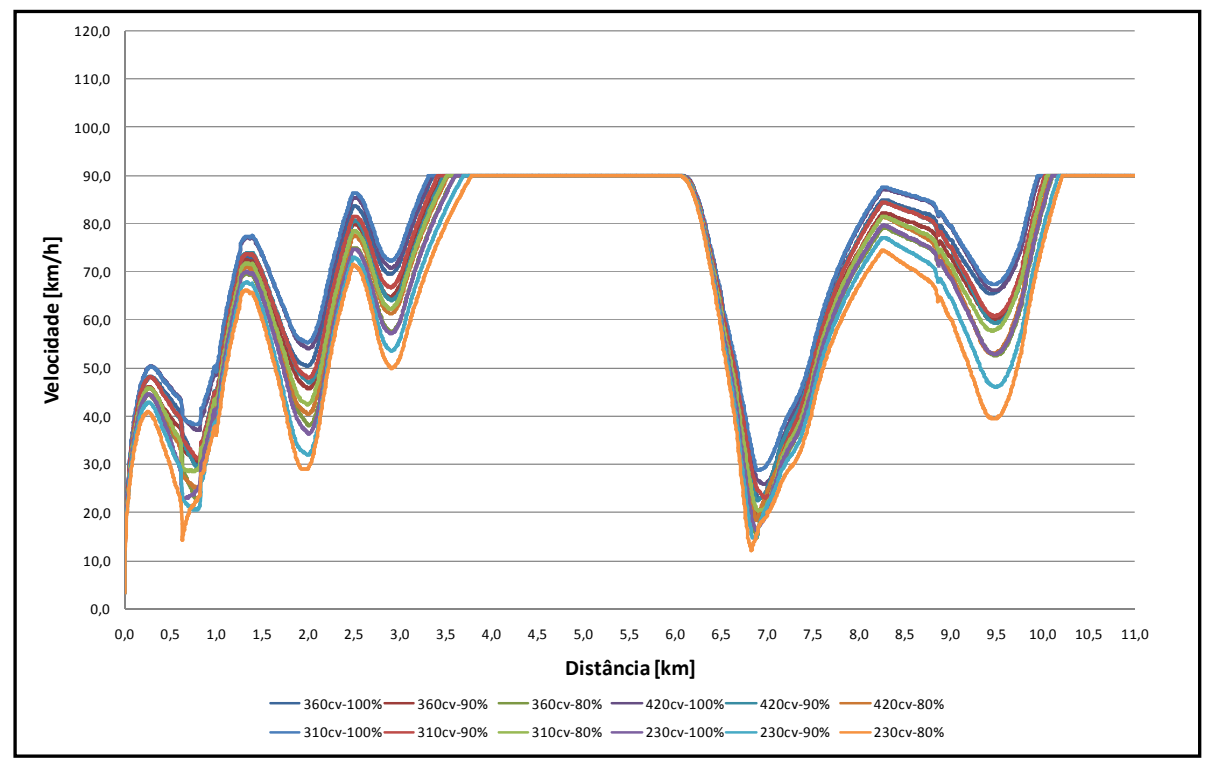

Figura 33: Simulações com interferência do condutor

A faixa de velocidades definida pelo conjunto das curvas de velocidade em função da distância percorrida mostradas na Figura 33 é compatível com a faixa de velocidade formada pelos perfis coletados da Figura 30. Para uma precisão de $10 \mathrm{~km} / \mathrm{h}$, as situações de campo são bem representadas pelas de simulação, especialmente os pontos críticos, em que ocorrem as mudanças de aceleração, associadas a inversões no perfil longitudinal de aclive para declive e vice-versa.

Para calibração do simulador e comparações estatísticas como a determinação do Erro Médio Absoluto (EMA), semelhantes às realizadas por Cunha (2007), faz-se necessário um levantamento mais detalhado dos veículos instrumentados, contendo as relações da caixa de mudanças e do diferencial, eficiência da transmissão e curvas de potência do motor.

Ainda assim, persistiria a imprevisibilidade do comportamento do condutor, pois como mostra a Figura 33, variações de velocidade entre $5 \mathrm{~km} / \mathrm{h}$ e $10 \mathrm{~km} / \mathrm{h}$, para um mesmo veículo, podem ser atribuídas pela redução da potência utilizada pelo condutor, de 100 para $80 \%$. 


\subsubsection{Curvas de Aceleração}

A quarta verificação foi reproduzir as curvas de aceleração utilizadas para calibrar modelo semelhante desenvolvido na dissertação de mestrado de Lucic (2001). Em seu trabalho utilizou uma CVC tipo 12S3 (cavalo mecânico de três eixos e semi-reboque de três eixos), com dez combinações de carregamentos, em um trecho teste de $1,5 \mathrm{~km}$ de extensão, cujas inclinações são apresentadas na Figura 34.

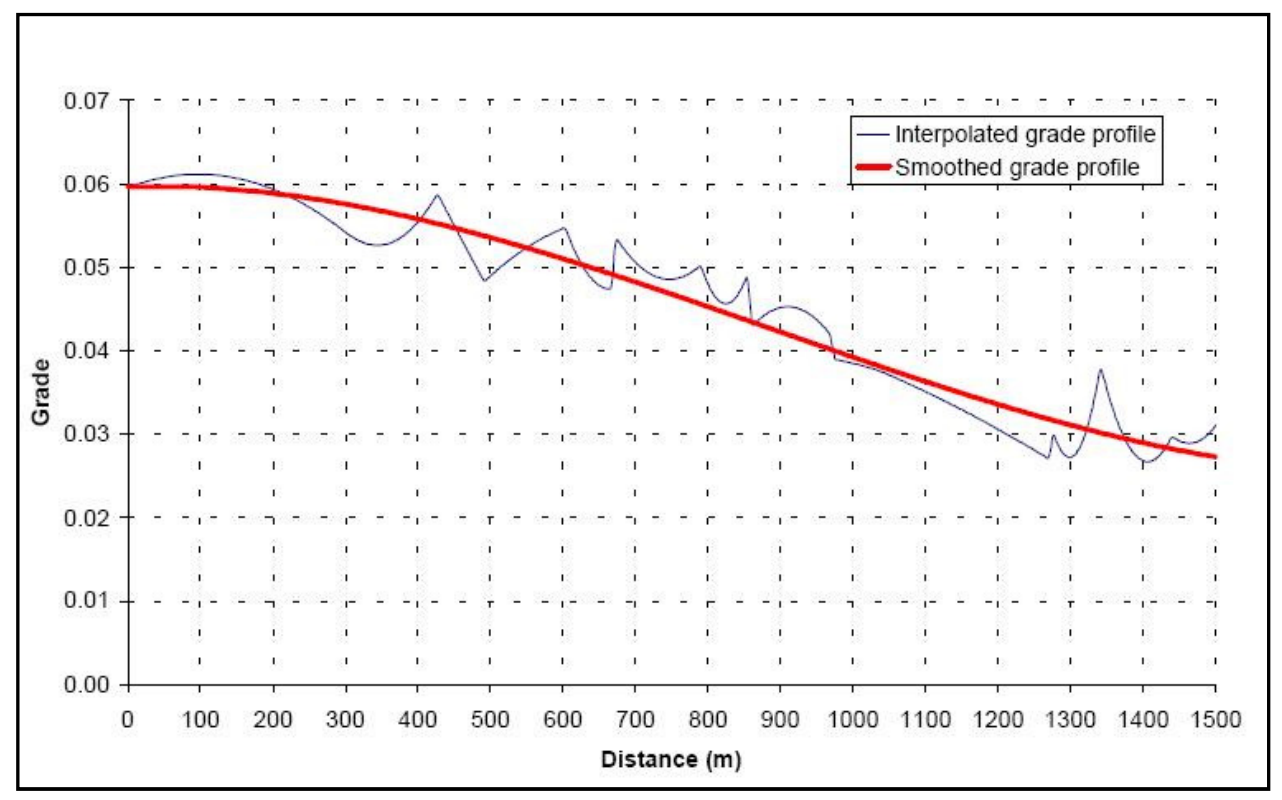

Figura 34: Inclinações do perfil vertical ao longo do trecho (Lucic, 2001)

Na situação analisada, o veículo parte do repouso e acelera o máximo possível até o final do trecho, enquanto a velocidade é registrada a cada segundo por um aparelho GPS. O veículo teste utilizado por Lucic estava equipado com um motor Cummins NTC - 350 (350 hp ou 261 kW ou 350cv), com torque máximo de 1627 N.m a 1300 rpm.

As combinações de peso bruto total combinado foram obtidas com o acréscimo de blocos de concreto (2.400kg cada) para aumentar a carga, sendo obtidas as seguintes combinações de PBTC (t): 22; 25; 28; 31; 32; 34; 35; 38; 41 e 44 , o que corresponde a variações da relação potência/massa de $85 \mathrm{~kg} / \mathrm{kW}$ ou $15 \mathrm{cv} / \mathrm{t}$ a $168 \mathrm{~kg} / \mathrm{kW}$ ou $7 \mathrm{cv} / \mathrm{t})$. Os demais coeficientes utilizados são apresentados 
no Anexo D. Para cada configuração de PBTC foram realizadas dez repetições de aceleração livre, partindo do repouso. A Figura 35 apresenta as curvas de aceleração registradas para a configuração com 25 t, bem como a curva da simulação correspondente.

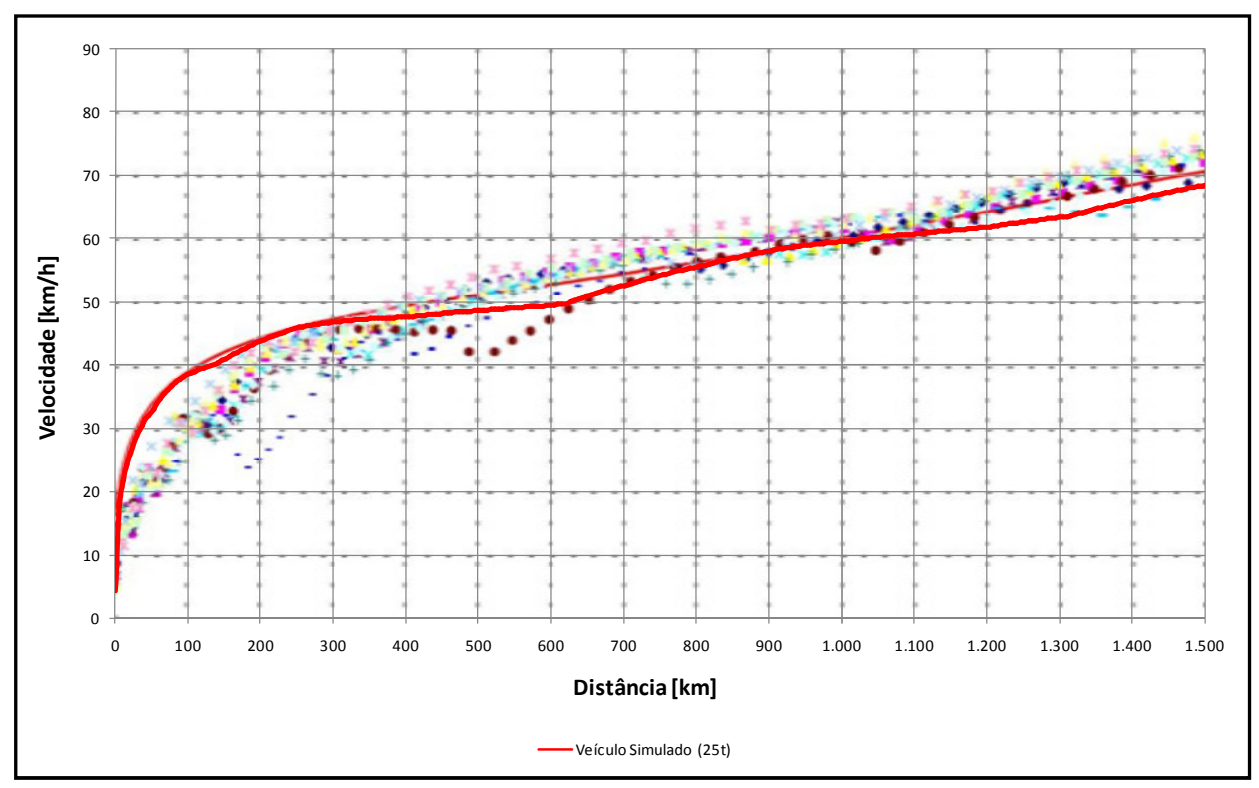

Figura 35: Dados coletados e curva simulada (PBTC 25t)

Para a configuração com 44t, os dados coletados e o resultado da simulação são os apresentados na Figura 36.

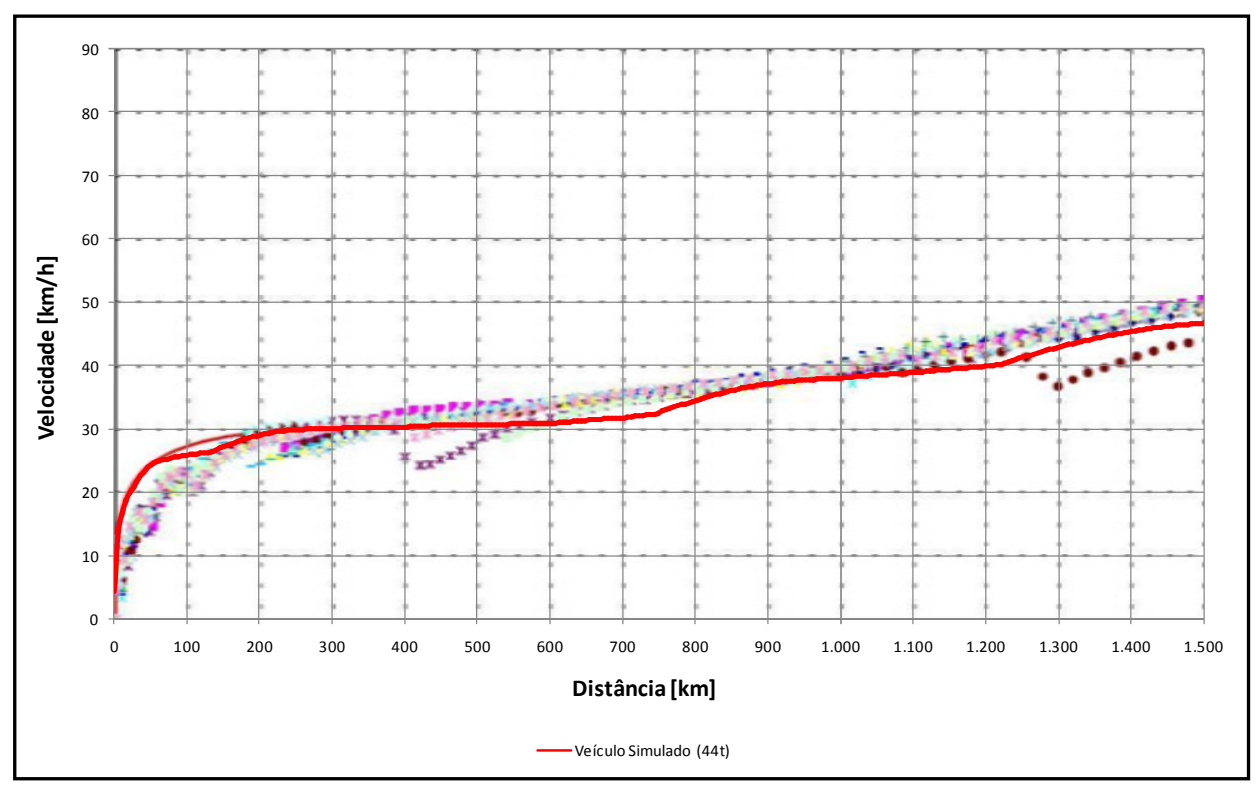

Figura 36: Dados coletados e curva simulada (PBTC 44t) 
Os resultados gerados pelas simulações mostram-se condizentes com os dados coletados. A variação da curva simulada (cor vermelha) em relação às observações no início do percurso, primeiros $1.000 \mathrm{~m}$, também foi observada na pesquisa de Lucic, que atribui essa variação a uma subutilização pelo condutor da potência disponível, uma vez que o mesmo está ocupado com as mudanças de marcha que ocorrem em um curto espaço de tempo.

Dentro do grau de acurácia esperado, entretanto, as divergências entre a curva simulada e os dados coletados foram consideradas aceitáveis, podendo ser tribuídas à forma e ao momento das mudanças de marcha e ao grau de incerteza dos dados do veículo utilizado na coleta de dados, tais como: os valores exatos das reduções do diferencial, da caixa de mudanças, e a curva de potência do motor, sendo disponibilizados apenas a potência nominal do motor, a área frontal do veículo, a carga e os coeficientes de resistência ao movimento. 


\subsection{Análise complementar}

As seções 3.1, 3.2 e 3.3 demonstraram a consistência dos resultados gerados pelo simulador com dados coletados em campo e curvas de aceleração do manual de projeto de rodovias da AASHTO e do DNIT.

Considerando a repetibilidade das curvas de aceleração e desaceleração do manual de projeto do HCM (2004), a reprodução da curva de aceleração determinada com dados observados em campo por Lucic (2001), a consistência com os dados gerados pelo simulador Truper, e a reprodução dos perfis de velocidade observados por Cunha (2007), pode-se afirmar que o modelo proposto reproduz com boa acurácia o desempenho de veículos de carga em rodovias.

Os principais fatores que afetam as simulações são o PBTC, a potência motora acoplada e o perfil longitudinal dos trechos de rodovia, seguidos da correta escolha das relações de redução da caixa de mudanças e do diferencial. As não conformidades desses parâmetros geram distorções nas simulações, principalmente quando o objetivo é reproduzir dados coletados em campo, com elevado grau de incerteza sobre as reais características mecânicas a que se referem esses dados.

A taxa de utilização da potência motora e a rotação escolhida pelo condutor para efetuar a troca de marchas também provocam divergências entre os resultados, que podem ser propagadas para os cálculos de consumo de combustível e emissão de poluentes. Desta forma, é razoável afirmar que o modelo é válido para caminhões unitários e CVCs com baixas relações potência/massa, entre 5 e $25 \mathrm{cv} / \mathrm{t}$, pois veículos médios e leves $(>25 \mathrm{cv} / \mathrm{t})$ permitem ao condutor maior liberdade para escolher a velocidade de trajeto, assim como as acelerações e desacelerações ao longo do trecho, pois o limitante não é a capacidade motora do veículo.

Algumas considerações pouco abordadas nos trabalhos com simuladores até então desenvolvidos são avaliadas abaixo: 
1) Incremento de tempo do simulador: é o intervalo de tempo real para o qual o simulador admite constantes as condições de aceleração e configuração do veículo e da via. A aceleração é admitida como constante e o movimento é uniformemente acelerado, cuja relação matemática obedece às formulações da mecânica newtoniana. $O$ incremento de tempo adotado nesta pesquisa foi de 0,1 segundo, que corresponde a um deslocamento de 2,7 metros para um veículo que trafega a $100 \mathrm{~km} / \mathrm{h}(\sim 27,7 \mathrm{~m} / \mathrm{s})$.

2) Impressão dos resultados: os resultados calculados em cada iteração (rotação, potência, velocidade, etc) são impressos em linhas de uma planilha Excel segundo um critério adotado pelo pesquisador, neste caso, um deslocamento máximo de 5 metros.

3) Tempo entre troca de marchas: é possível inserir um tempo entre troca de marchas, no qual o veículo é acelerado somente pelas forças de resistência ao movimento, não havendo tração motora. Nesse caso, o tempo considerado foi de 1,5 segundos em cada troca de marchas.

4) Início da simulação com velocidade nula: ao iniciar o movimento, partindo do repouso, o veículo é acelerado por uma força inferior à máxima disponível, uma vez que o acionamento da primeira marcha ainda não foi totalmente concluído, existindo um período de arranque inicial. Por simplificação, o simulador calcula a velocidade mínima (em geral, inferior a $5 \mathrm{~km} / \mathrm{h}$ ) para a primeira marcha, e adiciona um tempo de 2,0 segundos no início da simulação.

5) Velocidade de equilíbrio: quando ocorre equilíbrio entre as forças de resistência ao movimento e a força de tração que a unidade tratora é capaz de desenvolver, o veículo atinge a chamada velocidade de equilíbrio, em que a aceleração aproxima-se de zero, permanecendo nesta situação até que haja alguma mudança no cenário de simulação, como uma mudança do greide da pista.

6) Aceleração em declives: nos declives, muitas vezes o veículo atinge sua velocidade operacional máxima, limitada pela rotação do motor e pelo valor da 
menor redução disponível na caixa de mudanças, mesmo possuindo potência livre para continuar acelerando. Nesse caso, o simulador reduz a potência fornecida pelo motor a fim de buscar a situação de equilíbrio de forças (aceleração nula). $O$ simulador permite também inserir um limite legal de velocidade máxima no percurso.

7) Aceleração lateral em curvas horizontais: a aceleração em curvas horizontais é desprezada neste tipo de simulação, embora seja restritiva em muitas operações, como em regiões com curvas acentuadas, onde limites devem ser considerados.

8) Interpolação da curva de potência contra rotação: o simulador adota potências intermediárias às fornecidas pelo banco de dados. As curvas de potência contra rotação são cadastradas no banco de dados, sendo um valor de potência para cada valor de rotação, de $100 \mathrm{em} 100 \mathrm{rpm}$. Durante a simulação ocorre a necessidade de calcular a potência para rotações não cadastradas, o que é realizado mediante cálculo de interpolação linear.

Mesmo incorporando esses refinamentos, a acurácia dos resultados está condicionada à liberdade do operador de determinar a aceleração do veículo, o que pode, em certas condições, limitar a representação da operação real. Tal fato, entretanto, não invalida os resultados, que buscam determinar as condições máximas de desempenho de veículos em trechos de rodovias, ou seja, situações nas quais o operador busca as acelerações mais elevadas possíveis para minimizar a interferência na corrente de tráfego.

As simulações mostram também que é possível estabelecer diferenças de desempenho entre veículos, permitindo assim avaliar medidas de desempenho que, mediante a aplicação de um critério de restrição de tráfego, seja por parte dos órgãos regulamentadores ou operadores da via, auxiliem na decisão de restringir ou não o tráfego de caminhões e CVCs, tendo por base um critério técnico. 


\section{ANÁLISES DE COMPATIBILIDADE}

O simulador desenvolvido no Capítulo 3 constitui uma ferramenta de análise de compatibilidade de tráfego de caminhões e CVCs em trechos de rodovia. Contudo, os resultados gerados pelo método são válidos dentro de condições de operação definidas. A extrapolação dos resultados para outras condições, assim como a certificação de toda a operação deve ser pautada em estudos mais aprofundados, considerando as peculiaridades de cada situação.

A seguir são apresentadas cinco análises de compatibilidade de tráfego e discussões complementares pertinentes a cada uma delas.

\subsection{Veículos compatíveis com um trecho de rodovia}

Este estudo tem por objetivo avaliar a certificação associada ao desempenho de CVCs. Para isto, cinco veículos foram analisados operando num trecho da rodovia SP-127, entre as cidades de Rio Claro e Piracicaba, cujo perfil geométrico foi obtido por levantamento com GPS cinemático, em trabalho complementar desenvolvido por Lotti (2002).

Foram selecionados veículos que comumente circulam nas rodovias brasileiras (unitários com 2 e 3 eixos, romeu-e-julieta, unidade tratora e semi-reboque e bi-trem de 7 eixos). Duas situações foram estudadas: na primeira os veículos trafegam sem carga e na segunda com sua capacidade total de carregamento (PBTC máximo).

A Tabela 10 apresenta os veículos e as situações avaliadas. Foram estudadas combinações de PBTC entre 8,1 257 toneladas, e relações potência/massa de 6,2 a 25,6 cavalos por tonelada. 


\begin{tabular}{|l|c|c|c|c|}
\hline \multirow{2}{*}{ Veículo } & \multicolumn{2}{|c|}{ Sem carga } & \multicolumn{2}{c|}{ Carregado } \\
\hline & PBTC & $c v / t$ & PBTC & $c v / t$ \\
\hline U11 & 8,1 & 25,2 & 16,0 & 12,8 \\
\hline U12 & 8,5 & 25,6 & 23,0 & 9,4 \\
\hline $11 S 1$ A1S1 & 13,5 & 25,1 & 45,0 & 7,5 \\
\hline $11 S 2$ & 8,2 & 24,9 & 33,0 & 10,3 \\
\hline $11 S 2$ & 13,5 & 25,1 & 33,0 & 6,2 \\
\hline $12 S 2 B 1$ & 13,5 & 25,1 & 50,0 & 6,8 \\
\hline $12 S 2 B 2$ & 16,5 & 25,4 & 57,0 & 7,3 \\
\hline $11 S 3$ & 14,9 & 25,4 & 41,5 & 9,1 \\
\hline
\end{tabular}

O trecho de rodovia estudado tem extensão de $31 \mathrm{~km}$, com o perfil apresentado na Figura 37 (linha tracejada). Na mesma figura são mostrados os perfis de velocidades para os veículos da Tabela 10, na situação sem carga. Os veículos partem do repouso e buscam a velocidade máxima operacional em todo o percurso. Foi considerado um condutor que utiliza $100 \%$ da potência motora disponível, com o objetivo de avaliar o desempenho teórico máximo dos veículos no trecho. 


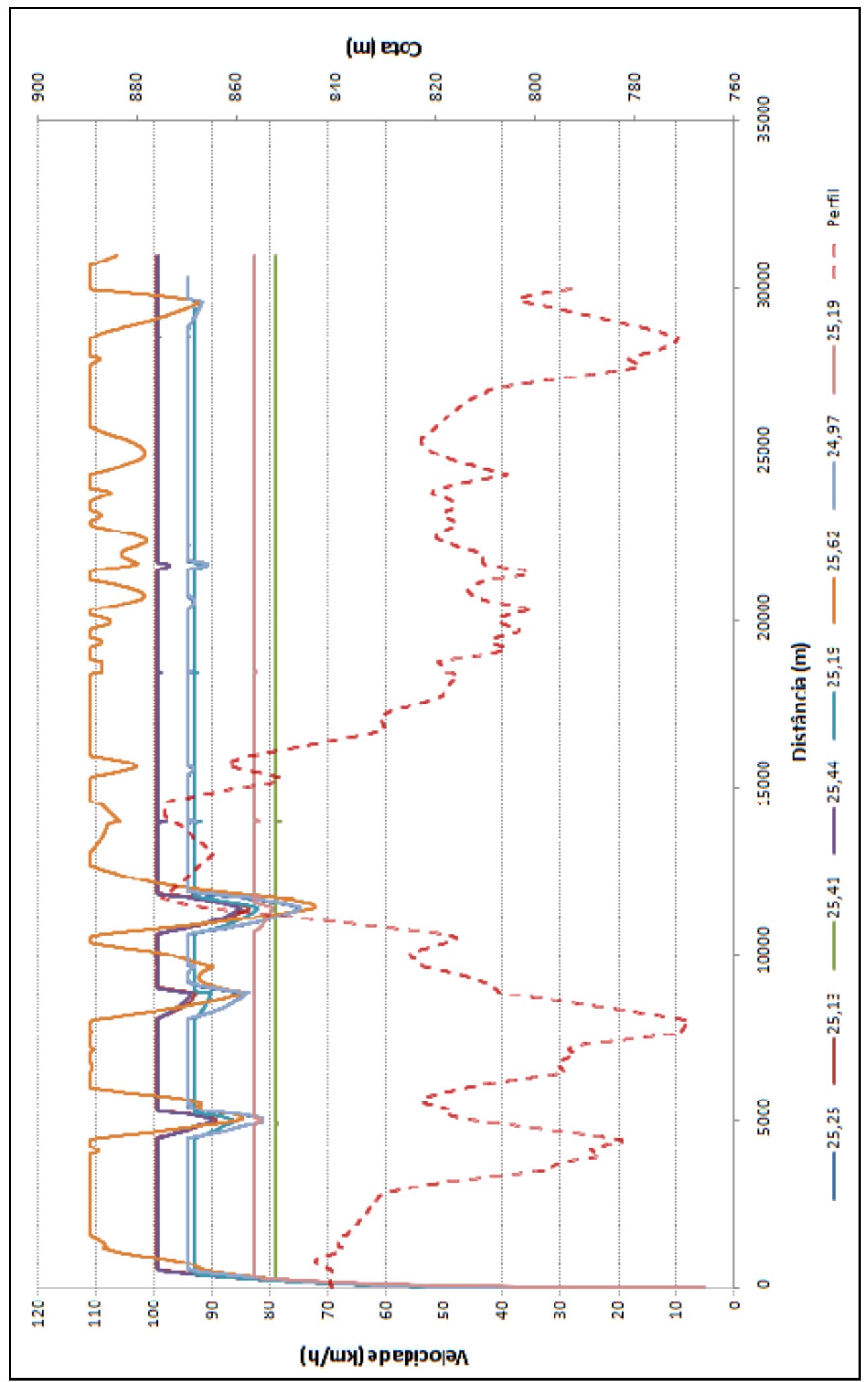

Figura 37: Perfil de velocidades para veículos sem carga 


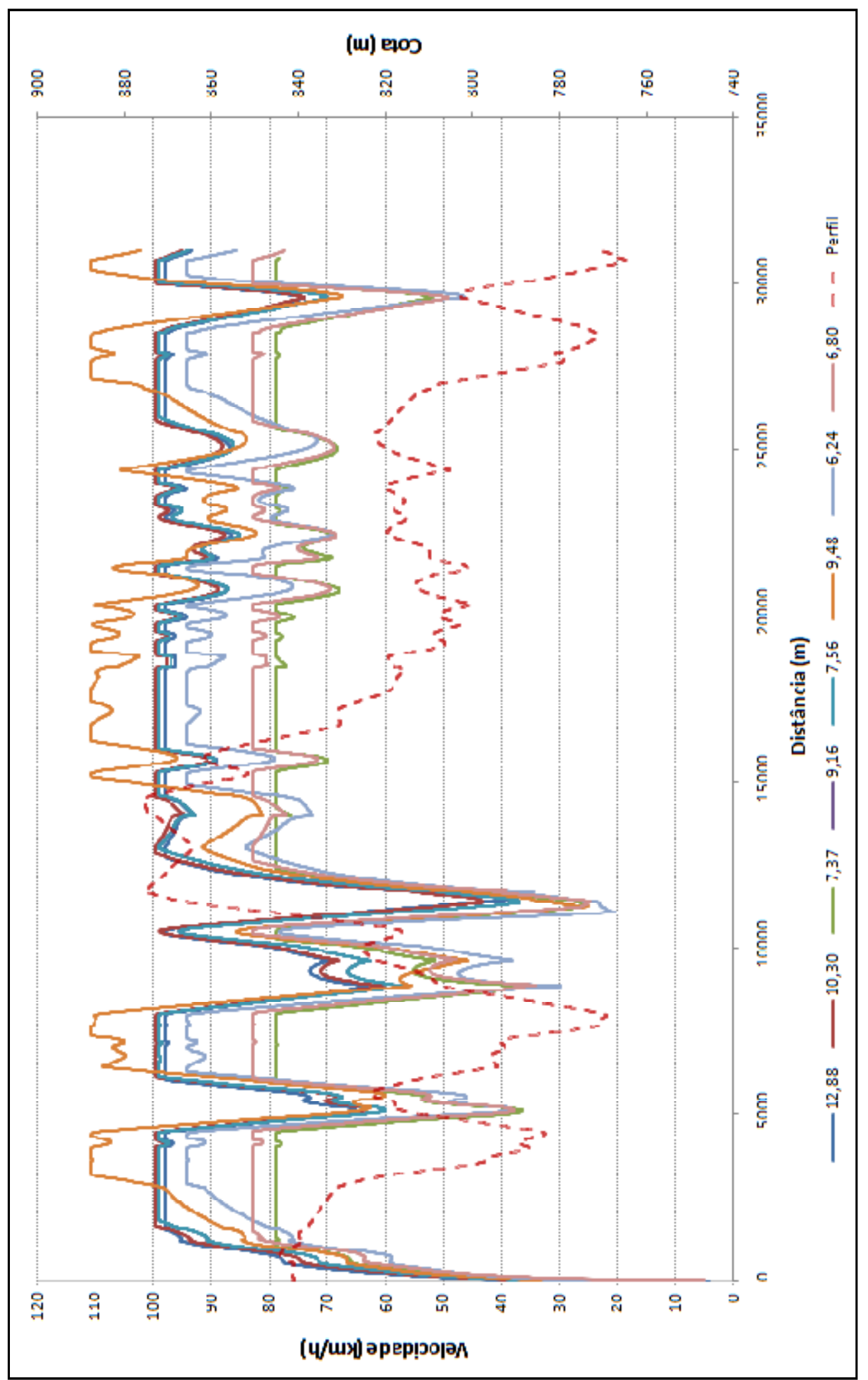

Figura 38: Perfil de velocidades para veículos com carga 
É importante notar que embora os veículos atinjam suas velocidades operacionais máximas, que neste estudo variaram de 80 a $110 \mathrm{~km} / \mathrm{h}$, ao percorrer o trecho crítico da rodovia, onde ocorrem os maiores aclives, têm suas velocidades fortemente reduzidas, com variações para a situação sem carga entre 70 e 90 $\mathrm{km} / \mathrm{h}$.

A Figura 38 apresenta o perfil de velocidades para os veículos da Tabela 10 trafegando com o PBTC máximo permitido. Em ambos os casos, não foi imposto o limite de velocidade máxima legal de $90 \mathrm{~km} / \mathrm{h}$ para caminhões e ônibus, para a rodovia analisada, o que diminuiria ainda mais o desempenho dos veículos.

Para a situação dos veículos operando com a carga máxima permitida, as quedas de velocidade nos trechos de aclive são acentuadas, assim como a distância necessária para os veículos atingirem suas velocidades de equilíbrio nos trechos seguintes aos aclives acentuados, onde ocorre a retomada de velocidade.

Nenhum dos veículos simulados foi capaz de manter a velocidade acima de $45 \mathrm{~km} / \mathrm{h}$ no trecho crítico. O veículo com relação potência/massa de 6,24cv/t apresentou a maior redução de velocidade, chegando a trafegar a $25 \mathrm{~km} / \mathrm{h}$ ao final do aclive crítico. Tais situações não são permitidas pelo artigo 62 do CTB, que para o trecho considerado, com velocidade máxima para caminhões de $90 \mathrm{~km} / \mathrm{h}$, determina que a velocidade mínima seja de $45 \mathrm{~km} / \mathrm{h}$.

Um aspecto crítico sobre a redução da velocidade em função do desempenho insatisfatório das CVCs é o aumento nas diferenças entre velocidades operacionais concorrentes no trecho de rodovia, ou seja, automóveis trafegando na velocidade máxima permitida, em geral a $110 \mathrm{~km} / \mathrm{h}$, e veículos de carga entre 20 e $45 \mathrm{~km} / \mathrm{h}$. O aumento da diferença de velocidade entre veículos que trafegam em um mesmo trecho de rodovia está associado ao número de acidentes, como mostra a Figura 39. 


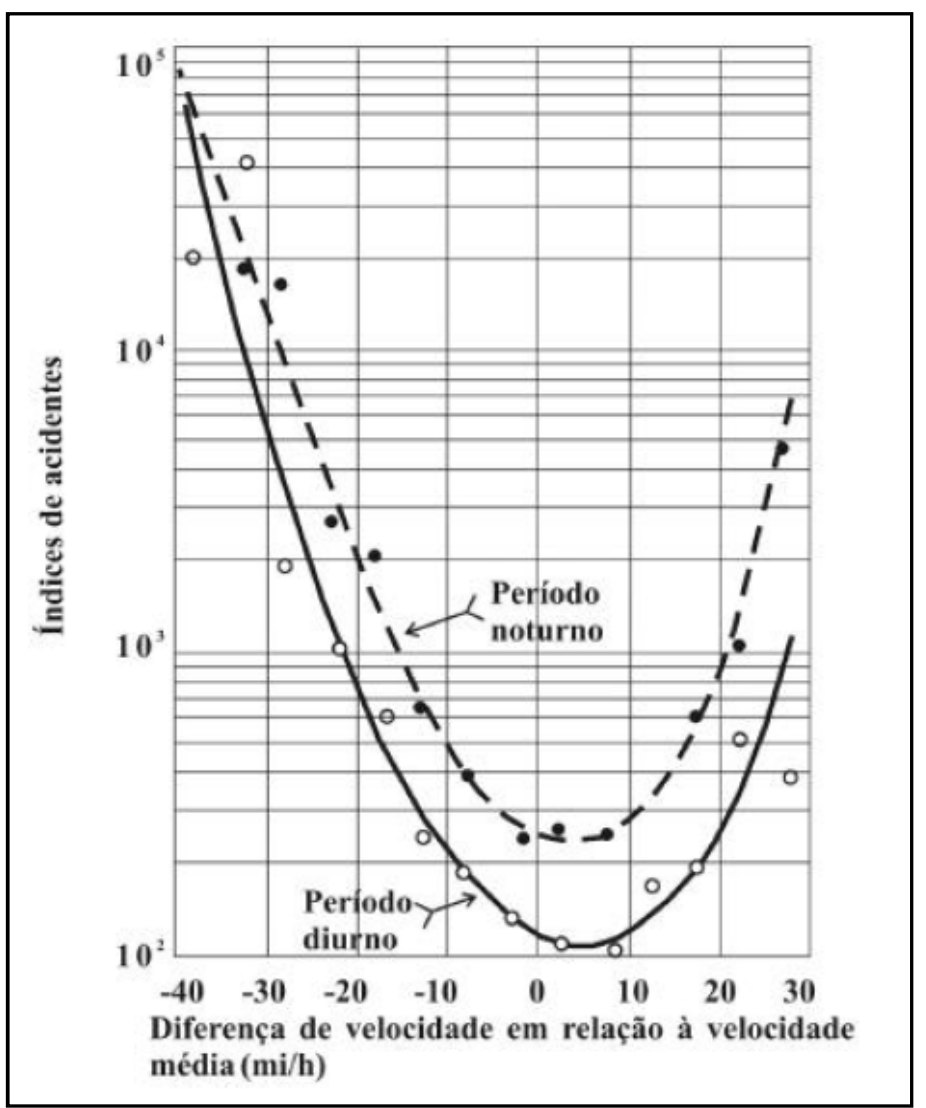

Figura 39: Índice de acidentes e variação da diferença de velocidade média [mph] de automóveis e caminhões (Melo, 2002 apud. Solomon, 1964)

Logo, a permissão de tráfego de veículos incapazes de manter uma velocidade mínima tida como aceitável, constitui um fator contribuinte para o aumento de acidentes no trecho em questão, situação que deve ser evitada.

De posse de estudos como esse, é possível orientar a adoção de medidas de prevenção a acidentes, como redução da velocidade máxima permitida no trecho, construção de faixas auxiliares de tráfego para veículos pesados ou sinalização apropriada para o trecho.

Numa análise crítica do cenário apresentado, praticamente todos os veículos simulados seriam considerados incompatíveis com o tráfego entre os km $10 \mathrm{e}$ 15 do perfil considerado. 


\subsubsection{Certificação de tráfego com intervenção na via}

Considerando que a diferença de velocidade entre veículos deva ser a menor possível e que a velocidade dos veículos não deve ser inferior à metade da velocidade máxima regulamentada, exigência da regulamentação brasileira, a via deve prever dispositivos para minimizar o impacto do tráfego de veículos lentos nos trechos críticos de rodovias. Uma alternativa seria a construção de faixas auxiliares (terceira faixa) para comportar os veículos lentos, além da devida sinalização para o trecho.

A Figura 40 amplia a visualização dos resultados das simulações nos trechos críticos, realizadas na seção anterior (Figuras 37 e 48).

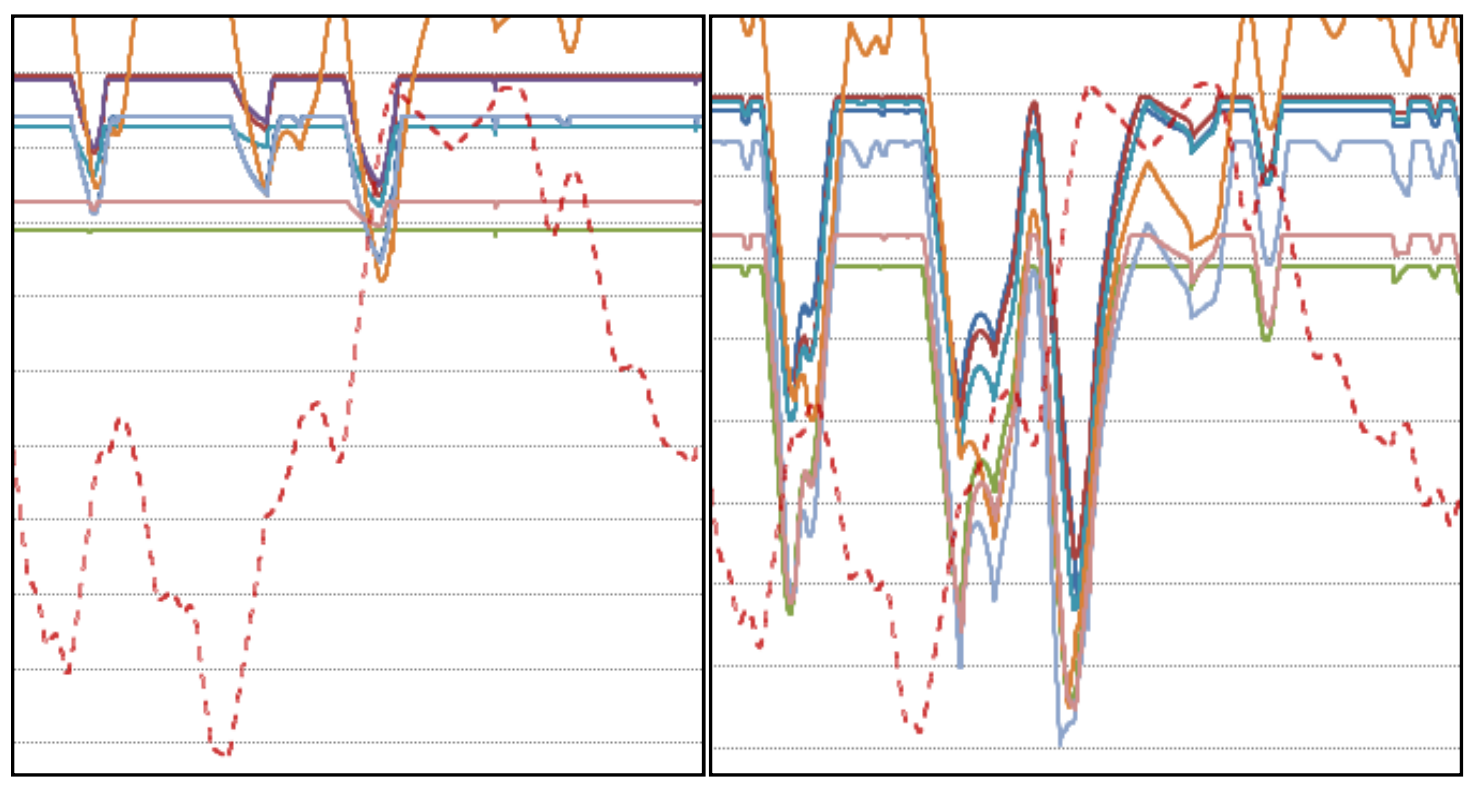

(a)

(b)

Figura 40: Trecho crítico: veículos sem carga (a) e com carga (b)

A Figura 40 explicita as situações possíveis de tráfego para o trecho crítico. É esperado o tráfego de caminhões com velocidades variando de 20 (veículo com carga) a $110 \mathrm{~km} / \mathrm{h}$ (veículo sem carga), além do tráfego de automóveis. A maior ou menor concentração de veículos em cada faixa de velocidades depende de características de tráfego locais, como veículos, cargas e carregamentos típicos, horas-pico de utilização da rodovia por categoria de veículos, etc. 
Uma alternativa à criação da terceira faixa seria a suavização do perfil vertical do trecho de rodovia, solução dispendiosa, cuja justificativa seria um volume de tráfego expressivo de veículos lentos, em que a terceira faixa não surtiria 0 efeito desejado.

Outra possibilidade seria a certificação de tráfego das composições críticas com a utilização de tabelas de horário, de tal forma que seja evitado o tráfego de veículos lentos nas horas-pico de veículos leves.

\subsubsection{Previsão de pontos críticos em projetos de rodovia}

A metodologia pode também ser utilizada na identificação de pontos críticos de projetos de rodovias, através do estudo do perfil geométrico frente aos veículos de projeto ou veículos que potencialmente venham a utilizar a rodovia.

Para exemplificar, foram realizadas simulações com um veículo tipo 12S3B3 (9 eixos), com as seguintes configurações:

1) Motor com potência nominal de $360 \mathrm{cv}$, e três perfis de condutores, que utilizam 100, 90 e $80 \%$ da potência disponível.

2) Motor com potência nominal de $420 \mathrm{cv}$, e três perfis de condutores, que utilizam 100, 90 e $80 \%$ da potência disponível.

Adotou-se um perfil de trecho de rodovia, formado por um declive seguido de dois aclives consecutivos, e velocidade máxima permitida de $90 \mathrm{~km} / \mathrm{h}$.

A Figura 41 apresenta o perfil do trecho de rodovia e as curvas de velocidade obtidas, destacando o trecho em que todas as situações simuladas apresentam desempenho insatisfatório, ou seja, velocidades máximas inferiores a $45 \mathrm{~km} / \mathrm{h}$ (metade da velocidade máxima permitida). 


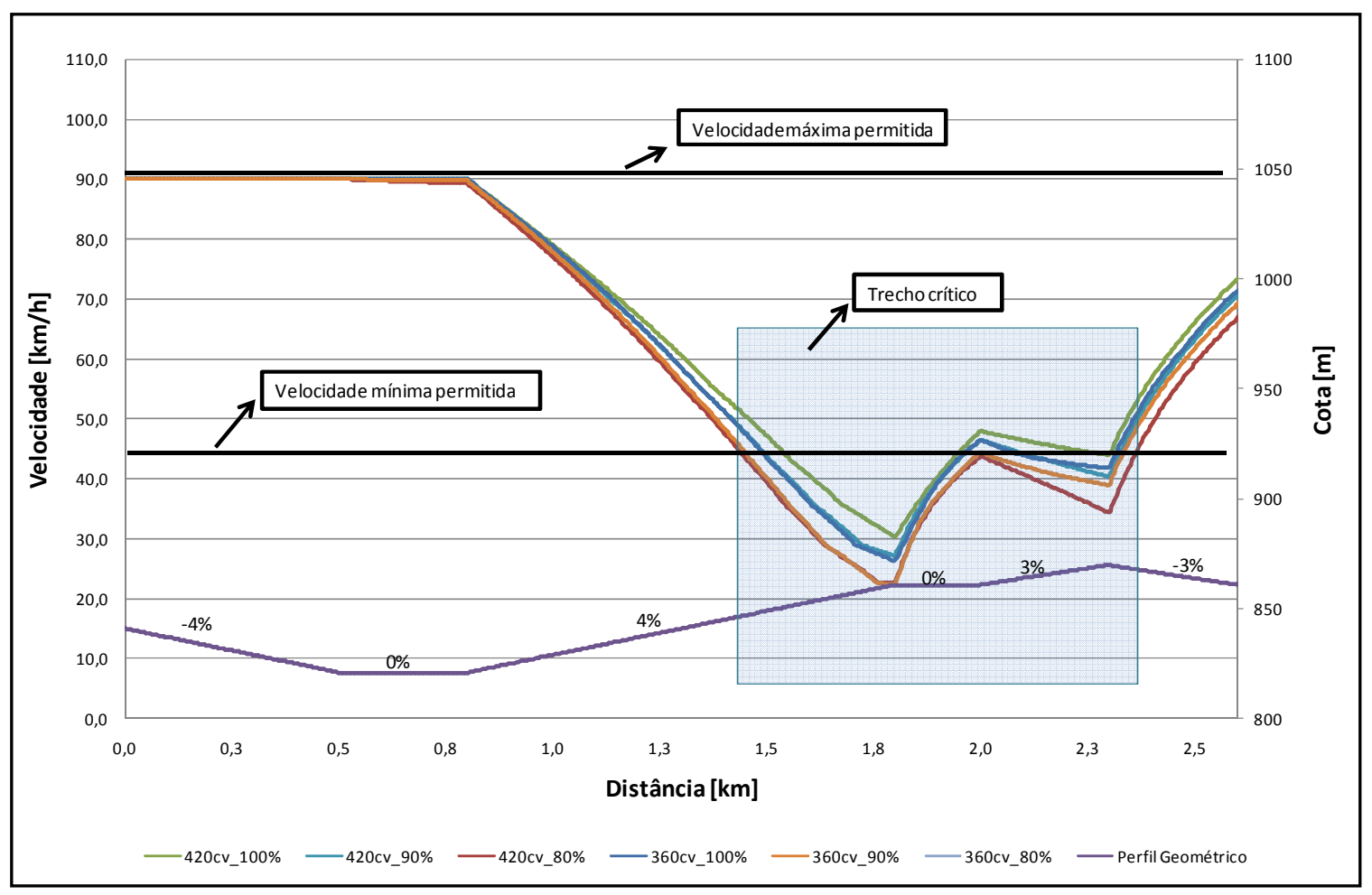

Figura 41: Pontos críticos em projeto de rodovia

Neste caso, o projetista deveria rever o perfil longitudinal ou prever dispositivos como faixas de ultrapassagem, uma vez que automóveis que utilizarão o mesmo trecho são capazes de trafegar na velocidade máxima permitida.

Realizando simulações com diferentes veículos-tipo, é possível determinar se o projeto atende satisfatoriamente os mesmos, ou ainda, determinar qual a porcentagem de veículos de carga compatíveis com cada trecho da rodovia projetada. Uma conseqüência direta é a possibilidade de estabelecer uma classificação qualitativa da compatibilidade de tráfego da rodovia com os veículos, especialmente os pesados e extra-pesados.

Outros fatores como capacidade de frenagem motora, devem também ser avaliados, tanto para o declive inicial (-4\%) como para o trecho em aclive, na hipótese de haver fluxo de veículos em ambos os sentidos.

Verificações de sobrelargura para eventuais curvas horizontais, principalmente nos acessos e dispositivos de retorno, devem ser feitas de preferência com o auxílio de curvas tractrix. Analogamente se faz necessária a verificação 
dos limiares de escorregamento e tombamento a partir das declividades da seção transversal da pista e do raio de curva horizontal.

Neste ponto, fica clara a necessidade de que, para cada trecho de rodovia, seja avaliada a compatibilidade de tráfego com caminhões e CVCs, haja vista a grande variabilidade e possibilidade de ocorrência de incompatibilidade de tráfego, tanto em trechos em tangente, como o exemplificado, como em trechos com maiores complexidades, como acessos, curvas horizontais, inclinações transversais, e restrições de gabarito.

Os conceitos apresentados neste exemplo de aplicação do estudo de compatibilidade de tráfego de veículos com o trecho de rodovia proposto podem ser estendidos a estudos mais complexos de consistência de projetos de rodovias, inclusive para rodovias já construídas, desde que levantadas suas características geométricas. 


\subsection{Outros estudos de compatibilidade}

A seção 4.1 apresentou estudos de compatibilidade de tráfego baseados no desempenho dinâmico do veículo em tração. Outros estudos de compatibilidade também são necessários tais como: a determinação da potência mínima de frenagem motora disponível, a capacidade de frenagem de emergência, os limiares tombamento e escorregamento lateral e a sobrelargura requerida em curvas de raios pequenos.

\subsubsection{Potência de Frenagem Motora}

Aplicando a formulação exposta na seção 2.2, calculamos o valor da potência de frenagem motora que uma CVC deve efetivamente possuir para dissipar a energia que o veículo adquire ao percorrer um declive longo e acentuado.

Tabela 11: Potência de frenagem motora requerida pela Resolução no 777/93

\begin{tabular}{|c|c|c|c|c|c|}
\hline $\begin{array}{c}\text { PBTC } \\
(\mathrm{t})\end{array}$ & $\begin{array}{c}\text { Potência de } \\
\text { Frenagem }(\mathrm{cv})\end{array}$ & $\begin{array}{c}\mathrm{cv} / \mathrm{t} \\
(\mathrm{min})\end{array}$ & $\begin{array}{c}\text { PBTC } \\
(\mathrm{t})\end{array}$ & $\begin{array}{c}\text { Potência de } \\
\text { Frenagem }(\mathrm{cv})\end{array}$ & $\begin{array}{c}\text { cv/t } \\
(\mathrm{min})\end{array}$ \\
\hline 5 & 27,92 & 5,58 & 55 & 337,75 & 6,14 \\
\hline 10 & 58,91 & 5,89 & 60 & 368,73 & 6,15 \\
\hline 15 & 89,89 & 5,99 & 65 & 399,72 & 6,15 \\
\hline 20 & 120,87 & 6,04 & 70 & 430,70 & 6,15 \\
\hline 25 & 151,85 & 6,07 & 75 & 461,68 & 6,16 \\
\hline 30 & 182,84 & 6,09 & 80 & 492,66 & 6,16 \\
\hline 35 & 213,82 & 6,11 & 85 & 523,65 & 6,16 \\
\hline 40 & 244,80 & 6,12 & 90 & 554,63 & 6,16 \\
\hline 45 & 275,79 & 6,13 & 95 & 585,61 & 6,16 \\
\hline 50 & 306,77 & 6,14 & 100 & 616,59 & 6,19 \\
\hline
\end{tabular}

A Tabela 11 apresenta o cálculo da potência de frenagem motora necessária para que veículos com diferentes valores de PBTC sejam capazes de percor- 
rer um declive de $-6,5 \%$, com extensão qualquer, com velocidade constante de $30 \mathrm{~km} / \mathrm{h}$, sem utilizar o sistema de freio auxiliar, exigência da norma européia ECE-13, também adotada pela regulamentação brasileira através da Resolução № 777 , de 17/12/1993.

Observa-se pelos valores da tabela, que independentemente do PBTC do veículo, o cálculo da potência de frenagem motora mínima para atender as regulamentações conduz ao valor de 6,0cv/t, ou seja, a potência de frenagem motora disponível pelo veículo, com ou sem a utilização de retarders, é da ordem de seis vezes o peso bruto total combinado do veículo.

\subsubsection{Sobrelargura}

A Figura 42 apresenta o resultado da simulação de uma CVC 11 S1 em uma conversão de $90^{\circ}$, raio curto, típica de vias urbanas.

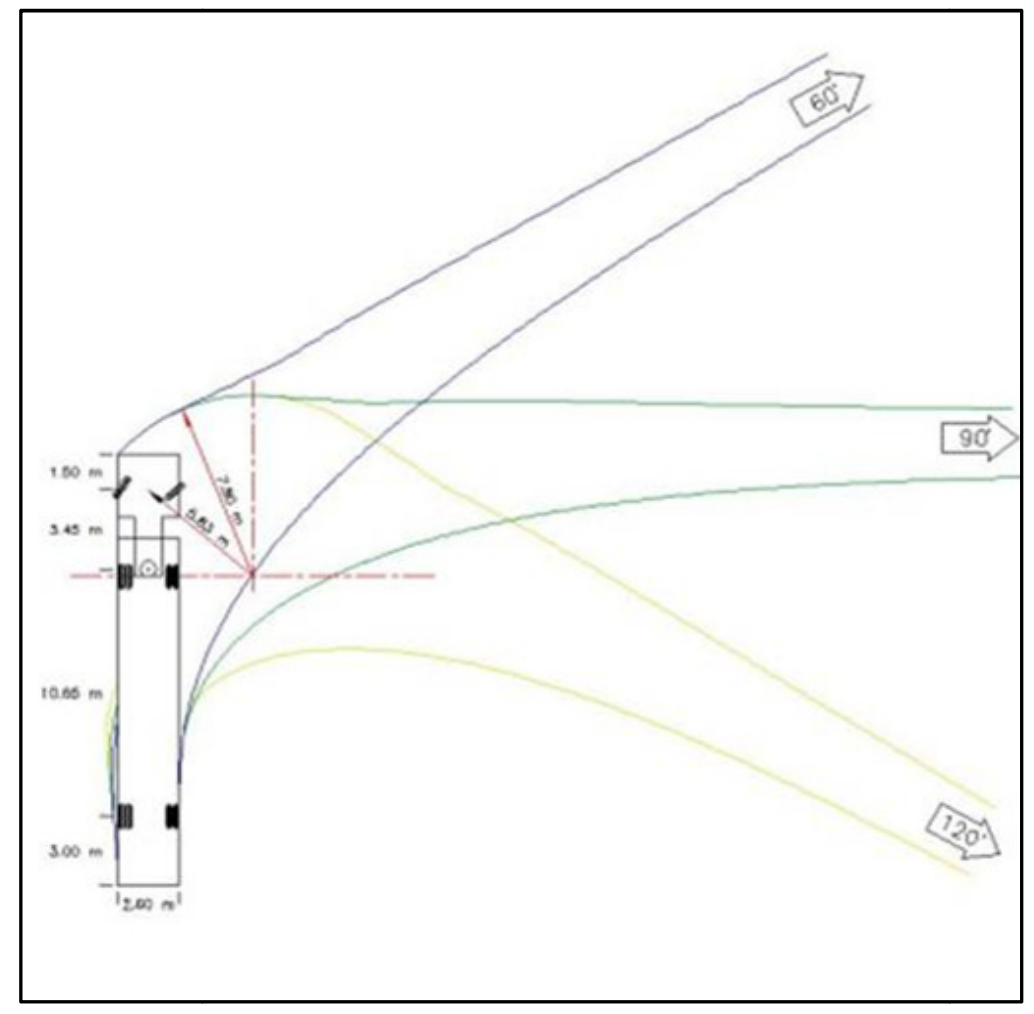

Figura 42: Exemplo de curva gerada pelo AutoTurn (Freitas, 2009) 
A partir da área necessária para a conversão é possível avaliar se os gabaritos de conversões são compatíveis com o veículo em estudo, ou ainda, se determinado projeto é compatível com os veículos que lá trafegarão.

Como a área ocupada pelos veículos está diretamente associada às suas dimensões, como distância entre eixos, balanço traseiro, bitola, etc., e alterações nestas dimensões podem atualmente ser realizadas fora das linhas de fabricação dos veículos, a adoção de um critério para certificação de tráfego como o "Círculo Europeu", apresenta-se como alternativa viável para controlar as alterações na geometria dos veículos e fixar critérios de projeto que atendam satisfatoriamente caminhões e CVCs. 


\section{CONCLUSÃO}

O Capítulo 2 abordou diversos modelos matemáticos desenvolvidos com a finalidade de prever o comportamento de caminhões em suas mais variadas situações de operação, além de discutir normas e regulamentações pertinentes a cada área de aplicação.

Com o objetivo de criar ferramentas para avaliar a compatibilidade de tráfego de veículos rodoviários de carga com trechos de rodovias, foram selecionados modelos que representam com acurácia o comportamento destes veículos e desenvolvida uma planilha eletrônica que facilita a realização de análises de compatibilidade mediante a aplicação dos modelos, implementados como rotinas de cálculo.

Os resultados gerados pelo simulador de tráfego foram avaliados frente às proposições de manuais de projeto de rodovias e dados coletados em pesquisas, concluindo-se que eles são consistentes com o nível de acurácia necessária às avaliações de compatibilidade mostradas.

No Capítulo 4 foram realizados estudos de compatibilidade hipotéticos, que mostram a aplicabilidade do método estudado, permitindo inclusive adotar critérios para conceder ou não a permissão de tráfego em vias com geometria conhecida. Complementarmente, fornecem subsídios para que órgãos regulamentadores estabeleçam critérios de gestão de operação de rodovia como:

1) Compatibilidade geométrica: sobrelargura, tombamento e escorregamento;

2) Compatibilidade de desempenho: capacidade motora, consumo de combustível, emissão de poluentes, frenagens motora e de emergência.

Ressalta-se a influência do operador, que deve ter orientação suficiente para extrair do veículo que opera o melhor desempenho, mantendo a segurança das operações. 
A ferramenta desenvolvida mostra-se válida também para operadores do setor preverem o desempenho de suas composições em operações definidas, possibilitando a identificação de pontos críticos e a adoção de medidas preventivas. Em casos específicos, pode ser utilizado para embasar tecnicamente solicitações de Autorização Especial de Trânsito.

Por simplificar a relação entre dados técnicos disponíveis dos equipamentos comerciais e os modelos teóricos até então utilizados, este trabalho amplia a possibilidade de operadores do sistema rodoviário de transportes, órgãos regulamentadores e pesquisadores agregarem valor técnico às suas decisões e estudos sobre tráfego de veículos rodoviários de carga.

Os objetivos propostos na seção 1.2 foram alcançados. O simulador SimVC proporciona a realização de simulações ágeis, de baixo custo e acessíveis a diversos setores do sistema rodoviário de transportes, fornecendo subsídios para tomada de decisões sobre a certificação de tráfego de veículos de carga.

A abordagem proposta reforça a necessidade de complementar os manuais de projetos de rodovias, para que esses contemplem o variado desempenho dos veículos que potencialmente trafegarão nas rodovias a serem construídas e orientem intervenções nos trechos de rodovias existentes com geometria incompatível com os veículos em operação. Assim, cumpre-se o objetivo secundário e complementa-se a pesquisa de Pereira Neto (2007).

Por avaliar aspectos relevantes do desempenho de veículos pesados em rodovias recomenda-se a aplicação do método apresentado a estudos de consistência de projetos de rodovias, com o objetivo de visualizar as principais deficiências destes.

É possível também avaliar a consistência geométrica de rodovias existentes através de levantamentos planialtimétricos convencionais, ou com auxílio de um aparelho GPS, e posteriormente verificar a distribuição dos perfis de velocidades de veículos utilizando para isso o simulador SimVC. 
Além dos objetivos propostos, este trabalho evidencia a necessidade de estudos mais aprofundados de compatibilidade de tráfego entre caminhões e CVCs com trechos de rodovias, sendo as sugestões para novos trabalhos apresentadas na seção 5.1 . 


\subsection{Sugestões para novos trabalhos}

O estudo da interação entre caminhões ou CVCs e rodovias é amplo e tem sido alvo de muitas pesquisas, cujos objetivos são os mais diversos possíveis. Fabricantes e operadores buscam veículos que melhor se adaptem com as rodovias e cargas das regiões em que operam, projetistas procuram por critérios eficientes e eficazes para orientarem seus projetos e órgãos regulamentadores critérios técnicos para fiscalizar e garantir operações de transporte de carga, estimulando o tráfego sustentável e seguro.

Este trabalho contribui para o entendimento das relações entre veículos e rodovias, além de abrir possibilidades para aprofundamento de estudos de compatibilidade de tráfego, como:

1. Pesquisas sobre perfis de condutores e sua influência sobre os projetos de rodovias, ou até mesmo a exigência de condutores especializados para a certificação de tráfego de caminhões e CVCs;

2. Calibração do simulador desenvolvido para condições específicas: neste trabalho foi realizada a verificação do simulador, que mostrou resultados condizentes com os observados em campo e propostos pelos manuais de projeto. Fica aberta também a possibilidade de calibrar o simulador para trechos de rodovias e veículos específicos;

3. Implementação de modelos mais elaborados: modelos mais sofisticados para melhor representar o comportamento de veículos de carga, permitindo agregar maior valor técnico aos trabalhos de certificação de tráfego, podem ser realizados no sentido de complementar o simulador SimVC, especialmente nas áreas de estabilidade e controle e consumo de combustível;

4. Adaptação do modelo implementado para utilização do mapa de desempenho dos motores das unidades tratoras, que considerariam a potência efetivamente fornecida para taxas de utilização de potência intermediárias. Outra vantagem seria a também utilização do mapa de consumo específico dos mo- 
tores, para melhoria da precisão dos resultados de consumo de combustível e emissão de poluentes;

5. Estudos do benefício social de uma rodovia, mediante avaliação do consumo de combustível, e conseqüentemente impacto ambiental, de diferentes alternativas de projeto;

6. Alimentar macro-simulações e assim analisar benefícios de soluções ITS, construções de estradas e rodovias;

7. Influência do modelo de aceleração do condutor sobre o consumo de combustível: como visto no Capítulo 3, é grande a importância do condutor sobre o desempenho do veículo. Por estar diretamente associada à potência utilizada pelo motor, o consumo de combustível também varia de acordo com o condutor do veículo e porcentagem da potência disponível utilizada. Assim, um estudo comparativo da variação do consumo de combustível entre diferentes perfis de condutores mostra-se necessário;

8. Desenvolvimento de método para análise da consistência de projetos de rodovias e verificação da consistência geométrica de rodovias existentes. 


\section{REFERÊNCIAS BIBLIOGRÁFICAS}

AASHTO (2004) A policy on geometric design of highways and streets. 5 ed. Washington: American Association of State Highway and Transportation Officials. 896p. ISBN: 1-56051-263-6.

ABNT - Associação Brasileira de Normas Técnicas (1990). NBR 10966 Desempenho de sistemas de freio para veículos rodoviários. Publicada em 01/03/1990.

ABNT - Associação Brasileira de Normas Técnicas (1999). NBR 10967 -

Sistema de freio para veículos rodoviários - Ensaio de desempenho. Publicada em 30/08/1999.

AHN, K. (1998) Microscopic fuel consumption and emission modeling. 131p. Dissertação (Mestrado), Faculty of the Virginia Polytechnic Institute and State University, Blacksburg, Virginia, 1998.

AKCELIK, R. (1989) Efficiency and drag in the power-based model of fuel consumption. Transportation Research 23B, 376-385.

ALGERS, S.; BERNAUER, E.; BOERO M.; BREHERET L.; DI TARANTO, C.; DOUGHERTY, D.; FOX K.; GABARD, J.F. (1997) Review of micro-simulation models. Report of the SMARTEST project - deliverable 3.

ANDRÉ, M; HAMMARSTRÖM, U. (2000) Driving speeds in Europe for pollutant emissions estimation. Transportation Research Part D: Transport and Environment, v. 5., issue 5, Setembro, p. 321-335.

ARCHILLA; A.R. (1996) Truck performance on argentinean highways. TRB 1555, ISSN 0361-1981. Argentina. p.114-123.

AUTOTURN (2003) Computer Aid Design. Version 4.0. TRANSOFT Solutions Inc. 
AUSTROADS (2002) Rural Road Design: a guide to the geometric design of rural roads. 6⿳亠丷厂 Edição. Sydney. Association of Australian and New Zeland Road Transport and Traffic Authorities. 126p.

BARRETO, M.A.Z. (2005) Dinâmica longitudinal : efeitos da geometria de suspensão nas mudanças de atitude da massa suspensa e os esforços nos elementos da suspensão. 111p. Dissertação (Mestrado) - Escola de Engenharia de São Carlos, Universidade de São Paulo, São Carlos.

BARTH, M.; AN, F.; YOUNGLOVE, T.; SCORA, G.; LEVINE, C.; ROSS, M., and WENZEL, T. (2000) Comprehensive modal emission model (CMEM), version 2.0 user's guide.

BARTHOLOMEU, D.B. (2006) Quantificação dos impactos econômicos e ambientais correntes do estado de conservação das rodovias brasileiras. 165p. Tese (Doutorado), Escola Superior de Agricultura "Luiz de Queiroz", Universidade de São Paulo, Piracicaba, 2006.

BARTON, R.A.; MORRAL, J. (1998) Study of long combination vehicles on twolane highways. Transportation Research Record 1613, Transportation Research Board, p. 43-49. ISBN: 0309064589.

BRASIL (1993) Conselho Nacional de Trânsito. Dispõe sobre os procedimentos para avaliação dos sistemas de freios de veículos. Resolução № $\mathbf{7 7 7}$, de 17/12/1993. Brasília.

BRASIL (1994) Conselho Nacional de Trânsito. Requisitos de segurança necessários à circulação de combinações de veículos. Resolução № 631 DE 25/04/1984. Brasília.

BRASIL (2006a) Conselho Nacional de Trânsito. Estabelece os limites de peso e dimensões para veículos que transitem por vias terrestres e dá outras providências. Resolução no 210, 13/11/2006. Brasília. 
BRASIL (2006b) Conselho Nacional de Trânsito. Requisitos necessários à circulação de Combinações de Veículos de Carga - CVC, a que se referem os arts. 97, 99 e 314 do Código de Trânsito Brasileiro-CTB. Resolução no 211, 13/11/2006. Brasília.

BRASIL (2006c) Conselho Nacional de Trânsito. Fixa requisitos para a circulação de veículos transportadores de contêineres. Resolução no 213, 13/11/2006. Brasília.

BRASIL (2007) Conselho Nacional de Trânsito. Altera o $\S 2^{\circ}$, do art. $2^{\circ}$ da Resolução ํㅡ 211, de 13 de novembro de 2006, do CONTRAN. Resolução no 256, de 30/11/2007. Brasília.

BRASIL (2009) Departamento Nacional de Trânsito. Pesquisa Frota Nacional 2006. Disponível em: http://www.denatran.gov.br/frota.htm. Acessado em: 30/05/2009.

CANALE, A.C. (1989) Automobilistica: dinâmica e desempenho. 125p. Editora Érica. São Paulo

CANALE, A.C. (1991) Estudo do desempenho de autoveículos rodoviários considerando o passeio do centro de gravidade e restrições impostas pelo binômio pneumático x pavimento. São Carlos, 1991. 290p. Tese (doutorado) Escola de Engenharia de São Carlos, Universidade de São Paulo.

CANALE, A.C. (1993) Estudo teórico do desempenho da frenagem de um autoveículo rodoviário utilizando um sistema semi-automático. In: Sae Technical Paper Series 931620 São Paulo : Sae Brasil, p.1-10, 1993.

CANALE, A. C. (2007) Manual do condutor de veículos comerciais. 2007. 106p. 
CANALE, A.C.; FERNANDES, D.L.G.; PERSEGUIM, O.T. (1995) Obtenção das forças que ocorrem nos eixos e na suspensão de um veículo combinado articulado. In: Anais Rio de Janeiro : Abcm, 1995.

CANALE, A.C.; NAVARRO,H.A.; D'ELBOUX, J.E.; SARAIVA, J.R.; VALTAS, N.B. (1997) Consumo de combustível de veículos comerciais em velocidade constante. ABEA 1997, São Paulo, Anais, p.83-89.

CANALE, A.C.; FERREIRA, H.T. (2005) Estudo de "ride" de um caminhão de dois eixos utilizando o programa MATLAB-SIMULINK. In: SAE Technical Paper Series, 2005-01-4062 São Paulo : SAE Brasil, 2005, p.1-10.

CANALE, A. C. ; HORTA GUTIÉRREZ, J. C. ; WIDMER, J. A. ; BOTELHO, J. H.; POLITO, R. ; KISS, V. (2005) A importância de um plano de revisão e complementação das normas e regulamentações de frenagem de veículos rodoviários de carga no Brasil. SAE Brasil, Caxias do Sul, 2005. p. 37-42..

CANALE, A.C.; GUTIÉRREZ, HORTA, J.C. (2005) Estudo do desempenho da frenagem e do controle da velocidade de descida em declive longo e acentuado no trecho da Serra do Mar da Rodovia dos Imigrantes de veículos comerciais representativos da frota nacional. v.1. 405p.

CANALE, A.C.; HORTA GUTIÉRREZ, J.C.; ORTEGA, F. (2006) Viabilidade da liberação do tráfego de veículos comerciais na pista descendente da rodovia dos imigrantes. SAE Technical Paper Series, 2006-01-2752 São Paulo: SAE Brasil, 2006, p.1-12.

CNT (2009) Boletim Estatístico CNT - 2009. Confederação Nacional do Transporte. Pesquisa Rodoviária 2006. 155p. Disponível em: http://sistemacnt.cnt.org.br. Acessado em 30/05/2009.

COSTA, Argemiro L.A. (2007) Caracterização do comportamento vibracional do sistema pneu-suspensão e sua correlação com o desgaste irregular verificado em pneus dianteiros de veículos comerciais. 170p. + anexos. 
Tese (Doutorado) - Escola de Engenharia de São Carlos, Universidade de São Paulo, São Carlos.

COSTA, Ely E.S. (1997) Análise da compatibilidade do gabarito de caminhões com a geometria das interseções urbanas numa cidade de médio porte. 91p. + apêndice. Dissertação (Mestrado) - Escola de Engenharia de São Carlos, Universidade de São Paulo, São Carlos.

CROWTHER, B.C. (2001) A comparison of CORSIM and INTEGRATION for the modelling of stationary bottlenecks. 132f. Tese (Mestrado) - Virginia Polytechnic Institute and State University, Blacksburg, EUA.

CUNHA, A.L.B.N. (2007) Avaliação do impacto da medida de desempenho no equivalente veicular de caminhões. 2007. 147 p. Dissertação (Mestrado) Escola de Engenharia de São Carlos, Universidade de São Paulo, São Carlos.

DEBS, M.K.E.; MALITE, M.; TAKEYA, T.; MUNAIAR NETP, J.; HANAI, J.B.; OLIVEIRA, P.E. (2004) Análise das conseqüências do tráfego de combinações de veículos de carga (CVCs) sobre as pontes da rede viária sob jurisdição do DER-SP. Revista Minerva São Carlos, v. 1, n. 1, p. 27-35.

DEMARCHI, S.H. (2000) Influência dos veículos pesados na capacidade e nível de serviço de rodovias de pista dupla. 166 p. Tese (Doutorado em Engenharia de Transportes) - Escola de Engenharia de São Carlos, Universidade de São Paulo, São Carlos.

DEMARCHI, S.H.; KLEIN, N.S. (2005) Análise comparativa dos modelos de desempenho incorporados ao simulador Truper. In: XIX Congresso de Pesquisa e Ensino em Transportes, Recife, PE. Anais do XIX ANPET. Rio de Janeiro : Editora Universitária, 2005. v.1, p. 904-916.

DEMARCHI, S.H.; MELO, R.A.; SETTI, J.R.A. (2000) Validação de um modelo de desempenho de caminhões em rampas ascendentes. ANPET 2000. Gramado-RS. Volume 1. 
DNER (1999) Manual de Projeto Geométrico de Rodovias Rurais. Rio de Janeiro: IPR. $195 \mathrm{p}$.

DNIT (2007) SIAET - Sistema de Gerenciamento de Autorização Especial de Trânsito. Disponível em: http://www1.dnit.gov.br/aplweb/sis_siaet/ . Acessado em: 26/11/2008.

DONALDSON, G.A. (1986) Safety of large trucks and the geometric design of two-lane, two-way roads. Transportation Research Record 1052, Transportation Research Board, Nacional Research Council. ISBN 0-309-039681. p.10-14.

EPA (2007) MOBILE6 Vehicle Emission Modeling Software. United States Enviromental Protect Agency. Disponível em : http://www.epa.gov/otaq/m6.htm. Consultado em: 26/11/2007.

FABBRI, G.T.P.; FERNANDES JÚNIOR, J.L.; WIDMER, J.A.; SÓRIA, M.H.A. (1990) Análise de composições rodoviárias quanto a fatores de destruição de pavimentos. In: REUNIÃO ANUAL DE PAVIMENTAÇÃO DA ABPV, 24, 1990, Belém. Anais... Belém: ABPV. p.147-169.

FANCHER, P.S.; MATHEW, A. (1987) A vehicle dynamics handbook for single-unit and articulated heavy trucks. Federal Highway Administration. (Relatório № DOT HS 807, UMTRI, MI, EUA).

FERNANDES, D.L.G. (1994) Estudo da freagem de autoveículos rodoviários articulados pesados. 153 p. Dissertação (Mestrado) - Escola de Engenharia de São Carlos, Universidade de São Paulo, São Carlos, 1994.

FERNANDES, D.L.G. (2000) Análise de veículos rodoviários articulados pesados na freagem através da técnica dos mapas de desempenho. 194p. Tese (Doutorado) - Escola de Engenharia de São Carlos, Universidade de São Paulo, São Carlos, 2000. 
FERNANDES JÚNIOR, J.L. (1994) Investigação dos efeitos das solicitações do tráfego sobre o desempenho de pavimentos. 313 p. Tese (Doutorado) Escola de Engenharia de São Carlos, Universidade de São Paulo, São Carlos, 1994.

FERREIRA, L.M.; WIDMER, J.A.; DEBS, M.K.E. (2007) Proposta de limites para o peso de caminhões em pontes de concreto. In: CONGRESSO BRASILEIRO DE RODOVIAS E CONCESSÕES, Campinas. Anais...

FREITAS, G.C. (2009) Método de Avaliação da Compatibilidade de Tráfego de Caminhões com a Geometria das Vias Urbanas. Relatório de Iniciação Cientíca. Engenharia de Transportes, EESC/USP.

FITCH, J.W. (1994) Motor truck engineering handbook. $4^{\text {th }}$ Edition, Society of Automotive Engineers, Warrendale, Pennsylvania, EUA. ISBN: 1560913789.

FREY, H.C.; UNAL A., CHEN J.; LI S.; XUAN C. (2002) Methodology for developing modal emission rates for EPA's multi-scale motor vehicle and equipment emission estimation system, desenvolvido por North Carolina State University para o Office of Transportation and Air Quality, U.S.

Environmental Protection Agency, August 31, 2002.

GILLESPIE, T.D. (1992) Fundamentals of vehicle dynamics. Warrendale: SAE. ISBN Number: 978-1-56091-199-9. 519p.

HEALD, K.L. (1986) Use of the WHI offtracking formula. TRB, TRR1052.

HORTA-GUTIÉRREZ, J.C. (1999) Estudo da estabilidade direcional de veículos combinados tipo cavalo semi-reboque. 205p. + apêndice. Tese (Doutorado) - Escola de Engenharia de São Carlos, Universidade São Paulo, São Carlos. 
INMETRO (1989) Portaria no 01, de 10 de abril de 1989. Nacional de Metrologia, Normalização e Qualidade Industrial. Disponível em:

http://www.inmetro.gov.br. Acessado em 20/11/2008.

JACONDINO, G.B. (2005) Quantificação das emissões veiculares através do uso de simuladores de tráfego. 133p. Dissertação (Mestrado), Universidade Federal do Rio Grande do Sul, Porto Alegre, 2005.

KABBACH JÚNIOR, F.I. (1985) Reavaliação das distâncias de visibilidade de parada e dos comprimentos de curvas verticais requeridos para projetos de vias rurais e urbanas. 100p. Dissertação (Mestrado) - Escola Politécnica, Universidade São Paulo, São Paulo.

LILL, L.A. (1986) Geometric design for large trucks-an overview of the Issues from the perspective of the American trucking associations. Transportation Research Record 1052, Transportation Research Board, Nacional Research Council. ISBN 0-309-03968-1. p.6-9.

LOTTI, C.P. (2002) Método de sistematização e levantamento de dados para o estudo da relação de acidentes com o alinhamento em planta e perfil de uma rodovia. Tese (Doutorado em Engenharia de Transportes) - Escola de Engenharia de São Carlos, Universidade de São Paulo, São Carlos.

LUCAS, M.J. (2004a) Faixas adicionais para rodovias com longos declives considerando o aspecto térmico do sistema de freios. 136 p. Dissertação (Mestrado em Engenharia de Transportes) - Escola de Engenharia de São Carlos, Universidade de São Paulo, São Carlos, 2004.

LUCAS, M.J.; WIDMER, J.A. (2004b) Características de frenagem da frota brasileira de caminhões e CVCs e sua Influência sobre a segurança e a capacidade das vias em declives longos. In: XVIII ANPET - Congresso de Pesquisa e Ensino em Transportes, 2004, Florianópolis. Panorama Nacional da Pesquisa em Transportes 2004. v.1. p. 599-610. 
LUCIC, I. (2001) Truck modeling along grade sections. 2001. 229p. Tese (Mestrado), Virginia Polytechnic Institute and State University, Blacksburg, Virginia.

MANNERING, F.L. (1998) Principles of highway engineering and traffic analysis. 340p. 2ª Edição. Nova York.

MELO, Ricardo A. (2002) Faixas adicionais para aclives de rodovias brasileiras. 2002. 178p. Tese (Doutorado em Engenharia de Transportes) Escola de Engenharia de São Carlos, Universidade de São Paulo, São Carlos.

MELO, Rubem P. (2004) Avaliação da estabilidade lateral em conjuntos de veículos de carga. 112p. Dissertação (Mestrado) - Pontifícia Universidade Católica do Paraná, Curitiba.

MILLIKEN, W.F. (1995) Race car vehicle dynamics. Warrendale: Society of Automotive Engineers - SAE. 890p.

NAGL, P. (2007) Longer combination vehicles (LCV) for Asia and the Pacific region: some economic implications. UNESCAP Working Paper, United Nations, Economic and Social Commission for Asia and the Pacific. 3p.

PEREIRA NETO, W.A. (2007) Análise de fatores intervenientes nas características dimensionais de segmentos rodoviários sob a óptica da compatibilidade veículo-via. 190 p. Tese (Doutorado) - Escola de Engenharia de São Carlos, Universidade de São Paulo, São Carlos.

PERSEGUIM, O.T. (2005) Dinâmica veicular relativa ao ride de veículos e métricas para sua avaliação. 221P. Tese (Doutorado) - Escola de Engenharia de São Carlos, Universidade de São Paulo, São Carlos.

POLITO, R.F. (2005) Estudo do desempenho na frenagem de um bi-trem com suspensão em "tandem" e com ABS. 116p. Dissertação (Mestrado) Escola de Engenharia de São Carlos, Universidade de São Paulo, São Carlos. 
POST, K.; KENT, J.H.; TOMLIN, J.; CARRUTHERS, N. (1984) Fuel consumption and emission modeling by power demand and a comparison with other model. Transportation Research 18A, 191-213.

RAKHA, H; YU, B. (2005) Impact of tire and aerodynamic aids on truck performance along upgrade sections. Transportation Research Board $84^{\text {th }}$, Washington D.C., CD-ROM [Paper 05-0899].

RAKHA, H.; AHN, K.; TRANI, A. (2004) The VT-Micro framework for modeling of hot stabilized light duty vehicle and truck emissions. Transportation Research, Part D: Transport \& Environment, v 9(1), Janeiro, p. 49-74.

RAKHA, H.; LUCIC, I. (2002) Variable Power Vehicle Dynamics Model for Estimating Maximum Truck Acceleration Levels. Journal of Transportation Engineering , v 128(5), Set/Out, p. 412-419.

RAKHA, H.; LUCIC, I.; DEMARCHI S.; SETTI J.; VAN AERDE M. (2001) Vehicle dynamics model for predicting maximum truck accelerations. Journal of Transportation Engineering, v 127(5), Outubro, p. 418-425.

RUSSO, M.R.A. (1995) Impacto de manobras de veículos combinados sobre a geometria horizontal de interseções rodoviárias. 131p. Tese (Doutorado) Escola de Engenharia de São Carlos, Universidade de São Paulo, São Carlos.

SAE (1976) SAE J670e - Vehicle dynamics terminology - issued by the Vehicle Dynamics Committee, July 1952. Revised ed. Warrendale, USA.

SAE (1996) Commercial truck and bus SAE recommended procedure for vehicle performance prediction and charting: Procedure J2188. Warrendale: Society of Automotive Engineers.

SAE Standards. Title: Truck Ability Prediction Procedure (Cancelled Feb 1997, Superseded by J2188) 
SAE Standards (1997) Commercial Truck and Bus SAE Recommended Procedure for Vehicle Performance Prediction and Charting Issuing Committee: Truck And Bus Engine And Vehicle Performance Subcommittee

SILVEIRA,G.L.; SOUZA,A.P.; SANTOS,H.N. ; MACHADO,C.C ; FERNANDES, D.C.M.; FERNANDES, D.C.M. (2004) Avaliação de parâmetros de consumo de combustível do Tritrem no transporte de madeira.. Revista Árvore, Viçosa-MG, v. 28, n. 1, p. 99-106, 2004.

SOLOMON, D. (1964) Accidents on main rural highways related to speed, driver and vehicle. Bureau of Public Roads, U.S. Department of Commerce.

SOUZA, L.P. (2007) A infeficácia do parâmetro CMT - Capacidade Máxima de Tração como medida de desempenho de caminhões e CVCs em aclives e declives longos. 5ํㅡㄹ Congresso Brasileiro de Rodovias e Concessões, 2007, Campinas. ABCR - Associação Brasileira de Concessionárias de Rodovias.

TAC (1999) Geometric Design Guide for Canadian Roads. Ottawa: Transportation Association of Canada. ISBN: 1-55187-131-9.

VIANNA, E.P. (2006) Estudo da influência do levantamento de eixos em veículos comerciais no desempenho na frenagem e na estabilidade direcional. 136p. Tese (Doutorado) - Escola de Engenharia de São Carlos, Universidade de São Paulo, São Carlos.

WATANADA, T (1987) The highway design and maintenance standard model. University Baltimore.

WIDMER, J.A. (1999) O desempenho de caminhões em aclives e a segurança viária. VIII Congresso e Exposição Internacionais da Tecnologia da Mobilidade, 1999, São Paulo. SAE Brasil 1999, trabalhos publicados em separatas.

WIDMER, J.A. (2002) Compatibilidade de tráfego de bi-trens de 25m com a infraestrutura viária brasileira. In: Anais do 2 International Suspension 
Colloquium e 1 Colloquium de Implementos Rodoviários da SAE-Brasil Regional Caxias do Sul. Caxias do Sul : SAE-BRASIL, 2002. v.1. p. 587-597.

WIDMER, J.A. (2008) A proposal of an international vehicle designation structure for cargo combination vehicles. R, J. A. In: 10th HVTT 10th Symposium of Heavy Vehicle Transport Technology, 2008, Paris. Proccedings of the 10th Symposium of Heavy Vehicle Transport Technology. Paris : Laboratoire Central de Ponts et Chaussées LCPC.

WILLEY, W.E. (1949) Survey of Uphill Speeds of Trucks on Mountain Grades. Highway Research Board Proceeding, v. 29, p.304-310. Washington.

WINKLER, C.B. (2000) Rollover of heavy commercial vehicles. Umtri Research Review, University of Michigan Transportation Research Institute, Out/Dec 2000, v.31, n. $4,23 p$.

YU, Bin. (2005) Modeling truck motion along grade sections. 139p.

Dissertação (Mestrado), Virginia Polytechnic Institute and State University 2005, Blacksburg, Virginia.

YU, Lie; QIAO, F.; SOLTANI, F. (2005) Testing and modeling of truck emissions while idling. 68 p. Research Report, Report SWUTC/06/167650-1, Southwest Region University Transportation Center, Houston, Texas, 2006. 


\section{ANEXO A - Lista de variáveis do simulador}

Este anexo apresenta as variáveis utilizadas no simulador SimVC, suas unidades e o nome atribuído à mesma no algoritmo.

\section{Tabela 12: Lista de variáveis do simulador}

\begin{tabular}{|c|c|c|}
\hline NOME & UNIDADE & VARIÁVEL \\
\hline Velocidade & $\mathrm{Km} / \mathrm{h}$ & Vel \\
\hline Aceleração & $\mathrm{m} / \mathrm{s} 2$ & Acel \\
\hline Peso Bruto Total Combinado & $\mathrm{t}$ & PBTC \\
\hline Tempo de reação & $\mathrm{s}$ & $\operatorname{Tr}$ \\
\hline Distância de visibilidade e parada & $\mathrm{m}$ & Dvp \\
\hline Rotação do Motor & rpm & Rot \\
\hline Potência Instantânea do motor & kW & Pot \\
\hline Eficiência da Transmissão & $\%$ & EficT \\
\hline Número de eixos & (sem unidade) & NumE \\
\hline Coeficiente de atrito estático & (sem unidade) & CoefAe \\
\hline coeficiente estático de atrito pneu-pavimento & $\mathrm{m}$ & Mi \\
\hline $\begin{array}{l}\text { Coeficiente que inclui a densidade do ar ao nível do mar e } \\
\text { fatores de conversão de unidades }\end{array}$ & $\mathrm{C}_{1}$ & $\mathrm{C} 1$ \\
\hline $\begin{array}{l}\text { Constante que reflete o efeito da deformação do pneu- } \\
\text { mático e da via }\end{array}$ & $\mathrm{C} 2$ & $\mathrm{C} 2$ \\
\hline $\begin{array}{l}\text { Constante que reflete o efeito de outros fatores na resis- } \\
\text { tência ao rolamento }\end{array}$ & $\mathrm{C} 3$ & C3 \\
\hline Coeficiente de penetração aerodinâmica & $\mathrm{Ca}$ & $\mathrm{Ca}$ \\
\hline Coeficiente de resistência de rolamento & $\mathrm{C}_{\mathrm{r}}$ & $\mathrm{Cr}$ \\
\hline Coeficiente de atrito aerodinâmico & $C_{d}$ & $C_{d}$ \\
\hline Coeficiente de eficiência da transmissão & $\mathrm{H}$ & Eta \\
\hline Coeficiente de altitude & $c_{h}$ & $\mathrm{Ch}$ \\
\hline Peso do veículo & $\mathrm{kN}$ & G \\
\hline Declividade da rampa & $\mathrm{m} / \mathrm{m}$ & $\mathrm{i}$ \\
\hline Área frontal do veículo & $\mathrm{m}^{2}$ & Af \\
\hline Peso do tambor ou disco (40 a $90 \mathrm{~kg}$ ) & $\mathrm{kg}$ & Wdr \\
\hline
\end{tabular}




\section{ANEXO B - Algoritmos das macros}

Este anexo apresenta os dois algoritmos desenvolvidos, o "Algoritmo de Tração" e o de "Cálculos Estáticos".

\section{1) Algoritmo de Tração}

O principal algoritmo desenvolvido é o modelo de tração, que permite estimar o perfil de velocidade do veículo ao longo de um trecho de rodovia. Complementarmente fornece rotação, potência, aceleração, força e resistências ao movimento no percurso.

A Figura 43 apresenta o fluxograma do algoritmo.

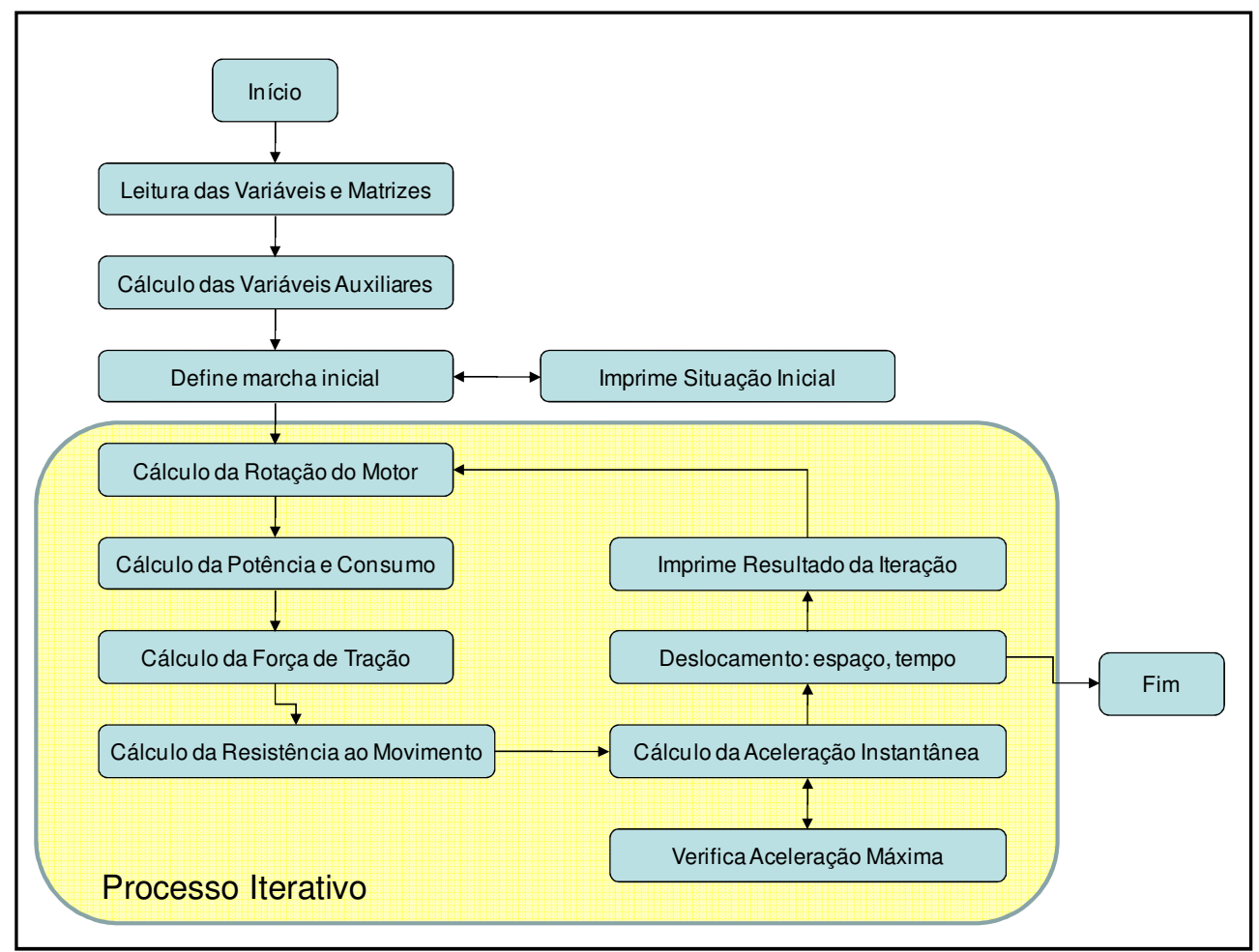

Figura 43: Fluxograma do algoritmo de tração

Inicialmente, o algoritmo limpa os dados de simulações anteriores e define o tempo inicial da simulação como "zero". 


\section{Em seguida é realizada a leitura das variáveis.}

TempoAcum $=0$

Vel = Range("C3").Value

Condutor = Range("C7").Value

Plotar = Range("C8").Value / 1000

Gd = Worksheets("ENTRADA").Range("H52").Value

Diam = Worksheets("ENTRADA").Range("H23").Value

PBTC $=$ Worksheets("ENTRADA").Range("H11").Value * 1000

Efic $=$ Worksheets("ENTRADA").Range("H37").Value

VelLimite = Worksheets("Simulador").Range("C6").Value
'Define o tempo acumulado inicial [min]

'Lê a velocidade inicial $[\mathrm{km} / \mathrm{h}]$

'Lê a porcentagem da potência do condutor

'Lê o intervalo para plotagem dos dados

'Lê a redução do diferencial

'Lê o diâmetro dinâmico do pneumático [m]

'Lê a velocidade limite definida pelo usuário

\section{'Lê a matriz da caixa de mudancas diretamente no banco de dados}

$\mathrm{i}=$ Worksheets("ENTRADA").Range("H39")

m = Worksheets("ENTRADA").Range("H43")

With Worksheets("MCMU")

Set MatrizGt $=$. Range $(. \operatorname{Cells}(\mathrm{i}, 3),$. Cells $(\mathrm{i}, \mathrm{m}+2))$

End With

\section{'Lê a matriz motor diretamente do banco de dados}

Dim MatrizMotor(21, 3) As Single

Linha $=$ Worksheets("ENTRADA").Range("H29")

'Linha da caixa de mudanças em MCMU

'Lê o número de marchas

\section{'Lê as reduções}

NRot $=$ Worksheets("MMOT").Cells(Linha, 51)

For $\mathrm{i}=1$ To NRot

MatrizMotor(i, 1) = Worksheets("MMOT").Cells(1, i + 8)

'Lê a rotação

MatrizMotor(i, 2) = Worksheets("MMOT").Cells(Linha, i + 8)

'Lê a Potencia

MatrizMotor(i, 3) = Worksheets("MMOT").Cells(Linha, i + 29)

'Lê o consumo

Next i

\section{'Lê a rodovia escolhida e define a matriz de trechos diretamente do banco de dados}

$\mathrm{i}=$ Worksheets("ENTRADA").Range("H54")

$\mathrm{j}=$ Worksheets("MROD").Cells(3, i).End(xlDown).Row

With Worksheets("MROD")

Set MatrizTre $=. \operatorname{Range}(. \operatorname{Cells}(3, \mathrm{i}),$. Cells $(\mathrm{j}, \mathrm{i}+1))$

End With
'Coluna da Rodovia escolhida

'Define a linha final da matriz

'Define a matriz de trechos 
Após a leitura das variáveis são realizados os cálculos de variáveis auxiliares, definindo inclusive a marcha para iniciar a simulação.

\section{'Define a Rotação Máxima}

RotMax = MatrizMotor $(1,1)$

For $\mathrm{i}=1$ To NRot -1

If MatrizMotor $(i+1,1)>$ MatrizMotor(i, 1) Then

$\operatorname{RotMax}=$ MatrizMotor $(\mathrm{i}+1,1)$

End If

Next i

\section{'Definir a Rotação Mínima}

RotMin $=1000+$ Worksheets("Simulador").Range("C03")

RotMax = RotMax - Worksheets("Simulador").Range("C04")

\section{' Cálculo de Constantes da Simulação (setup para o simulador)}

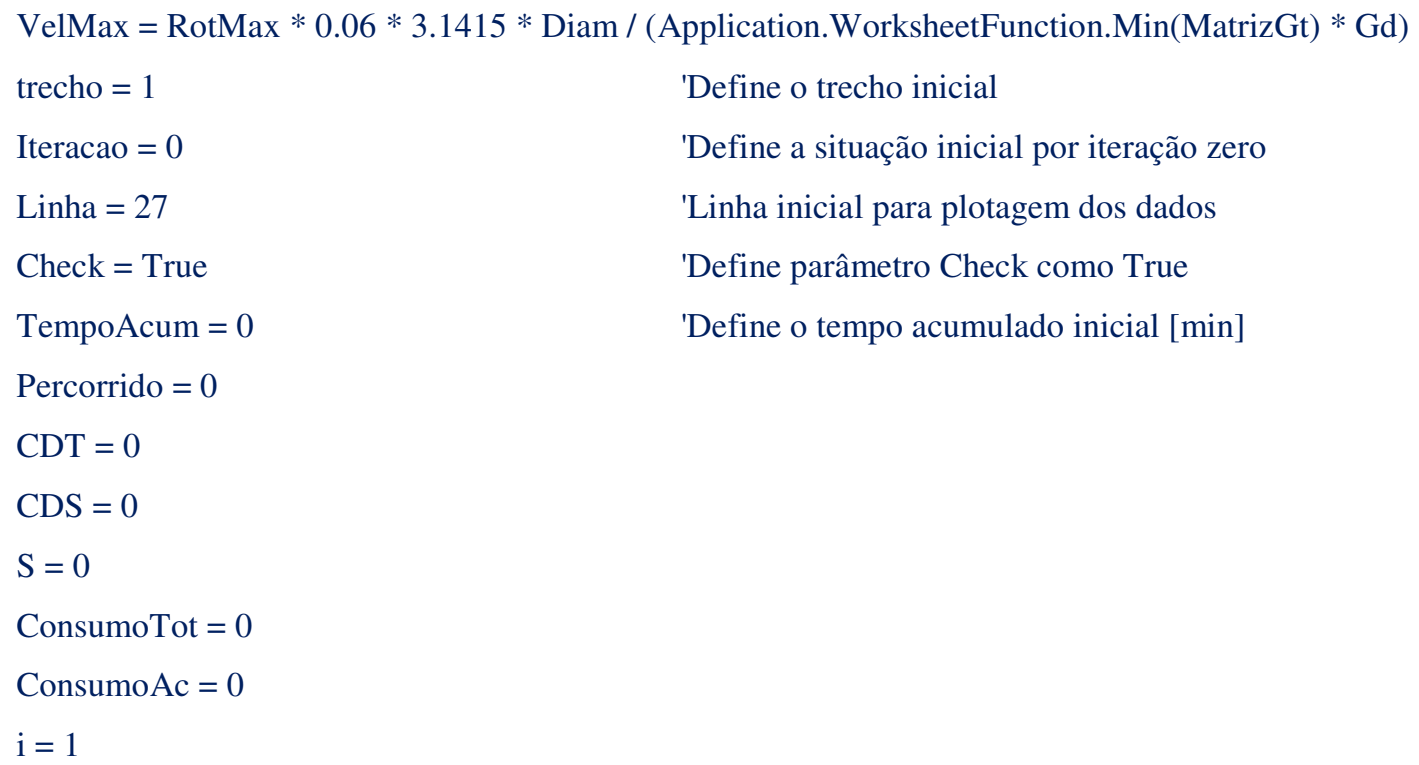

\section{'Definição da marcha para iniciar o trecho}

$\mathrm{Gt}=$ Application.WorksheetFunction.Index (MatrizGt, 1)

VelMin $=\operatorname{RotMin} * 0.06 * 3.1415 * \operatorname{Diam} /(\mathrm{Gt} * \mathrm{Gd})$

If $\mathrm{Vel}<$ VelMin Then

Vel $=$ VelMin

$\mathrm{CDT}=2 / 3600$
'Verifica se a velocidade inicial é menor 'que a velocidade mínima

'Incremento de dois segundos para atingir VelMin

MsgBox("Velocidade mínima é " \& Round(VelMin, 2))

End If

$\mathrm{Gt}=((\operatorname{RotMax}+\operatorname{RotMin}) / 2) * 0.06 * 3.1415 *$ Diam $/($ Vel $* \mathrm{Gd}) \quad$ 'Define a marcha inicial aproximada 
marcha

Gt $=$ Application. WorksheetFunction.Max(MatrizGt)

End If

marcha $=$ Application. WorksheetFunction.Match(Gt, MatrizGt, -1)

'Localiza a marcha na MatrizGt

$\mathrm{Gt}=$ Application. WorksheetFunction.Index(MatrizGt, marcha)

'Lê a marcha com maior redução

\section{Lidas as variáveis iniciais e calculadas as variáveis dependentes, escreve-se na primeira linha dos resultados a situação inicial do veículo no trecho e inicia-se o processo iterativo.}

\section{'Escreve a situaç̃o inicial das variáveis, na linha 23, para iniciar as iteracões}

\author{
Range("B26"). Value $=0$ \\ Range("C26").Value = Round (Vel, 2) \\ Range("I26").Value = Round(TempoAcum, 2) \\ Range("H26").Value = Round(S, 2) \\ Range("Q26"). Value = 500 \\ Range("H13").Value = "Simulando"
}

\author{
'Escreve iteração zero \\ 'Escreve a velocidade inicial $[\mathrm{km} / \mathrm{h}]$ \\ 'Escreve o tempo acumulado inicial [min] \\ 'Escreve a posição inicial do veículo [km] \\ 'Escreve a cota inicial do veículo [m] \\ ' Status = Simulando
}

\section{'Início do Processo Iterativo}

Do While Iteracao $<1000000$ And Check $=$ True 'Limita o número de iterações (1 milhão) Iteracao $=$ Iteracao +1

\section{'Calculo da rotação do motor correspondente a velocidade intantânea Vel}

$\begin{array}{ll}\text { Rotacao }=\mathrm{Vel} * \mathrm{Gt} * \mathrm{Gd} /(0.06 * 3.1415 * \text { Diam }) & \text { 'Calcula rotação }[\mathrm{rpm}] \\ \text { Do While Rotacao }>=\text { RotMax And marcha }<=\mathrm{m}-1 & \text { 'Aumenta a marcha se esta não for a última } \\ \text { marcha }=\text { marcha }+1 & \text { 'Proxima marcha }\end{array}$

Gt = Application.WorksheetFunction.Index(MatrizGt, marcha) 'Muda uma marcha a frente

Rotacao $=$ Vel $*$ Gt $*$ Gd $/(0.06 * 3.1415 *$ Diam $) \quad$ 'Recalcula rotação [rpm]

$\mathrm{CDT}=\mathrm{CDT}+1.5 / 3600$

'Tempo de troca de marcha $(1,5 \mathrm{~s})$

Loop

Do While Rotacao <= RotMin

'Reduz a marcha

marcha $=$ marcha -1

'Marcha anterior

Gt = Application.WorksheetFunction.Index(MatrizGt, marcha) 'Muda uma marcha atrás

Rotacao $=\mathrm{Vel} * \mathrm{Gt} * \mathrm{Gd} /(0.06 * 3.1415 *$ Diam $) \quad$ 'Recalcula rotação [rpm]

$\mathrm{CDT}=\mathrm{CDT}+1.5 / 3600$

'Tempo de troca de marcha $(1,5 \mathrm{~s})$

Loop

If marcha $=m$ And Rotacao $>=$ RotMax Then

'Ultima marcha e Rotação máxima

Rotacao $=$ RotMax 
End If

\section{'Calculo da potência fornecida pelo motor em funcão da rotação}

$$
\mathrm{i}=1
$$

Dif = Rotacao - MatrizMotor $(i, 1)$

Do While Dif $>0$

$\mathrm{i}=\mathrm{i}+1$

Dif $=$ Rotacao - MatrizMotor $(i, 1)$

Loop

$\mathrm{i}=\mathrm{i}-1$

Rot1 = MatrizMotor $(\mathrm{i}-1,1)$

Rot2 = MatrizMotor $(\mathrm{i}, 1)$

Pot1 = MatrizMotor $(\mathrm{i}-1,2)$

Pot2 = MatrizMotor (i, 2)

Con1 = MatrizMotor $(\mathrm{i}-1,3)$

Con2 = MatrizMotor(i, 3)

potencia $=\operatorname{Pot} 1+((\operatorname{Rotacao}-\operatorname{Rot} 1) *((\operatorname{Pot} 2-\operatorname{Pot} 1) /(\operatorname{Rot} 2-\operatorname{Rot} 1)))$

'Calcula a potência $[\mathrm{kW}]$

If $\mathrm{Vel}>40$ Then

potencia $=$ potencia $*$ Condutor 'Ajusta a potência ao condutor

End If

ConsumoEsp $=$ Con $1+(($ Rotacao - Rot 1$) *((\operatorname{Con} 2-\operatorname{Con} 1) /(\operatorname{Rot} 2-\operatorname{Rot} 1))) \quad$ 'Calcula o consumo específico $[\mathrm{g} / \mathrm{kW} . \mathrm{h}]$

Tracao $=3.6 *$ Efic $*$ potencia $/$ Vel

'Calcula a força de tração $[\mathrm{kN}]$

'Calculo da resistência ao movimento

inclinacao $=$ MatrizTre $($ trecho, 2)

'Lê a inclinação do trecho [\%]

ResisRol $=(7.6+(0.056 * \mathrm{Vel})) *($ PBTC / 1000) $* 9.82$

'Resistência de Rolamento [N]

ResisAero $=0.04 * 7.5 *(\mathrm{Vel} \wedge 2)$

'Resistência Aerodinâmica [N]

ResisGrad $=10 *($ PBTC / 1000) $* 9.82 *$ inclinacao

'Resistência de Rampa [N]

ResisTotal $=($ ResisRol + ResisAero + ResisGrad $) / 1000$

'Resistência Total [kN]

\section{'Calculo da aceleração do veículo}

Aceleracao $=($ Tracao - ResisTotal $) /($ PBTC $/ 1000) \quad$ 'Calcula a aceleração $[\mathrm{kN} /$ ton $]$ ou $[\mathrm{m} / \mathrm{s} 2]$

$\mathrm{DS}=(\mathrm{Vel} * 0.05 / 3600)+\left(\right.$ Aceleracao $\left.*\left(\left(0.05^{\wedge} 2\right) / 2000\right)\right)$ 'Calcula o deslocamento DS $[\mathrm{km}]$

$\mathrm{CDS}=\mathrm{CDS}+\mathrm{DS} \quad$ 'Contador de deslocamento CDS [km]

$\mathrm{S}=\mathrm{S}+\mathrm{DS} \quad$ 'Calcula a posição $\mathrm{S}[\mathrm{km}]$

If ResisTotal $>0$ Then

Consumo $=$ ConsumoEsp $*$ potencia $* 0.05 / 3600 \quad$ 'Consumo de combustível $[\mathrm{g}]$ 
ConsumoAc $=$ ConsumoAc + Consumo

Emissao $=($ Consumo $/ 0.845) * 2.75$

EmissaoAc $=$ EmissaoAc + Emissao

End If

$\mathrm{CDT}=\mathrm{CDT}+0.05 / 3600$

TempoAcum $=$ TempoAcum $+(0.05 * 60 / 3600)$

$\mathrm{Vel}=\mathrm{Vel}+($ Aceleracao $* 0.05 * 3.6)$

If $\mathrm{Vel}>=$ VelMax Then

$\mathrm{Vel}=\mathrm{VelMax}$

End If

If Vel $>=$ VelLimite Then

Vel $=$ VelLimite

End If
'Consumo acumulado nas iterações [g]

'Emissão de CO2 [g]

'Emissão acumulada de CO2 [g]

'Contador de tempo [h]

'Calcula o tempo acumulado TempoAcum [min]

'Recalcula a velocidade alterada por uma aceleração

Ao final de cada iteração, verifica-se o critério para impressão dos resultados e escreve-se os resultados na planilha.

\section{'Permissão para escrever os dados na tela}

If Abs(Aceleracao) > 0.01 And CDS > 0.005 Then

If CDS > 0.005 Then

Escrever $=$ True

End If

\section{'Verifica se chegou ao fim do trecho e avança no espaço}

If $\mathrm{S}>=$ MatrizTre(trecho, 1) / 1000 + Percorrido Then

'Vai para o próximo trecho

Percorrido $=$ Percorrido + MatrizTre $($ trecho, 1$) / 1000$

'Soma dos trechos já percorridos

trecho $=$ trecho +1

End If

If trecho $=\mathrm{j}$ Then

'Verifica de chegou ao fim dos trechos

Check $=$ False

Escrever $=$ True

End If

\section{'Escreve os resultados}

If Escrever $=$ True Then

Cells $($ Linha, 13). Value $=$ Round $($ ResisTotal, 2$)$

'Escreve a Resistência Total [kN]

Cells $($ Linha, 15) .Value = Round(inclinacao, 2$)$

'Escreve a Inclinacao do trecho [\%] 
Cells $($ Linha, 16).Value $=$ Round $($ trecho, 2)

Cells $($ Linha, 5$)$. Value $=$ Round $($ Tracao, 2$)$

Cells $($ Linha, 11).Value $=$ Round $($ Aceleracao, 4$)$

Cells $($ Linha, 6). Value $=$ Round $($ CDT $* 60 * 60,2)$

Cells (Linha, 9).Value $=$ Round (TempoAcum, 2)

Cells $($ Linha, 7).Value $=$ Round $(\operatorname{CDS} * 1000,2)$

Cells $($ Linha, 8). Value $=\operatorname{Round}(S * 1000,2)$

Cells $($ Linha, 10).Value $=$ Round $($ potencia, 2$)$

Cells $($ Linha, 2). Value = Iteracao

Cells $($ Linha, 3).Value $=$ Round $($ Vel, 2)

Cells $($ Linha, 4$)$. Value $=$ Round $($ Rotacao, 0$)$

Cells $($ Linha, 12). Value $=\mathrm{Gt}$

Cells $($ Linha, 14).Value $=$ marcha

Cells $($ Linha, 17).Value $=$ Round $($ Cells $($ Linha $-1,17)$. Value $+\operatorname{CDS} *$ inclinacao $* 10,2)$

'Escreve a Cota do greide [m]

Cells $($ Linha, 18$)$. Value $=$ Round $($ ConsumoAc $/(\operatorname{CDS} * 1000 * 0.74), 3)$

'Escreve o consumo específico $[\mathrm{ml} / \mathrm{m}]$, para $0,74 \mathrm{~g} / 1$

Cells $($ Linha, 19). Value $=$ Round $($ ConsumoAc $/ 0.845,3)$

Cells $($ Linha, 20). Value $=\operatorname{Round}($ EmissaoAc $)$

'Escreve o consumo acumulado [ml]

'Escreve o consumo acumulado [ml]

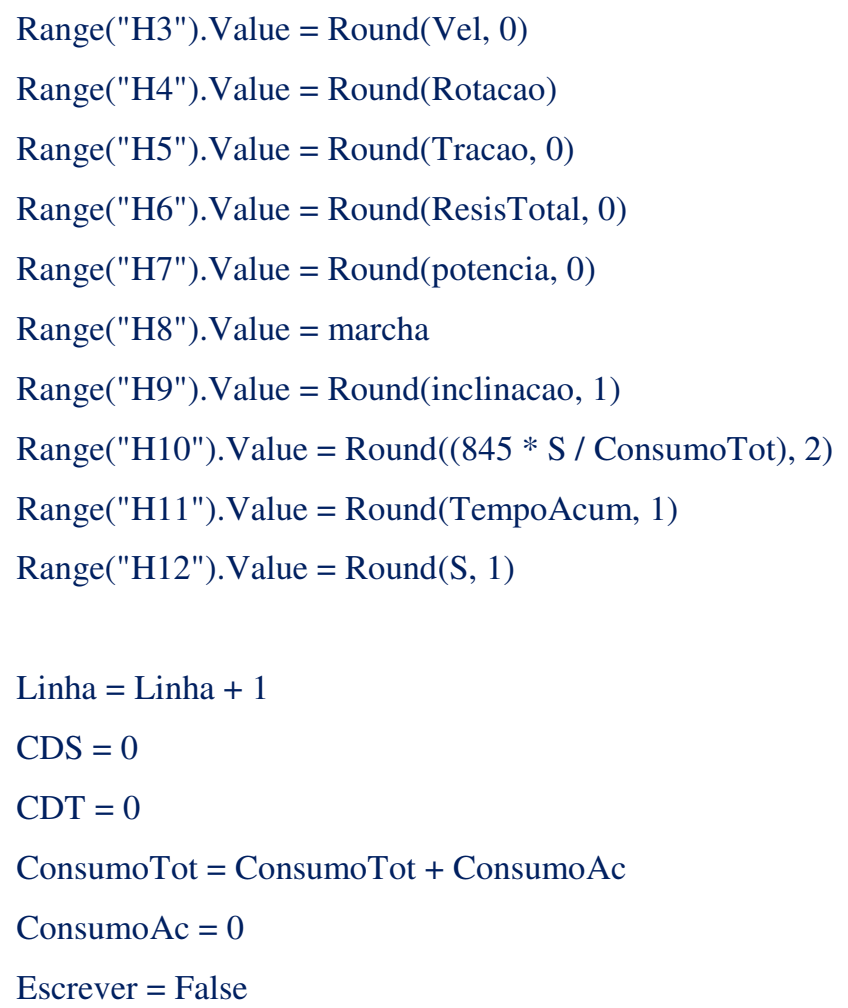

End If

Loop 
Range("H3").Value = ""

Range("H4").Value = ""

Range("H5").Value = ""

Range("H6").Value = ""

Range("H7"). Value = ""

Range("H8").Value = ""

Range("H9").Value = ""

Range("H11").Value = Round(TempoAcum, 1)

Range("H12").Value = Round $(S, 1)$

End Sub

\section{2) Cálculos Estáticos}

O algoritmo de cálculos estáticos efetua os cálculos que não são iterativos, como: Curvas de Tração, Curvas de Resistência, Distância de Visibilidade e Parada, Frenagem Motora e Estabilidade, como indica o fluxograma do algoritmo na Figura 44.

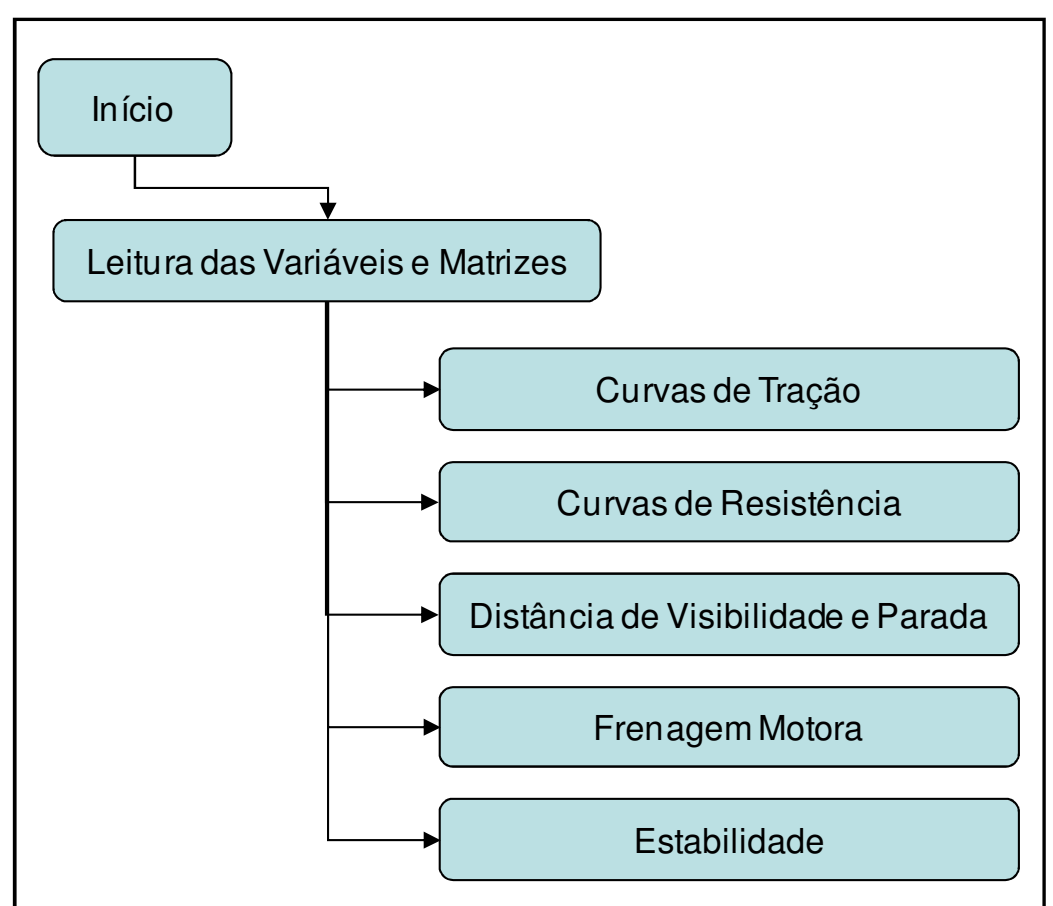

Figura 44: Fluxograma do algoritmo de cálculos estáticos 


\section{Inicialmente são lidos os dados necessários aos cálculos,.}

Sub Calcular_Curvas()

Sheets("CALCULO").Range("B10:P3000").ClearContents

\section{'Leitura dos dados}

Gd = Worksheets("ENTRADA").Range("H52").Value

'Lê a redução do diferencial

Diam = Worksheets("ENTRADA").Range("H23").Value

'Lê o diâmetro dinâmico do pneumático [m]

PBTC $=$ Worksheets("ENTRADA").Range("H11").Value * 1000 'Lê o PBTC [kg]

Efic $=$ Worksheets("ENTRADA").Range("H37").Value ～'Lê a eficiência da transmissão [0 a 1]

\section{'Lê a matriz da caixa de mudancas diretamente no banco de dados}

$\mathrm{i}=$ Worksheets("ENTRADA").Range("H39")

$\mathrm{m}=$ Worksheets("ENTRADA").Range("H43")

With Worksheets("MCMU")

Set MatrizGt $=$. Range $($. Cells $(\mathrm{i}, 3),$. Cells $(\mathrm{i}, \mathrm{m}+2))$ 'Lê as reduções

End With

\section{'Lê a matriz motor}

Dim MatrizMotor(21, 3) As Single

Linha = Worksheets("ENTRADA").Range("H29")

'Linha do motor na matriz MMOT

Coluna $=$ Worksheets("MMOT").Cells(Linha, 51)

For $\mathrm{i}=1$ To Coluna

MatrizMotor(i, 1) = Worksheets("MMOT").Cells $(1, \mathrm{i}+8)$

'Lê a rotação

MatrizMotor(i, 2) = Worksheets("MMOT").Cells(Linha, i + 8)

'Lê a Potencia

MatrizMotor(i, 3) = Worksheets("MMOT").Cells(Linha, i + 29)

'Lê o consumo

Next i

RotMax = MatrizMotor $(1,1)$

For $\mathrm{i}=1$ To Coluna -1

If MatrizMotor $(i+1,1)>$ MatrizMotor $(i, 1)$ Then

RotMax $=$ MatrizMotor $(\mathrm{i}+1,1)$

End If

Next i

RotMin $=1000$

Em seguida são efetuados os cálculos do fluxograma da Figura 44.

\section{'Calculo das curvas de tracão}

Sheets("CALCULO").Select 
$\mathrm{i}=10$ 'Linha inicial

$\mathrm{j}=1$ 'Marcha inicial

Do While $\mathrm{j}<=\mathrm{m} \quad$ 'limite das marchas

Rotacao $=1000$

$\mathrm{h}=0$

Do While Rotacao <= RotMax

'limite rotações

$\mathrm{h}=\mathrm{h}+1$

$\mathrm{Gt}=$ Application.WorksheetFunction.Index $($ MatrizGt, j) 'Define Redução da Caixa de Mudanças Cells $(\mathrm{i}, 2)=0.06 * 3.1415 *$ Diam $*$ Rotacao $/(\mathrm{Gd} * \mathrm{Gt}) \quad$ 'Calcula a Velocidade e Plota

If Cells $(\mathrm{i}, 2)=0$ Then $\quad$ 'Pula linha quando Vel $=0$

Cells $(\mathrm{i}, 2)=" "$

End If

Pot1 = MatrizMotor(h, 2)

Cells $(\mathrm{i}, 3)=3.6 *$ Efic $*$ Pot1 $/$ Cells $(\mathrm{i}, 2)$

If Cells $(i, 3)=0$ Then

Cells $(\mathrm{i}, 3)=$ ""

End If

Rotacao $=$ Rotacao +100

$\mathrm{i}=\mathrm{i}+1$

Loop

$\mathrm{i}=\mathrm{i}+1$

$\mathrm{j}=\mathrm{j}+1$

Loop

\section{'Calculo das Curvas de resistência ao movimento}

inclinacao $=-10$

$\mathrm{i}=10$

Do While inclinacao $<=10$

$\mathrm{Vel}=0$

VelMax $=\operatorname{RotMax} * 0.06 * 3.1415 *$ Diam / (Application.WorksheetFunction.Min(MatrizGt) $* \mathrm{Gd})$

Do While Vel <= VelMax

$\operatorname{Cells}(\mathrm{i}, 4)=\mathrm{Vel}$

Cells $(\mathrm{i}, 5)=(7.6+(0.056 * \mathrm{Vel})) *(\mathrm{PBTC} / 1000) * 9.82$ 'Resistência de Rolamento [N]

Cells $(\mathrm{i}, 6)=0.04 * 7.5 *\left(\mathrm{Vel}^{\wedge} 2\right)$ 'Resistência Aerodinâmica [N]

Cells $(\mathrm{i}, 7)=10 *(\mathrm{PBTC} / 1000) * 9.82 *$ inclinacao 'Resistência de Rampa [N]

Cells $(\mathrm{i}, 8)=(\operatorname{Cells}(\mathrm{i}, 5)+\operatorname{Cells}(\mathrm{i}, 6)+\operatorname{Cells}(\mathrm{i}, 7)) / 1000 \quad$ 'Resistência Total $[\mathrm{kN}]$

\section{'Calculo da Distancia Visibilidade de Parada (D) - AASHTO (1994)}

tr = Worksheets("ENTRADA").Range("H69").Value

eficienciafreio = Worksheets("ENTRADA").Range("H28").Value 
atrito = Worksheets("ENTRADA").Range("H63").Value 'Atrito AASHTO

Cells $(\mathrm{i}, 9)=\operatorname{Cells}(\mathrm{i}, 4) * \operatorname{tr} / 3.6 \quad$ 'Distancia de reação

Cells $(\mathrm{i}, 10)=$ eficienciafreio $* \operatorname{Cells}(\mathrm{i}, 4) \wedge 2 /(250 *($ atrito $+0.01 *$ inclinacao $))$ 'Distancia de frenagem

Cells $(\mathrm{i}, 11)=\operatorname{Cells}(\mathrm{i}, 9)+\operatorname{Cells}(\mathrm{i}, 10)$

\section{'Frenagem motora}

If $\mathrm{Vel}=0$ Then

Potfrenagem = Worksheets("ENTRADA").Range("H34").Value

NConjuntos = Worksheets("ENTRADA").Range("H10").Value

CoefTemp = Worksheets("ENTRADA").Range("H24").Value

PesoFreio = Worksheets("ENTRADA").Range("H25").Value

Else

Cells $(\mathrm{i}, 12)=-(\operatorname{Cells}(\mathrm{i}, 8) * 1000 *$ Vel / 3.6) $-(746 * 0.986 *$ PotFrenaegem $)$ 'Potencia Dissipada

Cells $(\mathrm{i}, 13)=\operatorname{Cells}(\mathrm{i}, 12) * 3600 * 6 / \mathrm{Ve} \quad$ 'Energia Dissipada, 6 é o comprimento em km

Cells $(\mathrm{i}, 14)=$ Cells $(\mathrm{i}, 13) /($ NConjuntos $*$ CoefTemp $*$ PesoFreio $)$

If Cells $(i, 14)<0$ Then

Cells $(\mathrm{i}, 14)=0$

Cells $(i, 15)=$ "suficiente"

Cells(i, 16) = "não utilizado"

ElseIf $0<$ Cells(i, 14) And Cells(i, 14) < 50 Then

Cells $(i, 15)=$ "não suficiente"

Cells $(i, 16)=$ "suficiente"

Else

Cells(i, 15) = "não suficiente"

Cells $(i, 16)=$ "não suficiente"

End If

End If

$\mathrm{Vel}=\mathrm{Vel}+1$

$\mathrm{i}=\mathrm{i}+1$

Loop

$\mathrm{i}=\mathrm{i}+1$

inclinacao $=$ inclinacao +2

Loop

End Sub 


\section{ANEXO C - Manual do usuário}

A planilha eletrônica SimVC está estruturada em pastas e algoritmos. As pastas servem para armazenar dados, gerar cenários e imprimir os resultados das simulações. Os algoritmos lêem os cenários e dados armazenados, efetuam os cálculos e imprimem os resultados na pasta apropriada.

\section{1) Pastas para armazenamento}

Para armazenar os dados dos veículos e das rodovias, necessários à configuração de cenários para execução dos algoritmos, foram criadas sete pastas dentro de um arquivo de Excel, descritas à seguir.

a) MCVC - "Matriz de Caminhões e CVCs"

Armazena os dados referentes aos veículos unitários ou CVCs, como: número de eixos, PBTC máximo, dimensões dos veículos (largura e comprimento da(s) unidade(s)) e tipo de composição.

Tabela 13: Dados armazenados na pasta MCVC

\begin{tabular}{|c|c|c|c|c|c|c|}
\hline CVC & $\begin{array}{c}\text { PBTC Maxi- } \\
\text { mo } \\
(t)\end{array}$ & $\begin{array}{l}\text { Carga má- } \\
\text { xima sobre } \\
\text { cada eixo } \\
\text { trator [t] }\end{array}$ & $\begin{array}{l}\text { Número de } \\
\text { conjuntos } \\
\text { de freio } \\
\text { auxiliares }\end{array}$ & $\begin{array}{l}\text { Sugestões } \\
\text { configuração } \\
\text { caminhão }\end{array}$ & $\begin{array}{l}\text { Potência } \\
\text { Mínima de } \\
\text { frenagem } \\
\text { motora (cv) } \\
\text { "ECE-R13" }\end{array}$ & $\begin{array}{l}\text { Potência / } \\
\text { Massa } \\
\text { Mínima } \\
\text { “ECE-R13" }\end{array}$ \\
\hline U11 & 16 & 10 & 4 & $4 \times 2$ & 96,09 & 6,01 \\
\hline U12 & 23 & 8,5 & 6 & $6 \times 2$ ou $6 \times 4$ & 139,46 & 6,06 \\
\hline 11S1 & 26 & 10 & 6 & $4 \times 2$ & 158,05 & 6,08 \\
\hline $11 S 2$ & 33 & 10 & 8 & $4 \times 2$ & 201,43 & 6,10 \\
\hline 1153 & 41,5 & 10 & 10 & $4 \times 2$ & 254,10 & 6,12 \\
\hline $12 S 3$ & 45 & 8,5 & 12 & $6 \times 2$ ou $6 \times 4$ & 275,79 & 6,13 \\
\hline 12S2B2 & 57 & 8,5 & 14 & $6 \times 2$ ou $6 \times 4$ & 350,14 & 6,14 \\
\hline U12A1S1 & 43 & 8,5 & 10 & $6 \times 2$ ou $6 \times 4$ & 263,39 & 6,13 \\
\hline
\end{tabular}

Para atender a condição de equilíbrio recomendada pela ECE-R13 (velocidade constante mínima de $30 \mathrm{~km} / \mathrm{h}$ em declive com inclinação $6 \%$ ), o valor da 
potência mínima de frenagem motora é calculado pela aplicação da equação 13 nas células da 6 6 $^{\mathrm{a}}$ coluna, conforme Tabela 13, com a condição de potência dissipada pelo sistema de freios auxiliares igual a zero $\left(\mathrm{P}_{\mathrm{B}}=0\right)$ e demais coeficientes adotados na pasta "ENTRADA" (ver Item 2 deste Anexo), de acordo com a realidade da operação em estudo.

Neste caso, o valor resultante representa a potência mínima que deve ter o motor da unidade tratora para atender uma das exigências da norma européia. A coluna $G$ calcula a relação entre a potência mínima calculada na coluna $F$ pelo PBTC máximo do veículo ou da unidade tratora.

As demais colunas desta pasta são de livre utilização, podendo armazenar os dados da geometria do veículo, como bitola, balanços dianteiro e traseiro, distâncias entre eixos, etc.

b) MCAM - "Matriz das Unidades Tratoras"

Armazena os dados referentes às unidades tratoras (cavalo mecânico) dos veículos unitários ou CVCs, como: identificação da unidade tratora, fabricante e modelo, tipo de tração $(4 \times 2,4 \times 4,6 \times 2,6 \times 4)$, número de eixos tratores, e colunas para descrição dos tipos de motores, diferenciais, caixas de mudanças e pneumáticos compatíveis com a unidade tratora. A Tabela 14 exemplifica como os dados são armazenados.

\section{Tabela 14: Dados armazenados na pasta MCAM}

\begin{tabular}{|l|c|c|c|c|c|c|c|}
\hline $\begin{array}{l}\text { Unidade } \\
\text { Tratora }\end{array}$ & $\begin{array}{c}\text { Fabricante } \\
\text { e Modelo }\end{array}$ & $\begin{array}{c}\text { Tipo de } \\
\text { Tração }\end{array}$ & $\begin{array}{c}\text { Número } \\
\text { de eixos } \\
\text { tratores }\end{array}$ & $\begin{array}{c}\text { Motores } \\
\text { Compatíveis }\end{array}$ & $\begin{array}{c}\text { Caixas de } \\
\text { Compatíveis }\end{array}$ & $\begin{array}{c}\text { Pneumáticos } \\
\text { Companças } \\
\text { Compatíveis }\end{array}$ \\
\hline VM23 & Volvo & $6 \times 2$ & 1 & MWM60240 & RSS1035 B & FT0906 C & $275 / 80 R 22,5$ \\
\hline FM12 & Volvo & $4 \times 2$ & 1 & D12D340 & CTN 372 & VT 2214 & $295 / 80 R 22,5$ \\
\hline LS1634 & MB & $4 \times 2$ & 1 & MB.OM447LA & MB HL7/022D & ZF 16S 1650 & $295 / 80 R 22,5$ \\
\hline C1521 & Ford & $4 \times 2$ & 1 & C. B5.9(208) & M.RS23-230 & Eaton 365 & $275 / 80 R 22,5$ \\
\hline $\mathbf{1 7 . 2 1 0 C}$ & VW & $4 \times 2$ & 1 & C. 6BTAA & M.RS23-240 & E.FS-5306-A & 10.00 R20-PR16 \\
\hline
\end{tabular}


c) MMOT - "Matriz dos Motores"

Armazena os dados referentes aos motores das unidades tratoras, como: potência nominal máxima, potência de frenagem motora, curva de potência (um valor de potência para cada valor de rotação, de 1000 a 3000rpm), curva de consumo específico (análoga à curva de potência).

d) MMUD - "Matriz de Caixas de Mudanças"

Armazena os dados referentes às caixas de mudanças de unidades tratoras, como: fabricante, modelo, número de relações da caixa de mudanças e valor de cada redução, para um máximo de 16 valores diferentes.

e) MDIF - "Matriz de Diferenciais"

Armazena os dados referentes aos diferenciais de unidades tratoras, como: fabricante, modelo, Capacidade Máxima de Tração - CMT, e relações de redução.

f) MROD - "Matriz de Rodovias ou Trechos de Rodovias"

Armazena comprimento e inclinações dos trechos de rodovias que compõe um perfil longitudinal de rodovias ou trecho de rodovia.

g) MVEI - "Matriz de Veículos"

Armazena cenários configurados previamente, permitindo agilidade nas simulações e recuperação de cenários já utilizados. 


\section{2) ENTRADA}

A pasta "ENTRADA" permite a configuração de cenários de simulação, mediante a escolha de dados cadastrados nas sete pastas de armazenamento de dados (MCVC, MCAM, MMOT, MMUD, MDIF, MROD e MVEI) e caso necessário a alteração de coeficientes e parâmetros como: PBTC da simulação, carga sobre os eixos tratores, coeficientes de resistência ao movimento, etc.

A Figura 45 mostra a visualização da pasta ENTRADA que o usuário encontra ao abrir o arquivo SimVC.xlsm.

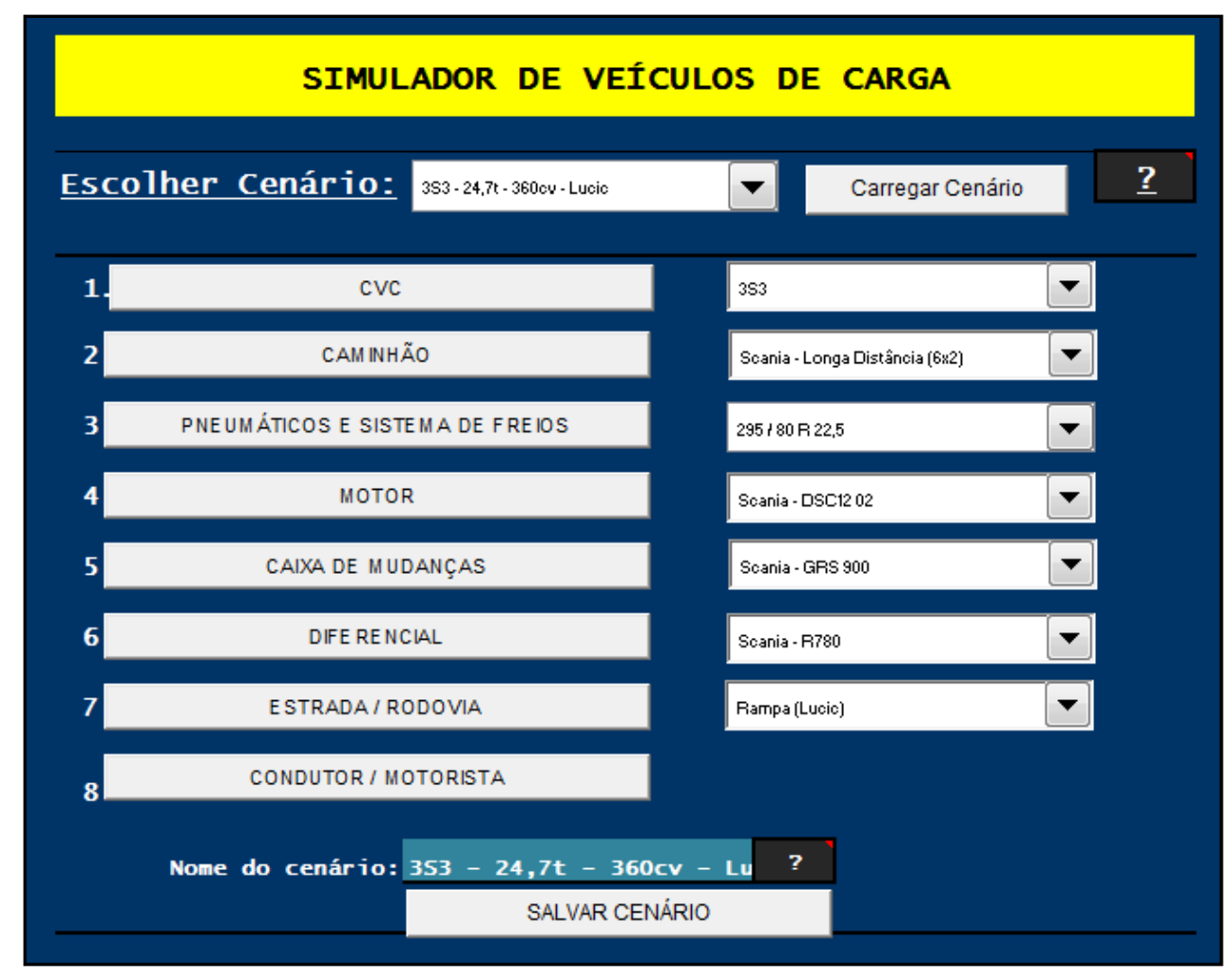

Figura 45: Interface - SimVC (Simulador de Veículos de Carga)

Os botões de 1 a 8 (CVC, Caminhão, Pneumáticos e Sistema de Freios, Motor, Caixa de Mudanças, Diferencial, Estrada/Rodocia, Condutor) abrem as interfaces que permitem a edição dos parâmetros correspondentes, bastando para isso clicá-los. 
As caixas de seleção servem para selecionar dados salvos nas pastas de banco de dados.

A primeira caixa de seleção disponibiliza cenários salvos pelo próprio usuário. Para arbri-los, basta selecionar o cenário desejado e clicar no botão "CARREGAR CENÁRIO". Caso o objetivo seja iniciar um novo cenário, basta alterar as configurações exibidas na tela, clicando nos botões de 1 a 8.

Após alterar as configurações, é possível salvar as alterações como um novo cenário. Para isso, insira um nome no campo "Nome do cenário" e clique no botão "SALVAR CENÁRIO".

Para informações adicionais, passe o mouse sobre as caixas que contém o sinal de interrogação, que automaticamente são exibidas dicas de utilização de SimVC. Como a planilha é aberta, o usuário pode criar novos campos com dicas de utilização, conforme julgar necessário.

Ao clicar no botão 1, "CVC", é aberta a caixa de edição para alterar parâmetros correspondentes ao caminhão ou CVC escolhido na caixa de seleção correspondente.

\begin{tabular}{|l|c|}
\hline \hline \multicolumn{1}{|c|}{ CVC } & \multicolumn{1}{|c|}{353} \\
CVC: & 45,00 \\
PBTC máximo: & $\mathbf{8 , 5 0}$ \\
Carga máxima sobre cada eixo trator: & $\mathbf{1 2 , 0 0}$ \\
Conjuntos de freios auxiliares (2 x número de eixos) & $\mathbf{4 4 , 1 0}$, \\
PBTC: & $\mathbf{8 , 5 0}$
\end{tabular}

Figura 46: Caixa de edição - caminhão/CVC

Utilize as ferramentas de controle disponíveis em cada linha da caixa de edição para alterar os parâmetros desejados. 
Analogamente é possível editar cada uma das oito caixas de seleção que são abertas ao clicar nos botões correspondentes. Para fechar cada caixa de edição basta clicar novamente no mesmo botão. As Figuras 47 a 53 apresentam as demais caixas de seleção.

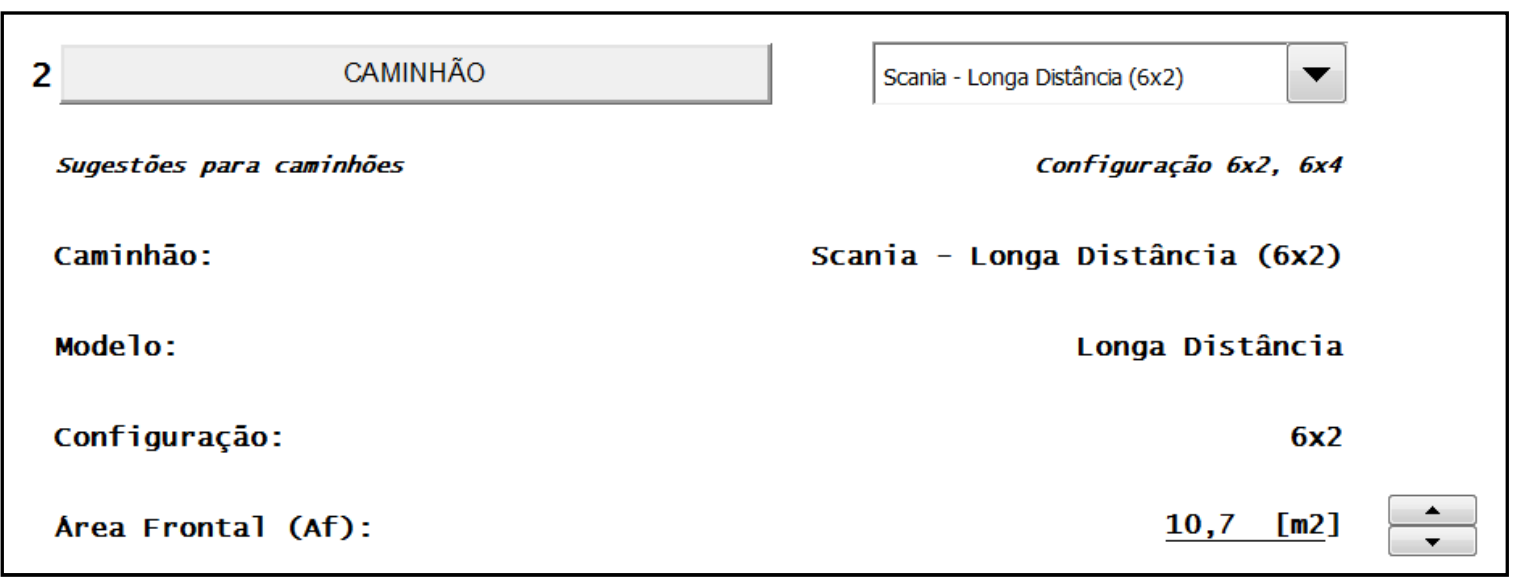

Figura 47: Caixa de edição - unidade tratora

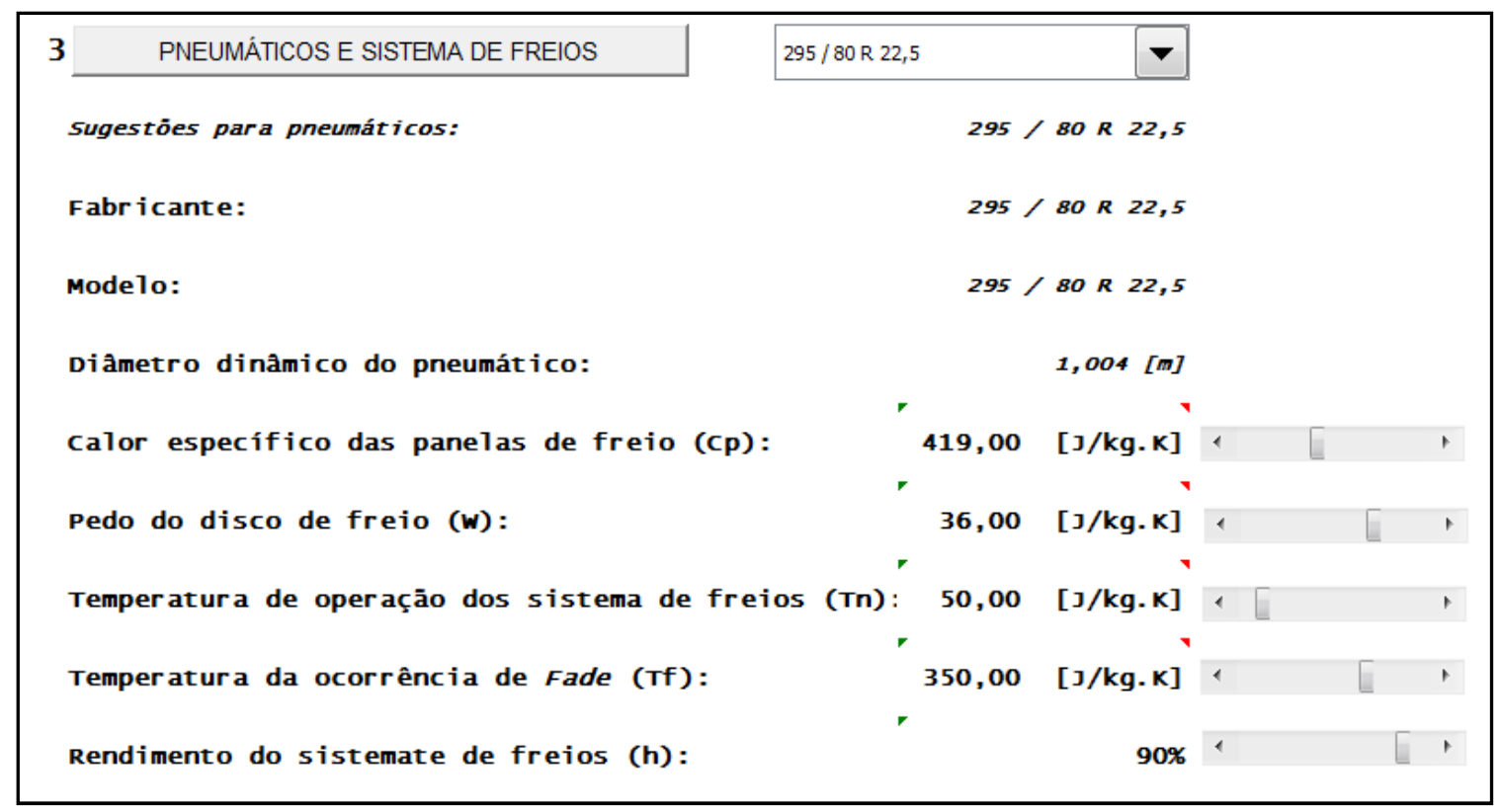

Figura 48: Caixa de edição - pneumáticos e sistema de freios 


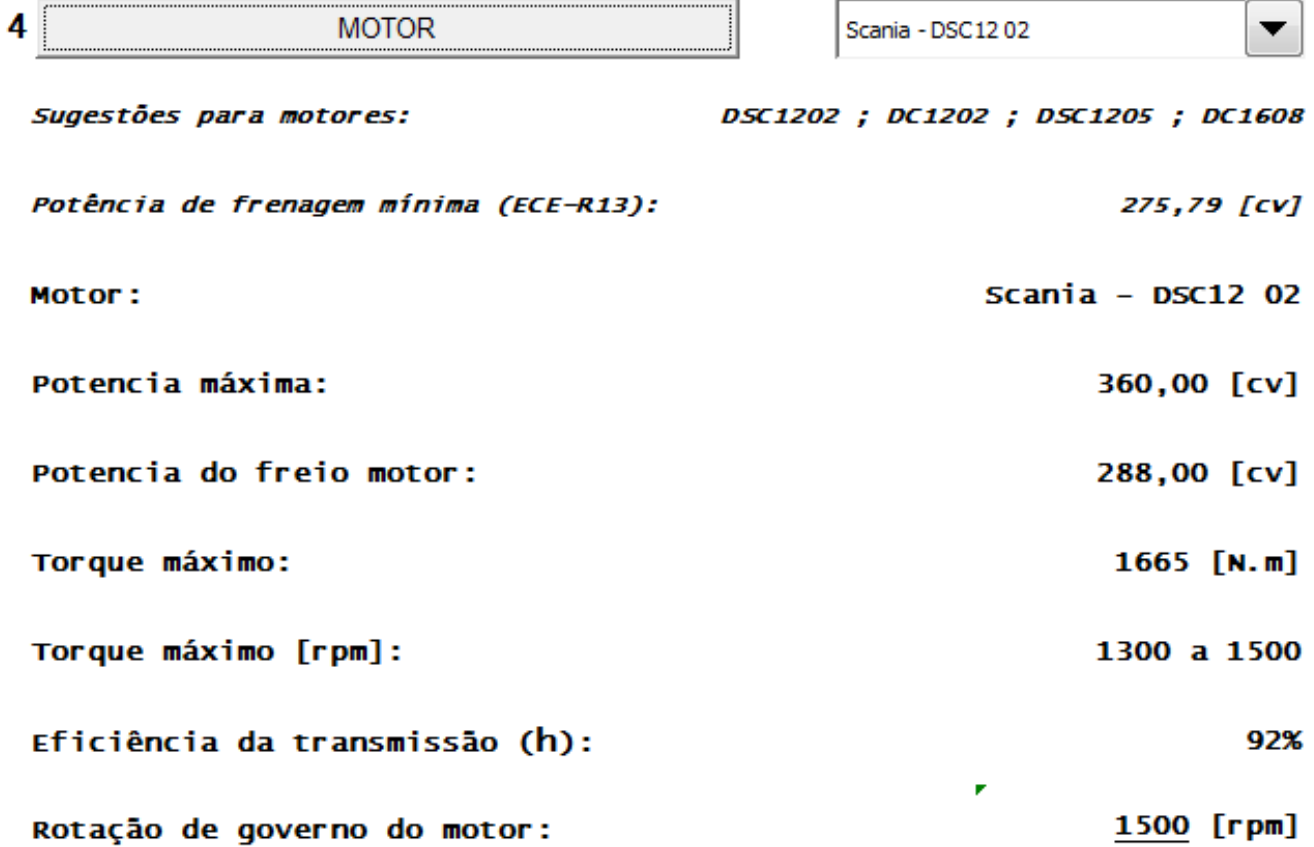

Figura 49: Caixa de edição - motor

\begin{tabular}{l|r|}
\hline \multicolumn{1}{c|}{ CAIXA DE MUDANÇAS } & Scania-GRS 900 \\
\hline Sugestões para Caixas de Mudanças: & GR900; GR900R ; GRS900; GRS900R \\
Caixa de Mudanças: & Scania - GRS 900 \\
Modelo: & GRS 900 \\
Número de marchas: & 14
\end{tabular}

Figura 50: Caixa de edição - caixa de mudanças 
6 DIFERENCIAL

Sugestöes para diferenciais:

Diferencial:

Modelo:

Relaçōes de redução disponíveis:

Reduçāo escolhida (gd):

Capacidade Máxima de Tração (CMT):

Modelo

Figura 51: Caixa de edição - diferencial

7.1 Geometria
Comprimento do trecho:
Inclinação (declividade):
7.2 Coeficientes
Constante de deformação do pneu e da via (C1):
Constante de outros fatores da resistência de rol
Coeficiente de tração estático pneu-via do contRt
Coeficiente de tração estático pneu-via da AASHTC

Figura 52: Caixa de edição - estrada/rodovia 


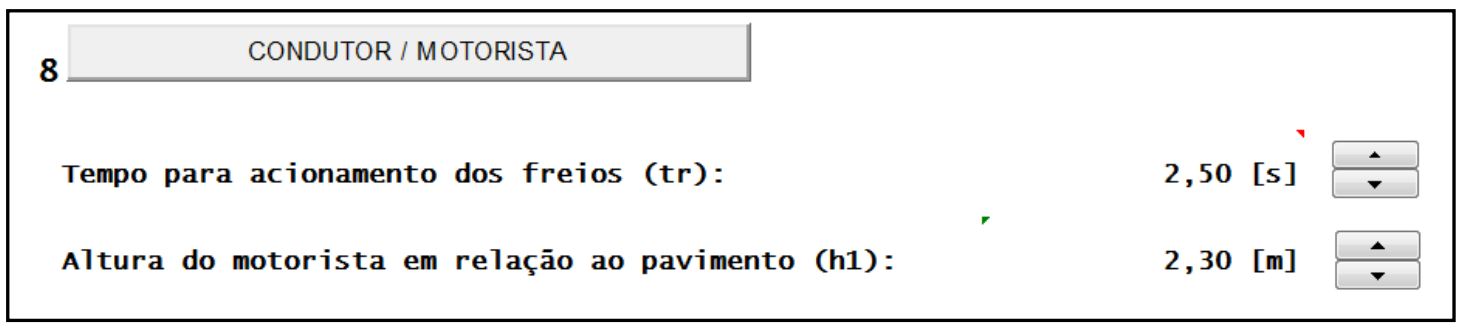

Figura 53: Caixa de edição - condutor/motorista

\section{3) Simulador}

A pasta "SIMULADOR" exibe o resumo do cenário configurado e permite ao usuário acionar as macros que executam os cálculos ou simulações, através de botões interativos.

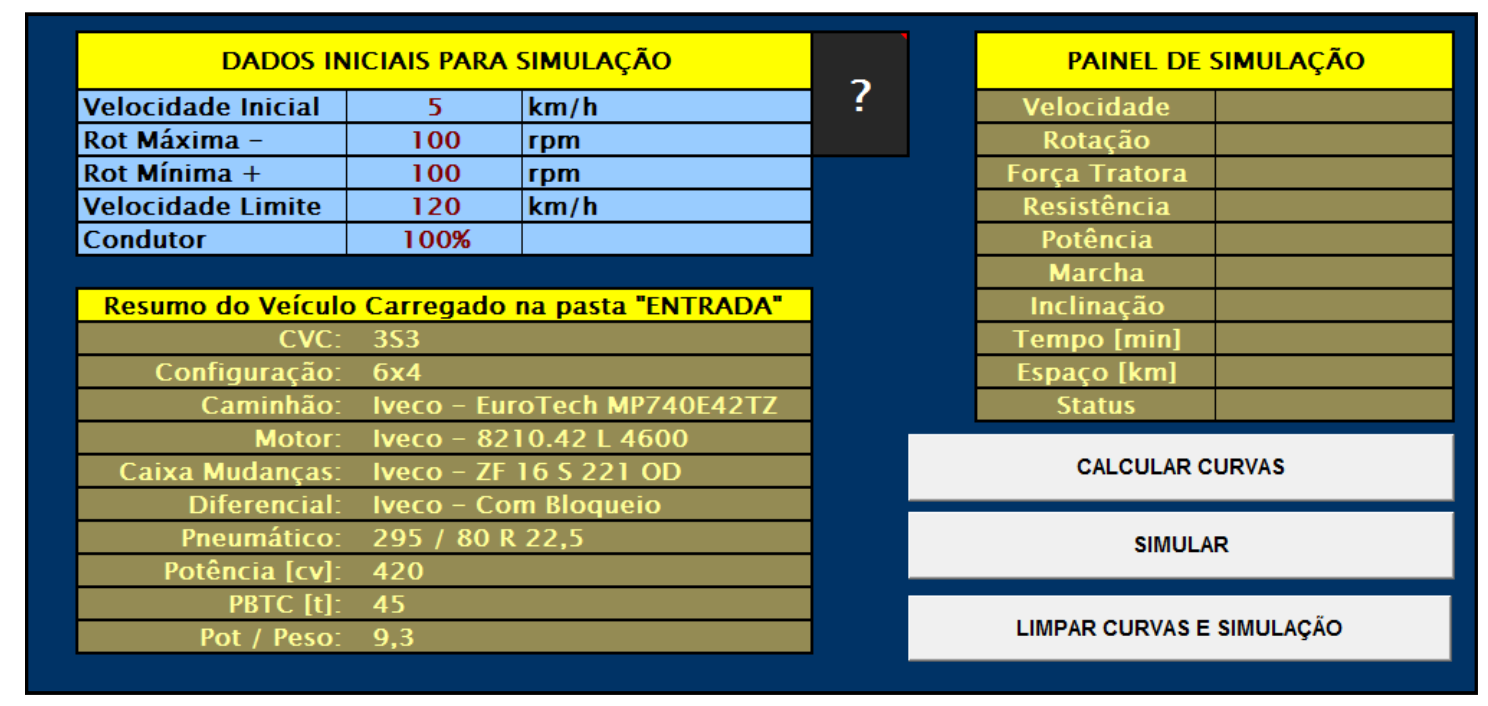

Figura 54: Pasta "SIMULADOR"

Para iniciar uma simulação é necessário definir a Velocidade Inicial, as rotações limites para troca de marchas, a velocidade limite da via e a porcentagem da potência motora utilizada pelo condutor.

Uma ficha resumo do "veículo carregado" e ou editado na pasta ENTRADA é exibida também. Ao clicar no botão SIMULAR, tem início a simulação, cujos resultados podem ser acompanhados, enquanto o algoritmo efetua os cálculos, no "painel de simulação". 
O botão "CALCULAR CURVAS" inicia o algoritmo de cálculos estáticos, enquanto que o botão "LIMPAR CURVAS E SIMULAÇÕES" apaga as simulações anteriores.

Os resultados são plotados na própria pasta "SIMULADOR", na pasta auxiliar "CÁLCULOS" e exibidos nas pastas Gráf 1 a 3, sendo respectivamente, Perfil de velocidade e do terreno, Perfil de rotações e consumo de combustível, e Curvas de Tração, Resistência ao movimento e Distância de Visibilidade e Parada. 


\section{ANEXO D - Verificação da acurácia do algoritmo}

Lucic (2001), em sua dissertação de mestrado, coletou os perfis de aceleração de um veículo com diferentes situações de carregamento. Com os dados coletados calibrou um micro-simulador semelhante ao desenvolvido neste trabalho, e determinou os parâmetros da Tabela 15 como representativos do cenário analisado.

\section{Tabela 15: Parâmetros utilizados nas simulações feitas por Lucic, 2001}

\begin{tabular}{|c|c|}
\hline Parâmetro & Valor \\
\hline Potência nominal do motor & $350 \mathrm{hp}$ \\
\hline PBTC (t) & $22,24,27,29,31,34,36,39,41$ e 44 \\
\hline Eficiência da transmissão & $94 \%$ \\
\hline Área frontal $\left(\mathrm{m}^{2}\right)$ & 10,7 \\
\hline$C_{d}$ & 0,78 \\
\hline$C_{h}$ & 0,95 \\
\hline $\mathrm{C}_{1}$ & 0,04728 \\
\hline $\mathrm{C}_{2}$ & 0,0328 \\
\hline $\mathrm{C}_{3}$ & 4,58 \\
\hline $\mathbf{C}_{\mathrm{r}}$ & 1,25 \\
\hline
\end{tabular}

Para verificação de SimVC frente os dados coletados de Lucic, foram simulados os cenários com PBTC 24t e 44t, adotando para o valor dos demais parâmetros os propostos na Tabela 15.

Para as demais verificações, foram utilizados os coeficientes apresentados na Tabela 6, conforme proposto por Melo (2002)

Os gráficos contendo os perfis de velocidade apresentados nas Figuras A, B e $C$ são repetidos a seguir, ampliados, nas Figuras 55, 56 e 57 respectivamente. A Figura 58 apresenta o perfil de rotações correspondente a Figura 57 e aos veículos que utilizam $100 \%$ da potência disponível. 


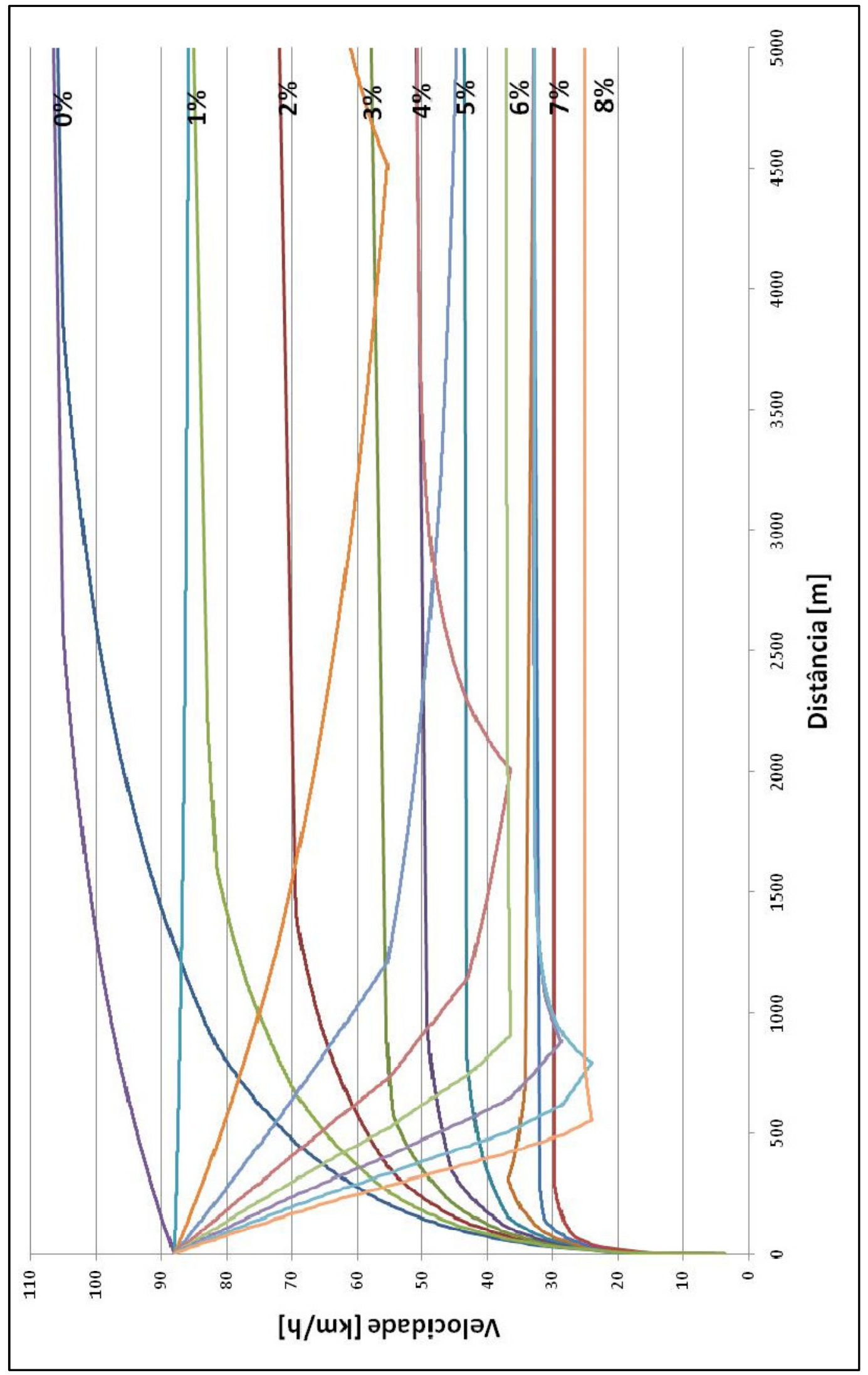

Figura 55: Perfil de velocidades: curvas de aceleração e desaceleração 


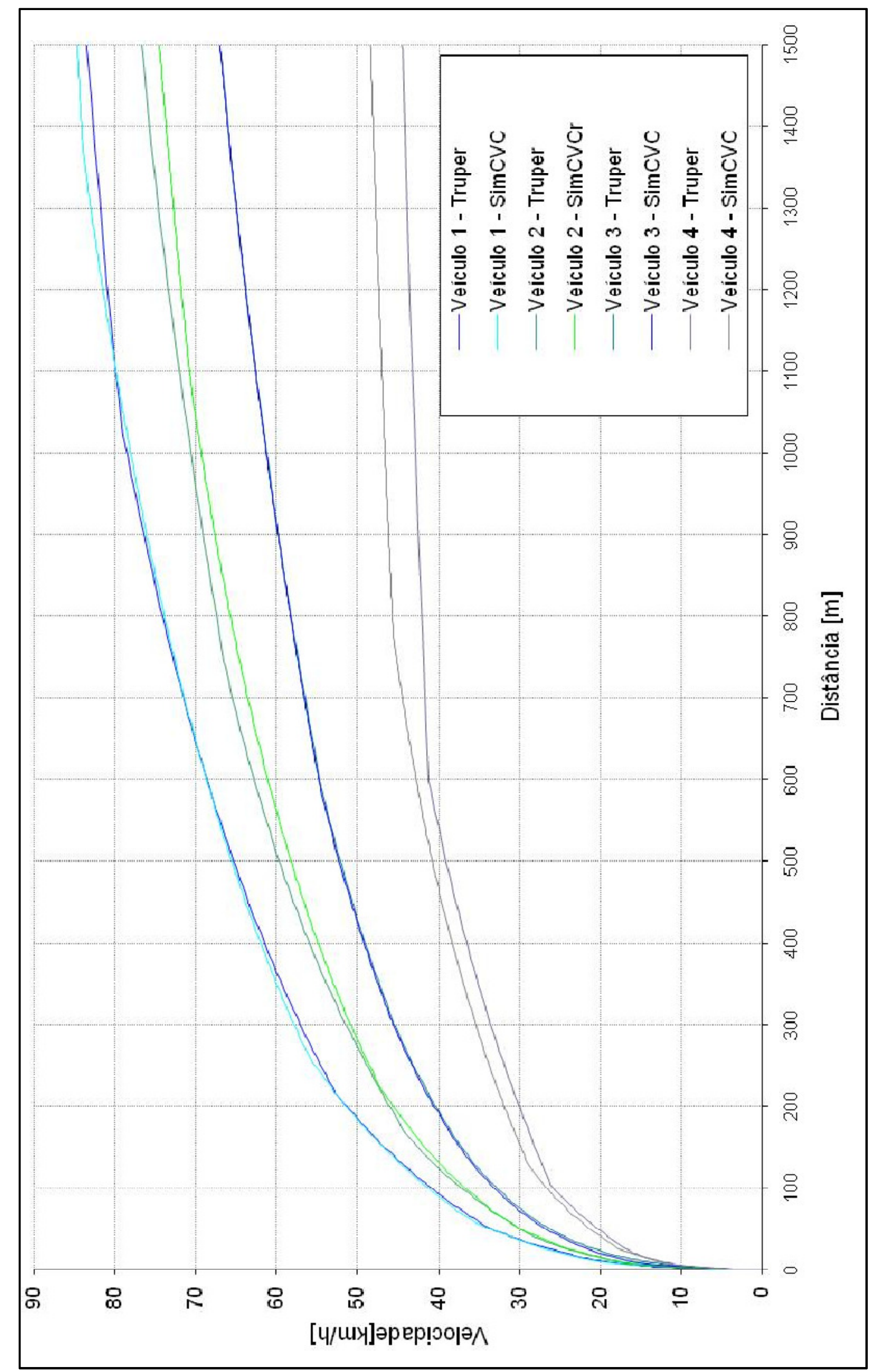

Figura 56: Perfil de velocidades: SimVC e Truper 


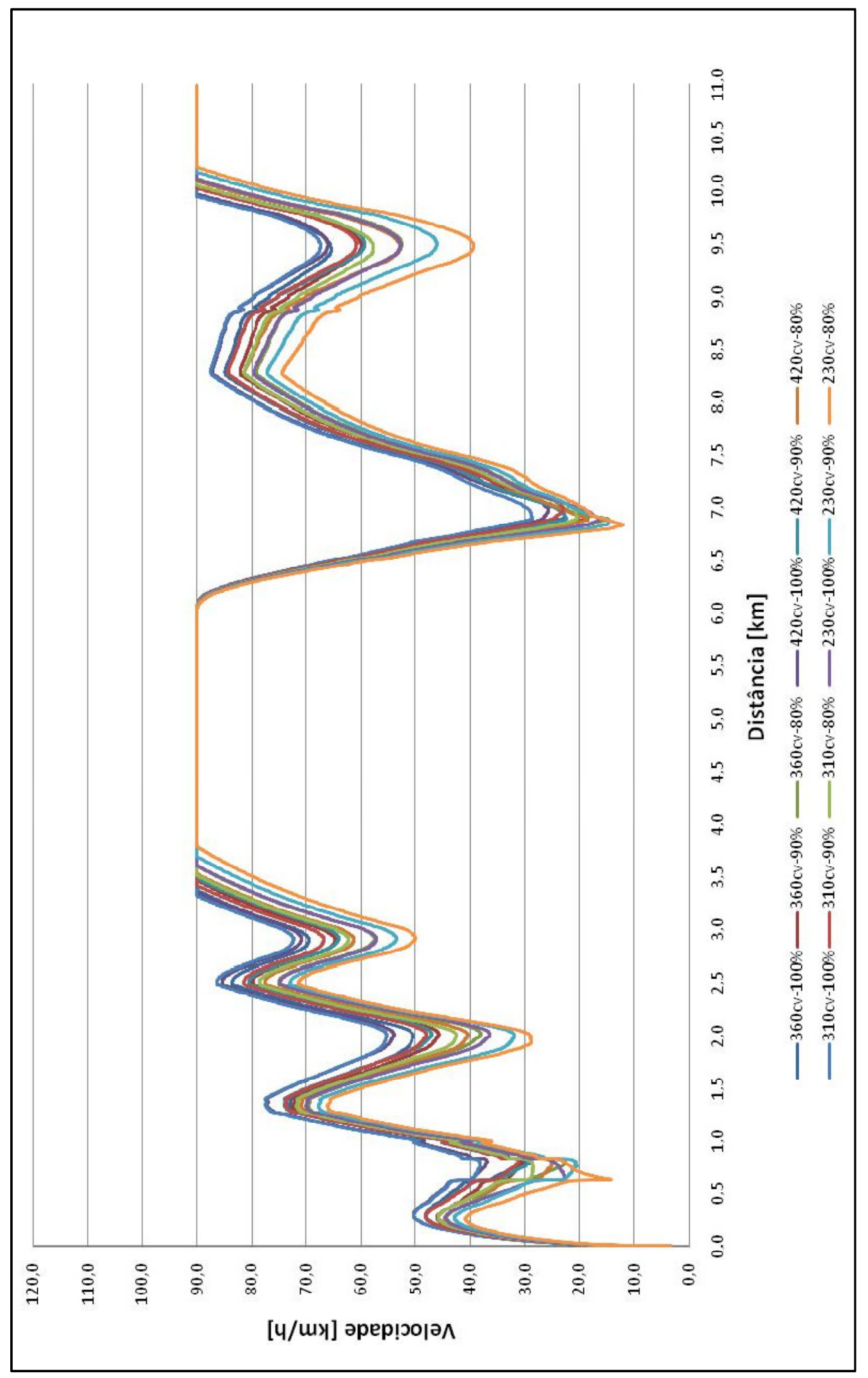

Figura 57: Perfil de velocidades: simulação (SP-310) 


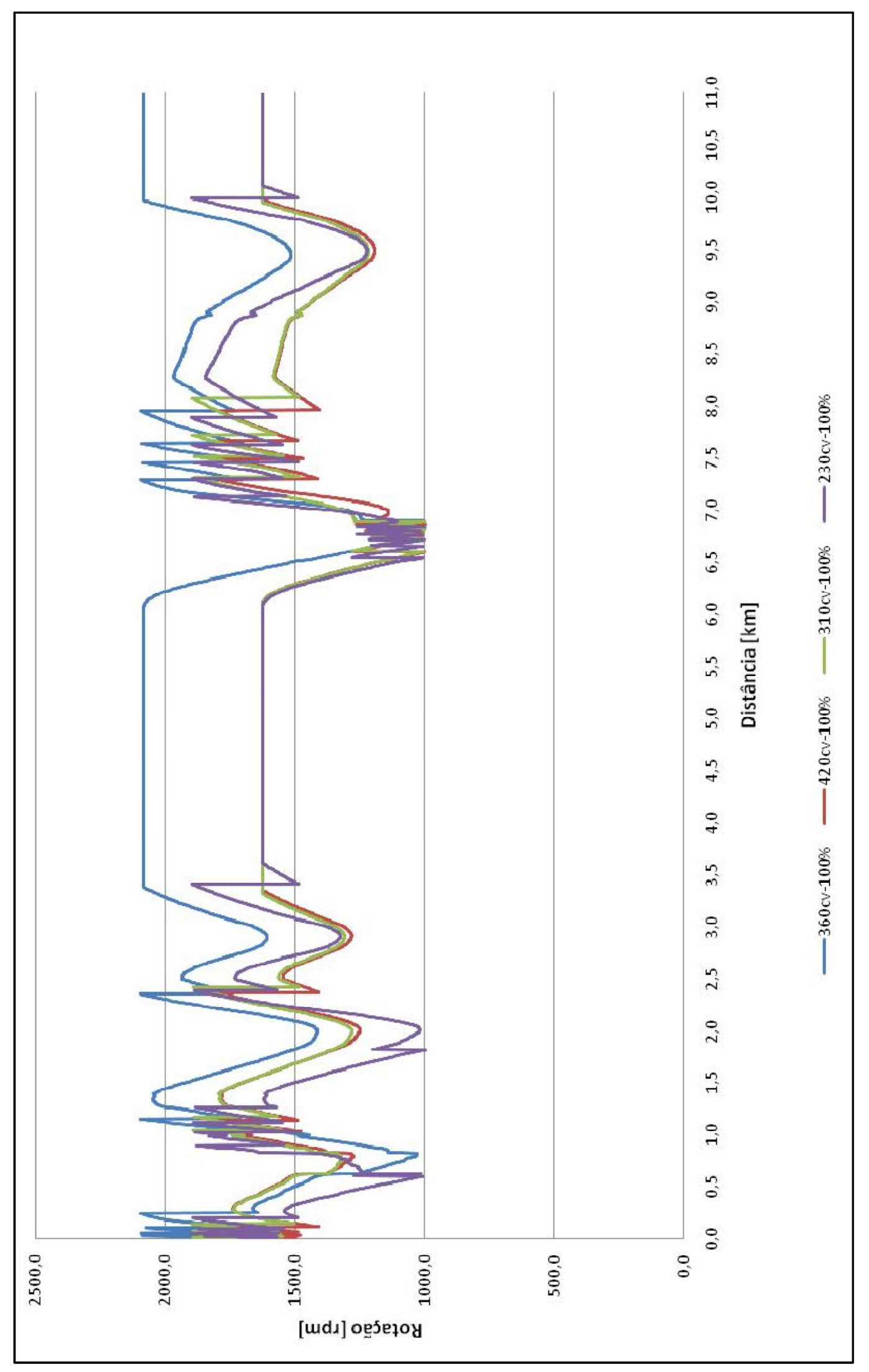

Figura 58: Perfil de rotações: simulação (SP-310) 


\section{APÊNDICE I - Tabelas}

Este apêndice apresenta tabelas propostas na literatura técnica, com valores para coeficientes de rolamento, atrito e atrito lateral, valores de área frontal de veículos rodoviários, coeficiente de arrasto, método para cálculo do diâmetro dinâmico de pneumáticos, e potência de retarders.

Tabela 16: Coeficientes de atrito (Cr) para superfícies de rodovias (Fith, 1994)

\begin{tabular}{|c|c|c|c|}
\hline \multicolumn{3}{|c|}{ Coeficientes de Rolamento } & \multirow{2}{*}{$\begin{array}{c}\text { Coeficiente de } \\
\text { Atrito } \\
\mu\end{array}$} \\
\hline Pavimento & $\begin{array}{c}\text { Condiçãa de } \\
\text { rolamento }\end{array}$ & $\mathrm{C}_{\mathrm{r}}$ & \\
\hline \multirow{3}{*}{ Concreto } & Excelente & 1,00 & 0,80 \\
\hline & Bom & 1,50 & 0,70 \\
\hline & Ruim & 2,00 & 0,60 \\
\hline \multirow{3}{*}{ Asfalto } & Bom & 1,25 & 0,60 \\
\hline & Regular & 1,75 & 0,50 \\
\hline & Ruim & 2,25 & 0,40 \\
\hline \multirow{3}{*}{ Macadame } & Bom & 1,50 & 0,55 \\
\hline & Regular & 2,25 & 0,45 \\
\hline & Ruim & 3,75 & 0,35 \\
\hline \multirow{2}{*}{ Pedrisco } & Superficial & 5,50 & 0,50 \\
\hline & Excesso & 8,50 & 0,40 \\
\hline \multirow{2}{*}{ Neve } & 2" & 2,50 & 0,20 \\
\hline & 4" & 3,75 & 0,15 \\
\hline \multirow{2}{*}{ Óleo } & Superficial & 2,50 & 0,30 \\
\hline & Excesso & 3,75 & 0,20 \\
\hline Granizo & - & 3,75 a 15,00 & 0,15 \\
\hline \multirow{2}{*}{ Areia } & Superficial & 6,00 a 15,00 & 0,15 \\
\hline & Dunas & 16,00 a 30,00 & 0,10 \\
\hline
\end{tabular}

Tabela 17: Coeficientes de atrito (C2 e C3) para pneumáticos (Fith, 1994)

\begin{tabular}{|c|c|c|}
\hline Pneumático & $\mathrm{C}_{2}$ & $\mathrm{C}_{3}$ \\
\hline Bias Ply & 0,0438 & 6,100 \\
\hline Radial & 0,0328 & 4,575 \\
\hline
\end{tabular}


Tabela 18: Coeficientes de atrito em função da velocidade

\begin{tabular}{|c|c|}
\hline $\begin{array}{c}\text { Velocidade } \\
{[\mathrm{km} / \mathrm{h}]}\end{array}$ & $\begin{array}{c}\text { Coeficiente de atrito } \\
(\mathrm{f})\end{array}$ \\
\hline 50 & 0,36 \\
\hline 60 & 0,34 \\
\hline 70 & 0,32 \\
\hline 80 & 0,31 \\
\hline 90 & 0,31 \\
\hline 100 & 0,30 \\
\hline 110 & 0,30 \\
\hline 120 & 0,29 \\
\hline 130 & 0,28 \\
\hline
\end{tabular}

Tabela 19: Fator de atrito lateral $f_{\text {máx }}$ adotado no projeto de curvas horizontais (Pereira Neto, 2007)

\begin{tabular}{|c|c|c|c|c|c|}
\hline $\begin{array}{c}\text { Velocidade } \\
{[\mathrm{km} / \mathrm{h}]}\end{array}$ & $\begin{array}{c}\text { AASHTO } \\
(\mathbf{2 0 0 4})\end{array}$ & $\begin{array}{c}\text { DNER } \\
(\mathbf{1 9 9 9 )}\end{array}$ & $\begin{array}{c}\text { TAC } \\
(\mathbf{1 9 9 9})\end{array}$ & \multicolumn{2}{|c|}{ AUSTROADS (2002) } \\
\cline { 5 - 7 } & AUTOMOVEL & CAMINHAOO \\
\hline 15 & 0,40 & - & - & - & - \\
\hline 20 & 0,35 & - & - & - & - \\
\hline 30 & 0,28 & 0,20 & - & - & - \\
\hline 40 & 0,23 & 0,18 & 0,17 & - & - \\
\hline 50 & 0,19 & 0,16 & 0,16 & 0,30 & 0,21 \\
\hline 60 & 0,17 & 0,15 & 0,15 & 0,24 & 0,17 \\
\hline 70 & 0,15 & 0,15 & 0,15 & 0,19 & 0,14 \\
\hline 80 & 0,14 & 0,14 & 0,14 & 0,16 & 0,13 \\
\hline 90 & 0,13 & 0,14 & 0,13 & 0,13 & 0,12 \\
\hline 100 & 0,12 & 0,13 & 0,12 & 0,12 & 0,12 \\
\hline 110 & 0,11 & 0,12 & 0,10 & 0,12 & 0,12 \\
\hline 120 & 0,09 & 0,11 & 0,09 & 0,11 & 0,11 \\
\hline 130 & 0,08 & - & 0,08 & - & - \\
\hline
\end{tabular}


Tabela 20: Área frontal $\left(A_{f}\right)$ para veículos (SAE J2188, 1996)

\begin{tabular}{|c|l|c|}
\hline \multicolumn{1}{|c|}{ Tipo de Veículo } & Área $\left(\mathbf{m}^{2}\right)$ \\
\hline \multirow{2}{*}{ Caminhão } & Van semi-trailer (convencional) & 10,0 \\
\hline & Van semi-trailer (largura 2,6m) & 10,7 \\
\hline & Caminhão unitário (toco) & 8,9 \\
\cline { 2 - 3 } & Cavalo mecânico (convencional) & 7,0 \\
\cline { 2 - 3 } & Cabalo mecânico & 7,9 \\
\cline { 2 - 3 } & Caminhão dump (convencional) & 6,8 \\
\hline \multirow{2}{*}{ Ônibus ou Veículo } & Ônibus intermunicipal & 7,9 \\
\cline { 2 - 3 } Recreativo & Ônibus urbano & 7,4 \\
\cline { 2 - 3 } & Ônibus escolar & 7,0 \\
\cline { 2 - 3 } & Motor-home & 7,4
\end{tabular}

Tabela 21: Coeficientes típicos de arrasto

\begin{tabular}{|c|c|c|c|}
\hline \multicolumn{2}{|c|}{ Tipo de Veículo } & $C_{d}$ & Fonte \\
\hline \multirow{8}{*}{$\begin{array}{l}\text { Carro de Pas- } \\
\text { sageiros }\end{array}$} & Convencional & 0,300 a 0,600 & Wong (1978) \\
\hline & Conversível & 0,400 a 0,650 & Wong (1978) \\
\hline & Citroen DS19 & 0,311 & Wong (1978) \\
\hline & Oldsmobile Tornado & 0,380 & Wong (1978) \\
\hline & Mercedes 300SE & 0,387 & Wong (1978) \\
\hline & Ford Falcon Futura & 0,416 & Wong (1978) \\
\hline & VW 1200 (Beetle) & 0,458 & Wong (1978) \\
\hline & Ford Mustang & 0,475 & Wong (1978) \\
\hline Motocicletas & 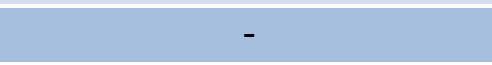 & 1,800 & Wong (1978) \\
\hline \multirow{2}{*}{ Ônibus } & Intermunicipal & 0,450 & SAE J2188 \\
\hline & Escolar & 0,550 & SAE J2188 \\
\hline \multirow{7}{*}{ Caminhões } & Unitário & 0,700 & Fith (1994) \\
\hline & Semi-reboque & 0,700 & Fith (1994) \\
\hline & Transporte de animais & 0,960 a 1,100 & SAE J2188 \\
\hline & Conteiner & 0,950 a 1,050 & SAE J2188 \\
\hline & $\begin{array}{l}\text { Sem dispositivos aerodi- } \\
\text { nâmicos no teto }\end{array}$ & 0,780 & SAE J2188 \\
\hline & $\begin{array}{l}\text { Com dispositivos aerodi- } \\
\text { nâmicos no teto }\end{array}$ & 0,640 & SAE J2188 \\
\hline & $\begin{array}{l}\text { Tratamento aerodinâmico } \\
\text { completo }\end{array}$ & 0,580 & SAE J2188 \\
\hline
\end{tabular}




\section{Diâmetro Dinâmico}

Existem dois tipos de nomenclatura utilizada pelos fabricantes para informar a característica do pneumático, exemplificados na Tabela 22.

\section{Tabela 22: Nomenclatura para pneumáticos}

\section{$A R B$}

A = Altura do pneumático $(\mathrm{cm})$

$B=$ diâmetro da roda $(\mathrm{cm})$

\subsection{R 20;}

Altura do pneumático: $10,00 \mathrm{~cm}$; Diâmetro da roda: $20 \mathrm{~cm}$.

\section{C/DRE}

$C \rightarrow$ Largura do pneumático $(\mathrm{mm})$

$D \rightarrow$ Altura do pneumático sobre a largura do pneumático (\%)

$E \rightarrow$ diâmetro do roda (pol)

\section{5/80 R 22.5}

Largura do pneumático: $275 \mathrm{~mm}$;

Altura: $0.8 \times 275 \mathrm{~mm}=220 \mathrm{~mm}$

Diâmetro da roda: 22,5 "

Neste trabalho, por falta de referências para cálculo do diâmetro dinâmico, foi adotada para este parâmetro a distância que efetivamente transfere o torque do semi-eixo ao solo. Calcula-se o diâmetro dinâmico como dobro da distância entre o eixo da roda e o pavimento.

Admite-se uma deflexão média do pneumático de dois centímetros, devido à deformação por compressão do pneumático sob efeito do peso sobre os eixos. A Figura 55 ilustra o efeito da deflexão no pneumático.

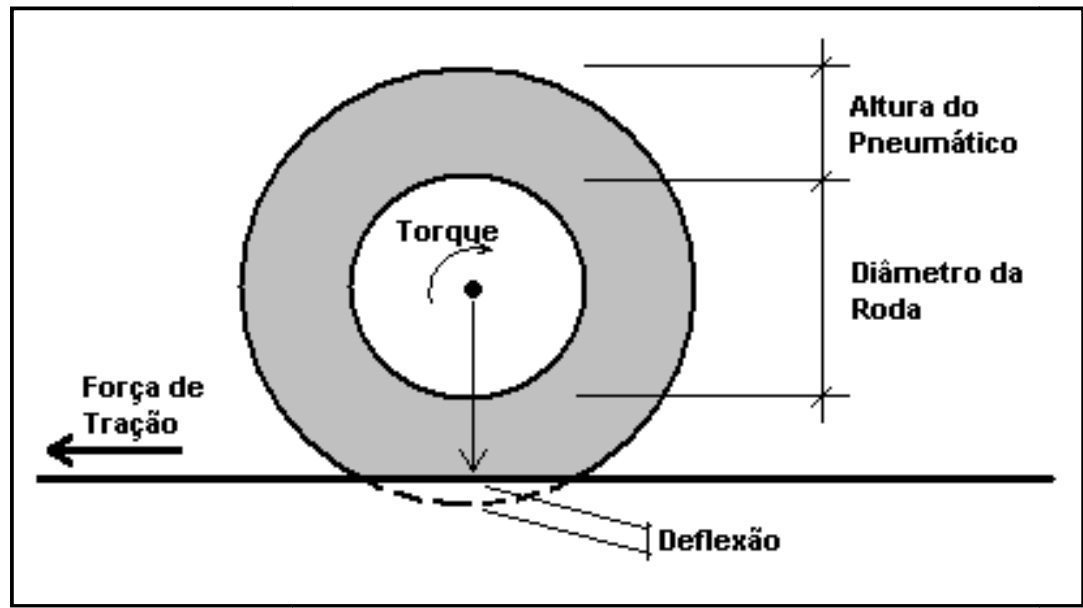

Figura 59: Diâmetro dinâmico do pneumático 
Desta forma determina-se o raio dinâmico do pneumático, somando-se o raio da roda com a altura do pneumático e subtraindo-se a deflexão:

$$
\text { Raio }_{\text {dinâmico }}=\text { Raio }_{\text {Roda }}+\text { Altura }_{\text {Pneumático }}-2 \mathrm{~cm}
$$

Ou ainda:

$$
\text { Diâmetro }_{\text {dinâmico }}=\text { Diâmetro }_{\text {Roda }}+2 . \text { Altura }_{\text {Pneunatitico }}-4 \mathrm{~cm}
$$

\section{$\underline{\text { Retarders }}$}

A utilização de retarders não é obrigatória pela legislação brasileira. A título de exemplificação, apresenta-se a Figura 56 , que mostra a potência de frenagem que diferentes tipos de retardadores de potência podem fornecer.

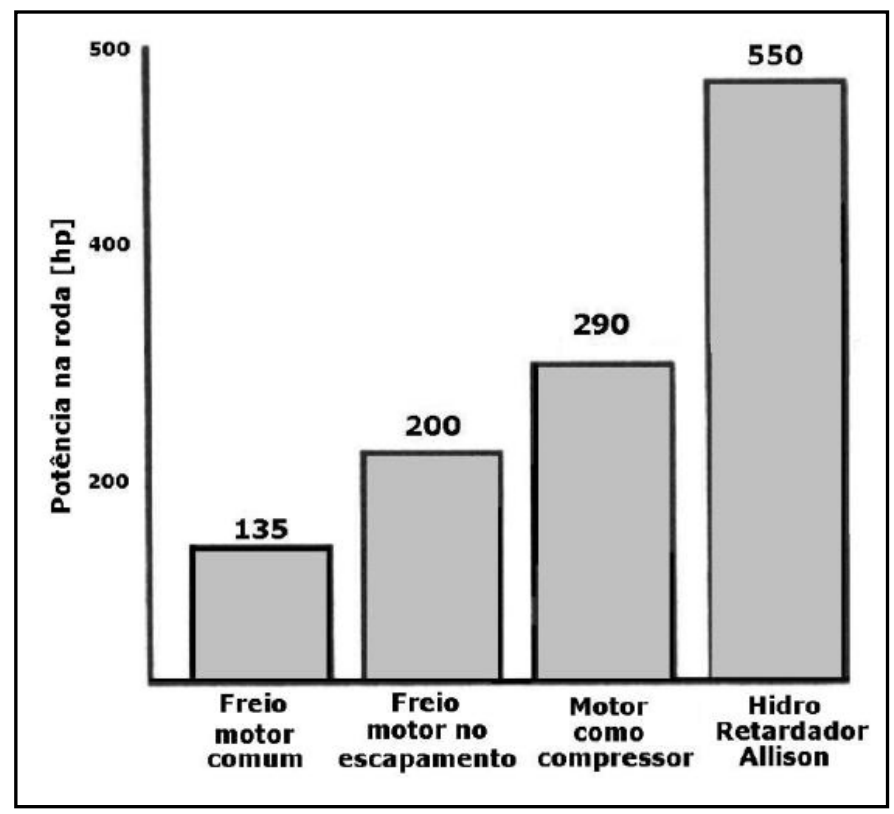

Figura 60: Freio motor e retarders (CANALE \& GUTIÉRREZ, 2005) 